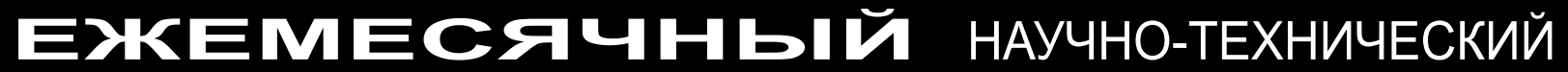
И ПРОИЗВОДСТВЕННО-ЭКОНОМИЧЕСКИЙ ЖКУРНАА
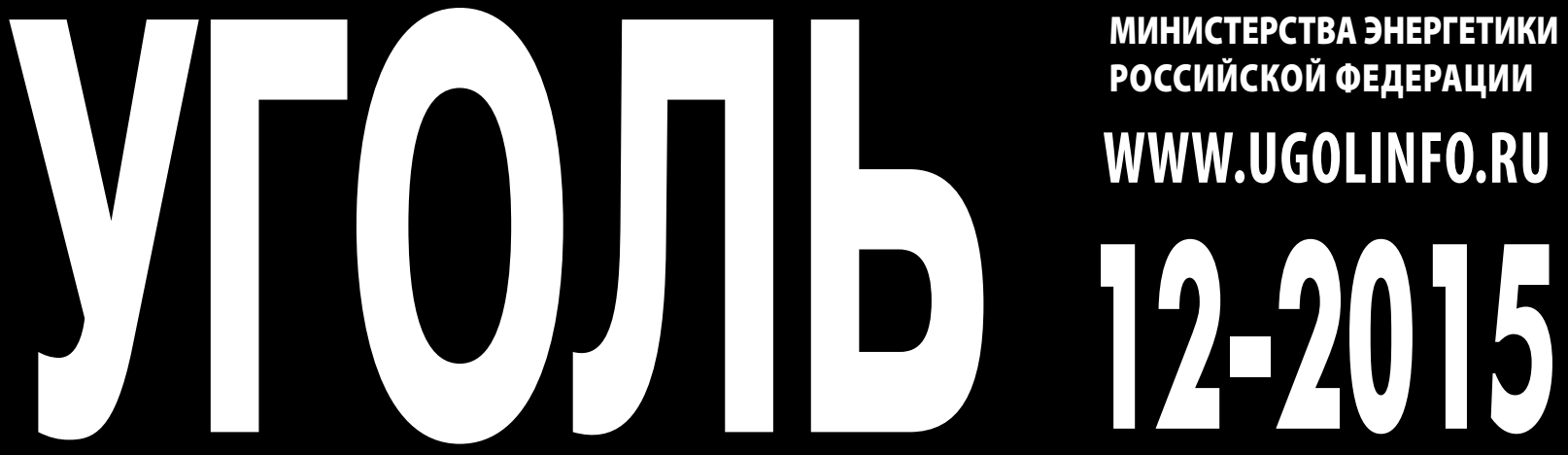

\title{
Energy Components
}

Call-центр: 88007001080

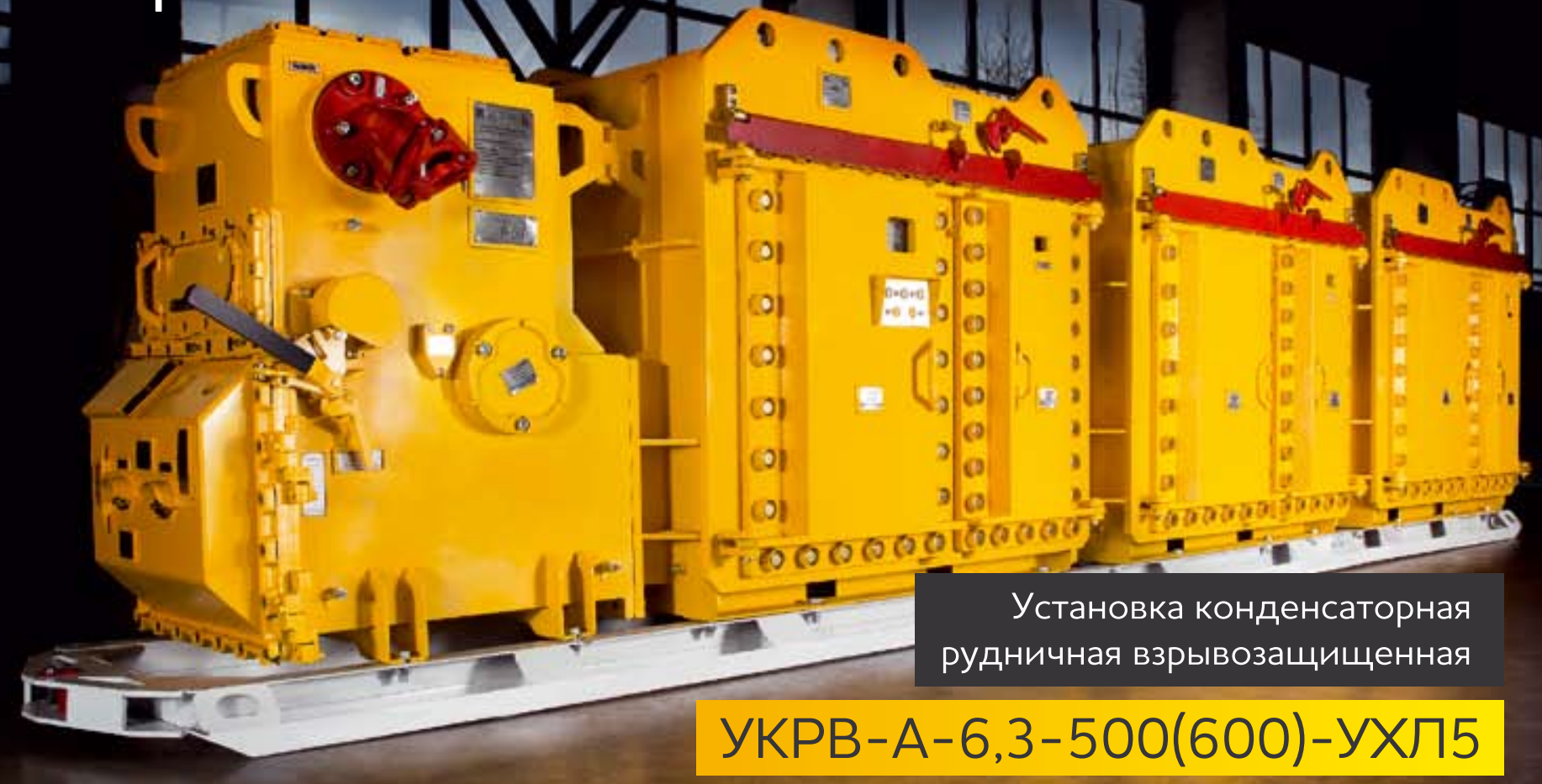

Инновационные технологии в энергетике Производство силового электрооборудования 


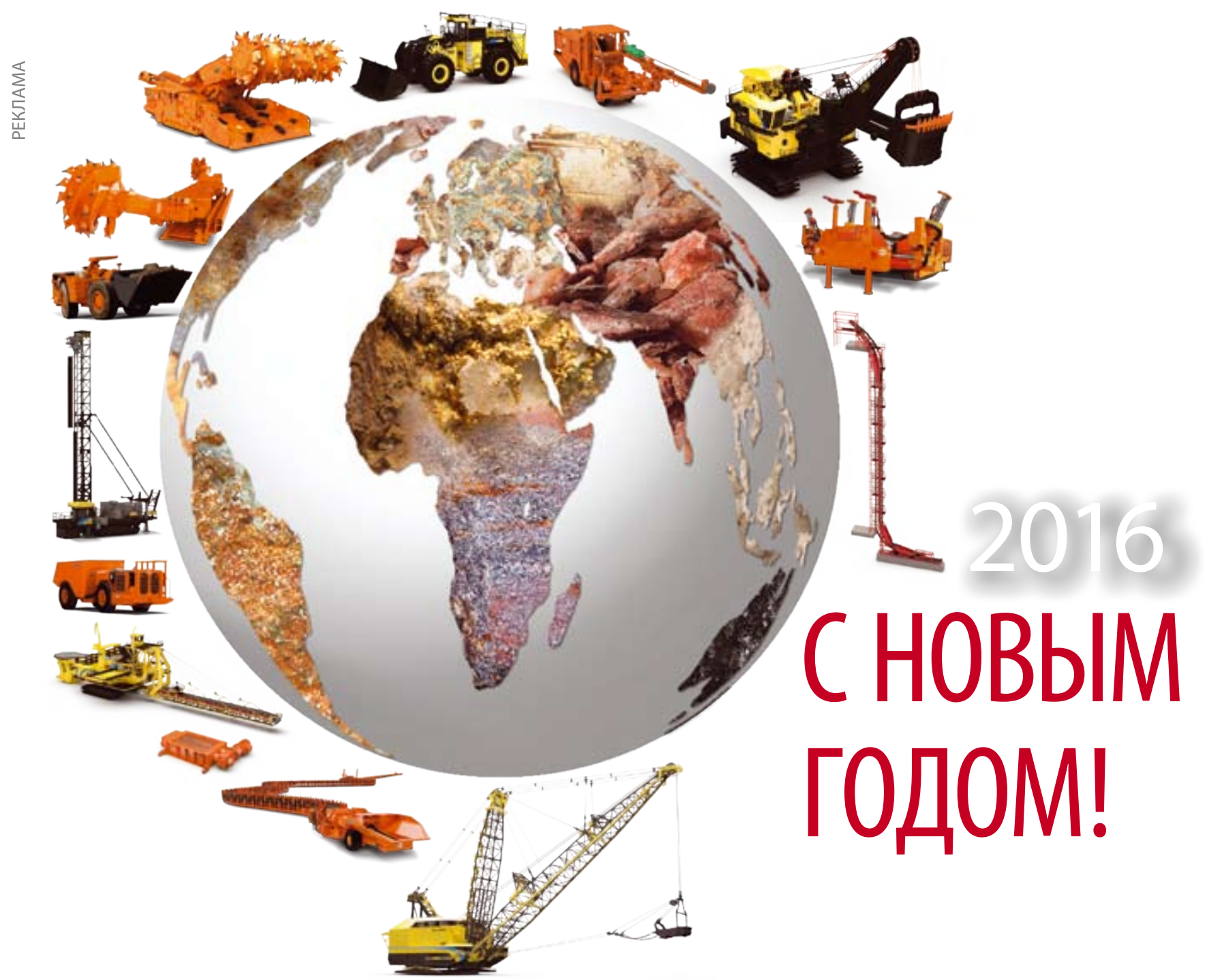

УВАЖАЕМЫЕ ПАРТНЕРЫ, КОЛЛЕГИ!

Примите наши поздравления с наступающим Новым годом и Рождеством!

Благодарим Вас за оказанное доверие и плодотворную совместную работу! Мы высоко ценим возможность выступать Вашим партнером в нелегком труде и оказывать поддержку по достижению Вашими предприятиями наивысших показателей производительности и безопасности.

Мы надеемся на дальнейшее взаимовыгодное сотрудничество и укрепление партнерских взаимоотношений! В наступающем году желаем Вам достижения и превышения производственных и финансовых показателей! Процветания, благополучия, новых проектов и перспектив, новых успехов и высоких результатов!

Крепкого здоровья, семейного благополучия и счастья Вам и Вашим близким!

С наилучшими пожеланиями,

коллектив компании 000 «Джой Глобал»

\section{P\&H}

ООО «ДЖОЙ гЛОБАЛ»

653212, Кемеровская обл., Прокопьевский р-н,

пос. Калачево, ул. Мира, 15

Тел./факс: (3846) 64-22-00, 64-22-01

ОФИС В МОСКВЕ

Тел./факс: (495) 969-22-78, 663-37-87

ОФИС В КЕМЕРОВО

Тел./факс: (3842) 51-68-10, 51-65-83

e-mail: joykuzbass@joyglobal.com 
Главный редактор ЯНОВСКИЙ А.Б.

Заместитель министра энергетики

Российской Федерации,

доктор экон. наук

Зам. главного редактора

ТАРАЗАНОВ И.Г.

Генеральный директор

ООО «Редакция журнала «Уголь»,

горный инженер, чл.-корр. РАЭ

\section{РЕДАКЦИОННАЯ КОЛЛЕГИЯ}

AРТЕМЬEВ В.Б, доктор теХн. наук

БАСКАКОВ В.П., канд. Техн. наук

ВЕРЖАНСКИЙ А.П.,

доктор техн. наук, профессор

ГАЛКИН В.А., доктор техн. наук, профессор

ЗАЙДЕНВАРГ В.Е.,

доктор техн. наук, професссор

КОВАЛЕВ В.А.,

доктор техн. наук, профессор

КОВАЛЬЧУК А.Б.,

доктор техн. наук, профессор

КОРЧАК А.В., доктор техн. наук, профессор

ЛИТВИНЕНКО В.С.,

доктор техн. наук, профессор

МАЛЫШЕВ Ю.Н., академИк РАН,

доктор техн. наук, профессор

МОСКАЛЕНКО И.В., Канд. ПЕХН. НауК

МОХНАЧУК И.И., КаНӘ. эКОН. наУК

МОЧАЛЬНИКОВ С.В., Канд. эКОН. Наук

ПЕТРОВ И.В., доктор экон. наук, профессор

ПОПОВ В.Н., доктор экон. наук, профессор

ПОТАПОВ В.П.,

доктор техн. наук, профессор

ПУЧКОВ Л.А., чл.-Корр. РАН,

доктор техн. наук, профессор

РОЖкОВ А.А., доктор экон. наук, профессор

РЫБАК Л.В., доктор экон. наук, профессор

СКРЫЛЬ А.И., горный инженер

СУСЛОВ В.И., чл.-корр. РАН, Әоктор экон.

наук, профессор

ТАТАРКИН А.И., академик РАН,

доктор экон. наук, профессор

ЩАДОВ В.М., доктор техн. наук, профессор

ЩУКИН В.К., доктор экон. наук

ЯКОВЛЕВ Д.В., доктор техн. наук, профессор

Иностранные члены редколлегии

Проф. Гюнтер АПЕЛЬ,

доктор техн. наук, Германия

Проф. Карстен ДРЕБЕНШТЕДТ,

доктор техн. наук, Германия

Проф. Юзеф дУБИНьСКИ,

доктор техн. наук, чл.-корр. Польской

академии наук, Польша

Сергей НИКИШИЧЕВ, FIMMM,

канд. экон. наук, Великобритания, Россия,

страны СНГ и Монголия

Проф. Любен ТОТЕВ,

доктор наук, Болгария

๑) «Уголь», 2015

\section{ЕЖЕМЕСЯЧНЫЙ НАУЧНО-ТЕХНИЧЕСКИЙ} И ПРОИЗВОДСТВЕННО-ЭКОНОМИЧЕСКИЙ ЖУРНАЛ

Основан в октябре 1925 года

УЧРЕДИТЕЛИ

МИНИСТЕРСТВО ЭНЕРГЕТИКИ

РОССИЙСКОЙ ФЕДЕРАЦИИ

РЕДАКЦИЯ ЖУРНАЛА «УГОЛЬ»

ДЕКАБРЬ

$12-2015 / 1077 /$

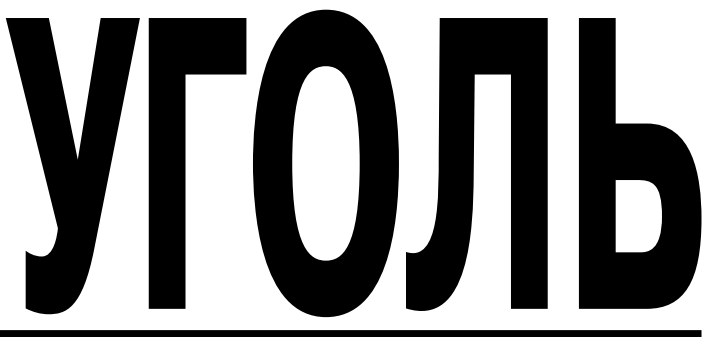

СОДЕРЖАНИЕ

\section{ОТКРЫТЫЕ РАБОТЫ}

Глинина 0.И.

II Международная научно-практическая конференция

«0ткрытые горные работы в XXI веке»: итоги работы

Щукин В. К., Зыкалин А. В.

Особенности буровзрывных работ на угольных разрезах

Т00 «Богатырь Комир»

Матва С. В., Кокин С. В., Литвин Ю. И., Протасов С. И., Корнев Г. Н., Федотенко В. С.

Совершенствование способов буровзрывной подготовки пород

на предприятиях $0 \mathrm{A0}$ «УК «Кузбассразрезуголь»

Репин Н. Я., Ташкинов А. С., Колесников В. Ф., Протасов С. И., Литвин О.И.

Кафедре «0ткрытые горные работы» КузГТУ — 60 лет!

Добровольский А. И., Галимьянов А. А., Шевкун Е. Б., Лещинский А. В.

Совместная разработка сближенных пологих каменноугольных пластов

в разнопрочных и мерзлых вмещающих породах

PEГИОНЫ

Курбанов Н. Х., Рафиенко В. А.

Развитие угледобывающих предприятий Дальнего Востока

(за период с 1965 по 2015 гг.)

Байсаров Р.С.

Концептуальные подходы к стратегии освоения Элегестского месторождения

Улуг-Хемского угольного бассейна Республики Тыва

\section{ОРГАНИЗАЦИЯ ПРОИЗВОДСТВА}

Ошаров А. В.

Организационные и технологические решения

по обеспечению жизнеспособности разреза «Изыхский» 49

\section{ЭКОНОМИКА}

Новоселов С. В.

Энергетическая стратегия России ЭС-2030, ее приоритеты и новые ответы внешним вызовам (аспект специфики стратегий региональных ТЭК)

БЕЗОПАСНОСТЬ

Баркалова Н. Ю.

Защита органов дыхания работников добывающих предприятий 56

PECУPCЫ

Садов А. П., Костеренко В. Н., Тайлаков О. В., Уткаев Е. А., Застрелов Д. Н., Смыслов А. И.

Опыт использования вентиляционного метана в качестве дополнительного

топлива для двигателей внутреннего сгорания 
ООО «РЕДАКЦИЯ ЖУРНАЛА «УГОЛЬ»

119049, г. Москва,

Ленинский проспект, д. 6, стр. 3, офис Г-136

Тел./факс: (499) 230-25-50

E-mail: ugol1925@mail.ru

E-mail:ugol@land.ru

Генеральный Әиректор

Игорь ТАРАЗАНОВ

Ведущий редактор

Ольга ГЛИНИНА

Научный редактор

Ирина КОЛОБОВА

Менеджер

ИрИна ТАРАЗАНОВА

Ведущий специалист

Валентина ВОЛКОВА

ЖУРНАЛ ЗАРЕГИСТРИРОВАН

Федеральной службой по надзору

в сфере связи и массовых коммуникаций.

Свидетельство о регистрации

средства массовой информации

ПИ № ФС77-34734 от 25.12.2008 г

ЖУРНАЛ ВКЛЮЧЕН

в Перечень ведущих рецензируемых научных журналов и изданий, в которых должны быть опубликованы основные научные результаты диссертаций на соискание ученых степеней доктора и кандидата наук, утвержденный решением ВАК Минобразования и науки РФ

\section{ЖУРНАЛ ПРЕДСТАВЛЕН}

В Интернете на вэб-сайте

\section{www.ugolinfo.ru www.ugol.info}

и на отраслевом портале «РОССИЙСКИЙ УгОЛЬ»

\section{www.rosugol.ru}

информационный партнер журнала - УГОЛЬНЫЙ ПОРТАЛ

\section{www.coal.dp.ua}

НАД НОМЕРОМ РАБОТАЛИ:

Ведущий редактор О.И. ГЛИНИНА

Научный редактор И.М. КОЛОБОВА

Корректор А.М. ЛЕЙБОВИЧ

Компьютерная верстка Н.И. БРАНДЕЛИС

Подписано в печать 01.12.2015.

Формат 60х90 1/8.

Бумага мелованная.

Печать офсетная.

Усл. печ. л. 11,0+ обложка.

Тираж 4700 экз.

Тираж эл. версии 1600 экз.

Общий тираж 6300 экз.

\section{Отпечатано:}

ООО «РОЛИКС»

117218, г. Москва, ул. Кржижановского, 31

Тел.: (495) 661-46-22;

www.roliksprint.ru

Заказ № 20054

๑) ЖУРНАЛ «УГОЛЬ», 2015

\section{ПЕРЕРАБОТКА УГЛЯ}

Антипенко Л. А.

К вопросу о современных технологиях переработки и обогащения угля 68

\section{ЭКОЛОГИя}

Ефимов В. И., Сидоров Р. В., Корчагина Т. В.

Образование отходов производства от предприятий угольной отрасли

на территории Кемеровской области

\section{ВЫСТАВКИ}

0бозначены векторы развития российской горнорудной промышленности 77

Итоги VI Международной конференции «Железнодорожные перевозки горно-металлургических грузов РФ» 78

\section{ИНФОРМАЦИЯ}

Перечень статей, опубликованных в журнале «Уголь» в 2015 году 81 НЕКРОЛОГИ

Липилин Степан Захарович (09.07.1915 - 12.11.2015 гг.) 87

Дьяков Юрий Иванович (30.03.1942 - 31.10.2015 гг.) 88

\section{Список реклам}

\begin{tabular}{|c|c|c|c|}
\hline EXC & 1-я обл. & BARTEC GmbH & 43 \\
\hline JoyGlobal & 2-я обл. & Компания ДЭП & 54 \\
\hline СУЭК & 3-я обл. & НПП «Завод МдУ» & 60 \\
\hline Корпорация СЕТСО & 4-я обл. & WEIR Minerals & 66 \\
\hline СПК-СтыК & 17 & www. cargo-report. ru & 79 \\
\hline МК «Ильма» & 32 & Вст Евразийский & \\
\hline ХК «СДС-Уголь» & 32 & горно-геологический форум & 80 \\
\hline
\end{tabular}

Подписные индексы:

— Каталог «Газеты. Журналы» Роспечати

71000, 71736, 73422
— Объединенный каталог «Пресса России» $\mathbf{8 7 7 1 7 , ~ 8 7 7 7 6 , ~} \mathbf{3 8 7 7 1 7}$

- Каталог «Почта России» - 11538 
UGOL' / RUSSIAN COAL JOURNAL UGOL' JOURNAL EDITORIAL BOARD

Chief Editor

YANOVSKY A.B., Dr. (Economic), Ph.D. (Engineering), Deputy Minister of Energy of the Russian Federation, Moscow, 107996, Russian Federation

\section{Deputy Chief Editor}

TARAZANOV I.G., Mining Engineer, Moscow,

119049, Russian Federation

Members of the editorial council:

ARTEMYEV V.B., Dr. (Engineering),

Moscow, 115054, Russian Federation

BASKAKOV V.P., Ph. D. (Engineering),

Kemerovo, 650002, Russian Federation

VERZHANSKY A.P., Dr. (Engineering), Prof.,

Moscow, 125009, Russian Federation

GALKIN V.A., Dr. (Engineering), Prof.,

Chelyabinsk, 454048, Russian Federation

ZAYDENVARG V.E., Dr. (Engineering), Prof,

Moscow, 119019, Russian Federation

KOVALEV V.A., Dr. (Engineering), Prof.,

Kemerovo, 650000, Russian Federation

KOVALCHUK A.B., Dr. (Engineering), Prof.,

Moscow, 119019, Russian Federation

KORCHAK A.V., Dr. (Engineering), Prof.,

Moscow, 119049, Russian Federation

LITVINENKO V.S., Dr. (Engineering), Prof.,

Saint Petersburg, 199106, Russian Federation

MALYSHEV Yu.N., Dr. (Engineering), Prof.,

Acad. of the RAS, Moscow, 125009, Russian

Federation

MOSKALENKO I.V., Ph.D. (Engineering),

Kemerovo, 650054, Russian Federation

MOKHNACHUK I.I., Ph.D. (Economic),

Moscow, 109004, Russian Federation

MOCHALNIKOV S.V., Ph.D. (Economic),

Moscow, 107996, Russian Federation

PETROV I.V., Dr. (Economic), Prof,

Moscow, 119071, Russian Federation

POPOV V.N., Dr. (Economic), Prof.,

Moscow, 119071, Russian Federation

POTAPOV V.P., Dr. (Engineering), Prof.,

Kemerovo, 650025, Russian Federation

PUCHKOV L.A., Dr. (Engineering), Prof.,

Corresp. Member of the RAS, Moscow, 119049,

Russian Federation

ROZHKOV A.A., Dr. (Economic), Prof.,

Moscow, 119071, Russian Federation

RYBAK L.V., Dr. (Economic), Prof.,

Moscow, 119034, Russian Federation

SKRYL A.I., Mining Engineer,

Moscow, 119049, Russian Federation

SUSLOV V.I., Dr. (Economic), Prof., Corresp.

Member of the RAS, Novosibirsk, 630090, Russian

Federation

TATARKIN A.I., Dr. (Economic), Prof., Acad.

of the RAS, Ekaterinburg, 620014, Russian Federation

SHCHADOV V.M., Dr. (Engineering), Prof.,

Moscow, 119034, Russian Federation

SHCHUKIN V.K., Dr. (Economic),

Ekibastuz, 141209, Republic of Kazakhstan

YAKOVLEV D.V., Dr. (Engineering), Prof.,

Saint Petersburg, 199106, Russian Federation

Foreign members of the editorial council:

Prof. Guenther APEL, Dr.-Ing.

Essen, 45307, Germany

Prof. Carsten DREBENSTEDT, Dr. (Engineering),

Freiberg, 09596, Germany

Prof. Jozef DUBINSKI, Dr. (Engineering), Corresp.

Member PAS, Katowice, 40-166, Poland

Sergey NIKISHICHEV, FIMMM, Ph.D. (Economic),

Moscow, 125047, Russian Federation

Prof. Luben TOTEV, Dr., Sofia, 1700, Bulgaria

Ugol' Journal Edition LLC

Leninsky Prospekt, 6 ,

building 3 , office $\mathrm{G}-136$

Moscow, 119049, Russian Federation

Tel/fax: +7 (499) 230-2550

E-mail:ugol1925@mail.ru

www.ugolinfo.ru

๑ Ugol' - Russian Coal Journal, 2015
MONTHLY JOURNAL, THAT DEALS WITH SCIENTIFIC, TECHNICAL, INDUSTRIAL AND ECONOMIC TOPICS

Established in October 1925

FOUNDERS

MINISTRY OF ENERGY

THE RUSSIAN FEDERATION,

UGOL' JOURNAL EDITION LLC

DECEMBER

$12^{\prime} 2015$

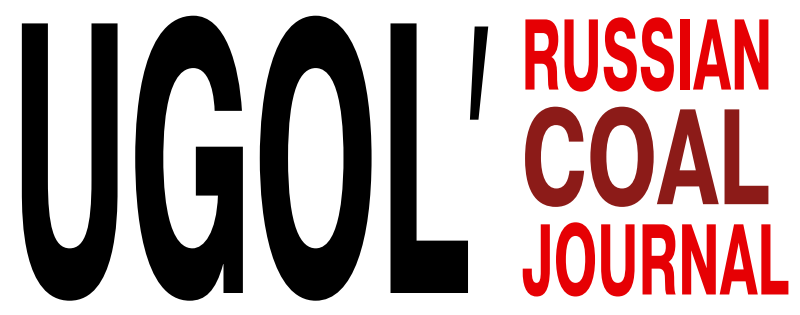

CONTENT

SURFACE MINING

Glinina 0.1.

II International theoretical and practical conference "Surface mining in XXI century":

Summary record

Schukin V.K., Zykalin A.V.

Specific features of drilling and blasting operations at the coal strip mines of "Bogatyr Komir" LLP _ 18

Matva S.V., Kokin S.V., Litvin Yu.I., Protasov S.I., Kornev G.N., Fedotenko V.S

Improvement of blast-hole drilling methods for rock mass preparation at the enterprises

of "UK Kuzbassrazrezugol" OJSC

Repin N.Ya., Tashkinov A.C., Kolesnikov V.F., Protasov C.I., Litvin 0.I.

Surface Mining Department of KuzGTU — 60 years!

Dobrovolsky A.I., Galimyanov A.A., Shevkun E.B., Leschinsky A.V.

Development of a group of coal seams with gross explosive loosening overburden 34

REGIONS

Kurbanov N.Kh., Rafienko V.A.

Development of coal producers of the Far East / Dal'niy Vostok Region (1965-2015)

Baysarov R.S.

The conceptual approaches to the Elegestsky field of Ulugh-Khem coal basin in the Republic

of Tyva development strategy

\section{PRODUCTION SETAP}

Osharov A.V.

Organizational and technological solutions for "Izykhskiy" open-pit mine sustainability assurance _

ECONOMIC OF MINING

Novoselov S.V.

Energy strategy of Russia — ES-2030, it priorities and new responses

to the external challenges (specifics of regional fuel and energy sector strategies)

SAFETY

Barkalova N.Yu.

Respiratory protection for mining workers 56

RESOURCES

Sadov A.P., Kosterenko V.N., Tailakov 0.V., Utkaev E.A., Zastrelov D.N., Smyslov A.I.

Experience of vent air methane use as supplementary fuel for internal-combustion engines 61

COAL PREPARATION

Antipenko L.A.

On the Issue of Advanced Coal Processing and Beneficiation Technologies 68 ECOLOGY

Efimov V.I., Sidorov R.V., Korchagina T.V.

Generation of coal mining production wastes in the Kemerovo Region territory 73 EXHIBITIONS

The vectors of Russian ore mining industry development are defined 77

The results of VI International Conference "Rail deliveries of mining and metallurgical cargo in RF" _ 78 INFORMATION

Index of articles published in Ugol' — Russian Coal Journal in 2015 81

NECROLOGUE

Lipilin Stepan Zakharovich (09.07.1915 - 12.11.2015)

Dyakov Yury Ivanovich (30.03.1942 - 31.10.2015) 88 


\section{II Международная научно-практическая конференция «0ткрытые горные работы в XXI веке»}

\section{По итогам работы второй международной научно-практической конференции}

С 1 по 3 октября в Красноярском выставочно-деловом центре "Сибирь» проходила II Международная научно-практическая конференция «Omкрытые горные работы в XXI веке». Организаторами мероприятия выступили: $A O$ "Сибирская угольная энергетическая компания" (СУЭК), Институт проблем комплексного освоения недр Российской академии наук (ИПКОН РАН) и Научно-исследовательский институт открытых горных работ (НИИОГР).

На масштабный горняцкий форум приехали более 300 руководителей, технических директоров и инженеров ведущих добывающих компаний из России, Казахстана, Польши, Японии, США, Великобритании и других стран, представителей компаний-изготовителей и дилеров горного и горнотранспортного оборудования, ученых крупнейших исследовательских институтов в области горного дела, преподавателей профильных вузов, представителей федеральных органов в сфере экологического и технологического надзора.

Красноярский край не случайно стал площадкой для обсуждения современных тенденций, новых технических и технологических решений, обмена передовым опытом в сфере открытых горных работ. Регион занимает одно из ведущих в России мест по запасам минеральных ресурсов и полезных ископаемых. В его недрах встречаются нефть, железные руды, цветные и редкие металлы. Особое место в экономике края занимает угольная промышленность. Здесь добывается каждая десятая тонна российского угля.

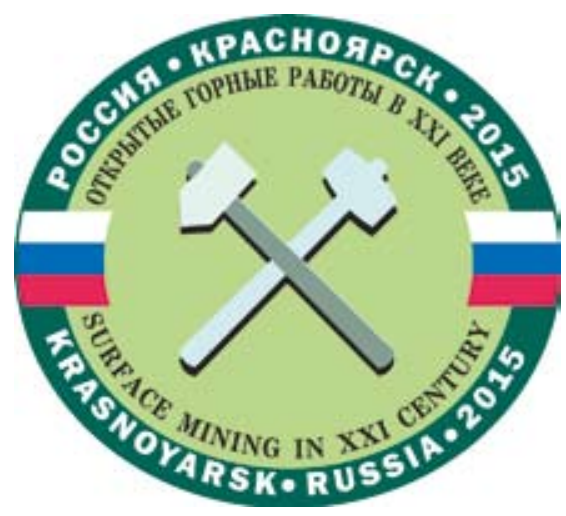

\section{НА БЛАГО ВСЕЙ УГОЛЬНОЙ ОТРАСЛИ РОССИИ}

Гостей и участников от имени организаторов конференции приветствовал исполнительный директор АО «СУЭК-Красноярск» Андрей Витальевич Федоров. Он подчеркнул, что главной задачей конференции является объединение сообщества горных инженеров, работников науки и производителей горного оборудования для выработки совместной позиции в развитии горной промышленности открытого способа разработки. «Этот союз поможет нам эффрективно работать дальше с требованиями безопасности, с соблюдением всех требований экологии, которые становятся все жестче» - отметил А.В. Федоров.

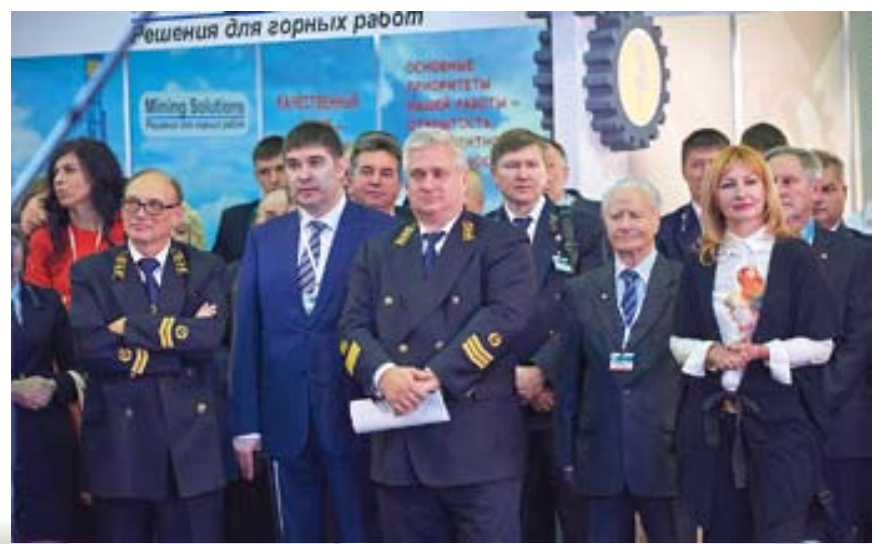

Материалы подготовила Ольга Глинина

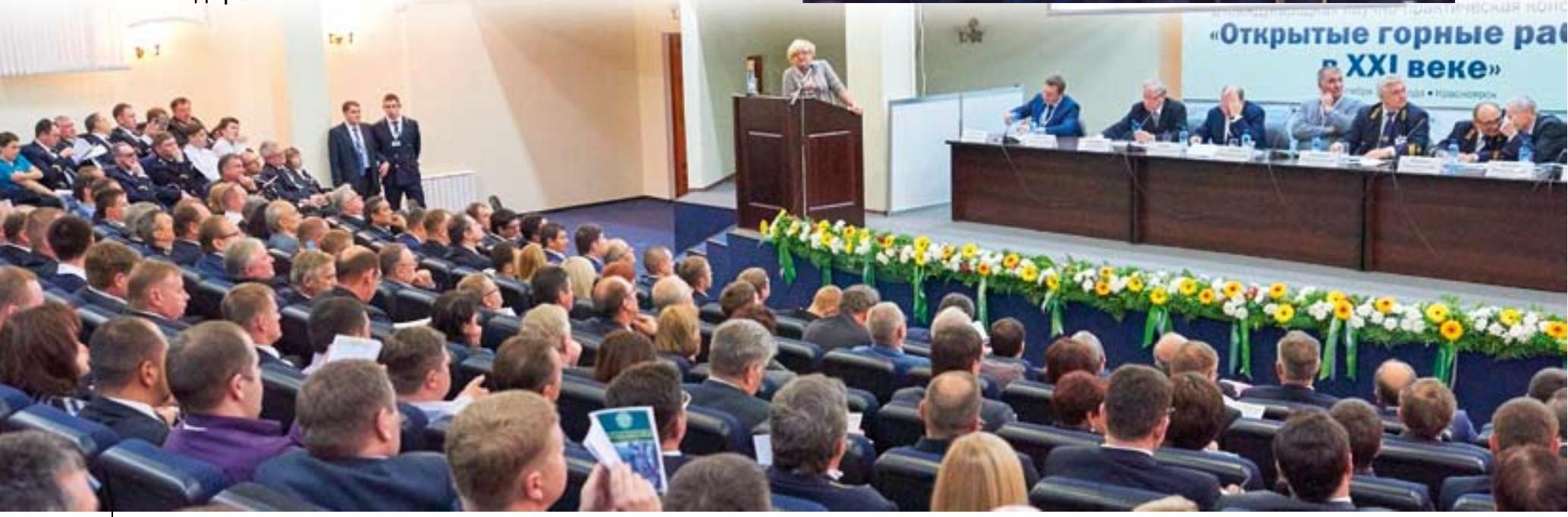

4 ДЕКАБРЬ, 2015, “УГОЛЬ" 
Директор Департамента угольной и торфяной промышленности Минэнерго России Сергей Викторович Мочальников от лича министерства и от себя лично приветствовал участников и гостей конференции: «Надеюсь, что все лучшие доклады будут опубликованы и использованы на благо всей угольной

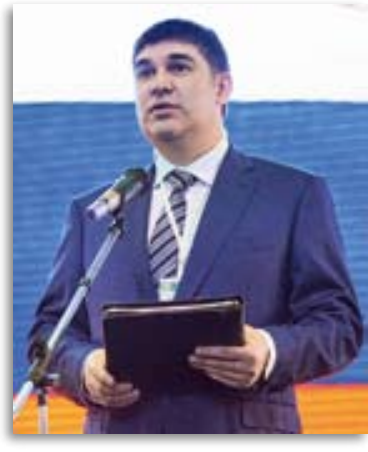
отрасли Российской Федерации для того, чтобы угля добывали больше, чтобы травматизм был меньше, чтобы угольная промышленность, как и прежде, оставалась на достойном уровне в энергетическом балансе страны'».

Важность подобной конференции и для угольной отрасли, и для Красноярского края отметила в приветственном слове и министр природных ресурсов и экологии региона Елена Владимировна Вавилова: «Тех ресурсов, которыесегодняестьв крае, хватит на многие сотни лет. Причем этот потенциал позволяет обеспечивать энергетическим

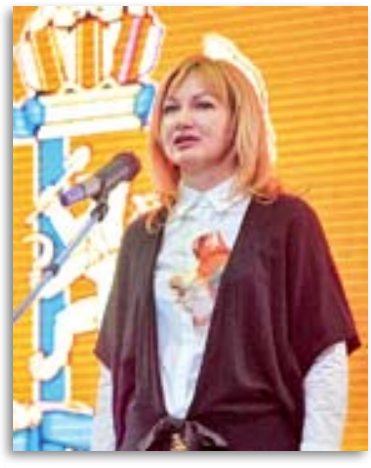
сырьем и наш регион, и другие субъекты Российской Федерачии. Тема именно открытых горных работ для края тоже не праздная, этот способ добычи является доминирующим. Предприятия крупнейшей угледобывающей компании СУЭК - это гордость Красноярского края и по культуре организации работ, и по технологиям, которые

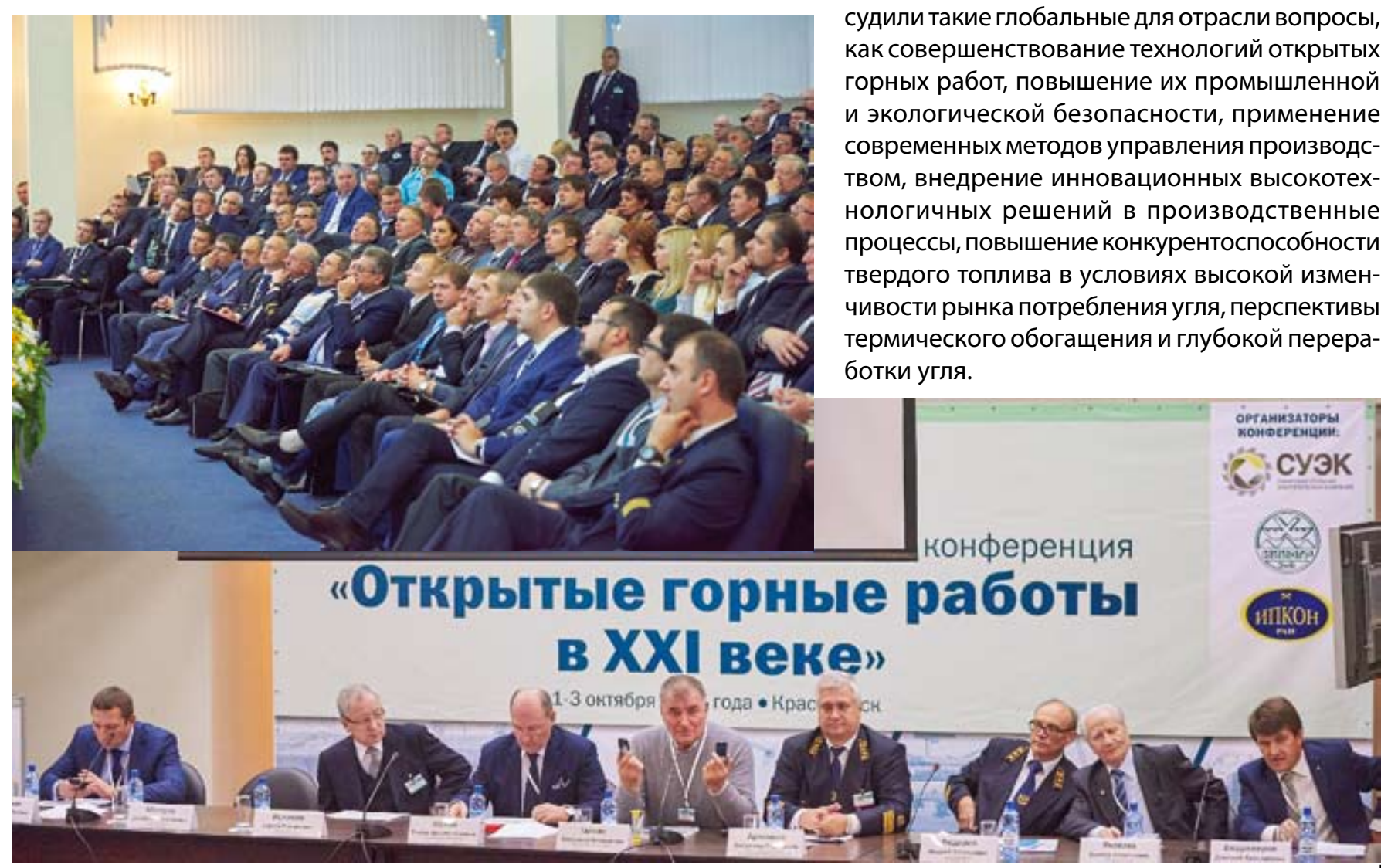

здесь применяются, и по профессионализму команды. Компания является социально значимой и сочиально ответственной, поэтому и внимание властей к ней огромно и взаимно. Наэтой конференции по-новому в действующих экономических условиях будут звучать вопросы не только технологии, организации и качества сервисных услуг, кадрового потенциала, но и импортозамещения. Желаю всем успехов. Уверена, конференция даст огромный толчок для будущего развития и СУЭК, и горнодобывающей отрасли России».

Как сказал в своем приветственном слове заместитель генерального директора - директор по производственным операциям АО «СУЭК» Владимир Борисович Артемьев: «В Красноярск съехались самые известные действующие «командиры» горного дела, которые вносят вклад в развитие не только своих предприятий, но и горнодобывающей отрасли всей страны. В силу опыта и профессионализма они очень тонко слышат собеседников, очень грамотно выражают свою мысль, так что каждый, кто уедет с этой конференции, станет более умело, эффективно работать с природой, с недрами. Для СУЭК сегодняшний горняцкий форум - очень важное событие, это работа для ума, обмен опытом».

В течение двух дней на различных площадках Горного форума с докладами выступило около 150 специалистов угледобывающих предприятий и представителей научного сообщества. В ходе конференции участники - руководители Сибирской угольной энергетической компании и других крупнейших угледобывающих компаний, таких как ОАО «Востсибуголь» из Иркутской области, ТОО «Богатырь Комир» из Казахстана, партнеры угольщиков - ООО «РУСАЛ ИТЦ», ОАО «ВИСТ Групп», представители Российской академии наук, научно-исследовательских институтов об- судили такие глобальные для отрасли вопросы, как совершенствование технологий открытых твом, внедрение инновационных высокотехнологичных решений в производственные процессы, повышение конкурентоспособности измен ктивы о тки угля. 

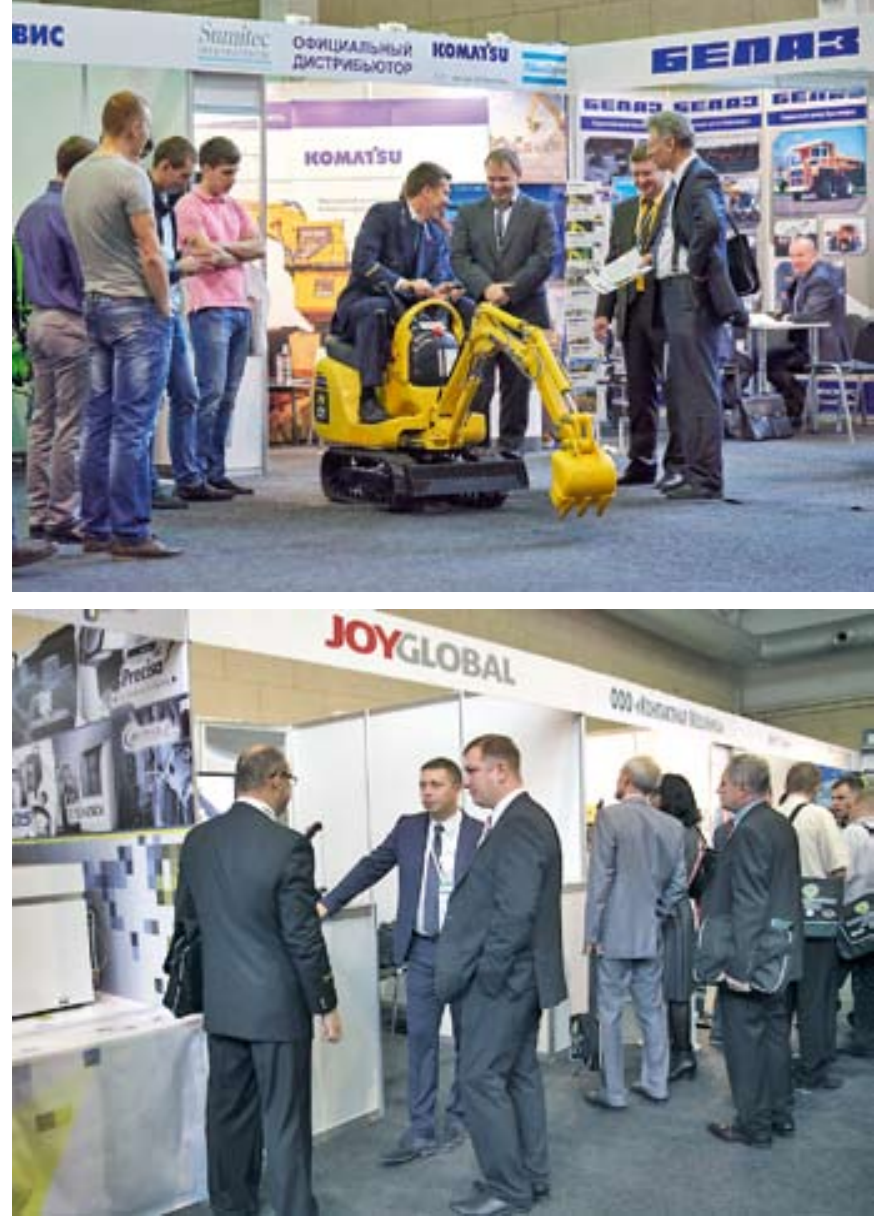

Кроме того, в рамках конференции проходила специализированная выставка, на которой были представлены продукция, техника и технологии для горнодобывающей промышленности таких крупнейших российских и зарубежных компаний, как Sumitec international, Mining Solutions, Joy Global, Альсбах-Центр, БелАЗ и других.

Один из участников выставки - Бородинский ремонтно-механический завод - БРМЗ (входит в состав СУЭК) представил уникальное оборудование для обогатительных фабрик - насос для перекачки шлама. Он разработан конструкторами завода в рамках программы импортозамещения. Еще одно предприятие СУЭК в Красноярском крае - Назаровское горно-монтажное наладочное управление (НГМНУ) представило спектр своих услуг: сегодня предприятие выполняет все виды ремонтов горнотранспортного оборудования и электрооборудования.

\section{ВНЕДРЕНИЕ ЛУЧШИХ РЕШЕНИЙ, ПРОВЕРЕННЫХ РЕКОРДАМИ}

Во время пленарного заседания и работы секций участники заслушали и обсудили 10 докладов самой различной тематики — от развития функционала отдельных служб до внедрения робототехники и инноваций, таких как «Интеллектуальный карьер».

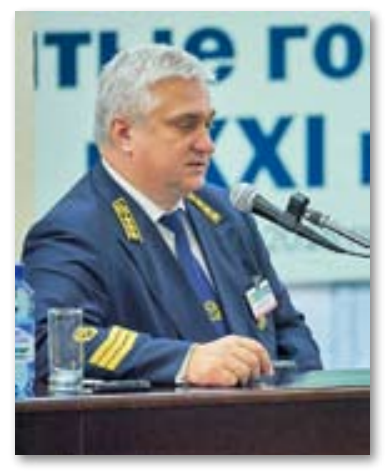

Заместитель генерально20 директора - директор по производственным операциям $A O$ «СУЭК» Владимир Борисович Артемьев в своем докладе отметил, что одно из слагаемых успешной работы угледобывающих предприятий компании - это прочность проектных решений, которые использовались при их создании. «Мощь, не подверженная изменениям, - так Артемьев охарактеризовал производственный потенциал СУЭК. - Именно она, а также внедрение новой техники, новых подходов, постоянная работа над повышением эффективности позволили нам за последние 10 лет в 3 раза увеличить производительность труда. С 2012 года мы стабильно достигаем высоких показателей производительности на различных видах техники, более того - устанавливаем рекорды мирового уровня, подтвержденные производителями горных машин».

В. Б. Артемьев подчеркнул, что ближайшими конкурентами твердого топлива являются нефть и газ, но, тем не менее, у угля есть ряд преимуществ, позволяющих ему выигрывать в этой конкурентной борьбе.

На большинстве предприятий открытой угледобычи постепенная выемка запасов приводит к увеличению глубины отработки и росту текущего коэффициента вскрыши. Этот показатель в целом по компании АО «СУЭК» за период с 2005 г. увеличился в 1,8 раза (табл. 1).

С целью минимизации негативного влияния отрицательных факторов на работу предприятий открытой угледобычи начиная с 2005 г. был принят ряд принципиальных операционных улучшений, которые отразились на положительной динамике всех показателей.

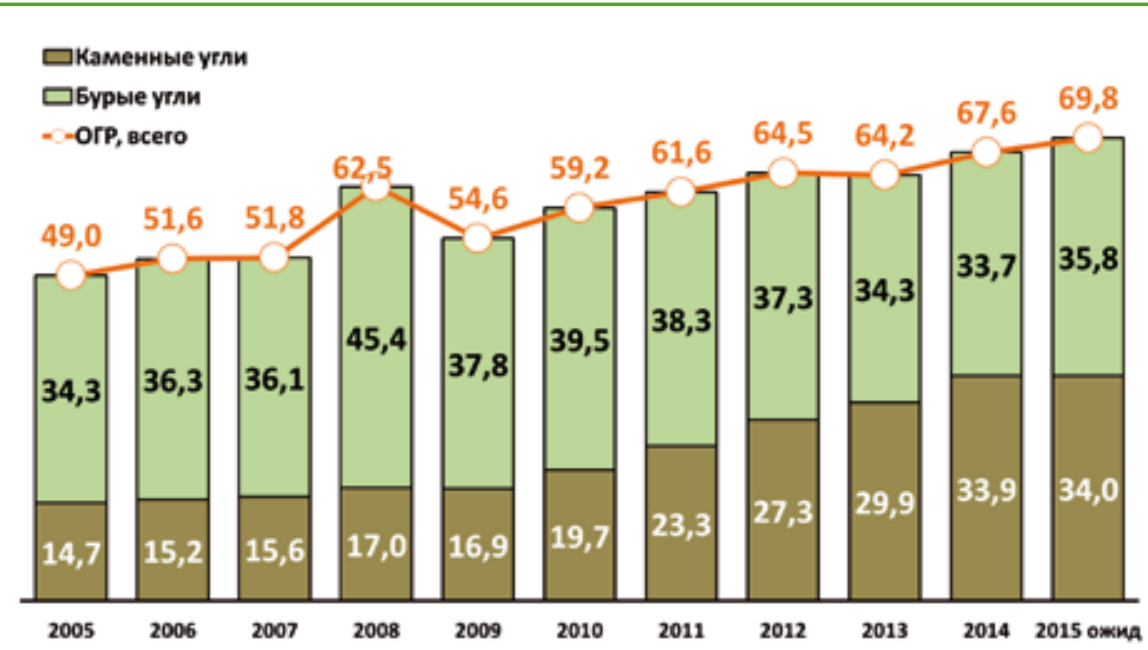

Рис. 1. Открытые горные работы, добыча, млн m
Комплекс организационно-технических мероприятий, осуществленных на разрезах компании, позволил на $42 \%$ поднять общие объемы добычи угля открытым способом. При этом добыча каменных углей выросла в 2,3 раза (рuс. 1).

Весь прирост добычи каменных углей на разрезах компании был реализован на экспорт, который вырос в 3,6 раза, объемы поставок на внутренний рынок практически не изменились. Экспортная составляющая поставок каменных углей с разрезов выросла с 42 \% в 2005 г. до 71 \% в 2014 г. (рис. 2)

Рост объемов производства при одновременной оптимизации численности позволил поднять произ- 
Таблича 1

АО «СУЭК» сегодня. Открытые горные работы

\begin{tabular}{|c|c|c|c|c|c|}
\hline Филиалы & Разрезы & $\begin{array}{c}\text { Добыча } \\
\text { угля, млн т }\end{array}$ & $\begin{array}{l}\text { Вскрыша, } \\
\text { млн т }\end{array}$ & $\begin{array}{c}\text { Производительность } \\
\text { труда по добыче угля, } \\
\text { т/чел. /мес. }\end{array}$ & $\begin{array}{c}\text { Производительность } \\
\text { труда по горной массе, } \\
\text { м³/чел. /мес }^{3}\end{array}$ \\
\hline $\begin{array}{l}\text { ОАО «СУЭК-Кузбасс», } \\
\text { Кемеровская область }\end{array}$ & $\begin{array}{c}\text { Разрезоуправление } \\
\text { «Заречное» } \\
\text { (два разреза) }\end{array}$ & 6236 & 43356 & 569 & 4539 \\
\hline АЩ «СУЭК-Красноярск» & $\begin{array}{l}\text { «Бородинский» } \\
\text { «Березовский» } \\
\text { «Назаровский» }\end{array}$ & $\begin{array}{l}18086 \\
6212 \\
3788\end{array}$ & $\begin{array}{c}17602 \\
5787 \\
15194\end{array}$ & $\begin{array}{l}778 \\
649 \\
364\end{array}$ & $\begin{array}{l}1366 \\
1136 \\
3061\end{array}$ \\
\hline Красноярский край, всего & & 28087 & 38583 & 650 & 0 \\
\hline Республика Бурятия & $\begin{array}{l}\text { «Тугнуйский» } \\
\text { «Никольский» }\end{array}$ & 13847 & 66202 & 937 & 5712 \\
\hline Забайкалье & $\begin{array}{l}\text { «Харанорский» } \\
\text { «Восточный» } \\
\text { «Апсатский» }\end{array}$ & $\begin{array}{c}2804 \\
991 \\
389\end{array}$ & $\begin{array}{l}11614 \\
4575 \\
4717\end{array}$ & $\begin{array}{c}407 \\
316 \\
99\end{array}$ & $\begin{array}{l}2025 \\
1720 \\
1269\end{array}$ \\
\hline Забайкалье, всего & & 4184 & 20906 & 300 & 1744 \\
\hline ООО «СУЭК-Хакасия» & «Черногорский» & 7112 & 39110 & 674 & 5276 \\
\hline Республика Хакасия & $\begin{array}{c}\text { «Восточно-Бейский» } \\
\text { «Изыхский» }\end{array}$ & $\begin{array}{c}3022 \\
849\end{array}$ & $\begin{array}{c}14684 \\
3647\end{array}$ & $\begin{array}{l}574 \\
513\end{array}$ & $\begin{array}{l}3830 \\
4516\end{array}$ \\
\hline Республика Хакасия, всего & & 10983 & 57441 & 629 & 4768 \\
\hline $\begin{array}{l}\text { ОАО «Приморскуголь», } \\
\text { Приморский край }\end{array}$ & $\begin{array}{c}\text { Разрезоуправление } \\
\text { «Новошахтинское» } \\
\text { (два разреза) }\end{array}$ & 3915 & 17334 & 463 & 2588 \\
\hline $\begin{array}{l}\text { ОАО «Ургалуголь», } \\
\text { Хабаровский край }\end{array}$ & «Буреинский» & 2520 & 13189 & 387 & 2282 \\
\hline АО «СУЭК», всего & 16 разрезов & 69772 & 257010 & 605 & 2414 \\
\hline
\end{tabular}
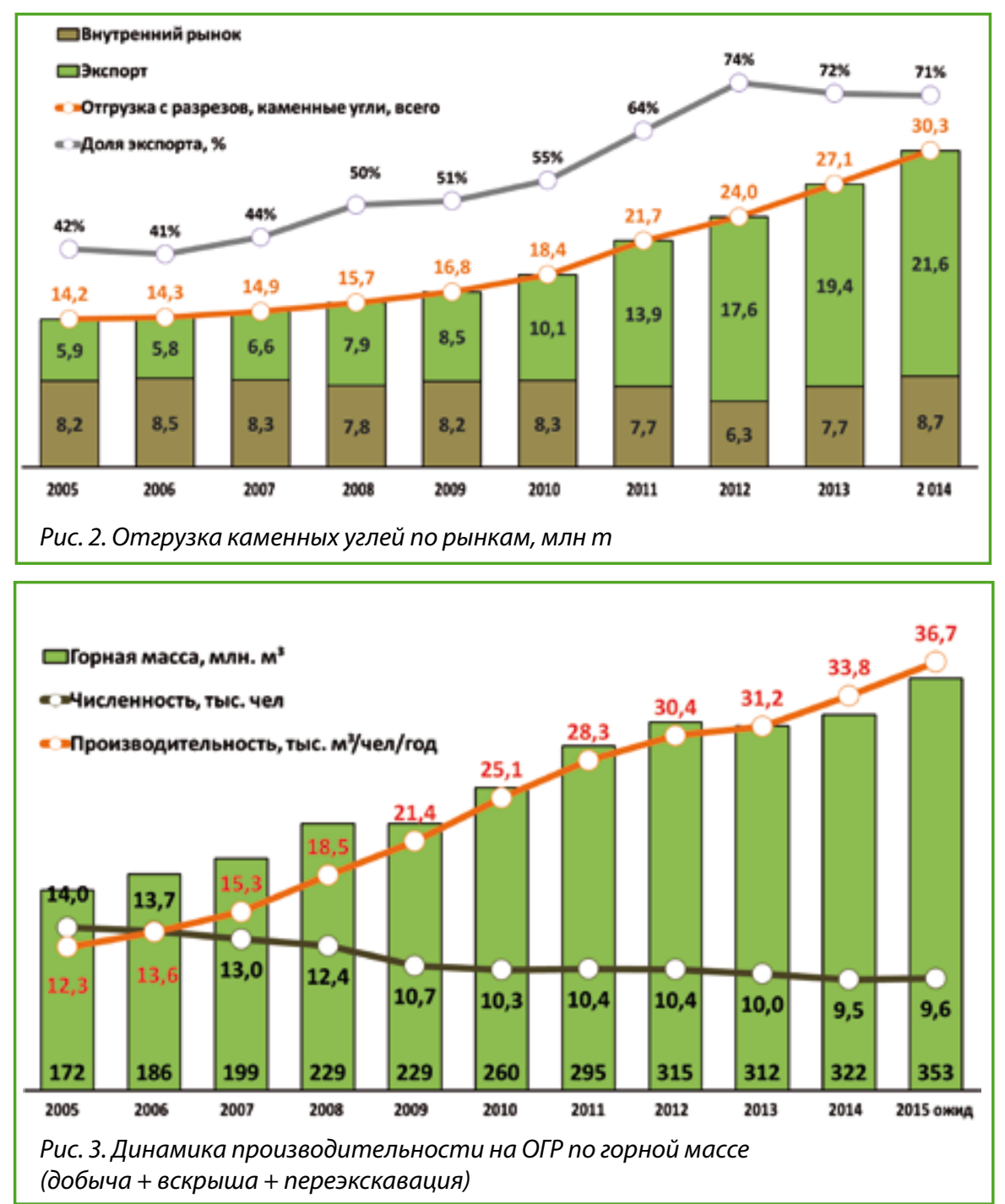

водительность труда на предприятиях открытой угледобычи в 2 раза, а в расчете на горную массу она возросла почти в 3 раза (рuс. 3).

Растущие экспортные рынки и связанные с этим приоритеты, отдаваемые развитию каменноугольных разрезов позволили увеличить добычу угля на этих предприятиях в 2,3 раза, на буроугольных разрезах, из-за ограниченности внутреннего рынка сбыта, она осталась практически неизменной. Производительность труда по добыче каменных углей в расчете на горную массу выросла в 3,4 раза, а бурых в 2,2 раза, в основном за счет оптимизации процессов.

Начиная с 2005 г. в разрезы инвестировано около 39,7 млрд руб., при этом приоритет отдается предприятиям, добывающим каменные угли, на долю которых пришлось $84 \%$ всех инвестиций в ОГР (33,4 млрд руб.). За период 2006-2014 гг. общее количество экскаваторов-драглайнов и мехлопат увеличилось на 7 единиц, при этом производительность их выросла 2 раза. Повышение показателя производительности произошло как за счет увеличения единичной мощности машин, так и за счет улучшения их работы - при увеличении среднего объема ковша в 1,13 раза, удельная производительность на кубоковш выросла в 
1,66 раза (в расчете участвуют экскаваторы с емкостью ковша $7 \mathrm{~m}^{3}$ и более).

С октября 2013 г. в компании $\mathrm{AO}$ «СУЭК» принята стратегическая программа повышения эффективности работы парка оборудования на открытых горных работах, которая предусматривает дальнейшее улучшение использования основного горно-транспортного оборудования. Результаты работы в этом направлении за истекший период позволяют надеяться, что целевые показатели коэффициентов использования базовых экскаваторов и автосамосвалов будут достигнуты.

Начиная с 2012 г. установлено 16 мировых рекордов производительности оборудования. Все рекорды подтверждены предприятиями - производителями оборудования. Рекордные нагрузки достигались после тщательного анализа, выявления узких мест и оптимизации технологии работы всего автовскрышного комплекса. В процессе достижения рекордных нагрузок на практике апробируются передовые технологические решения. Внедрение лучших решений позволяет увеличить средние нагрузки на экскаваторы в последующие периоды.

В период с 2005 по 2014 г. осуществлялась оптимизация способов транспортирования горной массы с целью удешевления этого процесса. Поскольку применение бестранспортного и транспортно-отвального способов вскрыши ограничено горно-геологическими условиями отработки запасов, основной упор был сделан на максимальное сокращение объемов дорогойжелезнодорожной вскрыши и повышение доли автотранспортной.

К началу 2015 г. железнодорожная вскрыша была полностью ликвидирована на «Тугнуйском», «Черногорском», «Харанорском» и «Павловском» разрезах, и основным видом транспорта стал автомобильный, на долю которого приходится 72 \% объемов транспортировки горной массы. В настоящее время железнодорожная вскрыша применяется только на двух разрезах компании: «Бородинском» и «Назаровском», что обусловлено одинаковым способом транспортировки на них угля и вскрыши.

Основные объемы грузоперевозок осуществляются с помощью автосамосвалов. Основное направление технической политики АО СУЭК - увеличение единичной мощности. За период с 2006 г. средняя грузоподъемность автомобиля увеличилась в 2,4 раза, а производительность одной автотонны возросла в 2 раза.

В качестве примера комплексного решения на открытых горных работах В.Б. Артемьев рассказал о внедрении единой системы диспетчеризации и перспективах развития АСУ горно-транспортного комплекса «Карьер». Достигаемые эффекты: экономия дизельного топлива до $10 \%$; увеличение коэффициента использования пробега на 7,6\% за счет сокращения холостых пробегов; увеличение производительности на $12,7 \%$ по объемам перевозок и на 19,2\% по грузообороту; снижение удельного энергопотребления экскаваторов на куб горной массы на $\approx 30 \%$; оптимизация грузопотоков, увеличение времени производительной работы оборудования; планомерный ремонт и обслуживание парка машин, увеличение сроков службы узлов и агрегатов.

В перспективе - оснащение всего парка транспортных средств предприятий, входящих в структуру холдинга оборудованием ГЛОНАСС; мониторинг и оптимизация транс- портных перевозок компании; проведение НИОКР по созданию системы дистанционного безоператорного управления технологическим транспортом предприятий.

При этом компанией привлекаются научный потенциал и современные информационные технологии. Имеется собственный институт СибНИИ углеобогащения (5 филиалов), где осуществляются проектирование угледобывающих и перерабатывающих предприятий, внедрение современных технологий.

На базе НТЦ НИИОГР (г. Челябинск) специалисты компании занимаются планированием ОГР, научной организацией труда, планированием уровня безопасности. А применяемые информационные технологии говорят сами за себя: системы диспетчеризации АСД «Карьер»; система планирования и проектирования БВР Blast Maker; комплекс моделирования и планирования ОГР XPACK/XERAS; MES системы; системы проектирования Vulcan, BIM-моделирование, LIMN-проектирование переработки; беспилотные летательные аппараты для маркшейдерских работ; единая книга предписаний.

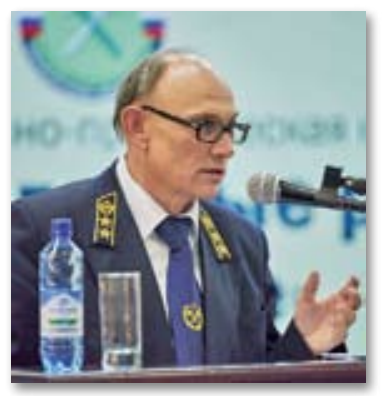

Исполнительный директор АО «СУЭК-Красноярск»Андрей Витальевич Федоров дселал доклад на тему «Обоснование условий обеспечения конкурентоспособности угледобывающих предприятий в среде высокой изменчивости потребления рынка». Он отметил, что рынок и производство бурых углей на сегодня являются очень конкурентной средой. Это обусловлено уникальными месторождениями и их горно-геологическими условиями. Очень быстро можно построить разрез, где коэффициент вскрыши будет равен 1, начать добывать достаточно дешевый уголь, и поэтому на очень многих предприятиях производственные мощности значительно превышают потребление.

«Вэтихусловиях компания «СУЭК-Красноярск» занимает лидирующее положение, так как исторически сложилось, что все ТЭЦ и ГРЭС (угольная генерачия) спроектированы под наши угли» - заметил А. В. Федоров.

Но сложившийся рынок бурых энергетических углей конкурентный и изменчивый, при этом заявки потребителей значительно превышают фактическое потребление. Для сохранения конкурентоспособности в условияхтакого рынка угледобывающие предприятия должны быть максимально адаптивны и гибки. У них должна быть возможность регулировать операционные затраты в соответствии с годовым и сезонным фактически сложившимся потреблением угля (рис. 4).

Критериями оценки гибкости и адаптивности предприятий могут служить: доля условно-постоянных расходов (УПР) в себестоимости, величина норматива подготовленных и готовых к выемке запасов, общая балансовая стоимость основных фондов и инфраструктуры, численность управленческого и административного аппарата. Сегодня УПР в компании «СУЭК-Красноярск» составляют от 65 до75\%. Объемы добычи ведут себя нестабильно из-за изменения конъюнктуры рынка. Колебания за период с 2008 по 2014 г. достигают 29\%. Управление затратами затрудняется боль- 


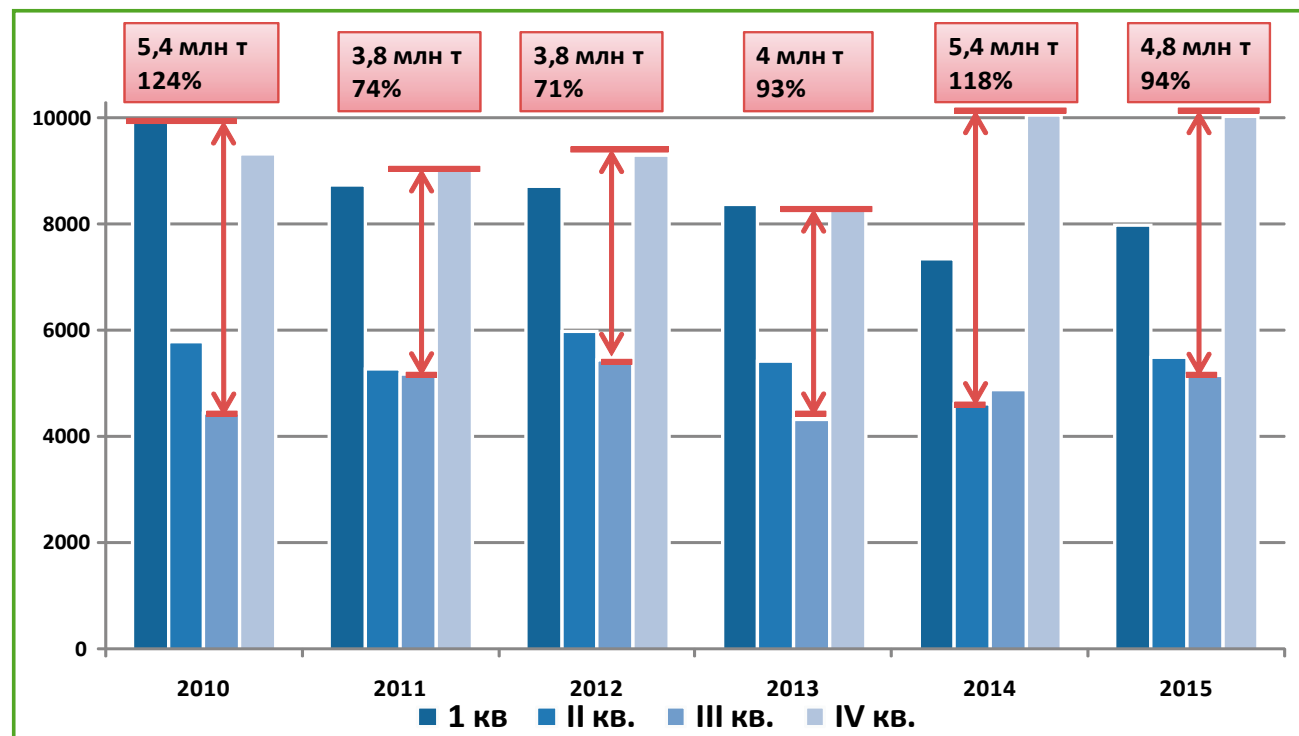

Pис. 4. Сезонные отклонения по добыче угля

шим удельным весом условно-постоянных расходов, что обусловлено действующими технологиями в процессе добычи и вскрыши угля и сезонными колебаниями (рuс. 5).

В связи с тем, что постоянные затраты почти всегда превышают переменные, предприятие плохо реагирует на изменения и, таким образом, можно посчитать лишние затраты - это примерно 1 млрд руб. в год.

Максимально соответствуют вышеприведенным критериям автотранспортные и циклично-поточные техно-

Таблича 2

\section{Существующая технология}

\begin{tabular}{|l|c|c|}
\hline \multicolumn{1}{|c|}{ Показатели } & Постоянные & Переменные \\
\hline МТР & $26 \%$ & $74 \%$ \\
\hline Энергообеспечение & $39 \%$ & $61 \%$ \\
\hline УПХ & $75 \%$ & $25 \%$ \\
\hline ФОТ с ЕСН & $94 \%$ & $6 \%$ \\
\hline Амортизация & $100 \%$ & $0 \%$ \\
\hline Налоги & $16 \%$ & $84 \%$ \\
\hline Прочие & $100 \%$ & $0 \%$ \\
\hline Себестоимость & $69 \%$ & $31 \%$
\end{tabular}

угля ина изменчивом рынке. Кприм угля ина изменчивомрынке. К примеру, бьла приведена современная технология разработки разреза «Бородинский» с грузопотоками. Эта технология была просчитана в кандидатской работе А.В. Федорова «Блочная отработка Бородинского месторождения с использованием экскаваторно-автомобильного комплекса». Такая перестройка стоит примерно 6 млрд руб. Она будет окупаться за счет двух факторов - снижения себестоимости и получения более гибкой технологии - примерно за три года.

Таблица 3

\section{При изменении технологии}

\begin{tabular}{|l|c|c|}
\hline \multicolumn{1}{|c|}{ Показатели } & Постоянные & Переменные \\
\hline МТР & $26 \%$ & $74 \%$ \\
\hline Энергообеспечение & $31 \%$ & $69 \%$ \\
\hline УПХ & $51 \%$ & $49 \%$ \\
\hline ФОТ с ЕСН & $61 \%$ & $39 \%$ \\
\hline Амортизация & $100 \%$ & $0 \%$ \\
\hline Налоги & $16 \%$ & $84 \%$ \\
\hline Прочие & $100 \%$ & $0 \%$ \\
\hline Себестоимость & $54 \%$ & $46 \%$ \\
\hline
\end{tabular}

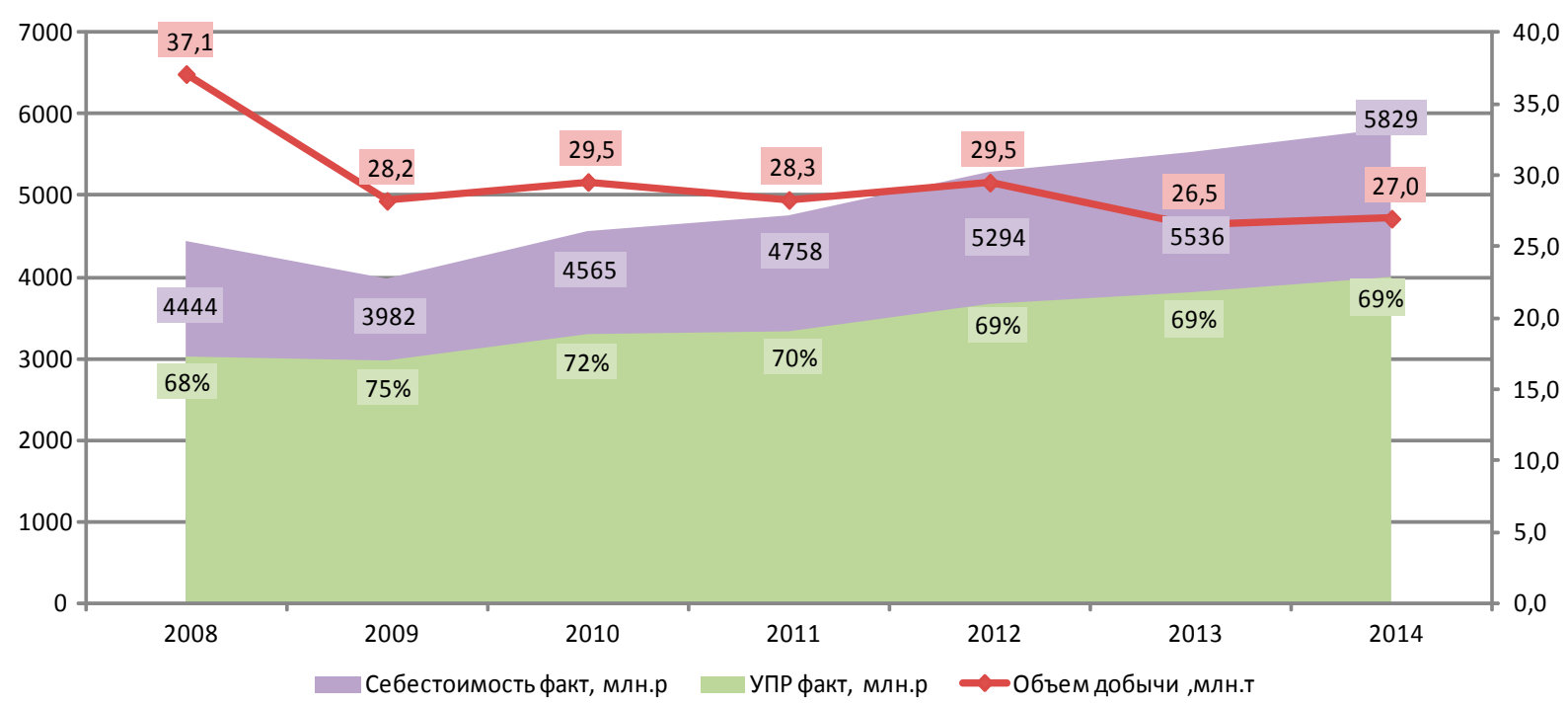

Рис. 5. Показатели деятельности добычных предприятий Красноярского региона АО «СУЭК» за 2008-2014 г2. 


\section{Доклад управляющего фи- лиалом ООО «СибНИИугле-} обогащение» Сергея Романовича Исламова был посвящен перспективам термического обогащения бурых углей методом частичной газификации и вызвал большой интерес уучастников конференции.

Мировая экономика вступила в длительную фазу неустойчивого функционирования, и для

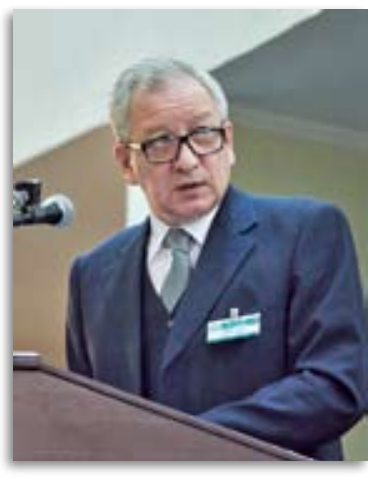
успешной адаптации компаний к новым экономическим условиям необходима новая технологическая политика, которая в том числе включает в себя термическую переработку углей с высоким содержанием летучих веществ.

«В первую очередь, это относится к бурым углям Канско-Ачинского бассейна, которые до настоящего времени считаются низкосортным топливом, хотя лично я называю его топливом XXI века» - подчеркнул докладчик. Парадокс заключается в том, что до настоящего времени не разработана адекватная технология использования бурого угля, которая смогла бы в полной мере раскрыть уникальные свойства этого топлива. А уникальность за-

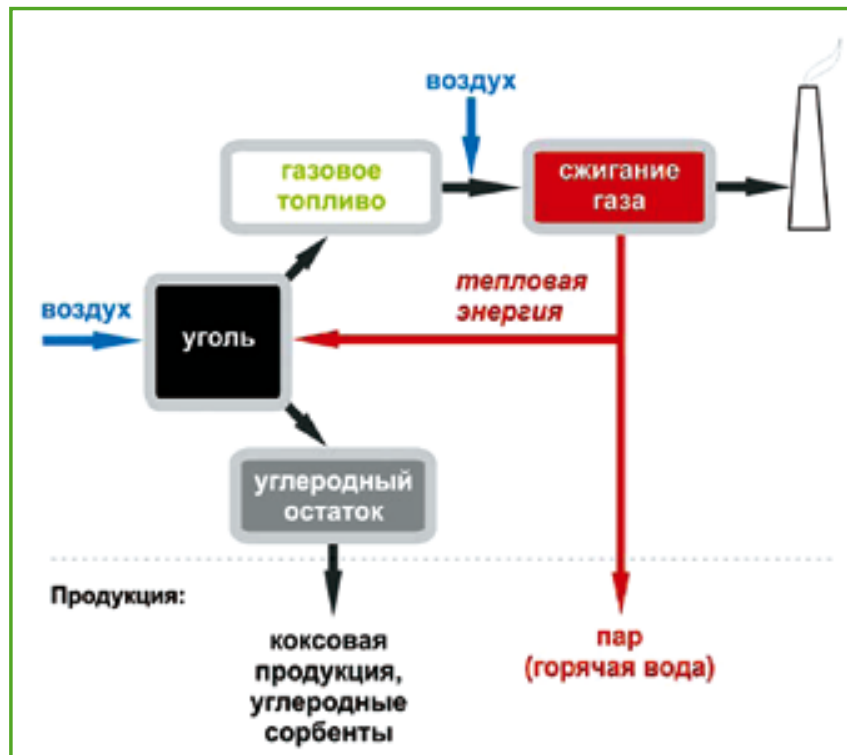

Рис. 6. Технология ТЕРМОКОКС

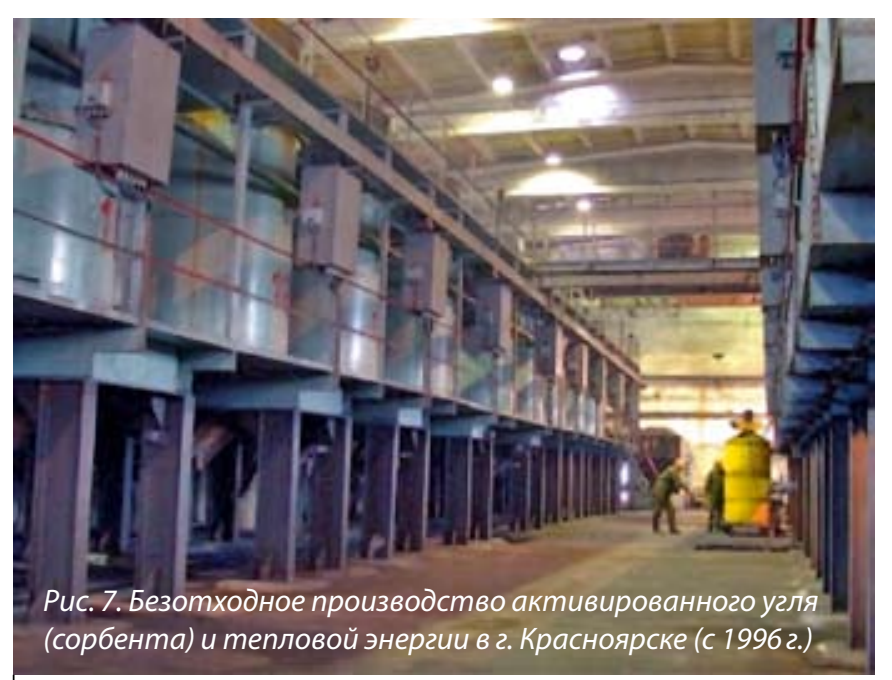

ключается в том, что до $40 \%$ органической массы бурого угля - это летучие вещества, очень низкая зольность, зола содержит очень мало таких компонентов, как сера, фосфор и др. И, наконец, он очень дешевый.

Потенциал классической угольной теплоэнергетики в настоящее время полностью исчерпан. Технологический принцип индустриального сжигания угля без изменения используется со времен промышленной революции в Европе (с начала XVIII века). КПД увеличить практически невозможно, а повышение экологической безопасности достигается путем увеличения затрат на очистные сооружения. Не решена проблема и золошлаковых отвалов. Существует необратимость тенденции роста себестоимости энергетической продукции.

Для решения проблемы необходимо заменить технологический принцип использования угля - новая технология должна обеспечить радикальное снижение себестоимости продукции и обеспечить высокий уровень экологической безопасности, не за счет увеличения инвестиций в стадию очистки выбросов и утилизацию золошлаков, а за счет радикального снижения объемов вредных отходов (рис. 6).

С точки зрения как экономической, так и экологической эффективности использования углей с высоким содержанием летучих веществ, для производства тепловой энергии целесообразно сжигать только газовую компоненту угля, а коксовый остаток необходимо использовать как второй ценный продукт: активированный уголь (сорбент); специальное технологическое топливо; бездымное бытовое топливо; углеродный восстановитель для электрометаллургии и металлургии нового поколения, то есть как заменитель классического кокса, производимого из коксующихся углей.

Суть новой технологии частичной газификации угля заключается в частичной газификации угля с параллельным производством двух продуктов - газового топлива (тепловой энергии) и углеродного материала с теплотой сгорания около 7000 ккал/кг. Эта технология запатентована под наименованием «Термококс».

Направления использования буроугольного кокса:

- углеродный сорбент МК-А (аналог немецкого продукта фирмы RWE, но с повышенными на $40 \%$ сорбционными показателями);

- технологическое топливо для цементных (глиноземных) заводов - заменитель углей марок Т и СС, низшая теплота сгорания - $6200-7000$ ккал/кг;

- исходное сырье для бездымных брикетов (бытовое топливо) - экспортная продукция в Европу и Китай.

Но самое главное стратегическое направление - металлургия:

- базовый компонент пылеугольного топлива для вдувания в домны (технология $\mathrm{PCl}$ ) агломерационное топливо;

- брикетированное металлургическое топливо - заменитель классического кокса в электрометаллургии (заводы по производству ферросплавов, кремния и т.п.);

- высокореакционный углеродный восстановитель для металлургии нового поколения - недоменное производство чугуна.

Первая котельная с частичной газификацией угля действует г. Красноярске с 1996 г. (рис. 7). Производятся 
активированный уголь (сорбент) и тепловая энергия. Генераторный газ без предварительной очистки бездымно сжигается в котельной мощностью 10 МВт. Активированный уголь поставляется в ОАО «Норильский никель» и мусоросжигающие заводы Подмосковья по цене более 40 тыс. руб. /т.

Единственный отход производства - продукты сгорания газового топлива. Энергетический котел имеет экологические показатели, близкие к котлу на газовом топливе и не имеет золошлаковых отходов. Кокс производится с нулевыми выбросами (zero emission). Продажа термококса, как минимум, полностью компенсирует затраты котельной (ТЭЦ) на приобретение топлива, так что газовое топливо имеет условно нулевую стоимость!

Генеральный директор ООО «РУСАЛ ИТЦ» Дмитрий Николаевич Макаров в своем выступлении рассказал о технологических инновациях компании, которые связаны с перспективами замещения традиционных углеводородов углями Канско-Ачинского бассейна (КАБ).

В ООО «РУСАЛ ИТЦ» одним из основных преимуществ твердого топлива называют его ценовую доступность, что особенно важно в условиях энергоемких производств. «Уголь - это наиболее дешевое из всех видов топлива, - подчеркнул Д. Н. Макаров, - и сегодня мы на предприятиях системы РУСАЛ активнозанимаемся вопросами вовлечения бурого угля в производственные процессы».

Удельная приведенная стоимость неэкспортируемого топлива будет снижаться относительно газа, мазута и экспортных марок углей, так как в конъюнктуре рынка бурых углей предложение значительно превышает спрос, а использование мазута в качестве топлива чем дальше, тем больше влечет растущие выбросы оксидов серы (табл. 4).

В России бурые угли применяются только в качестве энергетического топлива, в мире наиболее близкие по качеству к углям КАБ добываются в Таиланде и Индонезии. Например, в Таиланде огромный цементный завод использует в качестве технологического топлива бурые угли. Основываясь на этом опыте компания «РуСАЛ ИТЦ» открыла проект «Перевод передела спекания АГК на бурые угли Канско-Ачинского бассейна». Модернизация угольного передела связана со строительством трех новых вертикальных мельниц LOESCHE (рuс. 8).

Как рассказал Д.Н. Макаров, еще один фактор в пользу модер- низации котлоагрегатов предприятий под использование бурого угля - это стабильный химический состав твердого топлива. «Стабильное содержание золы, при этом достаточно низкое, позволяет снизить образование сажи, а значит, сократить количество остановокоборудования для ремонтных работ».

Технологии газификации углей активно развивались в России до 1950-х годов. В настоящее время наиболее широко газификация представлена в Китае - к 2017 г. планируется ввести в эксплуатацию производство 32 млрд м ${ }^{3}$ синтетического газа, а к 2020 г. - 50 млрд м³. Газификация углей используется как в технологических, так и в энергетических целях (для улучшения экологических показателей). Ограничениями для применения подобных технологий в России являются: высокая стоимость оборудования, отсутствие опыта получения разрешительной документации на применение оборудования такого назначения. Для негазифицированных районов технология газификации углей является единственной альтернативой мазуту в классе беззольных видов топлива.

Еще один продукт, который вызывает интерес у металлургов - это полукокс, производство которого освоили на разрезе «Березовский» (СУЭК). Использование полукокса бурого угля (ПБУ), помимо его горючих свойств, в качестве теплоизоляционного материала в подине электролизера дает большие преимущества в сравнении с традиционными огнеупорами: достаточно низкий коэффициент теплопроводности; возможность кладки бесшовного теплоизоляционного слоя (химическая устойчивость всей футеровки); высокая криолитоустойчивость; стабильный химический состав; высокая скорость монтажа и снижение трудоемкости операций; возможность рециклинга (до $80 \%)$. Максимальный объем потребления ПБУ в футеровке

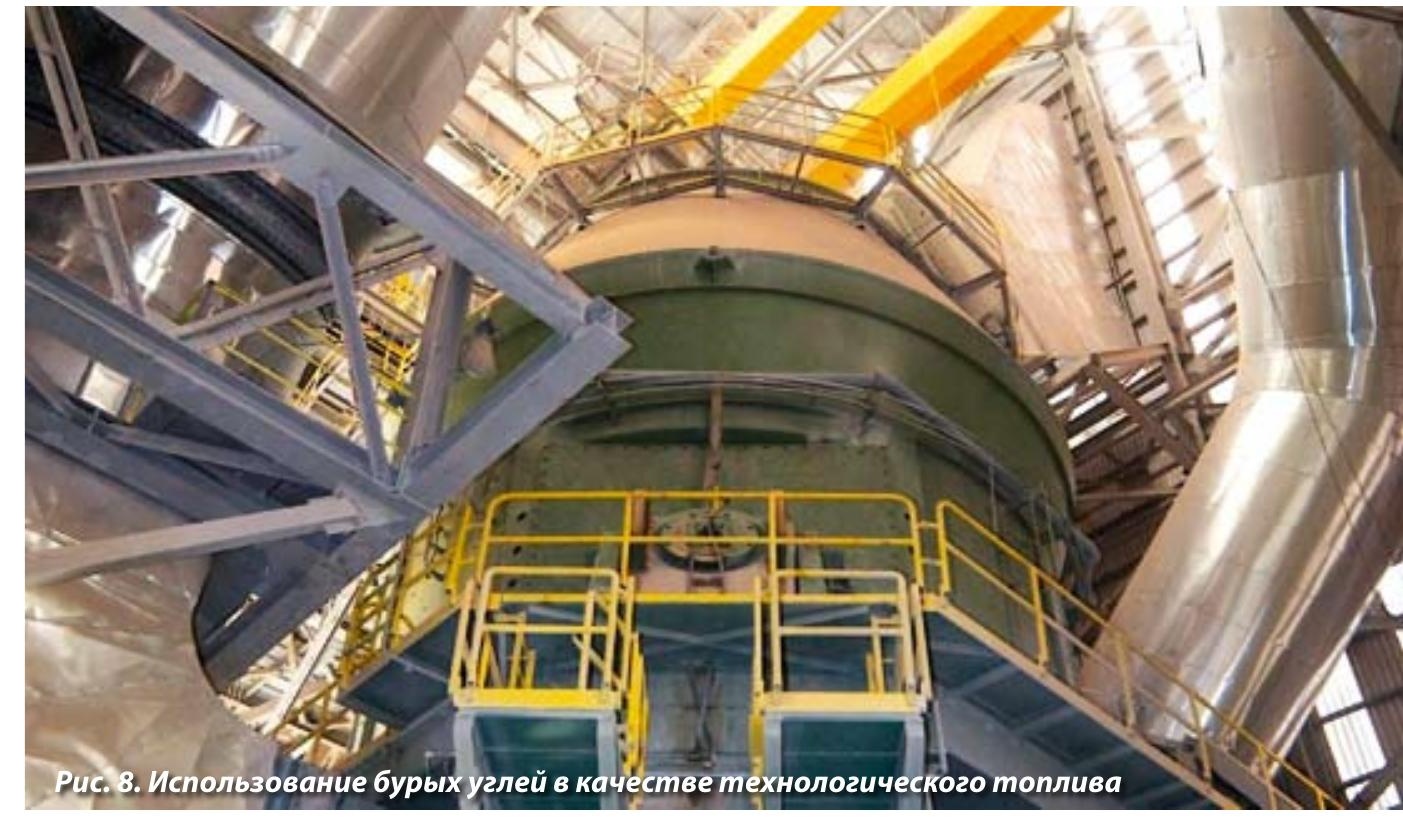

Приведенная стоимость условного топлива для различных видов энергоносителей

\begin{tabular}{|c|c|c|c|c|c|c|c|c|c|}
\hline Вид топлива & Мазут & $\begin{array}{c}\text { Уголь } \\
\text { марки Т }\end{array}$ & $\begin{array}{c}\text { Уголь } \\
\text { марки Д }\end{array}$ & $\begin{array}{c}\text { Уголь } \\
\text { марки Г }\end{array}$ & $\begin{array}{c}\text { Уголь } \\
\text { марки Дг }\end{array}$ & $\begin{array}{c}\text { Уголь мар- } \\
\text { ки 2БР }\end{array}$ & $\begin{array}{c}\text { Уголь мар- } \\
\text { ки ЗБР }\end{array}$ & $\begin{array}{l}\text { Газ природ- } \\
\text { ный, тыс. м }\end{array}$ & Спг \\
\hline Цена, руб. /т & 12000 & 2050 & 1550 & 1150 & 1725 & 627 & 812 & 3646 & 11266 \\
\hline Цена, дол. США/т & 184,62 & 31,54 & 23,85 & 17,69 & 26,54 & 9,65 & 12,49 & 56,09 & 173,32 \\
\hline Цена, дол. США/т у. т. & 131,88 & 32,39 & 31,63 & 19,92 & 35,20 & 18,69 & 24,21 & 48,77 & 110,39 \\
\hline
\end{tabular}




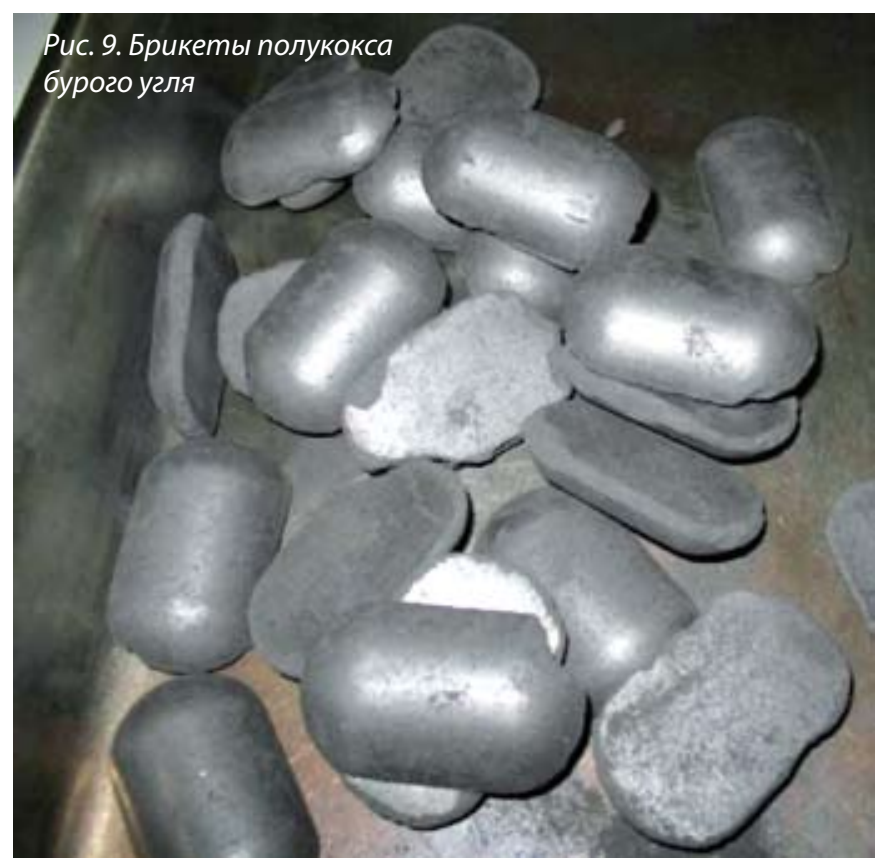

электролизеров «РУСАЛ» около13 тыс. т в год. Технологии и материалы являются экспортируемыми (рис. 9).

Также компания «РУСАЛ ИТЦ» планирует использовать полукокс бурых углей в шихте при производстве кремния, то есть введение брикетов полукокса бурого угля в состав шихты взамен каменных и древесных углей при плавке кремния в руднотермических печах.

\section{Генеральный директор} ОАО «ВИСТ Групп» Дмитрий Ярославович Владимиров в своем выступлении говорил о проблематике и актуальности внедрения таких систем, как «Интеллектуальный карьер». Месторождения полезных ископаемых истощаются, добыча ведется в труднодоступных и тяжелых климатических, сложных горно-геологических условиях, не хватает квалифицированного персонала практически во всех регионах, высокие капитальные и операционные затраты, связанные с созданием инфраструктуры, обеспечивающей проживание персонала (рис. 10).

Д.Я. Владимиров подчеркнул, что в настоящее время есть все предпосылки для внедрения безлюдных технологий добычи. В первую очередь это современное развитие технологий:высокоточная навигация и широкополосная связь; робототехника и дистанционное управление; искусственный интеллект (алгоритмы управления и оптимизация); технологии «big data и predictive analytics», которые позволяют одновременно обрабатывать огромные массивы данных, предсказывать и анализировать различные взаимосвязи; интернет вещей (iot), который позволяет организовывать эффективное взаимодействие между машинами и механизмами в различных технологических процессах.

Докладчик отметил, что развитие только технологий не позволит внедрить безлюдные технологии - важно развитие нормативной базы. В настоящее время сделан первый шаг, и в новых Федеральных нормах и правилах в области промышленной безопасности есть пункт 22, в котором говорится о том, что уже можно применять безлюдные технологии по отдельным проектам.

Конечно, развитие нормативной базы должно идти вперед, должны создаваться стандарты проектирования новых технологий. И если говорить о существующих предприятиях, то здесь возможны: постепенная замена горной техники на автономную; использование дистанционного управления; электронная выдача нарядов; оптимизация работы транспорта и персонала; тотальный контроль за техникой и персоналом.

А если говорить о новом предприятии, то можно осуществить: единовременный переход к роботизированному горно-транспортному комплексу; изменение параметров открытой геотехнологии; кардинальное изменение в организации производства и планировании горных работ; новые подходы к управлению промышленной безопасностью и рисками; массовое применение современных АСУ горно-транспортного комплекса и АСД на открытых горных работах.

«Недалеко то время, когда автосамосвалы и экскаваторы будут производиться без кабины шофера и машиниста. И если в настоящее время мы говорим, что система «Интеллектуальный карьер» более гибкая, чем традиционная система, то автотранспортный комплекс, на котором нет водителей, будет еще более гибким», сказал в заключение Д.Я. Владимиров.

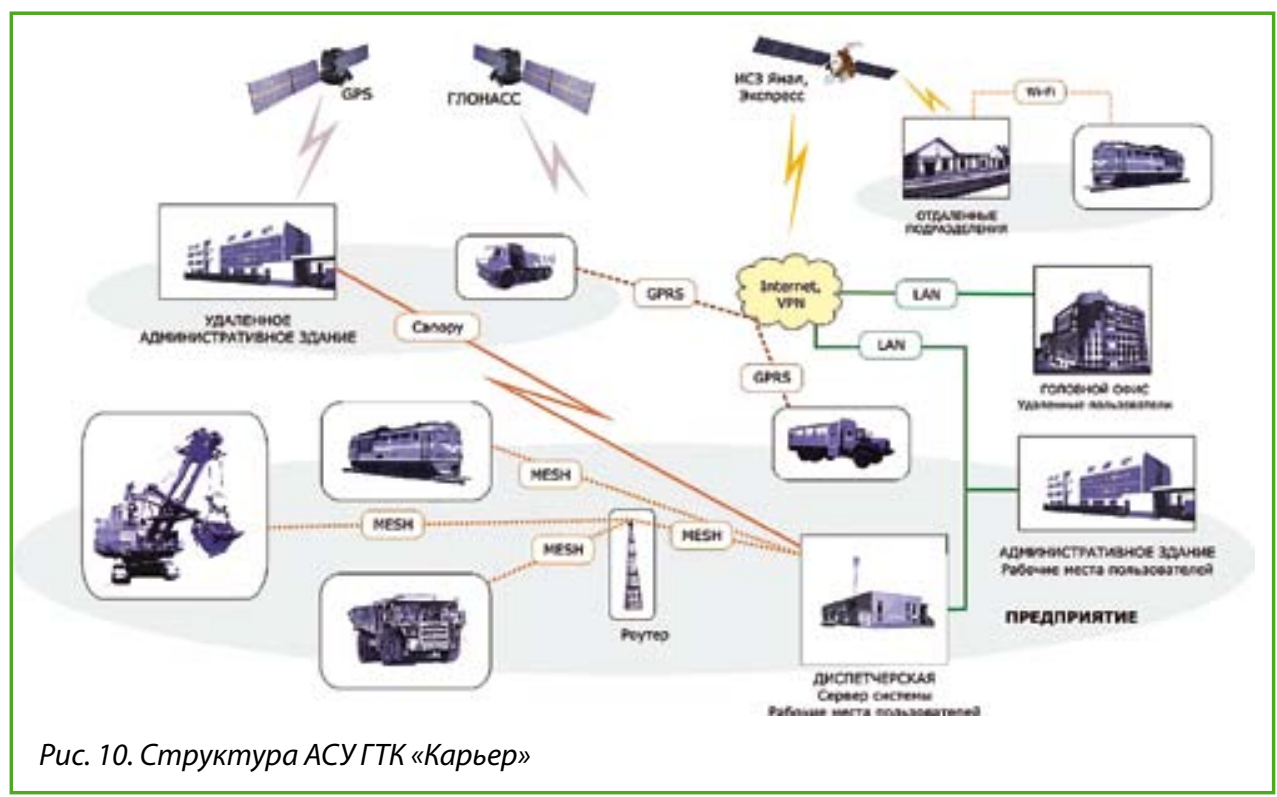




\section{«ДЕНЬ КОМПАНИИ СУЭК»}

В рамках работы конференции «Открытые горные работы в XXI веке» состоялся День компании СУЭК. Мероприятие было организовано Министерством промышленности, энергетики и торговли Красноярского края и АО «СУЭК-Красноярск» с целью расширения кооперационных связей между крупнейшей угледобывающей компанией и компаниями-поставщиками товаров и услуг, работающих в красноярском регионе. Узнать особенности организации закупочной деятельности $\mathrm{AO}$ «СУЭК-Красноярск» пришли представители около тридцати предприятий и организаций.

Присутствующих приветствовал заместительминистрапромышленности, энергетики и торговли Красноярского края Василий Викторович Чернов: «День компании - это важное событие для внутрикраевой кооперации. Оборудование, производимое в Красноярском крае, должно работать и поставляться на предприятия Красноярского края. АО «СУЭК-Крас-

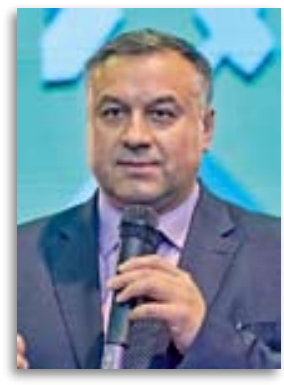
ноярск» - это крупнейшая компания региона, флагман в производственных мощностях, по новейшим технологиям. И такие Дни компании, как этот, дают возможность познакомиться, наладить связи междуместными товаропроизводителями и крупными компаниями».

Представители АО «СУЭК-Красноярск» рассказали о правилах регистрации на электронной площадке, основных принципах проведения конкурсных процедур, ответили на вопросы, обменялись с участниками встречи контактами.

\section{ВСТРЕЧА СО СТУДЕНТАМИ}

В рамках Международной научно-практической конференции «Открытые горные работы в XXI веке» состоялась встреча руководителей АО «СУЭК-Красноярск» со студентами Горного института, геологии и геотехнологий Сибирского Федерального университета (СФУ). Цель мероприятия - привлечь перспективных молодых грамотных специалистов для работы на красноярских угледобывающих предприятиях СУЭК.

Компанию представили технический директор АО «СУЭККрасноярск» Евгений Михайлович Евтушенко и начальник управления по персоналу, труду и социальным вопросам Татьяна Вишневская. Они рассказали об особенностях отрасли, о работе угледобывающих предприятий, о том, какие специальности сегодня востребованы на горном производстве, о перспективах профессионального и карьерного роста.

«СУЭК сегодня - лидер в угледобывающей отрасли России. И наша главная задача - сохранять лидерские позиции, развиваться, быть конкурентноспособными и надежными поставщиками «черного золота», - сказал Евгений Евтушенко. - Для достижения этих, без преувеличения, амбициозныхиелей нам необходимы грамотные, инициативные горные специалисты, открытыедля новых знаний».

«Мы будем рады видеть каждого из вас на наших предприятиях на практике, а затем и в рядах наших коллег и сотрудников, - заверила Татьяна Вишневская. - Мы готовы обсуждать условия практики и дальнейшего сотрудничества скаждым индивидуально. Ждем васв нашей компании».

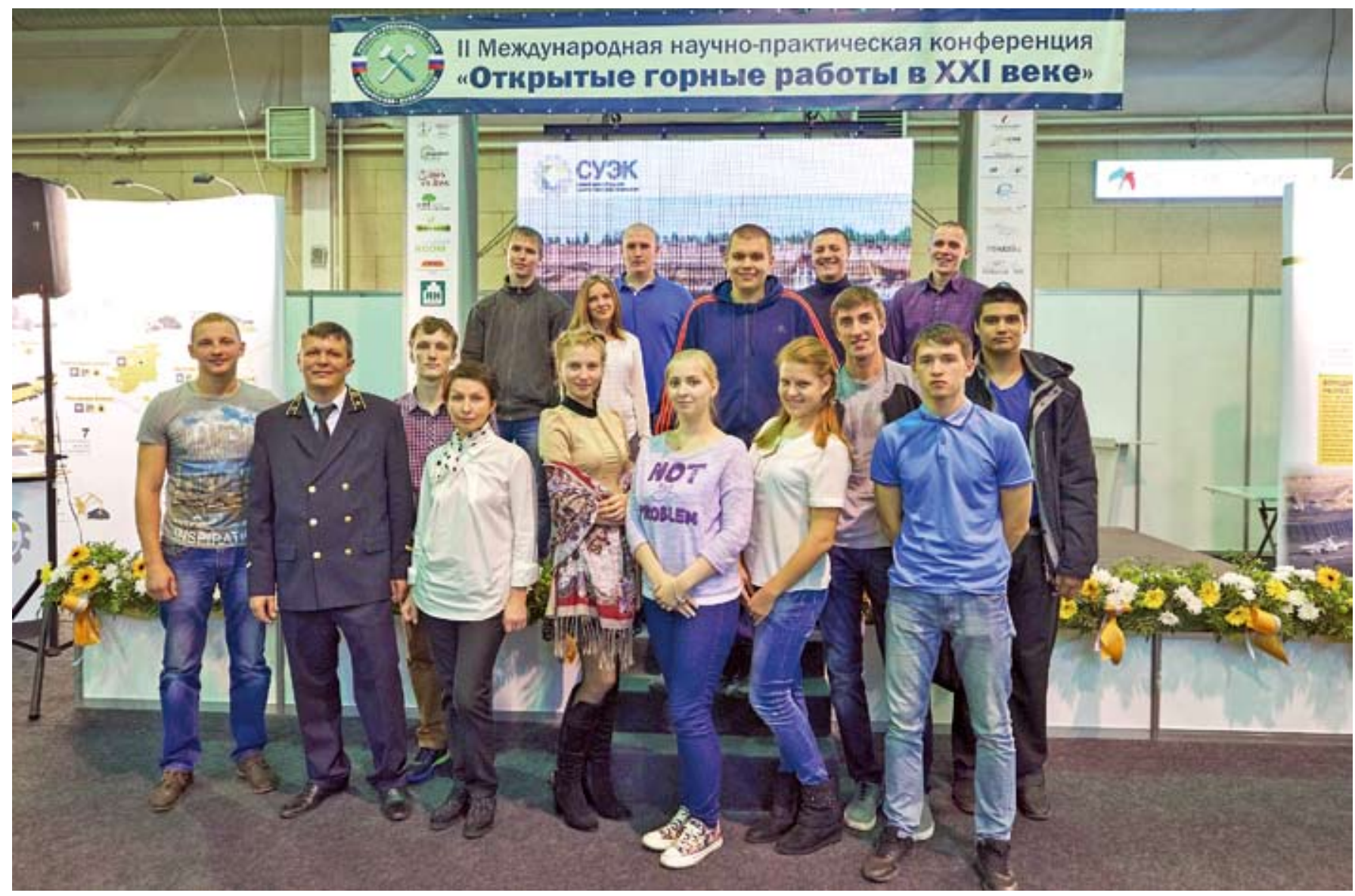


ТЕХНИЧЕСКИЙ ТУР И ОБЗОРНАЯ ЭКСКУРСИЯ

Для гостей и участников были организованы технический тур на крупнейший в России Бородинский разрез и обзорная экскурсия по Красноярску с посещением государственного природного заповедника «Столбы».

Бородинский разрез носит имя легендарного министра угольной промышленности СССР Михаила Ивановича Щадова. Предприятие является флагманом открытой угледобычи в Красноярском крае и России. За время промышленной эксплуатации — с 1949 г. — отгрузили потребителям почти 1 млрд т твердого топлива. Среди потребителей разреза - все ключевые станции Красноярского края, предприятия коммунально-бытовой сферы, жители частного сектора. Гости побывали на ремонтно-механическом заводе, на смотровых площадках разреза, а также на горных работах.

Ну а Красноярские Столбы - удивительный уголокприроды в самом центре Сибири. Место, где вырвавшаяся из недр земли магма застыла каменными изваяниями скал в ожерелье горной тайги.
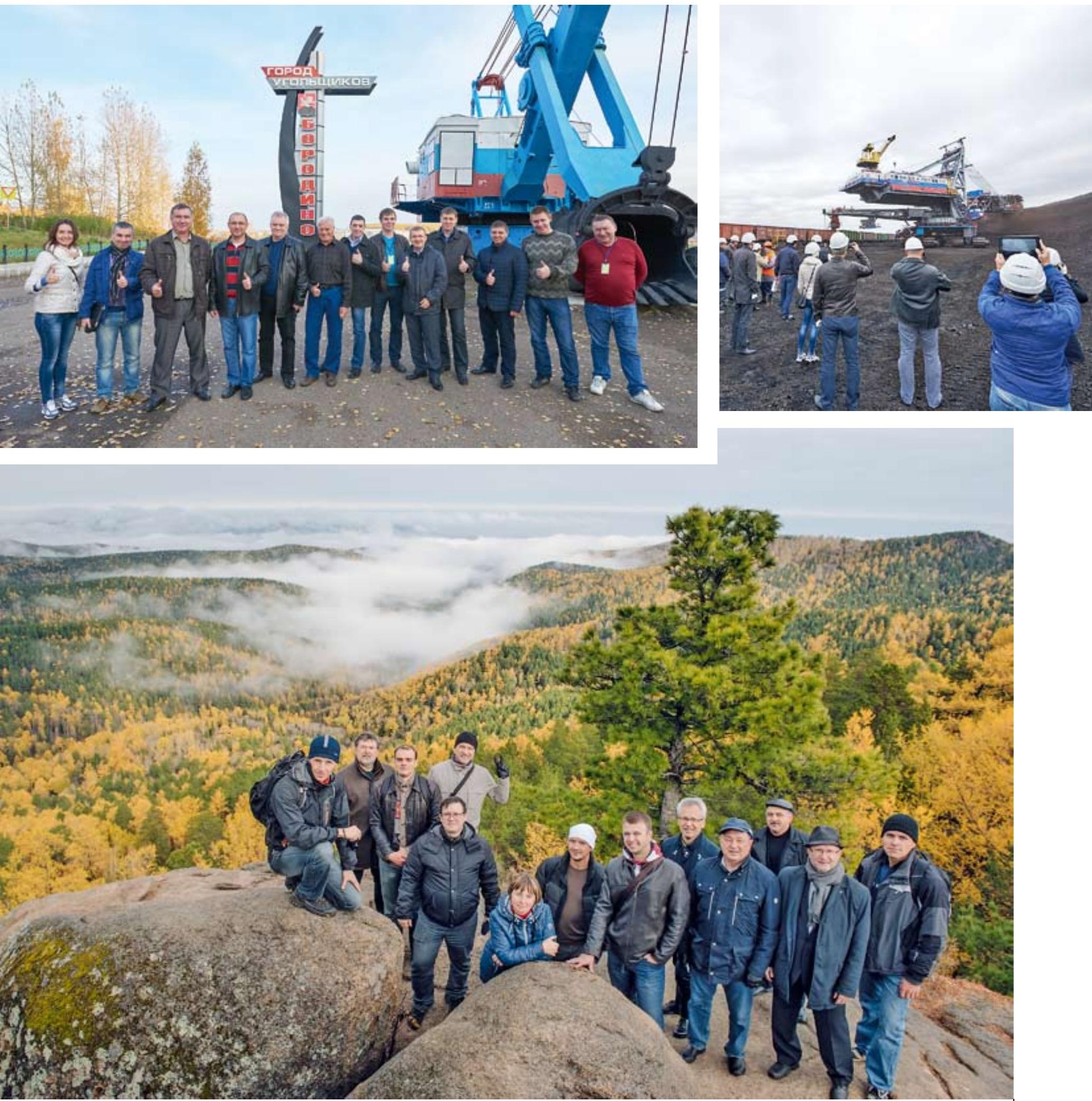

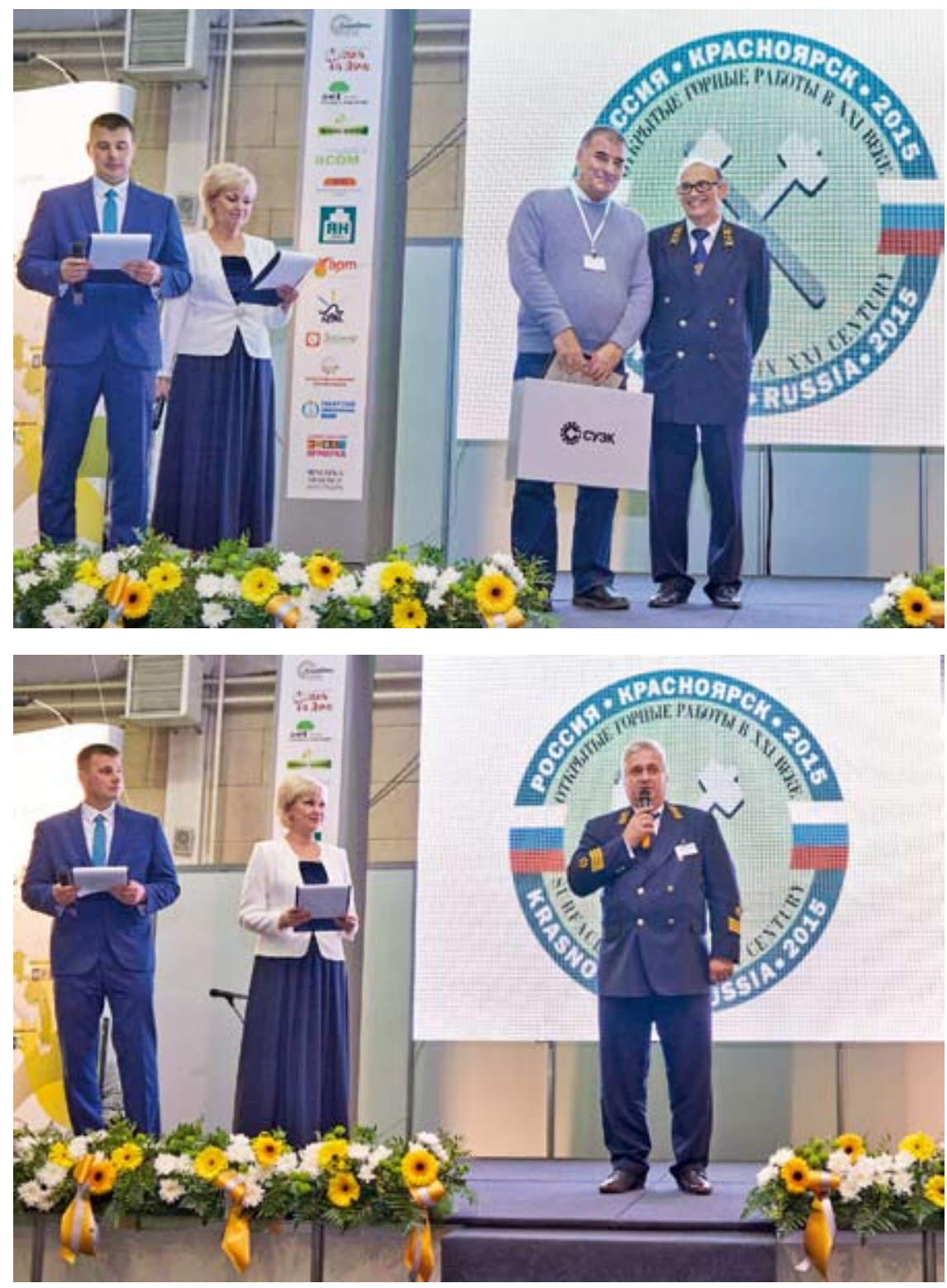

ИТОГИ КОНФЕРЕНЦИИ У УГЛЯ ЕСТЬ БУДУЩЕЕ

Наиболее активные участники дискуссий получили дипломы за подписью исполнительного директора АО «СУЭККрасноярск» Андрея Витальевича Федорова. Именно «СУЭК-Красноярск» выступила в роли принимающей российских и зарубежных гостей стороны и взяла на себя основную организацию Горного форума. Вручая дипломы и ценные подарки, А.В. Федоров еще раз поблагодарил участников за внимание к конференции.

«Самая главная задача нашего форума - вооружить знаниями, разбудить инициативу, дать возможность думать на фактах, примерах, анализе, на совокупности данных и чифр, - обратился к участникам форума заместитель генерального директора $\mathrm{AO}$ «СУЭК» - директор по производственным операциям Владимир Борисович Артемьев. Итоги работы вы подведете, когда вернетесь домой, на свои предприятия. Эти итоги выразятся в кубах вскрыши, тоннах добычи, в безопасности иэффрективности труда, в экономике предприятий. Самое главное, на мой взгляд, что умные, грамотные специалисты обменялись мнениями, идеями и достижениями. Спасибо вам за работу».

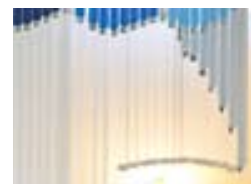

tot
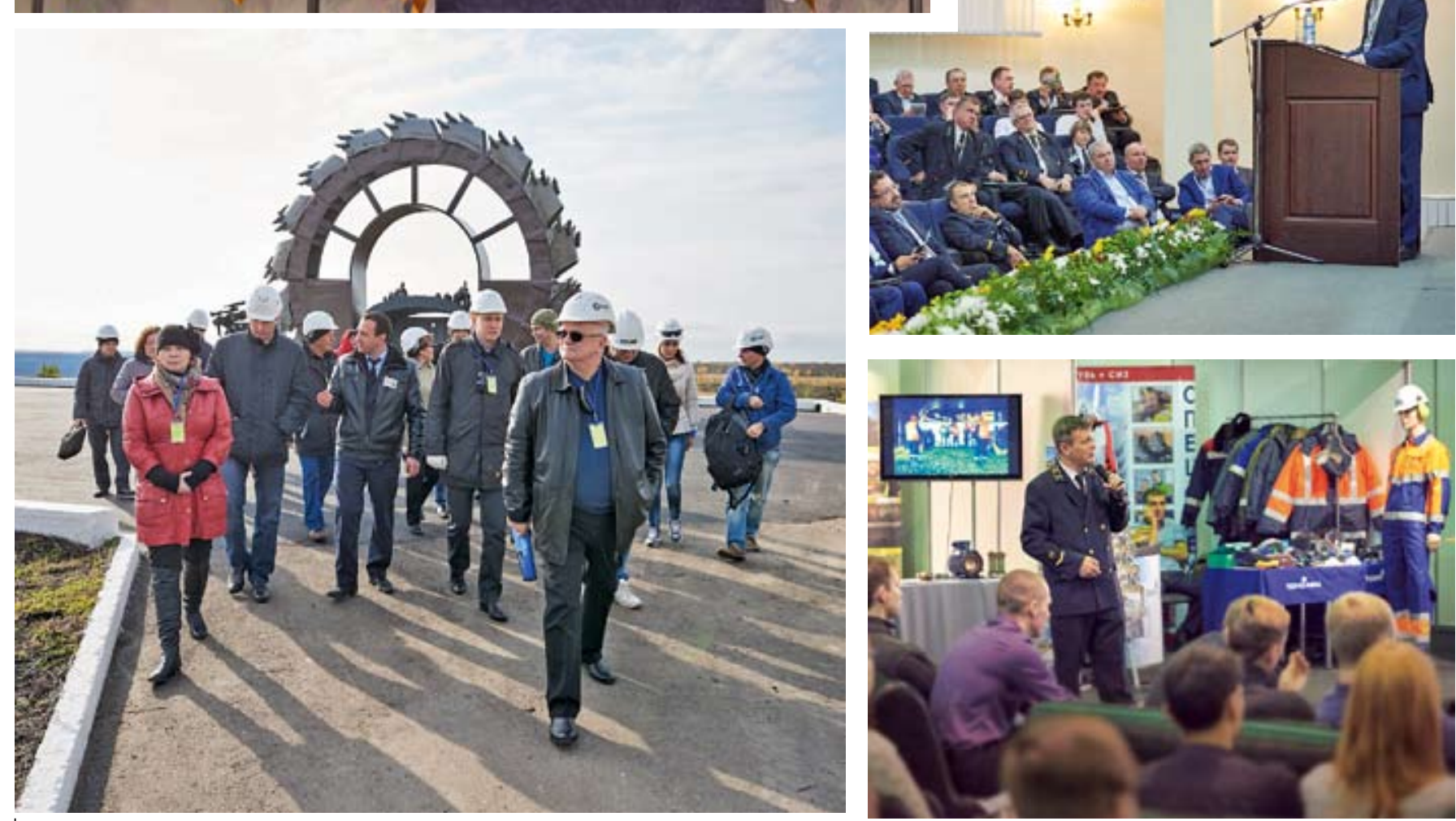
- Поздравляем Вас с наступающим Новьи годом!

Кажкдый из нас ожсидает от Нового года полько лучиего, ведь он обязательно должсеи быть удачнее и радостией предыдущего. В Новом году мы искренне желаем Вам удачи, успехов, зооровья, семейного тепла, любви, радости и исполнения всех жселаний.

Пусть новый год научится у старого только хорошему.
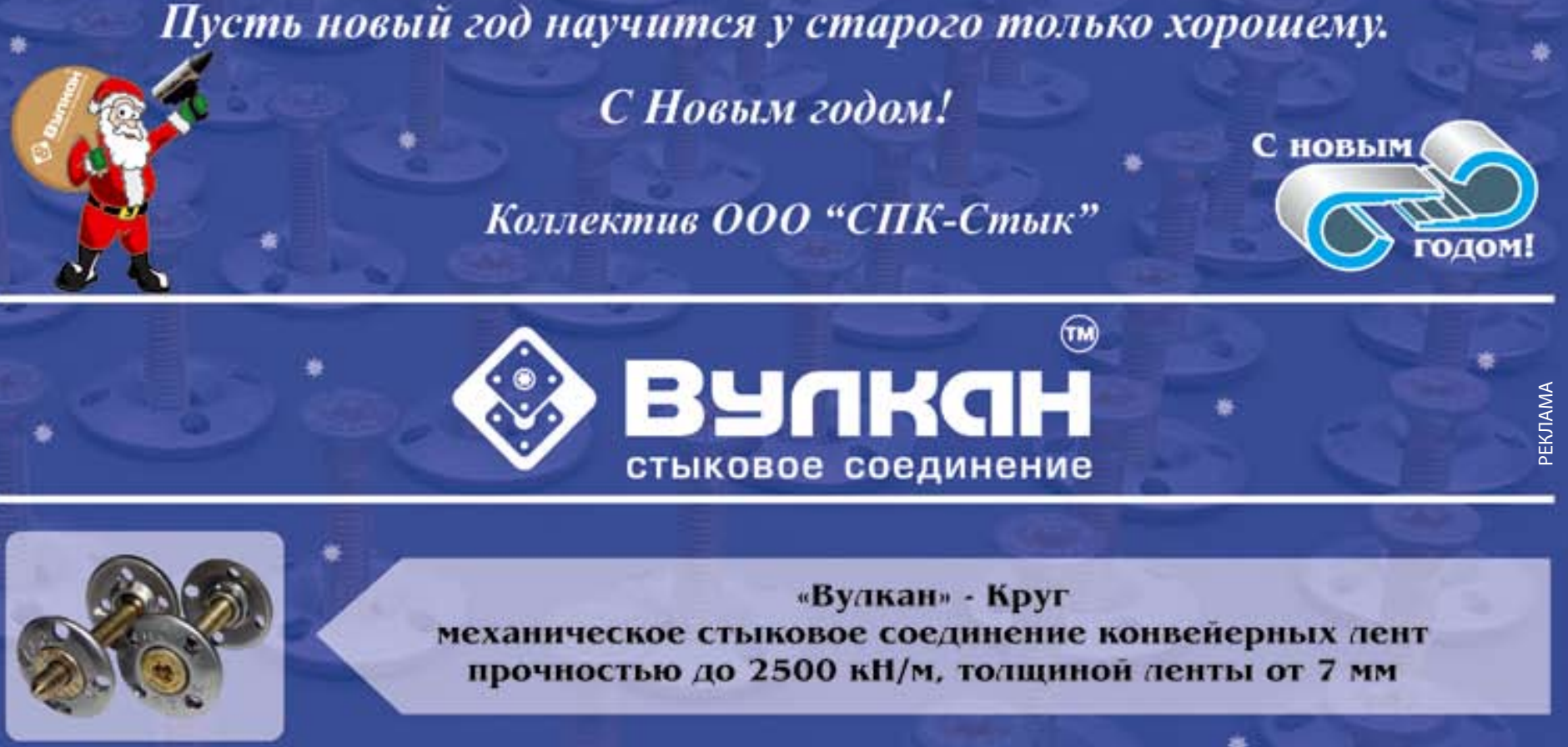

"Вуакан" - Круг

механическое стыковое соединение конвейерных пент

прочностью до 2500 кН/м, толшиной пенты от 7 мм
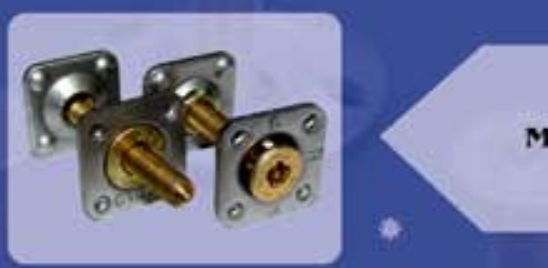

"Вуакан"

механическое стыковое соединение конвейерных аент прочностью до $2500 \mathrm{\kappa H} / \mathrm{M}$
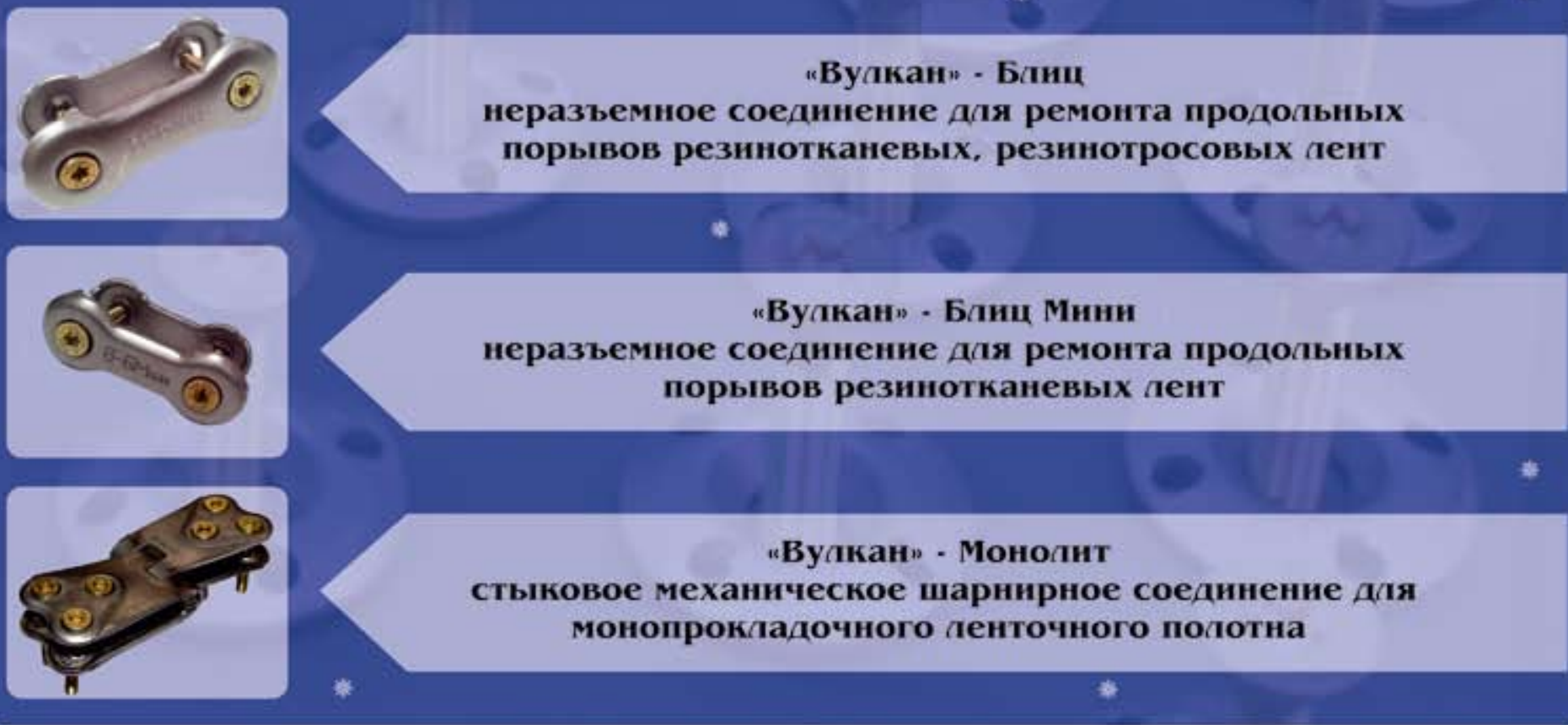

"Вулкан" - Монолит

стыковое механическое шарнирное соединение дая монопрокаадочного аенточного посотна 


\section{Особенности буровзрывных работ} на угольных разрезах Т00 «Богатырь Комир»

DOI: http://dx. doi. org/10.18796/0041-5790-2015-12-18-23

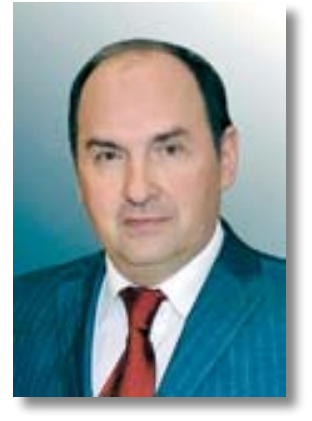

\section{ЩУКИН}

Виктор Константинович

Генеральный директор

ТОО «Богатырь Комир»,

доктор экон. наук,

141209, г. Экибастуз,

Республика Казахстан

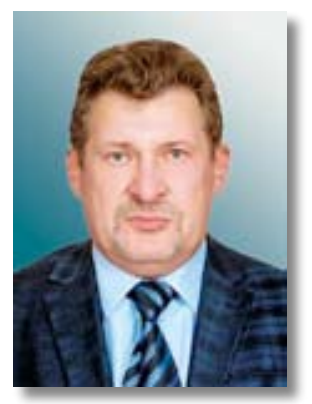

\section{ЗЫКАЛИН}

\section{Александр Васильевич}

Заместитель главного

инженера разреза «Богатырь»,

горный инженер,

141209, г. Экибастуз,

Республика Казахстан

В статье освещены особенности производства буровзрывных работ (БВР) при вскрытии и селективной отработке сверхмощных сложноструктурных экибастузских угольных пластов, а также улучшения эффективности БВР при неуклонном углублении горных работ.

Ключевые слова: бурение скважин, массовые взрывы, взрывчатые материалы (ВM), крепость пород, забойка, обводненность, газонасыщенность.

Экибастузские угли относятся к категории очень крепких и весьма труднообогатимых, поставляются потребителю в рядовом виде для использования в пылевидном состоянии. Самым мощным и самым сложным в структурном отношении является пласт 3 - средняя мощность $102 \mathrm{M}$, в том числе суммарная мощность породных прослоев 14 м толщиной от 1 см до нескольких метров. Средняя зольность кондиционного угля пласта 3 составляет $47 \%$. Пласты 1 и 2 суммарной мощностью до 70 м относительно простого строения и отрабатываются в основном валовым способом, селективной выемке подлежит только междупластье 1-2 мощностью 4-5 м. Зольность кондиционного угля пласта $1-35 \%$, пласта $2-36,5 \%$.

Запасы рядового угля на разрезах «Богатырь» и «Северный» подсчитаны по кондициям: по мощности $m \geq 4$ м, по зольности $A^{d} \leq 60 \%$ для пластов 1 и 2 и $A^{d} \leq 53 \%$ для пласта 3. Углепородные комплексы, превышающие указанные параметры отнесены к внутренней вскрыше и подлежат селективной выемке. Порядок селективной отработки кондиционных и некондиционных комплексов определяется с помощью геолого-технологической карты (ГТК), составляемой на основе бороздового опробования конкретного угольного уступа (рис. 1).

Непременным условием для селективной выемки угля и породы является сохранение геологической картинки в забое после взрывных работ (ВР). Угольные пласты 1, 2, 3 имеют средневзвешенную сопротивляемость сжатию $230 \mathrm{kr} / \mathrm{cm}^{2}$ и отрабатываются исключительно с применением ВP (рuc. 2).

Для обеспечения указанного условия на разрезах Экибастуза применяются взрывные работы «на сотрясание», целью которых является ослабление массива для эффективной работы добычных экскаваторов. Удельный расход

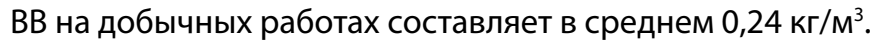
Переход на разрезах ТОО «Богатырь Комир» с 2011 г. на добычу угля ковшовыми экскаваторами с использованием и усреднением угля в штабелях позволил стабилизировать качество угля как в течение года, так и по годам в целом. 3а 2011-2014 гг. потребителям отгружено 164,4 млн т товарного угля. Вскрышные работы производятся экскаваторами ЭКГ-12 УС, ЭКГ-10Ус, ЭКГ-8У. Работы по зачистке угля выполняют экскаваторы ЭШ-13/50 (рис. 3).

Каменноугольные отложения внешней вскрыши бассейна (см. таблицу) представлены, в основном песчаниками, алевролитами, аргиллитами и переслаиванием вышеуказанных разностей.

\section{Распределение пород внешней вскрыши по литологическим разностям, \%}

\begin{tabular}{|c|c|c|}
\hline Наименование & Доля участия, \% & Крепость, МПа \\
\hline Покровные отложения (песок, суглинок) & 1,1 & $10-20$ \\
\hline Уголь (нерабочие пласты) & 1,6 & $20-25$ \\
\hline Углистые сланцы & 2,4 & $16-20$ \\
\hline Углистая порода & 2,9 & $20-25$ \\
\hline Песчаник & 38,2 & $60-80$ \\
\hline Алевролит & 27,5 & 54-57 \\
\hline Аргиллит & 15,1 & $30-50$ \\
\hline Переслаивание пород & 11,2 & $25-53$ \\
\hline
\end{tabular}




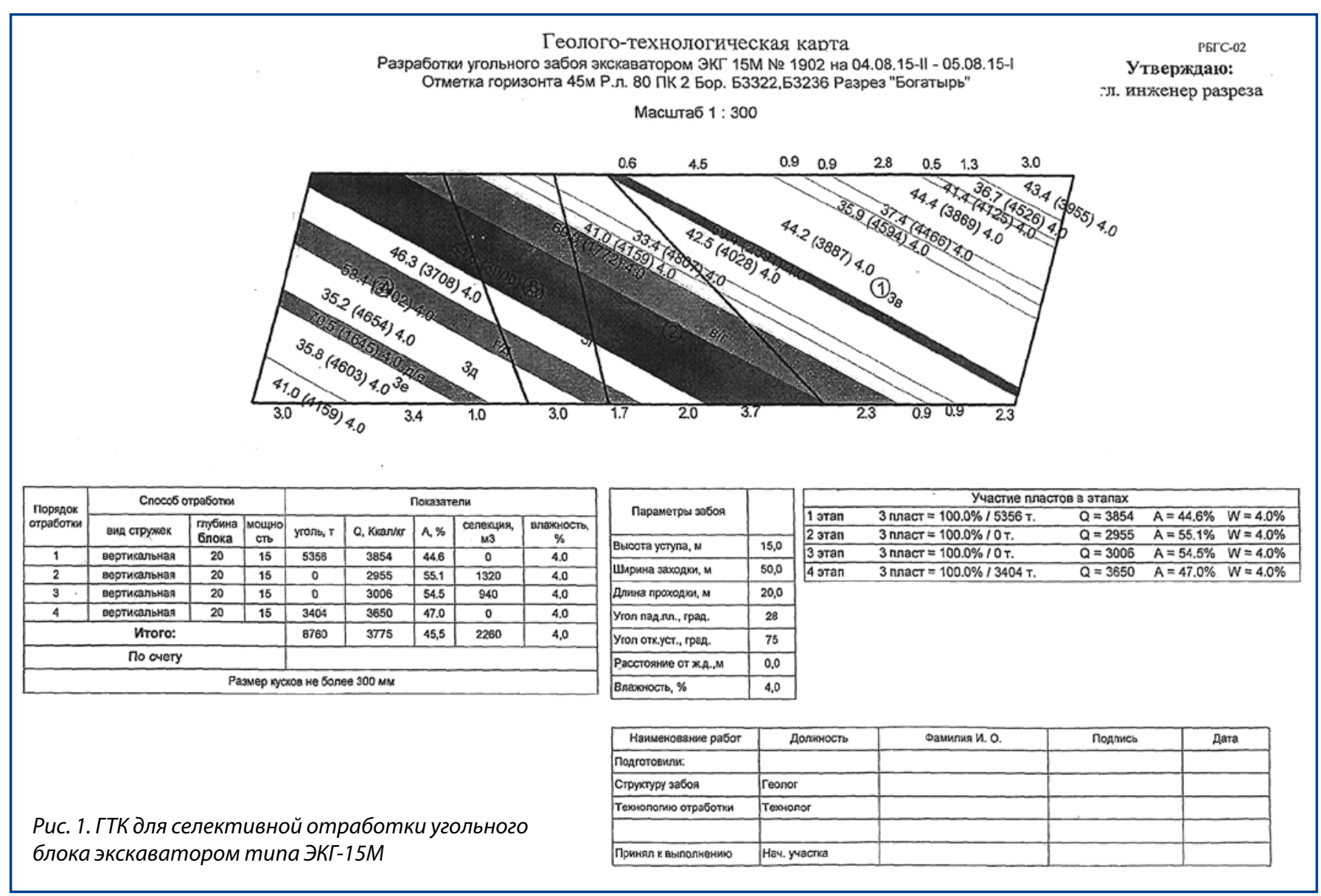

Эти породы наиболее крепкие и составляют $80,8 \%$ общей массы покровного комплекса отложений внешней вскрыши, среди которых можно отдельно выделить песчаники и алевролиты крепостью от 54 до 80 МПа.

Для производительной работы экскаваторов на вскрыше при погрузке в железнодорожный и автомобильный транспорт буровзрывные работы должны обеспечивать нормальное рыхление с равномерным дроблением массива. В отличие от угольного забоя допускается развал горной массы, ширина которого зависит от крепости пород. На песчаниках ширина развала составляет 1,5 высоты

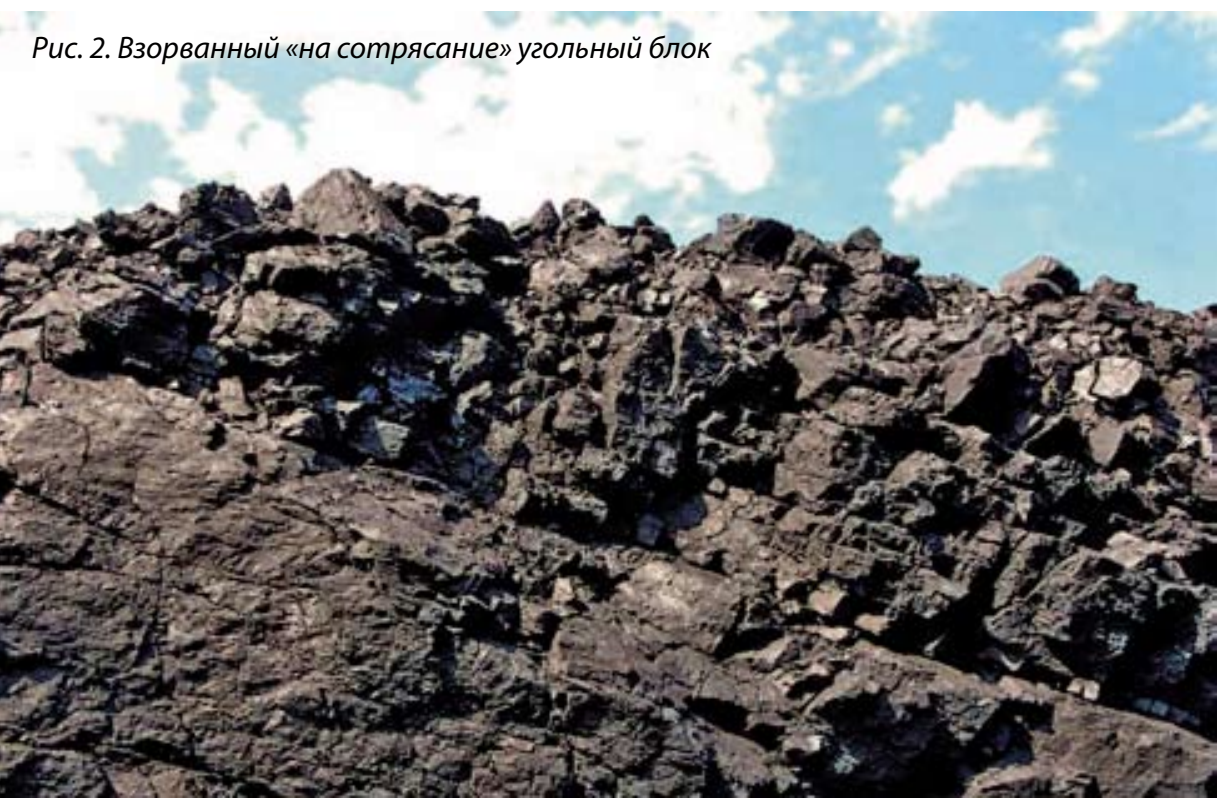
отрабатываемого уступа, на менее крепких породах развал соответствует высоте забоя.

Рассредоточение скважинного заряда на вскрыше осуществляют созданием воздушного промежутка при помощи скважинных затворов. Создание воздушного промежутка в скважинном заряде взрывчатого вещества способствует увеличению КПД работы взрыва, снижает удельный расход ВВ, сокращает переизмельчение породы, пылеобразование и расход забоечного материала. Основной заряд размещается также, как на угле, а за тем над ним, на высоте, соответствующей конструкции скважинного

заряда, подается ВВ дополнительного заряда с установкой в него боевика и производится забойка скважинного заряда (рис. 4).

Для дробления верхней части уступа, представленной более крепкими породами, чем нижняя часть, бурятся промежуточные скважины. Дно промежуточных скважин должно располагаться в основании крепкого прослоя. Рассредоточение скважинных зарядов, состоящих из различных типов ВВ на угле и вскрыше с применением разных средств, имеет цель, за счет более равномерного расположения зарядов ВВ во взрываемом блоке, снизить 

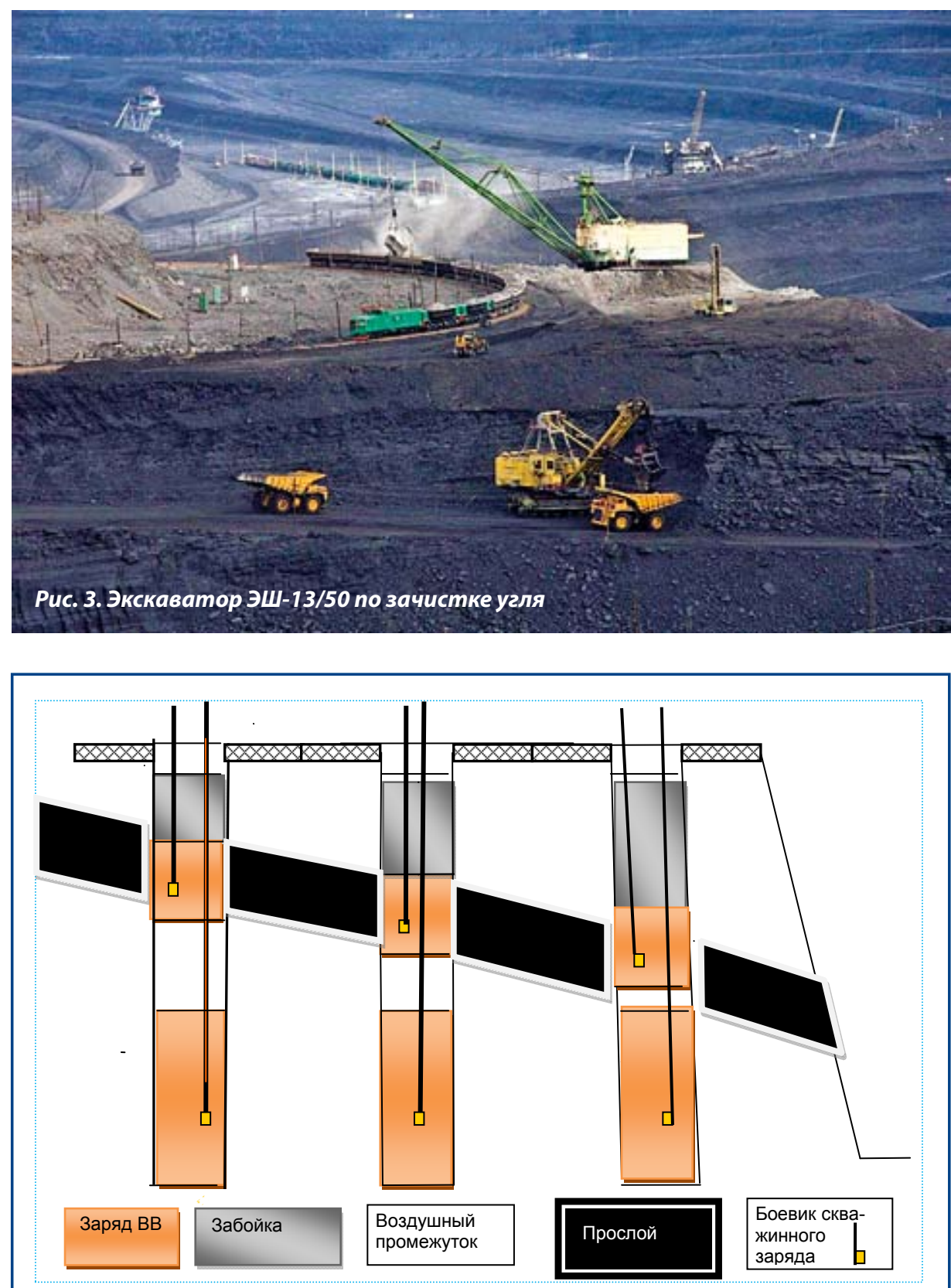

Рис. 4. Конструкция скважинного заряда с воздушным промежутком на вскрыше

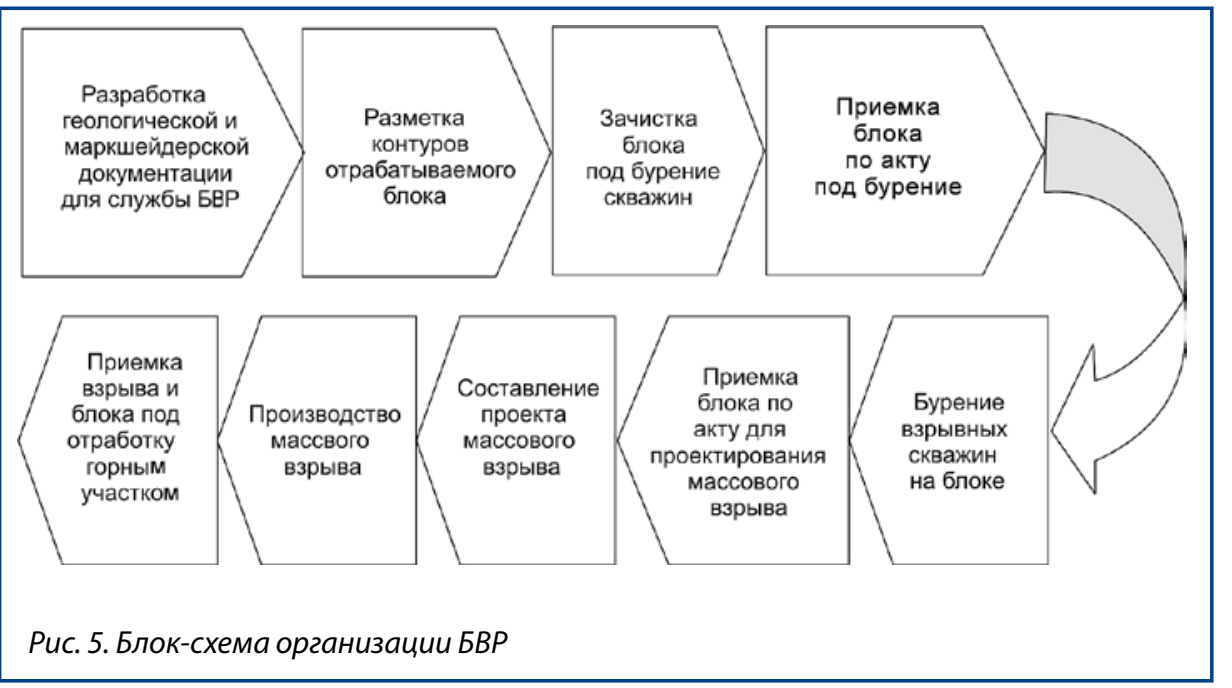

его удельный расход и наиболее компактно разместить взорванную горную массу в забое.

Для достижения требуемых параметров взрывной подготовки вскрышного и угольного массива в компании «Богатырь Комир» разрабатываются различные организационно-технические мероприятия по элементам буровых и взрывных работ. Эффективность буровых работ обеспечивается выбором нового типа бурового оборудования и его эффективным использованием.

В период с 2006 по 2014 г. на разрезах компании осуществлено перевооружение парка буровых станков. Из эксплуатации выведены 23 электрических буровых станка, в том числе типа СБР-160 - шесть единиц и СБШ-200/60 - 17 единиц. Взамен этого приобретены девять мобильных буровых станков типа DM-45 и DML, производства компании Atlas Copco. Различные параметры буровых работ в зависимости от типа экскаватора, крепости слагающих уступ пород, обводненности забоев определили применение буровых станков DM-45 с диаметром бурения скважин 175 мм - на угле, а станков DML с диаметром буровых скважин 220 мм - на вскрыше. Кроме замены парка буровых машин произошло изменение режима буровых работ. В настоящее время на разрезах буровые работы производятся в непрерывном режиме. При этом в процессе освоения нового оборудования, повышения квалификации обслуживающего персонала идет постоянный рост часовой производительности буровых станков.

Наряду с этим, с целью достижения максимального эффекта при производстве буровых и взрывных работ разработан и строго исполняется алгоритм организации и взаимодействия между участками и службами разреза. Блок-схема организации БВР на разрезах компании представлена на рис. 5.

Целью данного алгоритма является обеспечение каждого взрываемого блока технической документацией на основе достоверных 


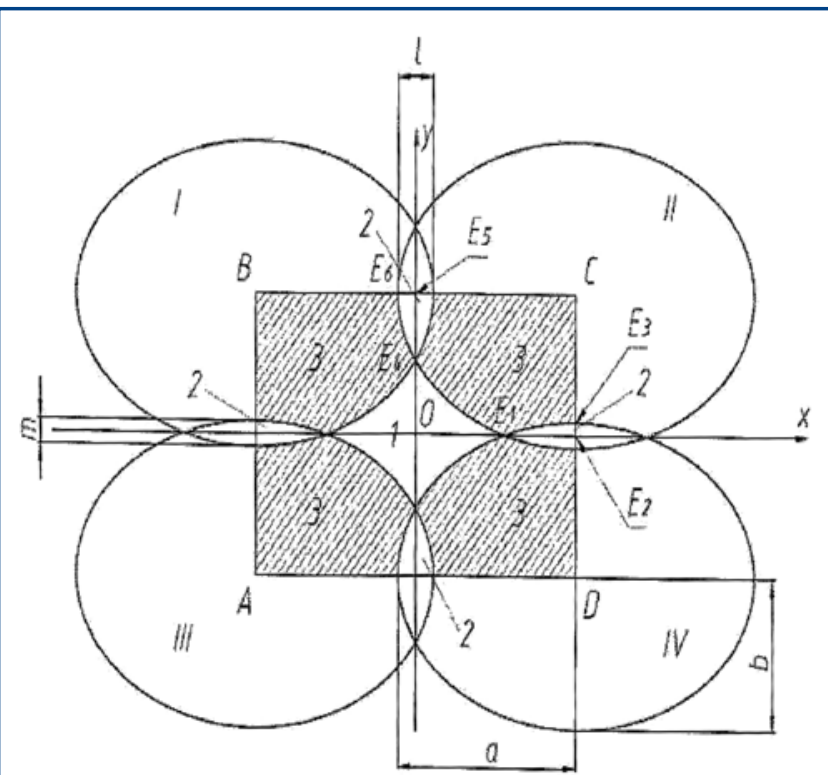

Рис. 6. Схема к определению величин полезной и нерабочей площадей скважин зарядов, расположенных по прямоугольной сетке

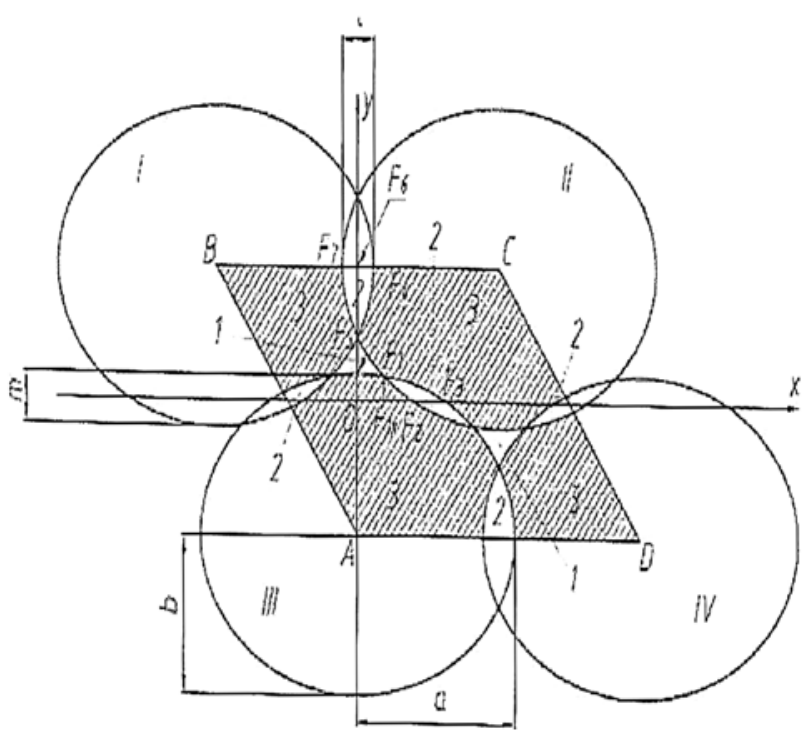

Рис. 7. Схема к определению величин полезной и нерабочей площадей скважин зарядов, расположенных по шахматной сетке горно-геологических данных с применением эффективных методов БВР и их безусловное исполнение.

Для буровых работ разрабатывается технологическая карта (наряд-паспорт) на основе сборника типовых проектов производства БВР, в котором содержится более 20 вариантов буровзрывной подготовки забоев, соответствующих силовым и линейным параметрам горного массива, а также с учетом других факторов: обводненность забоя, крепость слагающих уступ пород, угол их залегания, расстояние до различных коммуникаций и иных объектов, находящихся в зоне возможного воздействия взрыва. В соответствии с указанными факторами выбирается диаметр скважин, угол и направление их наклона, расстояния между скважинами в ряду и рядами, расположение скважин относительно друг друга. Для производства взрывных работ разрабатывается проект массового взрыва с учетом типа применяемых ВB, величины скважинного заряда, удельного расхода ВВ на единицу объема горной массы.

Результаты проведения массового взрыва во многом зависят от расположения взрывных скважин относительно друг друга. На разрезах в основном применяется прямоугольное расположение взрывных скважин во взрываемых блоках (рис. 6), а с 2014 г. в забоях, сложенных менее крепкими породами, размещают взрывные скважины в «шахматном» порядке (рис. 7).

В обоих вариантах (см. рис. 6, 7) при взрыве зарядов образуются три вида областей разрушения массива:

1 - непроработанная и образованная между контурами воронок от взрыва четырех ближайших зарядов;

2 - образованная вследствие наложения воронок от двух соседних зарядов по большому и малому радиусам зоны разрушения;

3 - проработанная действием взрыва четырех зарядов; $a, b$ - радиусы большой и малой осей воронок дробления; I, $m$ - величины перекрытия воронок дробления по горизонтали и вертикали; $A, B, C, D$ - оси скважинных зарядов; I, II, III, IV - порядковые номера зон действия зарядов.

Расположение скважин в подготавливаемом к взрыву блоке в «шахматном» порядке позволило увеличить в 1,5 раза расстояние между скважинами в ряду при сокращении всего в 1,2 раза расстояния между рядами. При этом выход горной массы с 1 м взрывной скважины, в сравнении с прямоугольным расположением скважин, увеличился на 20-25\%. Экономический эффект за два месяца 2014 г. составил 1 млн тенге, ожидаемый эффект в 2015 г. - не менее 15 млн тенге (82 тыс.дол. США).

Кроме оптимизации объема бурения на разрезах ведется работа по сохранению пробуренных скважин при производстве взрывных работ из-за сдвига слагающих уступ пластов, то есть их подбоя. Ранее на разрезах пропускали в каждом ряду по одной скважине и начинали бурить следующий блок. Зачастую созданная межблочная перемычка не давала результата. Необходимость бурения взрывных скважин рядом с подготовленным к взрыву блоком обусловлена соотношением бурового и горно-выемочного оборудования, когда одним буровым станком обеспечиваются необходимые объемы бурения. При этом в забоях находятся до четырех экскаваторов. Расчетом сейсмического воздействия подрыва скважинных зарядов во взрываемом блоке на разрезах определен размер минимальной межблочной перемычки, который препятствует подбою взрывных скважин в соседнем блоке. После производства ВР межблочная перемычка разбуривается в составе следующего блока. В результате в 2014 г. объем подбитых скважин сократился до трех раз. Динамика подбоя взрывных скважин приведена на рис. 8.

За счет уменьшения объема потерь скважин, сокращение непроизводительных затрат на разрезах в 2014 г. составило 15,872 млн тенге (87тыс.дол. США), при том что 


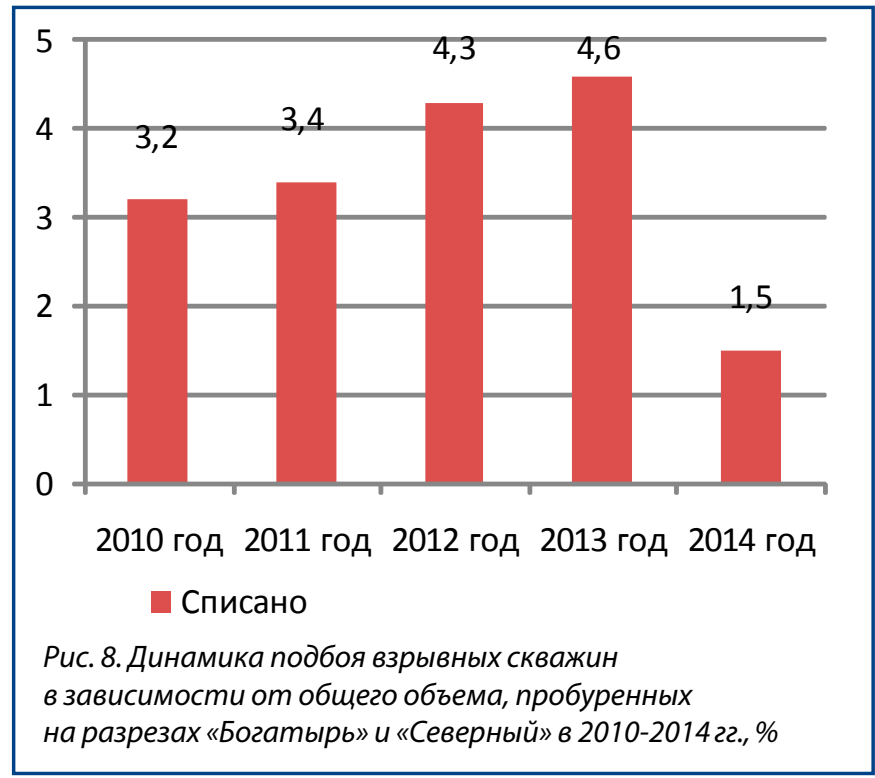

затраты по этому элементу в 2013 г. составили 36,8 млн тенге (245 тыс. дол. США).

При производстве взрывных работ на разрезах «Богатырь» и «Северный» в качестве основного заряда используются взрывчатые вещества (BВ), изготавливаемые непосредственно на местах производства работ. Неводоустойчивые ВB на основе аммиачной селитры типа игданит (ANFO) изготавливаются собственными силами с использованием зарядных машин М3-3Б-12-041 и МС315 ВП-014. Объем использования игданита на взрывных работах разрезов составляет $62 \%$ от общего объема потребляемых ВВ. Оставшиеся $38 \%$ - это качаемые водоустойчивые взрывчатые вещества (KBB) Rioflex и Fortis Extra 70, производства ТОО «Максам Казахстан» и АO «Орика Казахстан», изготавливаемые и размещаемые во взрывных скважинах названных подрядчиками при помощи смесительно-зарядных машин (С3М) Flexi Truck и Trade Star под руководством взрывного персонала компании.

Качаемые взрывчатые вещества, заряжаемые под «столб» воды в скважине, обеспечивают формирование колонки заряда за достаточно короткий промежуток времени с минимальными трудозатратами, что выгодно их отличает от применявшихся ранее на разрезах патронированных ВВ на основе аммиачной селитры, формирование заряда из которых было затруднено изза большой плотности соленой воды в скважинах. Высокая механизация процесса заряжания и сравнительная дешевизна качаемых взрывчатых веществ в сравнении с тротилосодержащими гранулированными также явились аргументами в пользу замены последних на качаемые, хотя в сравнении с простейшими неводостойкими ВВ использование КВВ более затратно. Применение КВВ на угольных забоях в зонах метановыделения исключило случаи возгорания угля после производства взрывных работ.

Одним из показателей, влияющих прежде всего на качество взрывной подготовки, является удельный расход ВВ на единицу объема взорванной горной массы. На разрезах удельный расход на угле составляет от 190 до 280 кг на 1000 куб. м, на вскрыше, в зависимости от крепости пород, колеблется от 350 до 550 кг. Снижение удельного расхода без ущерба качеству проработки массива всегда является приоритетной целью на разрезах.

Для инициации ВВ длительное время в качестве инициирующего заряда использовались шашки Т-400Г из прессованного тротила весом 400 г. Токсичность чистого тротила и высокая стоимость изделий на его основе способствовали замещению Т-400Г капсюлечувствительными патронированными эмульсионными взрывчатыми веществами различного веса от 1 до 2 кг. Как показывает опыт применения патронов данного типа, высокая скорость детонации данных изделий обеспечивает полное срабатывание скважинного заряда при уменьшении веса патрона. В настоящее время АО «Орика Казахстан» изготавливает патроны Senatel Magnum весом 500 г, оптимальных длины и диаметра, которые используются для изготовления боевиков.

В 2010 г. доля капсюлечувствительных патронов в общем объеме ВВ составляла 1,8\%, а в 2014 г. в результате использования патронов уменьшенного веса была сокращена до 0,76\% в объеме потребляемых ВВ. Затраты на капсюлечувствительные ВВ при подрыве одного скважинного заряда на разрезах сокращены в 1,7 раза. В 2014 г. они снижены на 22,85 млн тенге (127 тыс. дол. США).

В обводненных забоях на вскрыше для равномерного размещения заряда в скважинах, повышения качества дробления горной массы и сокращения объема потребления качаемых взрывчатых веществ используются устройства по подаче гидроизолирующего рукава (УПР) во взрывные скважины. Конструкция обычного заряда без использования УПР приведена на рис. 9, с применением УПР - на рис. 10.

Технология УПР предполагает формирование заряда с оптимальным диаметром, меньшим диаметра скважины, без уменьшения расстояний между скважинами в ряду и рядами скважин. В этом случае вследствие изменения характера газодинамических процессов в скважинах изменяется характер действующего поля напряжений пород. Кроме того, водная оболочка заряда способствует улучшению протекания детонационного процесса, а также, вследствие испарения воды, увеличению объема газообразных продуктов взрыва. В 2014 г. за счет внедрения технологии УПР сокращено потребление качаемых взрывчатых веществ на 145 т. Фактический удельный

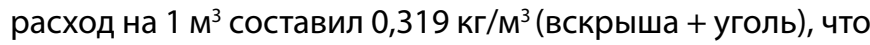
на $2 \%$ ниже удельного расхода 2013 г. В денежном выражении эффект от применения технологии УПР составил 14 млн тенге (78 тыс.дол. США).

Одним из критериев оценки эффективности буровзрывной подготовки на вскрыше является объем негабаритных кусков горной массы в объеме взорванного забоя. За счет создания так называемых «подпорных» стенок в забоях, сложенных крупноблочными породами, и применения перечисленных способов рассредоточения зарядов добились снижения выхода негабарита в 1,4 раза в 2014 г. в сравнении с предыдущими годами. Эти мероприятия позволили отказаться от разделки негабарита методом шпуровых зарядов как источника повышенной опаснос- 


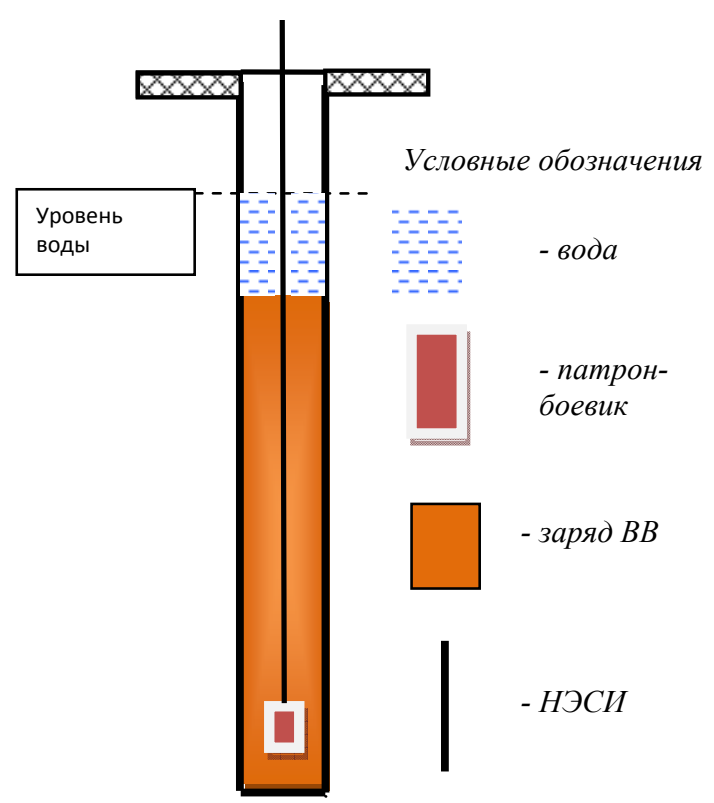

Puс. 9. Конструкция заряда без использования УПР

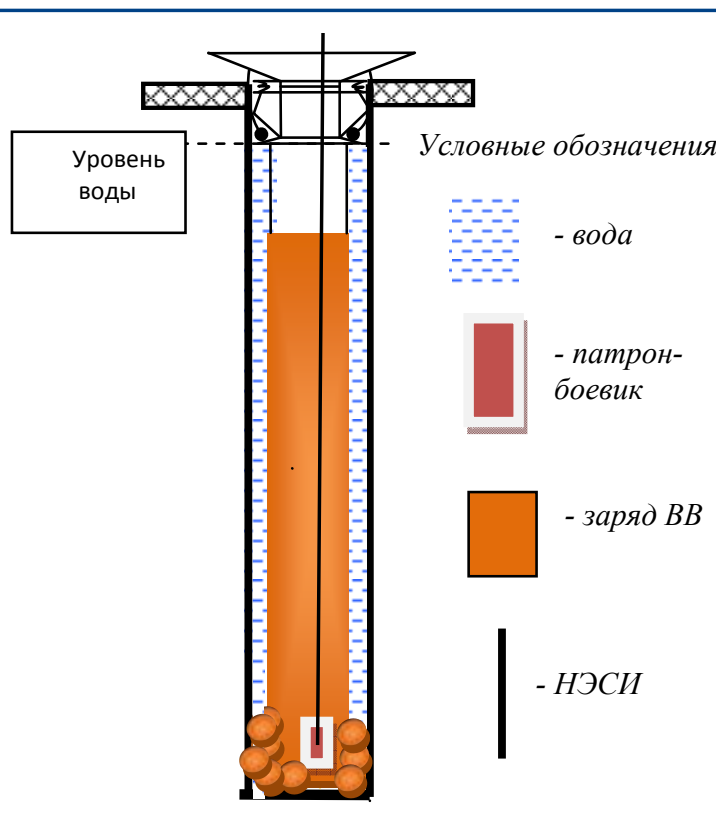

Рис. 10. Конструкция заряда с использованием УПР ти и полностью перейти на его механическую разделку гидромолотом, установленным на строительном экскаваторе.

Для мобилизации творческого, трудового потенциала, направленного на снижение затрат на буровзрывные работы и повышения производительности бурового оборудования между администрацией компании и участками буровых и взрывных работ на 2015 г. заключен договор. В договоре установлены следующие техникоэкономические показатели: объем бурения на угле и вскрыше, объем взорванной горной массы, производительность бурового станка на угле и вскрыше, общие затраты на 1 куб. м ВГМ, общий удельный расход ВВ, подбой скважин. При условии выполнения участками пунктов договора установлены критерии премирования: за рост производительности бурового оборудования на $5 \%-5 \%$ месячной тарифной ставки, оклада в год, за каждый процент роста производительности премия увеличивается на 0,7\%, но не более $12 \%$; за экономию затрат на взрывчатые материалы и буровые работы на 1 куб. м горной массы - до $10 \%$ от суммы снижения затрат по данным бухгалтерского учета на весь объем взорванной горной массы при условии недопущения работниками браков в работе и нарушений технологического процесса.

Все вышеперечисленные мероприятия позволяют без радикальных подходов и изменений в буровзрывных работах достичь значительных технических и экономических результатов эффективной деятельности угледобывающего предприятия ТОО «Богатырь Комир».

UDC 622.271:622.233: :622.235(574) @ V.K. Schukin, A.V. Zykalin, 2015

SURFACE MINING

ISSN 0041-5790 (Print) • ISSN 2412-8333 (Online) • Ugol' — Russian Coal Journal, 2015, № 12, pp. 18-23

Title

SPECIFIC FEATURES OF DRILLING AND BLASTING OPERATIONS AT THE COAL STRIP MINES OF “BOGATYR KOMIR" LLP

DOI: http://dx.doi.org/10.18796/0041-5790-2015-12-18-23

Authors

Schukin V.K. ${ }^{1}$, Zykalin A.V. ${ }^{1}$

1 "Bogatyr Komir" LLP, Ekibastuz, 141209, the Republic of Kazakhstan

Authors' Information

Schukin V.K., Doctor of Economic Sciences, General Director

Zykalin A.V., mining engineer, Deputy Chief Engineer of "Bogatyr" open-pit mine

\section{Abstract}

The article covers the specific features of drilling and blasting operations (DBO) during the opening and selective mining of extra-thick Ekibastuz coal layers with complex structure and DBO efficiency enhancement during the steady deepening of mining.

Keywords

Blast-hole drilling, major blasts, blasting materials (BM), rock strength, stemming, water content, gas saturation. 


\title{
Совершенствование способов буровзрывной
}

\section{подготовки пород на предприятиях ОАО «УК «Кузбассразрезуголь»}

\author{
DOI: http://dx. doi. org/10.18796/0041-5790-2015-12-24-31
}

\author{
МАТВА Станислав Вячеславович \\ Заместитель директора - технический директор \\ ОАО «УК «Кузбассразрезуголь», \\ 650054, г. Кемерово, Россия, e-mail: matva@kru.ru
}

\section{КОКИН Сергей Вадимович}

Генеральный директор

ООО «Кузбассразрезуголь-Взрывпром», канд. техн. наук, 650054, г. Кемерово, Россия, e-mail: kokinsv@kruvp.kru.ru

\section{литвин Юрий Иванович}

Начальник управления планирования

горного производства ОАО «УК «Кузбассразрезуголь», канд. техн. наук, 650054, г. Кемерово, Россия,

e-mail:litvinui@kru.ru

\section{ПРОТАСОВ Сергей Иванович}

Генеральный директор

ООО «Новачионная фирма «КУЗБАСС-НИИОГР», канд. техн. наук, 650054, г. Кемерово, Россия,

e-mail:protasov@kuzbass-niiogr.ru

\section{КОРНЕВ Геннадий Николаевич}

Начальник отдела по БВР

ОАО «УК «Кузбассразрезуголь»,

650054, 2. Кемерово, Россия, e-mail:kornev@kru.ru

\section{ФЕДОТЕНКО Виктор Сергеевич}

Заместитель генерального директора

ООО «Строймаш», канд. техн. наук,

650036, г. Кемерово, Россия,

e-mail: victorfedotenko@gmail.com

Выполнен анализ изменений, произошедших на разрезах Кузбасса за последние 15 лет. Разработана программа испытания и внедрения комплекса организационно-технических решений, позволяющих подготавливать горную массу буровзрывным способом в требуемом объеме без превышения допустимых величин негативного воздействия взрыва, а также обеспечивающих рациональное качество взрывного дробления горной массы с одновременным снижением удельного расхода взрывчатых веществ. Всего выполнено более 600 экспериментальных взрывов. Испытаны способы скважинной забойки, рассредоточения заряда в скважине и способы создания промежутка в донной части скважины. Внедрение испытанных способов в период с 2013 по 2015 г. в филиалах ОАО «УК «Кузбассразрезуголь» обеспечило экономию 62,8 тыс. т взрывчатых веществ и позволило добиться снижения негативного воздействия на окружающую среду.
Ключевые слова:открытые горные работы, буровзрывные работы, конструкция заряда, энергия взрыва, скважинная забойка, рассредоточение, воздушный промежуток, перебур, окружающая среда, производительность оборудования

\section{ВВЕДЕНИЕ}

Добыча полезных ископаемыхявляется одним из начальных звеньев цепи формирования добавочной стоимости при производстве товаров и услуг. На фоне динамичного развития альтернативных источников энергии уголь как один из традиционных видов топлива, по-прежнему является и на долгие годы останется востребованным. При этом технология извлечения угля непрерывно претерпевает изменения - горнодобывающая промышленность последовательно воспринимает все достижения науки и техники. За последние несколько десятилетий кардинально изменился облик отрасли. Так, например, до 1990-хгг. основной объем угля добывался подземным способом. Сегодня же, напротив, доля угледобычи открытым способом в Кузбассе уже составляет $63 \%$ и продолжает расти. Это объясняется сравнительной безопасностью, а также широким диапазоном технических возможностей современных средств механизации при работе на поверхности.

На долю Кемеровской области приходится значительный объем запасов высококачественных коксующихся и энергетических углей, при этом за последние 15 лет добыча угля в Кузбассе значительно выросла и преодолела рубеж в 200 млн т в год. Это произошло не только благодаря запуску ряда новых угледобывающих предприятий, но прежде всего за счет совершенствования технологического цикла на уже существующих. При этом добыча угля открытым способом осуществляется при изменяющихся в широком диапазоне горно-геологических условиях ведения горных работ, совершенствовании технологии и организации, развитии экономических способов управления производством. Все больше вовлекаются в разработку глубинная и нагорная части карьерных полей разрезов. Осваиваются новые участки месторождений, дорабатываются старые.

На протяжении длительного времени лидирующее положение в отрасли стабильно занимает ОАО «УК «Кузбассразрезуголь». На 13 разрезах шести филиалов компании в 2014 г. добыто 43473 тыс. т угля, в 2015 г. планируется добыть 44325 тыс. т, что составит порядка $23 \%$ общей добычи и $34 \%$ добычи открытым способом в регионе. Предприятия компании расположены в различных геологических районах и функционируют на протяжении более 30 лет. 
За последние 15 лет глубина открытых работ в филиалах ОАО «УК «Кузбассразрезуголь» увеличилась в среднем на 40 м и достигла 227 м при максимальной глубине 280 м на «Бачатском угольном разрезе». При этом, естественно возросли крепость вмещающих пород, дальность транспортирования, что потребовало от компании осуществления ускоренного технического переоснащения парка выемочно-погрузочной и горнотранспортной техники с увеличением емкости ковша экскаватора и вместимости кузова самосвала. В филиалы ОАО «УК «Кузбассразрезуголь» были приобретены экскаваторы: ЭКГ-18, ЭКГ-18Р, ЭКГ-32, PH-2800, PH-4100, WK-35, Komatsu PC-5500, Hitachi EX-3600, Terex RH-170, Terex RH-200, R-9350, в результате средняя емкость ковша выросла на треть с 9,6 куб. м в 2000 г. до 13,2 куб. м в 2015 г., что позволило за аналогичный период увеличить среднюю годовую производительность экскаватора с 1908,4 тыс. куб. м до 2 418,7 тыс. куб. м. Это обеспечило рост объема вскрышных работ с 194768 тыс. куб. м в 2000 г. до 331861 тыс. куб. м в 2015 г., т.е. на 70,3\%.

Рост количественных показателей является характерной чертой изменений и для других разрезов Кузнецкого бассейна. На сегодня ежегодный совокупный объем породы, которая обуривается, взрывается, экскавируется, транспортируется и складируется на разрезах в Кузбассе, превысил 1,3 млрд куб. м.

\section{ОБСУЖДЕНИЕ}

Как было отмечено выше, рост объема вскрышных и добычных работ стал возможен благодаря техническому перевооружению, в то же время, увеличение единичной мощности выемочно-погрузочного оборудования потребовало создания условий для эффективного использования новой техники, особенно гидравлических экскаваторов. В табл. 1 приведены данные об объеме работы, выполненной таким оборудованием на разрезах компании.

Согласно приведенным выше значениям гидравлические экскаваторы стали играть более заметную роль в технологии горного производства компании. В начале анализируемого периода гидравлические экскаваторы не применялись. В 2005 г. выемочно-погрузочное оборудование такого типа находилось на стадии опытного использования и ознакомления, было выполнено менее $3 \%$ вскрышных и порядка 13\% добычных работ. В 2010 г. достигнут пик объемов работ, выполненных гидравлическими экскаваторами: 18,1\% вскрыши и 38,5\% добычи. Стоит отметить, что опыт, накопленный производственниками за последние годы, показал высокую чувствительность гидравлических экскаваторов к качеству взрывного дробления горной массы. Так, исследования О.И. Литвина [1] показали, что гидравлические экскаваторы требуют увеличения удельного расхода взрывчатых веществ (BВ) на 4-15\% по сравнению с базовыми моделями прямых механических лопат со сравнимой вместимостью ковша.

Для обеспечения высокой производительности выемочно-погрузочного оборудования, особенно большой единичной мощности, требуется уменьшение длительности простоев при ведении взрывных работ посредством оптимизации объема резерва взорванной горной массы (ВГМ).
В работе К. А. Голубина [2], выполненной в 2013 г. для условий ОАО «УК «Кузбассразрезуголь», рассмотрены технологические аспекты управления резервом ВГМ, предложен алгоритм минимизации издержек по процессам, сопряженным с взрыванием, описаны известные зависимости между производительностью экскаватора и рациональной величиной резерва ВГМ, получены рекомендации по оптимизации резерва ВГМ для технологического оборудования, работающего в зоне взаимного влияния. Результаты проведенных исследований свидетельствуют о том, что оптимальная величина резерва ВГМ для экскаваторов большой единичной мощности требует интенсификации буровзрывных работ.

Анализ изменений, произошедших на разрезах Кузбасса за последние 15 лет, позволяет сделать следующие выводы:

- объем отрабатываемой горной массы в Кузбассе вырос и превысил 1,3 млрд куб. м, что определяет необходимость развития технологий, обеспечивающих снижение негативного воздействия открытых горных работ на окружающую среду;

- в результате технического переоснащения парка выемочно-погрузочной и горнотранспортной техники на разрезах компании «Кузбассразрезуголь» значительно выросла единичная мощность оборудования, появилось большое число гидравлических экскаваторов;

- гидравлические экскаваторы требуют более высокого качества взрывного дробления вскрышных пород, которое предопределяет необходимость увеличения удельного расхода ВВ на 4-15\% по сравнению с базовыми моделями прямых механических лопат со сравнимой вместимостью ковша;

- для подготовки резерва ВГМ для экскаваторов большой единичной мощности необходимо интенсифицировать ведение буровзрывных работ;

- среднее расстояние от участков ведения горных работ до населенных пунктов сокращается, что требует больше внимания к ведению буровзрывных работ в части снижения негативного воздействия на охраняемые здания и сооружения, а также окружающую природную среду.

Для преодоления негативных тенденций роста затрат на ведение горных работ и увеличения отрицательного воздействия на экосистему и жителей региона угольной компанией «Кузбассразрезуголь» была разработана Программа испытания и внедрения комплекса организационно-технических решений, обеспечивающих:

- возможность эффективно подготавливать горную массу буровзрывным способом для оборудования большой единичной мощности в требуемом объеме без превышения допустимых величин негативного воздействия взрыва;

Таблича 1

Объем работы, выполненной гидравлическими экскаваторами

\begin{tabular}{|c|c|c|c|c|}
\multirow{2}{*}{ Годы } & \multicolumn{2}{|c|}{$\begin{array}{c}\text { Выполнено вскрышных работ, } \\
\text { тыс.куб. м }\end{array}$} & \multicolumn{2}{|c|}{ Добыто угля, тыс. т } \\
\cline { 2 - 5 } & Всего & $\begin{array}{c}\text { Гидравлическими } \\
\text { экскаваторами }\end{array}$ & Всего & $\begin{array}{c}\text { Гидравлическими } \\
\text { экскаваторами }\end{array}$ \\
\hline 2000 & 194768 & - & 34557 & - \\
\hline 2005 & 269432 & 6400 & 42838 & 5500 \\
\hline 2010 & 334769 & 60900 & 49708 & 19150 \\
\hline 2015 & 331861 & 49900 & 44325 & 17900 \\
\hline
\end{tabular}


- рациональное качество взрывного дробления горной массы с одновременным снижением удельного расхода взрывчатых веществ.

Одно из основных направлений совершенствования буровзрывных работ, принятых этой программой, основывается на результатах исследований, выполненных ранее в ИГД им. А. А. Скочинского под научным руководством академика Н.В. Мельникова и доктора техн. наук Л.Н. Марченко, которыми установлено, что одним из путей значительного повышения КПД взрыва является изменение механизма передачи энергии взрыва в твердой среде за счет рационального перераспределения ее во времени и пространстве [3, 4]. На основании этой концепции разработаны новые методы и средства взрывания [5], в основу которых положено изменение конструкции скважинных зарядов путем рассредоточения заряда в скважине, а также совершенствования конструкции скважинной забойки.

Решению этих задач посвящены исследования сотрудников ООО «Кузбассразрезуголь-Взрывпром», занимающегося ведением взрывных работ на разрезах компании, С.В. Кокина [6] и С.В. Гришина [7], а также сотрудников научно-внедренческой организации ООО «Строймаш» С.М. Федотенко и В.С. Федотенко [8]. Их научные разработки послужили основой практической реализации в Кузбассе идеи управления качеством взрыва за счет совершенствования конструкции заряда. В основу работы положены данные, полученные экспериментальным путем в результате проверки в промышленных условиях эффективности применения устройств для рассредоточения заряда ВВ в скважине и универсальных запирающих устройств (далее УЗУ) для забойки скважин, защищенных патентами РФ на изобретения [9-13].

Широкому внедрению этих решений в практику буровзрывных работ на разрезах компании предшествовал анализ технической документации на пневматические и подвесные скважинные затворы, выполненный экспертами Новационной фирмы «КУЗБАСС-НИИОГР» [14], затем на основании разрешения Ростехнадзора были проведены в 2010-2011 гг. совместные испытания их в промышленных условиях. В результате было получено положительное заключение экспертизы промышленной безопасности о безопасном применении указанных устройств [15]. В заключении отмечено, что применение пневматических и подвесных скважинных затворов позволяет:

- снизить удельный расход ВВ при сохранении качества подготовленной горной массы к выемке, без снижения производительности выемочно-погрузочного оборудования;

- значительно снизить себестоимость ведения взрывных работ за счет снижения количества используемых водоустойчивых взрывчатых веществ путем отсечения столба воды от верхней части заряда с неводоустойчивым BB.

Эксперты отметили также, что конструкции пневматических и подвесных скважинных затворов обеспечивают:

- значительное упрощение процесса формирования рассредоточенных зарядов ВВ в скважине, при этом способ их установки гарантирует точность размещения затворов на необходимой глубине, что обеспечивает создание проектной конструкции заряда с воздушными или иными промежутками любой необходимой величины;
— надежность удержания верхней часть заряда ВВ в течение времени, достаточного для зарядки и взрывания блока;

— техническую возможность осуществить рассредоточение заряда ВВ в скважинах путем создания водного, водновоздушного и воздушного промежутков за счет их установки не только в сухих, но и в обводненных скважинах.

Эксперты Новационной фирмы «КУЗБАСС-НИИОГР» положительно оценили перспективу применения на разрезах Кузбасса универсальных запирающих устройств. Вначале было выдано положительное заключение экспертизы промышленной безопасности на техническую документацию на универсальные запирающие устройства [16], а по результатам их испытаний в промышленных условиях положительное заключение о безопасности применения таких устройств [17].

Опираясь на экспертные оценки безопасности использования технических устройств по рассредоточению скважинных зарядов и забойки скважинных зарядов, ОАО «УК «Кузбассразрезуголь» было принято решение провести обширные промышленные испытания на разрезах компании с целью выявить возможность и оценить целесообразность включения в производственный цикл испытываемые организационно-технические решения для снижения негативного воздействия взрывных работ на окружающую среду, повышения качества дробления горной массы, а также снижения себестоимости ведения горных работ.

Всего в реализацию программ экспериментов были вовлечены разрезы всех шести филиалов ОАО «УК «Кузбассразрезуголь». За период с конца 2012 г. до середины 2015 г. было проведено более 600 экспериментальных взрывов. В качестве объектов исследования были выбраны:

- способы и устройства для забойки скважин;

- способы рассредоточения заряда ВВ основанные на создании:

- осевых полостей в скважинах;

— поперечных полостей в скважинах;

- способы снижения интенсивности пылеобразования.

Стоит отметить, что в результате проводимой работы в качестве отдельного направления исследований стало рассматриваться создание промежутка в донной части скважины из-за наличия ряда особенностей в конструкции, а также в получаемом эффекте.

Результаты проведенных экспериментов принимались и актировались комиссией, состоящей из представителей головного аппарата ОАО «УК «Кузбассразрезуголь», филиала ООО «Кузбассразрезуголь-Взрывпром», проводящего эксперимент, и организации, осуществляющей авторский надзор.

\section{СКВАЖИННАЯ ЗАБОЙКА}

Конструкция и схема установки универсальных запирающих устройств в скважину изображены на рис. 1.

В рамках исследования способов и устройств для забойки скважин было проведено 429 экспериментальных опытно-промышленных взрывов, в ходе которых испытывались универсальные запирающие устройства (УЗУ) и их модификации. Испытания проводились в филиалах: Краснобродский, Талдинский, Бачатский, Кедровский, Кал- 
a

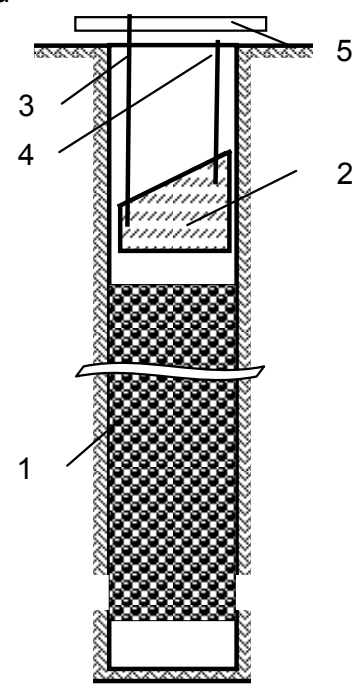

6

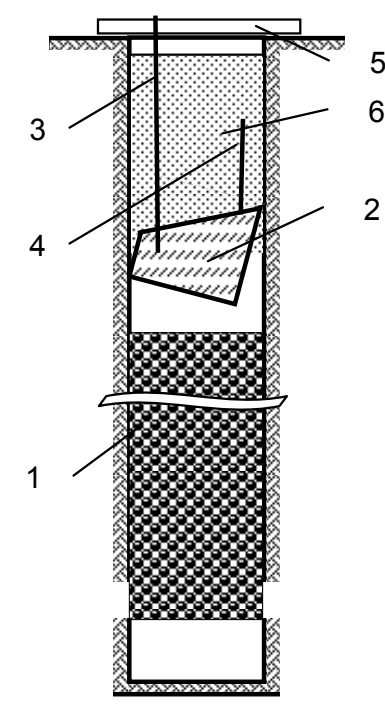

Рис. 1. Конструкция и схема установки узу:

а- формирование заряда взрывчатого вещества (BВ) и опускание УзУ в скважину; б - установка УзУ в скважине;

1 - заряд ВВ; 2 - чилиндр Узу; 3, 4- шпагат;

5 - поперечная перекладина; 6 - буровая мелочь

танский и Моховский. Это позволило испытать устройства в самых различных горно-геологических и производственных условиях. Все экспериментальные блоки отработаны, недочетов по качеству подготовки не выявлено, производительность выемочно-погрузочного оборудования соответствует запланированной.

По результатам проведенных экспериментальных взрывов построена зависимость, отражающая относительное снижение объема используемого ВB $\Delta q / q$ от коэффициента крепости взрываемых пород $f$ при выполнении скважинной забойки с применением УзУ (рис. 2), где: $\Delta q-$ разность между базовым и фактическим удельным расходом ВB; $q$ - базовый удельный расход ВВ.

Исследуемая зависимость представлена выпуклой кривой, монотонно возрастающей во всем диапазоне исследуемых значений. Согласно полученной зависимости относительное снижение объема используемого ВВ, при использовании УЗУ для выполнения скважинной забойки, изменяется в интервале от 9,5 до 12,3\%.

Стоит отметить, что по результатам всехэкспериментальных взрывов качество взрывной подготовки на экспери-

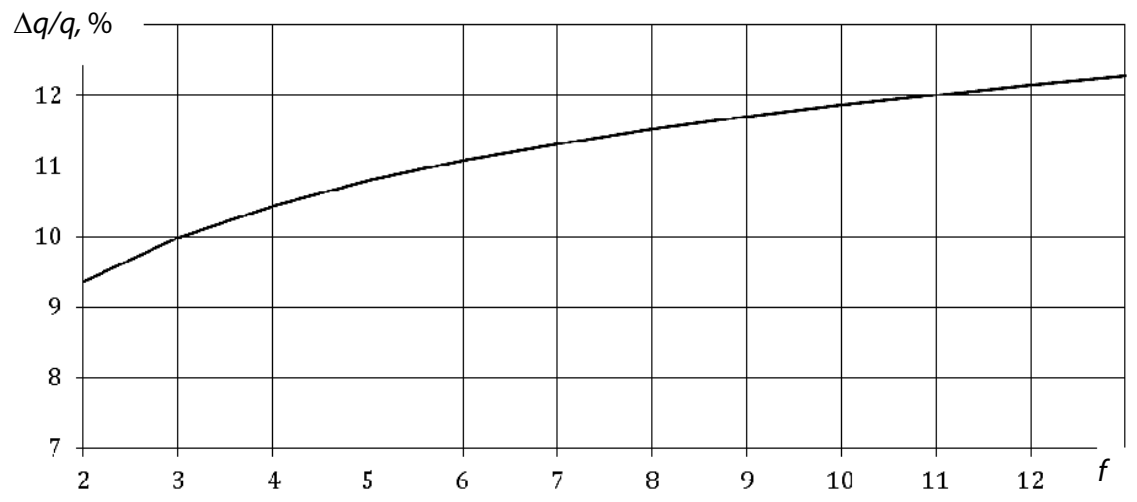

Puс. 2. Зависимость относительного снижения объема используемого ВВ от крепости взрываемых пород при применении Узу

ментальном участке блока соответствует рациональному. При обработке результатов было учтено, что при расчете параметров БВР крепость пород округляется до целого значения и может равновероятно колебаться в интервале \pm 1 от указанного в паспорте БВР значения.

Кроме того, снижение удельного расхода ВВ создает условия для уменьшения объемов бурения, что является значимым техническим и, соответственно, экономическим результатом.

Порядка $80 \%$ исходных данных получено для значения коэффициента крепости от 5 до 10 по шкале проф. М.М. Протодьяконова, что позволяет говорить о высокой степени достоверности результатов в данном диапазоне. Это является важным при учете того, что более $70 \%$ взрывных работ на разрезах ОАО «УК «Кузбассразрезуголь» ведется по породам с коэффициентом крепости от 5 до 10.

Таким образом можно сделать вывод, что при применении УзУ для забойки скважин при взрывании пород с коэффициентом крепости от 2 до 13 относительное снижение объема используемого ВВ прямо пропорционально крепости взрываемых пород и находится в диапазоне от 9,5 до 12,3\%.

На рис. 3 приведена зависимость величины абсолютного снижения объема используемого ВВ $\Delta q$ от крепости пород при взрывании для экскаваторов с емкостью ковша от 32 до 35 куб. м.

При построении были использованы данные, полученные в результате проведения буровзрывной подготовки пород для выемки экскаваторами ЭКГ-32Р ( $E=32$ куб. м), PH-2800 ( $E=33$ куб. м), WK-35 ( $E=35$ куб. м). При этом для перечисленных экскаваторов имеются актированные данные только для диапазона пород с коэффициентом крепости от 5 до 10 по шкале проф. М.М. Протодьяконова. Значения для интервалов крепости (2-5) и (10-13) были получены при помощи экстраполяции с учетом зависимости, полученной ранее и приведенной на рис. 2.

Зависимость, изображенная на рис. 3, является вогнутой и возрастает монотонно во всем диапазоне рассматриваемых значений независимого параметра $f$. Абсолютная величина экономии ВВ на 1 млн куб. м горной породы, взорванной для экскаваторов с емкостью ковша 32-35 куб. м, приведенная в табл. 2, была получена следующим образом.

Пользуясь зависимостью величины абсолютного снижения объема используемого ВВ от крепости взрываемых пород, представленной на рис. 2, была определена величина экономии ВВ в граммах. Так, например, при коэффициенте крепости взрываемой породы 9 величина экономии на 1 куб. м составляет 75,9 г. Тогда на 1 млн куб. м она составит 75,9 т. При средней цене ВВ в 2015 г. 16000 руб. экономия для рассмотренного варианта составит 1214,4 тыс. руб.

Как было упомянуто ранее, негативное воздействие буровзрывных работ на окружающую среду заключается в сейсмическом, ударно-волновом, а также токсическом воздействии.

Для контроля уровня сейсмического воздействия взрывов использовался сейсмографический комплекс 
Величина экономии ВВ при буровзрывной подготовке пород различной крепости в объеме 1 млн куб. м экскаваторами с вместимостью ковша 32-35 куб. м

\begin{tabular}{|l|c|c|c|c|}
\multicolumn{1}{c|}{ Показатели } & \multicolumn{4}{|c|}{ Крепость пород, $\boldsymbol{f}$} \\
\cline { 2 - 5 } & $\mathbf{3}$ & $\mathbf{6}$ & $\mathbf{9}$ & $\mathbf{1 2}$ \\
\hline Экономия ВВ, т & 19,8 & 40,7 & 75,9 & 122,1 \\
\hline Экономия при средней цене 1 т ВВ 16000 руб. & 316800 & 651200 & 1214400 & 1953600
\end{tabular}

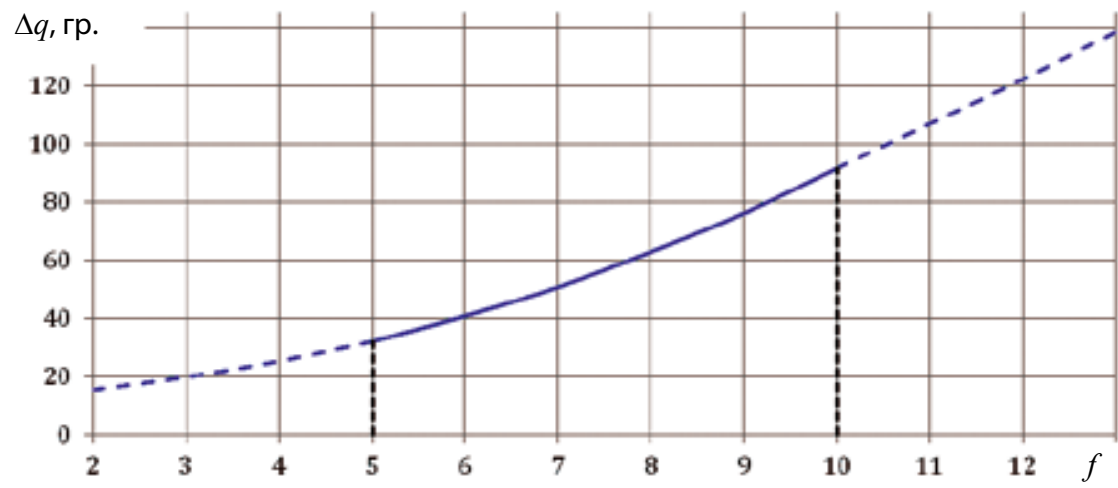

Puс. 3. Зависимость величины абсолютного снижения объема используемого ВВ от крепости взрываемых пород при взрывании для экскаваторов с емкостью ковиа от 32 до $35 \mathrm{M}^{3}$

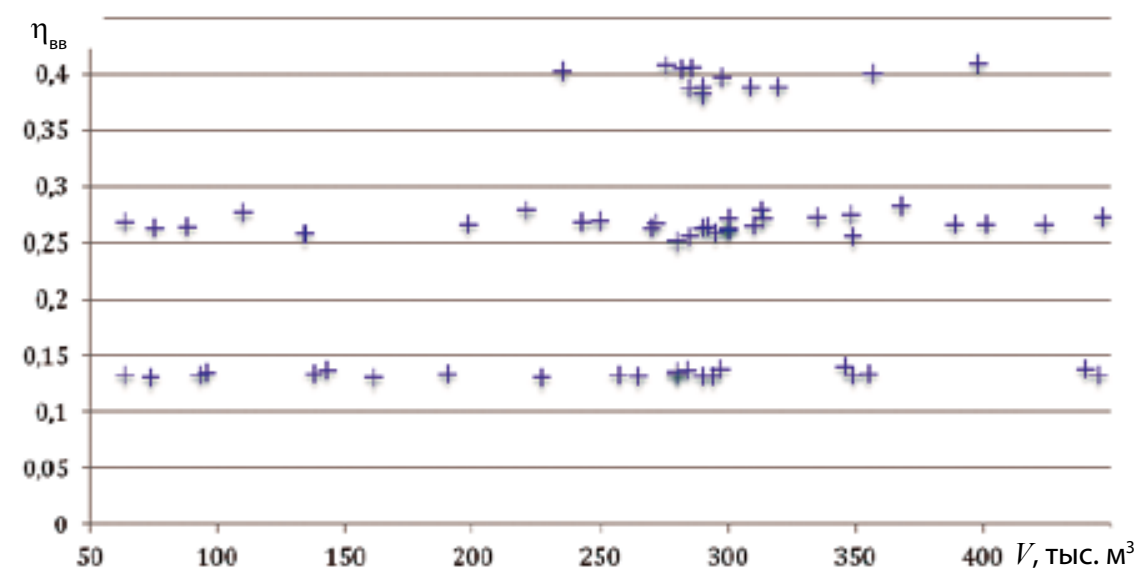

Puс. 4. Зависимость уровня выбросов взвешенных веществ от объема взорванного блока для филиала Кедровский при использовании УзУ

INSTANTEL. Датчики располагались рядом с объектами жилой и социальной инфраструктуры (больницы, школы, жилые дома). В ходе экспериментов скорости смещения на расстоянии от 3 до 7 км от взрываемого блока до охраняемых объектов находились в пределах значений, приведенных в справочном приложении Б ГОСТ Р 52892 2007 «Вибрация и удар. Вибрация зданий».

Для оценки возможности использования УзУ для снижения негативного воздействия на окружающую природную среду санпрофлабораторией филиала «Кедровский угольный разрез» были измерены выбросы взвешенных веществ в границах санитарно-защитных зон (далее C33). Полученные результаты приведены на рис. 4.

Из графика на рис. 4 следует, что функциональная связь между объемом взорванной горной массы и уровнем выбросов взвешенных веществ отсутствует. При этом прeвышений предельно допустимых величин выбросов на границах СЗ3 зафиксировано не было.

Результаты проведенной работы свидетельствуют о возможности за счет применения разработанных конструкций скважинных зарядов управлять запасами взорванной гор- ной массы в целях оптимизации работы выемочно-погрузочного и горнотранспортного оборудования при обеспечении требуемого качества взрывного дробления, а также для снижения негативного воздействия взрывных работ на окружающую среду и охраняемые объекты в границах санитарно-защитной зоны. Это особенно актуально в связи с модернизацией парка выемочно-погрузочного и горнотранспортного оборудования на угольных предприятиях ОАО «УК «Кузбассразрезуголь».

Таким образом, опираясь на проведенные исследования можно сделать вывод, что применение УзУ позволяет снизить негативное воздействие взрыва на окружающую среду и одновременно увеличить объем горной массы, который возможно одновременно подготовить к выемке буровзрывным способом, не нарушая действующих нормативных требований в области безопасности ведения горных работ и охраны окружающей среды.

Для оценки трудозатрат на ведение буровзрывных работ на участках горных работ ОАО «УК «Кузбассразрезуголь» был проведен хронометражвыполнения скважинной забойки сприменением УЗУ, а также для сравнения, сплошной забойки буровым штыбом. Обработанные результаты представлены на рис. 5.

На рис. 5 изображена зависимость изменения величины экономии времени на забойку одной скважины с применением испытываемых устройств вместо сплошной забойки буровой мелочью от количества скважинных забоек, выполненных одним работником за смену. Из графика на рис. 5 видно, что с увеличением количества скважинных забоек, выполненных одним работником за смену, экономия времени возрастает. Это объясняется накапливающейся усталостью при выполнении тяжелой физической работы. В абсолютном выражении на каждую 1000 забоек, выполненных при помощи УЗУ, экономия труда составляет порядка 50 чел.-ч.

С учетом вышеизложенного можно сделать вывод, что экономия времени на выполнение скважинной забойки с применением УзУ прямо пропорциональна количеству забоек, выполненных одним работником за смену, и изменяется от 1,2 до 3 мин. на одну скважину.

Опираясь на анализ выполненных исследований можно сделать вывод, что применение УЗУ при ведении буровзрывных работ в филиалах ОАО «УК «Кузбассразре- 
зуголь» позволяет получить комплексный эффект, заключающийся в:

— экономии ВВ на 9,5-12,3\%;

- кратном увеличении объема породы, который возможно одновременно подготавливать к выемке буровзрывным способом;

- снижении влияния массовых взрывов на уровень вредных выбросов на границах санитарно-защитных зон;

- экономии затрат труда от 1,2 до 3 чел. -мин. на выполнение одной скважинной забойки.

\section{РАССРЕДОТОЧЕНИЕ ЗАРЯДА В СКВАЖИНЕ}

В рамках испытаний при ведении буровзрывных работ были испытаны устройства для формирования рассредоточенного заряда. В данном направлении с 2012 по 2015 гг. было проведено 64 опытных взрыва. Это отвечает требованию о необходимом и достаточном количестве испытаний, поэтому результаты обработки полученных данных могут быть признаны достоверными.

На рис. 6 изображено изменение относительного снижения используемого ВВ при рассредоточении заряда, в скважине в зависимости от высоты взрываемого уступа.

Из графика на рис. 6 видно, что рассредоточение заряда позволяет снизить удельный расход ВВ на величину от 12,3 до 15,8\%. При этом с увеличением высоты уступа доля ВB, на которую снижают столб заряда ожидаемо растет. Также стоит отметить, что в ходе испытаний было подтверждено предположение о том, что рассредоточение заряда в скважине снижает интенсивность пылеобразования при

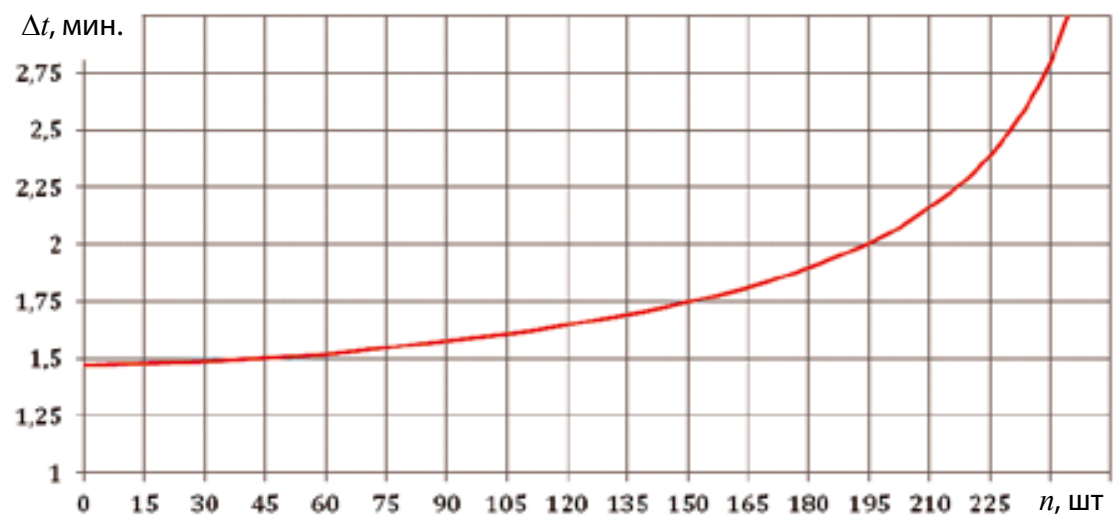

Рис. 5. Экономия времени на забойку одной скважины с применением УзУ вместо сплошной забойки буровой мелочью в зависимости от количества скважинных забоек, выполненных одним работником за смену

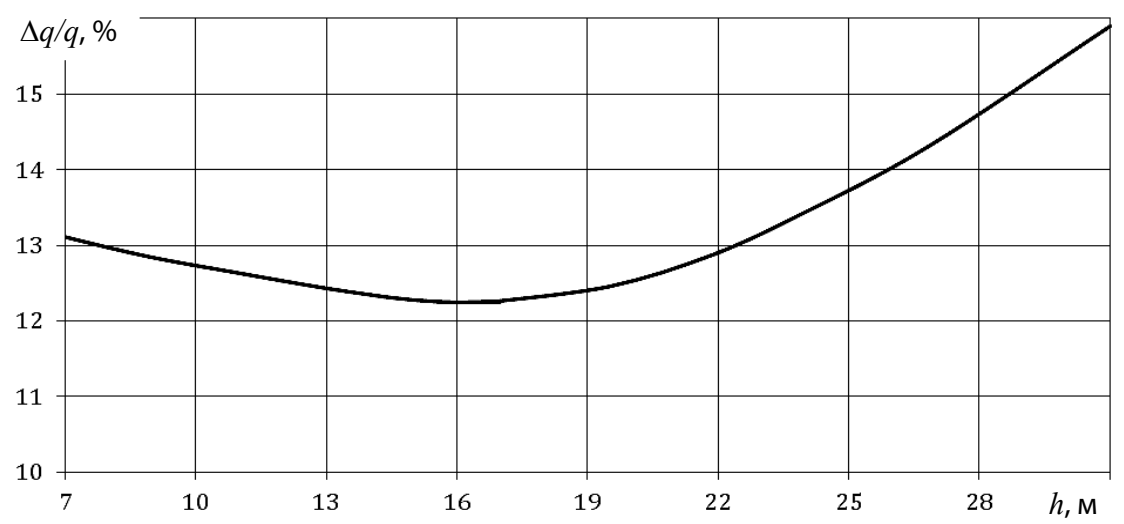

Рис. 6. Зависимость относительного снижения объема используемого ВВ при рассредоточении заряда в скважине от высоты взрываемого уступа ведении взрывных работ за счет уменьшения переизмельчения породы в ближней зоне заряда.

Заряд в скважинах был рассредоточен при помощи пневматических и подвесных затворов, а также специальных полипропиленовых рукавов, конструкции которых защищены патентами РФ.

По проведенным экспериментам можно сделать следующий вывод: установлено, что рассредоточение зарядов в скважинах уменьиает негативное воздействие взрыва на окружающую среду и позволяет снизить удельный расход ВВ на величину до 15,8\%, при этом эффект увеличивается с ростом высоты взрываемого ycmyna.

Значимым результатом проведенных эмпирических исследований стало установление возможности эффективно снижать интенсивность пылеобразования при ведении взрывных работ за счет формирования рассредоточенного заряда. Описываемый эффект достигается за счет уменьшения переизмельчения взрываемой породы в ближней зоне заряда. Это подтверждает выводы ранее проведенных исследований [3, 4], что рассредоточение заряда в скважине позволяет более эффективно передавать энергию взрываемому массиву.

Отдельного упоминания заслуживает то, что в 2015 г. начата работа по апробации способов рассредоточения эмульсионных взрывчатых веществ в обводненных скважинах. В конце первого полугодия 2015 г. получен ряд разнородных результатов, предварительно свидетельствующих о перспективности выбранного направления. Недостаточный объем проведенных исследований не позволяет сделать достоверных выводов.

\section{СОЗДАНИЕ ПРОМЕЖУТКА}

\section{В ДОННОЙ ЧАСТИ СКВАЖИНЫ}

В ходе реализации программы опытно-промышленных экспериментов были испытаны также устройства рассредоточения заряда в донной части скважины. Данные устройства испытывались на 109 массовых взрывах, что отвечает условию достаточности, сформулированному в разделе 6 «Сроки и объем проведения испытаний» программы экспериментов. На экспериментальной части взрывных блоков были установлены устройства, формирующие промежуток в донной части заряда на величину перебура длиной от 1 до 1,5 м в скважинах диаметром 215,9 и 270 мм.

Согласно полученным результатам качество буровзрывной подготовки на экспериментальной части взорванных блоков идентично качеству на контрольной части и соответствует рациональному. При этом фактическая экономия заряда составила от 45 до 50 кг для скважин диаметром 215,9 мм и от 75 до 85 кг для скважин диаметром 270 мм. Таким образом, в денежном выражении при настоящем уровне цен экономия составля- 
em om 720 до 1360 руб. на 1 скважину. Так, например, 28 августа 2014 г. в филиале ОАО «УК «Кузбассразрезуголь» «Краснобродский угольный разрез» (Краснобродское поле) на участке ведения горных работ №3, блок №181 произведена подготовка горной породы к выемке буровзрывным способом для последующей отработки экскаватором ЭШ 11/70 № 53. Взорванные породы представлены песчаником с коэффициентом крепости 9 по шкале проф. М.М. Протодьяконова, диаметр пробуренных скважин 215,9 мм с сеткой $6 \times 6$ м. Экспериментальная часть блока была заряжена с применением 50 шт. придонных компенсаторов длиной 1,25 м, объем экспериментальной части составил 14400 куб. м. Контрольная часть была заряжена сплошным зарядом. Качество взрывного дробления, а также производительность экскаватора соответствуют требуемым. Применение описываемого организационнотехнического решения позволило сэкономить 36 тыс. руб.

\section{ЗАКЛЮЧЕНИЕ}

В ходе работы, проведенной за период с 2011 по 2015 г., был разработан, испытан и внедрен в филиалах ОАО «УК «Кузбассразрезуголь» комплекс организационнотехнических решений по рассредоточению скважинных зарядов и обеспечению качественной забойки скважинных зарядов с использованием УзУ, применение которых обеспечивает:

— возможность эффективно подготавливать горную массу буровзрывным способом для оборудования большой единичной мощности в требуемом объеме без превышения допустимых величин негативного воздействия;

- рациональное качество взрывного дробления горной массы с одновременным снижением удельного расхода взрывчатых веществ.

Положительные результаты, продемонстрированные уже на начальных этапах работы, позволили перейти к внедрению разработок. С 2013 по 2015 г. благодаря использованию универсальных запирающих устройств (УЗУ), скважинных затворов и придонных компенсаторов ОАО «УК «Кузбассразрезуголь» удалось добиться фактического снижения массы применяемых взрывчатых веществ относительно базового на 62,8 тыс. т, что в стоимостном выражении составляет порядка 1 млрд руб.

Не менее значимым эффектом, полученным в результате внедрения испытанныхорганизационно-техническихрешений, является снижение объема и интенсивности негативного воздействия на окружающую среду. Экономия 62,8тыс. т ВВ на фоне роста объемов отрабатываемой горной массы является ощутимым вкладом в сбережение природных ресурсов и сохранение здоровья кузбассовцев.

\section{Список литературы}

1. Литвин О.И. Обоснование рациональных технологических параметров производства вскрышных работ обратными гидравлическими лопатами на разрезах Кузбасса. Автореф. диссерт. канд. техн. наук. Кемерово, 2012.

2. Голубин К. А. Обоснование резерва взорванной горной массы на разрезах с автомобильным транспортом. Автореф. диссерт. канд. техн. наук. Кемерово, 2013.

3. Мельников Н.В. Влияние конструкции заряда на результаты взрывных работ. В кн.: Разрушение и механика горных пород. М.: Госгортехиздат, 1962.
4. Мельников Н. В., Марченко И. А., Жариков И.Ф., Сеинов Н.П. Метод улучшения дробления пород взрывом // Физико-технические проблемы разработки полезных ископаемых. 1979. №6. С. 32-34.

5. Оптимизация взрывных работ на разрезах угольной компании «Кузбассразрезуголь» / Е. И. Сапрыкин, С. М. Федотенко, С.В.Гришин и др. // Горный журнал. 2006. №11. С. 65-67.

6. Кокин С. В. Разработка и обоснование технических и технологических решений при взрывной подготовке обводненныхвскрышныхпород кэкскавации на разрезахКузбасса. Автореф. диссерт. канд. техн. наук. Кемерово, 2011.

7. Гришин С. В. Обоснование предварительного контурного взрывания при подготовке обводненных вскрышных уступов на разрезах Кузбасса. Автореф. диссерт. канд. техн. наук. Кемерово, 2010.

8. Федотенко В.С. Обоснование проектных решений по производству вскрышных работ высокими уступами на разрезах Кузбасса Автореф. диссерт. канд. техн. наук. М., 2012.

9. Пат. 2235971 Российская Федерация, МПК6 F 42 D 1/08, F 42 D 1/02. Способ рассредоточения заряда в скважине / Федотенко С. М.; заявитель и патентообладатель Федотенко С. М. №2003123657/03; заявл. 25.07.03; опубл. 10.09.2004, Бюл. №25. 4 с.: ил. 2.

10. Пат. 2319924 Российская Федерация, МПК6 F 42 D 1/08. Способ рассредоточения заряда в скважине / Федотенко С. М., Федотенко В.С.; заявитель и патентообладатель Федотенко С. М., Федотенко В.С. №2006124019/03; заявл. 04.07.06; опубл. 20.03.2008, Бюл. №8. 4 с.: ил. 3.

11. Пат. 2371671 Российская Федерация, МПК6 F 42 D 1/08. Подвесная скважинная забойка / Федотенко С. М., Федотенко В.С. Федотенко Н. А.; заявитель и патентообладатель Федотенко С. М., Федотенко В.С., Федотенко Н. А. №2008115168/03; заявл. 17.04.08; опубл. 27.10.2009, Бюл. №30. 5 с.: ил. 2.

12. Пат. 2379621 Российская Федерация, МПК6 F 42 D 1/08. Способ рассредоточения заряда в скважине / Федотенко С. М., Федотенко В.С. Федотенко Н. А.; заявитель и патентообладатель Федотенко С.М., Федотенко В.С., Федотенко Н. А. №2008131212/03; заявл. 28.07.08; опубл. 20.01.2010, Бюл. №2. 5 с.: ил. 2.

13. Пат. 2401416 Российская Федерация, МПК6 F 42 D 1/08. Подвесная скважинная забойка / Федотенко С. М., Федотенко В.С. Федотенко Н. А.; заявитель и патентообладатель Федотенко С. М., Федотенко В. С., Федотенко Н. А. №2009128388/03; заявл. 22.07.09; опубл. 10.10.2010, Бюл. №28. 5 с.: ил. 2.

14. Заключение экспертизы промышленной безопасности №129-2010 (рег. №68-ТУ-29478-2010 от 24.12.2010 г.) на техническую документацию на пневматические скважинные затворы типа ПСЗ 140, ПСЗ 170, ПСЗ 200, ПСЗ 216, ПСЗ 245, ПС3 270 и подвесные скважинные затворы типа ПдС3 140, ПдС3 170, ПдС3 200, ПдС3 216, ПдС3 245, ПдС3 270. Кемерово, 2010.

15. Заключение экспертизы промышленной безопасности №100-2011 (рег. №68-ИД-38149-2011 от 29.11.2011 г.) на пневматические скважинные затворы типа ПСЗ 140, ПСЗ 170, ПСЗ 200, ПСЗ 216, ПСЗ 245, ПС3 270 и подвесные скважинные затворы типа ПдС3 140, ПдС3 170, ПдС3 200, ПдС3 216, ПдС3 245, ПдС3 270. Кемерово, 2011. 
16. Заключение экспертизы промышленной безопасности №78-2010 (рег. № 07-03-ТУ-03389-2010 от 02.08.2010 г.) на техническую документацию на универсальные запирающие устройства типа УЗУ-140, УЗУ-170, УЗУ-200, УЗУ-216, узУ-245, УзУ-270. Кемерово, 2010.
17. Заключение экспертизы промышленной безопасности №51-2011 (рег. №68-ИД-39428-2011 от 23.06.2011) на универсальные запирающиеся устройства типа УзУ140, УзУ-170, УзУ-200, УзУ-216, УзУ-245, УзУ-270. Кемерово, 2011.

UDC 622.271:622.233: :622.235(571.17) ๔ S.V. Matva, S.V. Kokin, Yu.I. Litvin, S.I. Protasov, G.N. Kornev, V.S. Fedotenko, 2015

SURFACE MINING

ISSN 0041-5790 (Print) • ISSN 2412-8333 (Online) • Ugol' — Russian Coal Journal, 2015, № 12, pp. 24-31

Title

IMPROVEMENT OF BLAST-HOLE DRILLING METHODS FOR ROCK MASS PREPARATION

AT THE ENTERPRISES OF “UK KUZBASSRAZREZUGOL” OJSC

DOI: http://dx.doi.org/10.18796/0041-5790-2015-12-24-31

Authors

Matva S.V. ${ }^{1}$, Kokin S.V. ${ }^{2}$, Litvin Yu.I. ${ }^{1}$, Protasov S.I. ${ }^{3}$, Kornev G.N. ${ }^{1}$, Fedotenko V.S. ${ }^{4}$

1 "UK Kuzbassrazrezugol” OJSC, Kemerovo, 650054, Russian Federation

2 "Kuzbassrazrezugol-Vzryvprom" LLC, Kemerovo, 650054, Russian Federation

3 "Kuzbass-NIIOGR, Novatsionnaya firma" LLC, Kemerovo, 650054, Russian Federation

4 "Stroymash" LLC, Kemerovo, 650036, Russian Federation

\section{Authors' Information}

Matva S.V., Deputy Director — Engineering Director, e-mail: matva@kru.ru Kokin S.V., PhD (Engineering), General Director, e-mail: kokinsv@kruvp.kru.ru Litvin Yu.l., Head of mining operations planning department,

e-mail: litvinui@kru.ru

Protasov S.I., PhD (Engineering), General Director,

e-mail: protasov@kuzbass-niiogr.ru

Kornev G.N., Head of blast-hole drilling operations department,

e-mail: kornev@kru.ru

Fedotenko V.S., PhD (Engineering), Deputy General Director,

e-mail: victorfedotenko@gmail.com

\section{Abstract}

The changes at the Kuzbass coal strip mines during the recent 15 years were reviewed. The program of organizational and engineering solutions system testing and introduction was developed to allow the rock mass preparation by blasthole drilling method in the required volume without exceeding the permitted values of negative blast impact and ensuring the reasonable quality of rock mass blasting with simultaneous reduction of specific consumption of blasting materials. In total, more than 600 experimental blasts were carried out. The methods of well stemming, charges distribution in the hole and methods of air gaps creation in the bottom part of hole were tested. The introduction of tested methods at the branches of "UK Kuzbassrazrezugol" OJSC provided the saving of 62.8 thou. $t$ of explosives and minimization of negative environmental impact between 2013 and 2015.

\section{Keywords}

Open-cast mining works, blasthole drilling works, charge design, blast en ergy, hole tamping, distribution, air gap, overdrilling, environment, equipment capacity

\section{References}

1. Litvin O.I. Obosnovanie rationalnykh tekhnologicheskih parametrov proizvodstvadsrryshnykh rabot obratnymi hydravlicheskimi lopatami na razrezakh Kuzbassa [Validation of rational technological parameters of overburden removal with hydraulic backhoes at the Kuzbass coal mines]. Avtoref. diss. kand. tekhn. nauk [Extended abstract of PhD (Engineering) Diss.]. Kemerovo, 2012.

2. Golubin K.A. Obosnovanie reserve vzorvannoy gornoy massy na razrezakl avtomobilnym transportom [Validation of blasted rock mass reserve at the coal mines with vehicle transportation of coal]. Avtoref. diss. kand. tekhn. nauk [Extended abstract of PhD (Engineering) Diss.]. Kemerovo, 2013.

3. Melnikov N.V. Vliyanie konstruktsii zaryada na rezultaty vzryvnykh rabot [Effect of charge design on the blasting result]. V kn.: Razrushenie i mekhanika gornykh porod [In: Destruction and mechanics of rocks]. Moscow, Gosgortechizdat Publ., 1962.

4. Melnikov N.V., Marchenko I.A., Zharikov I.F., Seinov N.P. Metod uluchsheniya drobleniya porod vzryvom [Improvement of rock breaking by blasting method]. Fiziko-tehnicheskie problemyi razrabotkipoleznyih iskopaemyih - Journa of Mining Science, 1979, no. 6, pp. 32-34.

5. Saprykin E.I., Fedotenko S.M., Grishin S.V. et al. Optimizatsiya vzryvnykh rabot na razrezakh ugolnoy kompanii "Kuzbassrazrezugol" [Blasting works optimization at the coal mines of "Kuzbassrazrezugol"Company]. Gorny Zhurnal - Mining Journal, 2006, no. 11, pp. 65-67.

6. Kokin S.V. Razrabotka i obosnovanie teknicheskikh I tekhnologicheskikh resheniy pri vzryvnoy podgotovke obvodnennylh vskryshnykh porod k ekska vatsii na razrezakh Kuzbassa [The development and validation of technical and technological solutions for the blasting preparation of water-saturated overburden rocks at the Kuzbass coal mines]. Avtoref. diss. kand. tekhn. nauk [Extended abstract of PhD (Engineering) Diss.]. Kemerovo, 2011.

7. Grishin S.V. Obosnovanie predvaritelnogo konturnogo vzryvaniya pri podgotovke obvodnennylh vskryshnykh ustupov na razrezakh Kuzbassa [Justification of preliminary perimeter blasting technique during the preparation of watersaturated overburden benches at the Kuzbass coal mines]. Avtoref. diss. kand tekhn. nauk [Extended abstract of PhD (Engineering) Diss.]. Kemerovo, 2010. 8. Fedotenko V.S. Obosnovanie proektnykh resheniy po proizvodstvu vskryshnykh rabot vysokimi ustupami na razrezakh Kuzbassa [Justification of design solutions for overburden operations with high benches at the Kuzbass coal mines]. Avtoref. diss. kand. tekhn. nauk [Extended abstract of PhD (Engineering) Diss.]. Moscow, 2012.

9. RF Patent no. 2235971, IPC 6 F 42 D 1/08, F 42 D 1/02. Sposob rassretotocheniya zaryada $v$ skvazhine [Method for charge distribution in a deep hole]. Applicant and patent holder — Fedotenko S.M., no. 2003123657/03, appl. 25.07.03, publ. 10.09.2004, Bull. no. 25, 4 pp., 2 Figs.

10. RF Patent no. 2319924, IPC 6 F 42 D 1/08. Sposob rassretotocheniya zaryada $v$ skvazhine [Method for charge distribution in a deep hole]. Applicant and patent holder — Fedotenko S.M., Fedotenko V.S., no. 2006124019/03, appl. 04.07.06, publ. 20.03.2008, Bull. no. 8, 4 pp., 3 Figs

11. RF Patent no. 2371671, IPC 6 F 42 D 1/08. Podvesnaya skvazhinaya zaboyka [Suspended well stem]. Applicant and patent holder — Fedotenko S.M., Fedotenko V.S., Fedotenko N.A., no. 2008115168/03, appl. 17.04.08, publ. 27.10.2009, Bull. no. 30, 5 pp., 2 Figs.

12. RF Patent no. 2379621, IPC 6 F 42 D 1/08. Sposob rassretotocheniya zaryada $v$ skvazhine [Method for charge distribution in a deep hole]. Applicant and patent holder - Fedotenko S.M., Fedotenko V.S., Fedotenko N.A., no. 2008131212/03, appl. 28.07.08, publ. 20.01.2010, Bull. no. 2, 5 pp., 2 Figs. 13. RF Patent no. 2401416, IPC 6 F 42 D 1/08. Podvesnaya skvazhinaya zaboy$k a$ [Suspended well stem]. Applicant and patent holder - Fedotenko S.M. Fedotenko V.S., Fedotenko N.A., no. 2009128388/03, appl. 22.07.09, publ. 10.10.2010, Bull. no. 28, 5 pp., 2 Figs.

14. Zaklyuchenie ekspertizy promyshlennoy bezopanosti no. 129-2010 (reg. no. 68-TU-29478-2010 ot 24.12.2010 g.) [Conclusion of industrial safety expertise no. $129-2010$ (reg. no. 68-TU-29478-2010 of 24.12.2010) to technical documentation for air-operated blast-hole plugs of types PSZ 140, PSZ 170, PSZ 200, PSZ 216, PSZ 245, PSZ 270 and suspended blast-hole plugs of types PdSZ 140, PdSZ 170, PdSZ 200, PdSZ 216, PdSZ 245, PdSZ 270]. Kemerovo, 2010. 15. Zaklyuchenie ekspertizy promyshlennoy bezopanosti no. 100-2011 (reg. no. 68-ID-38149-2011 ot 29.11.2011 g.) [Conclusion of industrial safety expertise no. 100-2011 (reg. no. 68-ID-38149-2011 of 29.11.2011) to air-operated blast-hole plugs of types PSZ 140, PSZ 170, PSZ 200, PSZ 216, PSZ 245, PSZ 270 and suspended blast-hole plugs of types PdSZ 140, PdSZ 170, PdSZ 200, PdSZ 216, PdSZ 245, PdSZ 270. Kemerovo, 2011.

16. Zaklyuchenie ekspertizy promyshlennoy bezopanosti no. 78-2010 (reg. no. 07-03-TU-03389-2010 ot 02.08.2010) [Conclusion of industrial safety expertise no. 78-2010 (reg. no. 07-03-TU-03389-2010 of 02.08.2010) to technical documentation for universal sealing devices UZU-140, UZU-170, UZU-200, UZU-216, UZU-245, UZU-270]. Kemerovo, 2010.

17. Zaklyuchenie ekspertizy promyshlennoy bezopanosti no. 51-2011 (reg. no. 68-ID-39428-2011 ot 23.06.2011 g.) [Conclusion of industrial safety expertise no. 51-2011 (reg. no. 68-ID-39428-2011 of 23.06.2011) to universal sealing devices of types UZU-140, UZU-170, UZU-200, UZU-216, UZU-245, UZU-270]. Kemerovo, 2011. 


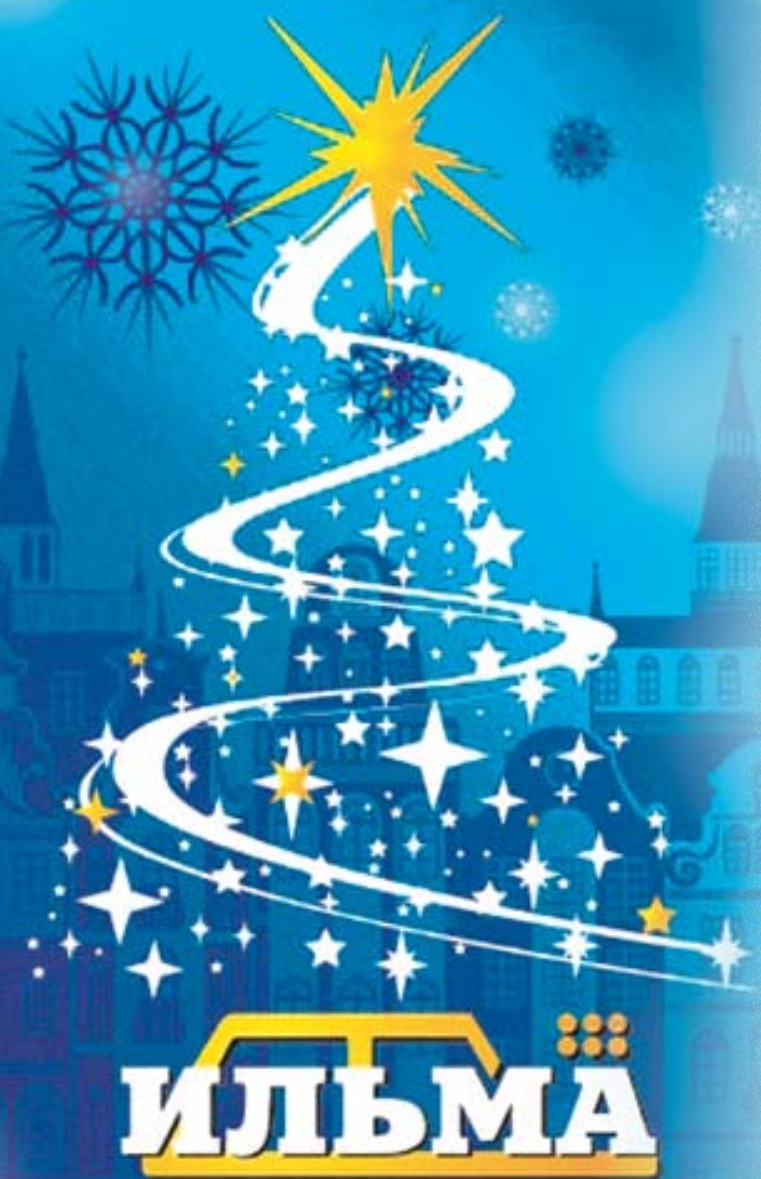

\title{
Уважаемые ветераны и работники угольной отрасли, коллеги и партнеры!
}

\section{От лица коллектива «МК «Ильма» примите искренние поздравления С НАСТУПАЮЩИМ НОВЫМ 2016 ГОДОМ!}

\begin{abstract}
Новый Год - один из самых светлых и самых любимых праздников в году, который объединяет нас вокруг главных ценностей: любви к близким, к своему делу, своему дому, городу, стране. Каждый из нас встречает его с верой в самое доброе и светлое.

Уходящий 2015 год принес нам большие и маленькие победы и достижения, подарил нам радость встреч и открытий, новый бесценный жизненный опыт.

Каким будет наступающий год - во многом зависит от нас с Вами: от нашей целеустремленности, желания работать, реализовывать новые проекты и решать профессиональные задачи.

Уверены, что наша совместная слаженная работа будет способствовать достижению новых вершин и, благодаря объединению усилий, мы сможем добиться положительных результатов.

В преддверии Нового года желаем Вам ставить интересные цели, искать и находить творческие пути решения задач, получать удовольствие от результатов своего труда.

Здоровья, радости и благополучия Вам и Вашим близким! Пусть в Новом году Вам сопутствует удача, в домах всегда царят уют и душевный покой!

А.П. Семешов

Исполнительный директор 000 «МК «Ильма»
\end{abstract}

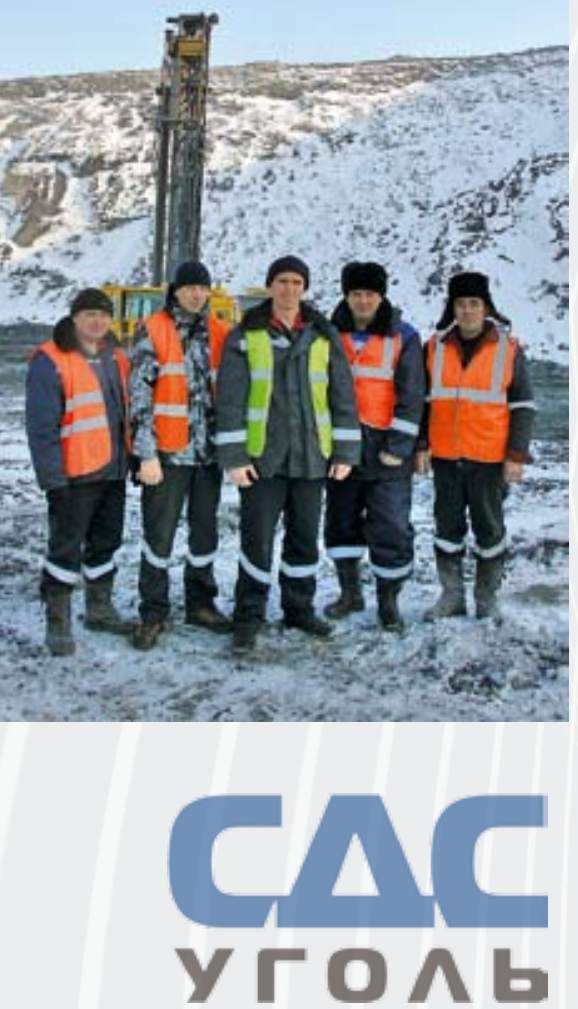

Пресс-служба АО ХК «СДС-Уголь» информирует Всероссийский рекорд кузбасских буровиков

По итогам октября 2015г. две буровые бригады ООО «Азот-Черниговец» (АО ХК «СДС-Уголь») достигли максимального показателя в бурении за всю историю предприятия, а также установили рекорд России буровыми установками DM-45 №9074 и Т4-ВН №8777.

Бригада буровой установки DM-45 №9074 под руководством бригадира Евгения Козлова, ведущая буровые работы в 3 АО «Прокопьевский угольный разрез», достигла показателя в объеме более 39 тыс.м (39 279 м). Коллектив буровиков под руководством Евгения Штырца (Т4-ВН №8777) обслуживающий разрез «Первомайский» (ООО «Шахтоуправление «Майское») приплане 14,3 тыс. мдостиглипоказателяв 20,1 тыс.м. Это лучшие показатели среди машин данного типа в России.

«Достигнутый показатель - это результат слаженной работы нашего дружного коллектива, - говорит генеральный директор ООО «Азот-Черниговец» Владислав Борисенко. - Залогом достижения рекордных показателей стали высокопрофессиональная работа инженерно-технического состава и качественное обеспечение подготовки площадей под бурение».

Всего за 10 мес. 2015 г. ООО «Азот-Черниговец» превысило плановые показатели в бурении на 176,8 тыс. М.

Наша справка.

АО ХК «СДС-Уголь» входит в тройку лидеров отрасли в России. По итогам 2014 года предприятия компании ХК «СДС-Уголь» добыли 28,5 млн т угля. $88 \%$ добываемого угля поставляется на экспорт. АО ХК «СДС-Уголь» является отраслевым холдингом АО ХК «Сибирский Деловой Союз». В зону ответственности компании входят 16 предприятий, расположенных на территории Кемеровской области. 


\section{Кафедре «0ткрытые горные работы» КузГТУ — 60 лет!}

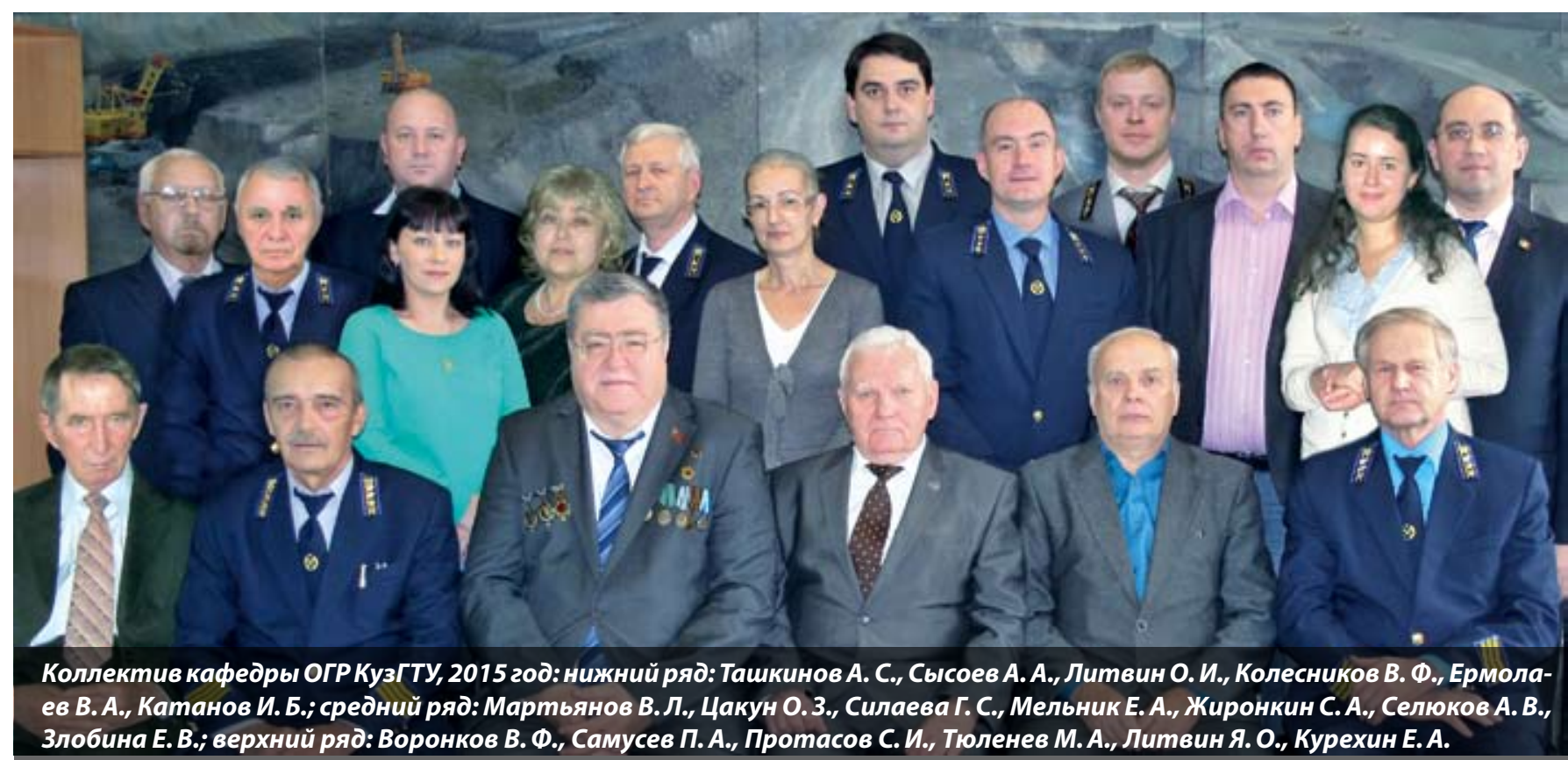

21 ноября 2015 г. в КузГТУ прошли юбилейные мероприятия, посвященные 60-летию старейшей в Сибири кафедры «Открытые горные работы», созданной в 1955 г. в Кемеровском горном институте приказом Минвуза СССР от 31 декабря 1955 № 1270 при поддержке академика Н.В. Мельникова. В ходе юбилея выпускники кафедры разных лет вновь оказались в атмосфере студенческой молодости, посетили учебные аудитории, геологический и университетский музеи, пообщались спреподавателями, сегодняшними студентами и выпускниками разных лет. Состоялась научно-практическая конференция, на которой наряду с воспоминаниями выпускников и преподавателей заинтересованно обсуждались проблемы подготовки современных горных инженеров-открытчиков.

За 60 лет кафедрой подготовлено 3309 горных инженеров-открытчиков, при этом 206 из них получили диплом «с отличием»; проведена профилизация полутора десятков тысяч горных инженеров-маркшейдеров, инженеров-механиков, инженеров-экономистов, специалистов по физическим процессам горного производства и промышленной безопасности. Выпускниками кафедры защищено 80 кандидатских и 12 докторских диссертаций.

Творческий микроклимат на кафедре создавали первый заведующий доцент М. М. Березняк, доценты Б. Т. Рутковский, Е.И. Васильев, А.И. Кожевников, А.В. Калинин, И.И. Цепилов, В. М. Мазаев, Вал. Г. Проноза, профессора Н. Я. Репин, Н. Г. Дубынин, А.С. Ташкинов, В. Ф. Колесников, А.И. Корякин, В.Г. Проноза, их дела продолжает сегодняшний коллектив кафедры.

Выпускники кафедры успешно трудятся на разрезах и карьерах Кузбасса, России, ближнего и дальнего зарубежья, в НИИ и ВУЗах, в органах государственной власти, являются депутатами разного уровня.

Кафедра благодаря помощи угольных компаний Кузбасса поддерживает в хорошем состоянии учебные аудитории, в которыхустановлены современные аудиовизульные средства, регулярно обновляется компьютерный класс, в результате студенты имеют возможность обучаться с использованием современных технических средств.
С 1981 г.для студентов-открытчиков начата и благодаря помощи ОАО «УК «Кузбассразрезуголь» и ОАО «СДС Уголь» продолжает реализовываться специальная дополнительная программа обучения, позволяющая студентам 3 курса получать III группу допуска по электробезопасности до и свыше 1000 B, а также рабочую профессию помощника машиниста экскаватора. Это повышает эффективность проведения производственных практик и качество подготовки будущих горных инженеров, а предприятия имеют возможность в период производственных практик предоставлять своим работникам отпуска в наиболее благоприятные летние месяцы. Ведется также подготовка студентов по программе на «Единую книжку взрывника».

На кафедре на протяжении многих лет развивается несколько направлений научных исследований по совершенствованию техники и технологии открытой угледобычи при минимальной экологической нагрузке. На основании исследований преподавателями кафедры опубликованы 26 монографий; разработаны 19 нормативно-методических документов, используемых в угольной промышленности; изданы 55 учебных пособий; большое количество научных статей в центральных журналах. Научные рекомендации внедрены на производстве, в проекты разрезов и вучебный процесс при чтении курсов по специальным предметам, а также при дипломном проектировании. Коллектив кафедры активно откликается на поставленные жизнью вопросы и вносит свой вклад в развитие горной науки, прежде всего осуществляя подготовку квалифицированных специалистов нового уровня, мышление которых соответствует требованиям современного состояния общества и производства.

Богатство недр Кузбасса и соседних регионов, пригодных для дальнейшего развития открытого способа добычи угля и других полезных ископаемых, предполагает устойчивый спрос на кадры горных инженеров-открытчиков, поэтому кафедра уверенно смотрит в свое будущее.

Репин Н. Я., Ташкинов А. С., Колесников В.Ф., Протасов С.И., Литвин О.И. заведующие кафедрой ОГР КузГТУ разных лет 


\section{Совместная разработка}

\section{сближенных пологих каменноугольных}

\section{пластов в разнопрочных и мерзлых вмецаюцих породах}

DOI: http://dx. doi. org/10.18796/0041-5790-2015-12-34-38

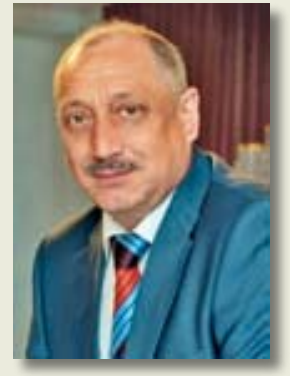

\section{ДОБРОВОЛЬСКИЙ} Александр Иванович

Исполнительный директор

ОАО «Ургалуголь»,

канд. техн. наук, 682030,

п. Чегдомын, Хабаровский край,

Россия, тел.: + 7 (42149) 5-17-68,

e-mail:DobrovolskiyAl@suek.ru
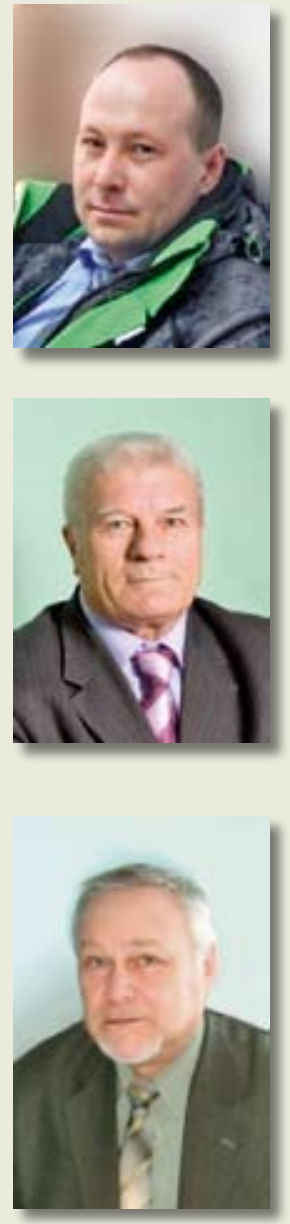

ГАЛИМьянОВ Алексей Алмазович Горный инженер, ОАО «Ургалуголь», 682030, n. Чегдомын, Хабаровский край, Россия, тел.: +7 (42149) 5-23-38, e-mail: Galimyanovaa@suek.ru

\section{ШЕВКУН Евгений Борисович}

Профессор кафедры «Транспортнотехнологические системы в строительстве и горном деле» Тихоокеанского государственного университета, доктор техн. наук, 680035 , г. Хабаровск, Россия, тел.: + 7 (4212) 375-202, e-mail:ev.shevkun@yandex.ru

\section{ЛЕЩИНСКИЙ}

\section{Александр Валентинович}

Профессор кафедры «Транспортнотехнологические системы в строительстве и горном деле» Тихоокеанского государственного университета, доктор техн. наук, 680035, г. Хабаровск, Россия, тел.: +7 (4212) 375-202, e-mail:lesch@sdm.khstu.ru
Приведены результаты экспериментальных массовых взрывов с одновременным взрывным рыхлением пород вскрыши над угольным пластом и под ним при сохранении положения пласта в пространстве. Валовое взрывание позволяет снизить затраты исключением нарезания площадок под повторное бурение и снижением расхода взрывчатых материалов.

Ключевые слова: валовое взрывание, массовый взрыв, угольный пласт.

На разрезе «Буреинский-2» ОАО «Ургалуголь» в период с 21.05.2015 по 27.10.2015 проведено пятнадцать экспериментальных массовых взрывов по новой рациональной технологии совместной разработки сближенных пологих пластов каменного угля в разнопрочных и мерзлых вмещающих породах, представленных песчаником на глинистом цементе, алевролитами VI-VII категорий крепости по СНиП (коэффициент крепости по шкале М.М. Протодьяконова $f=4-6)$.

Цель эксперимента - оценка возможности применения валового взрывного рыхления разнопрочных и мерзлых вскрышных пород одновременно над угольными пластами и под ними с сохранением пространственного положения угольных пластов сложного строения для последующей их селективной разработки механическим рыхлением и выемкой бульдозером.

Традиционная технология разработки угольных пластов на разрезе «Буреинский-2» производится механическим рыхлением с последующей выемкой бульдозером последовательно в девять этапов по мере рыхления взрывным способом вмещающих скальных пород вскрыши для подготовки их к выемке (рис. 1).

Этап 1. Обуривание горизонтальной поверхности вскрышных пород блока №1, взрывное рыхление и выемка взорванной горной массы.

Этап 2. Механическое рыхление и выемка бульдозером угольных пластов B13-B14 (puc. 2, a).

Этап 3. Обуривание горизонтальной поверхности вскрышных пород блока №2, взрывное рыхление и выемка взорванной горной массы.

Этап 4. Формирование при помощи бульдозера технологических площадок (полок) для бурения взрывных скважин на блоке №3 (см. puc. 2, б). 


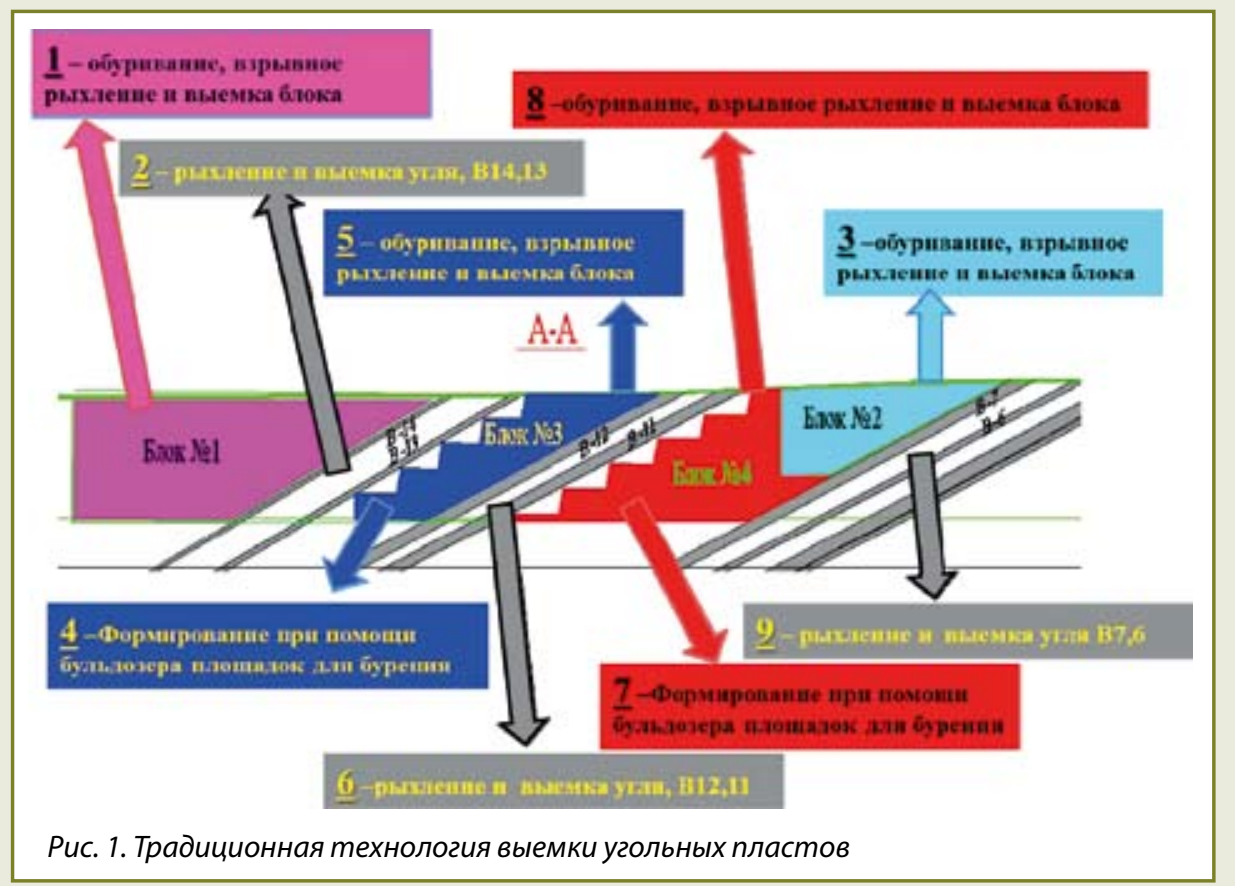

онной, применяемой на разрезе, рассмотрим на примере одного из экспериментальных массовых взрывов (рис. 5).

По рациональной технологии совместной разработки сближенных пологих пластов каменного угля в разнопрочных и мерзлых вмещающих породах проводится валовое рыхление вмещающих пород массовым взрывом одного технологического блока (рис. 6).

Селективная послойная выемка угольных пластов после валового взрывного рыхления производится путем механического рыхления и бульдозирования в навал одновременно с экскаваторной выемкой пород вскрыши по мере обнажения пластов угля (рис. 7).

При валовом рыхлении массива

Этап 5. Обуривание вскрышных пород блока №3 с размещением бурового и зарядного оборудования на узких технологических площадках, взрывное рыхление и выемка вскрышных пород блока. На этом этапе возникает в скважинных зарядах под угольными пластами необходимо обеспечить взрывное рыхление с минимальным воздействием на угольный пласт с целью сохранения его пространственного положения для последующей опасная производственная ситуация (ОПС) [1], поскольку для обуривания взрывными скважинами породных перемычек (рис. 3) между угольными пластами требуется сформировать дополнительные технологические площадки (полки) при помощи бульдозера.

Полки формируются узкими и создают ОПС как при бурении первого ряда скважин, так и при дальнейшем заряжании скважин (рис. 4).

Этап 6. Механическое рыхление и выемка бульдозером угольных пластов В11-В12.

Этап 7. Формирование при помощи бульдозера технологических площадок (полок) для бурения взрывных скважин на блоке №4.

Этап 8. Обуривание вскрышных пород блока №4 с размещением бурового и зарядного оборудования на узких технологических площадках, взрывное рыхление и выемка вскрышных пород блока.

Этап 9. Механическое рыхление и выемка бульдозером угольных пластов В7-В6.

Основное отличие новой рациональной технологии совместной разработки сближенных пологих пластов каменного угля в разнопрочных и мерзлых вмещающих породах от традици-

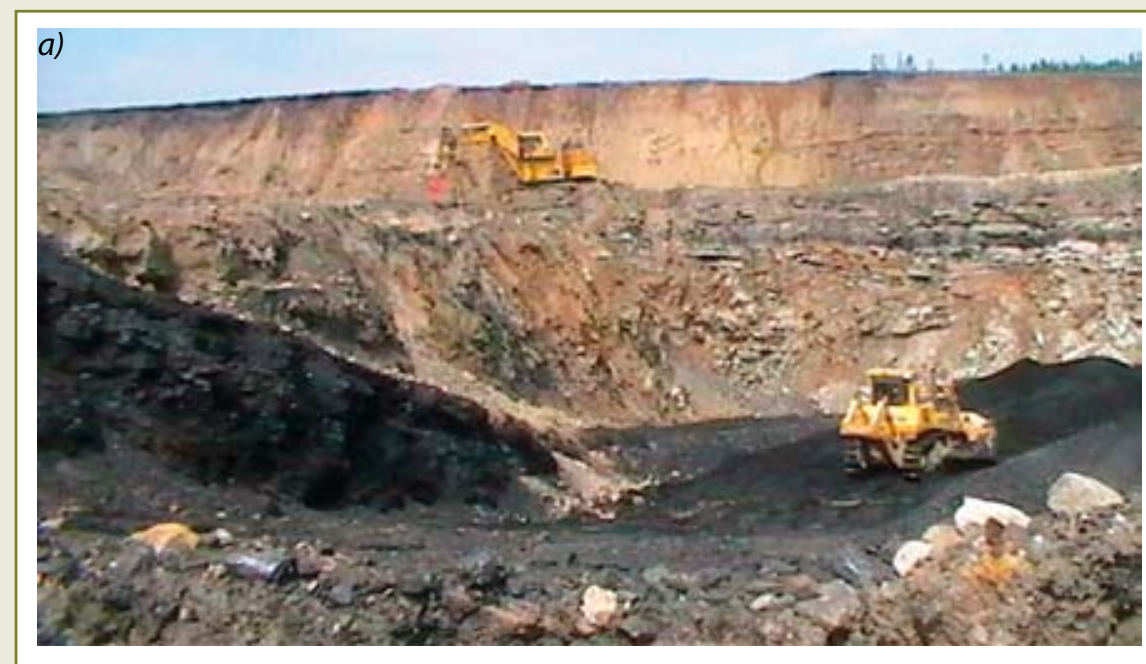

б)

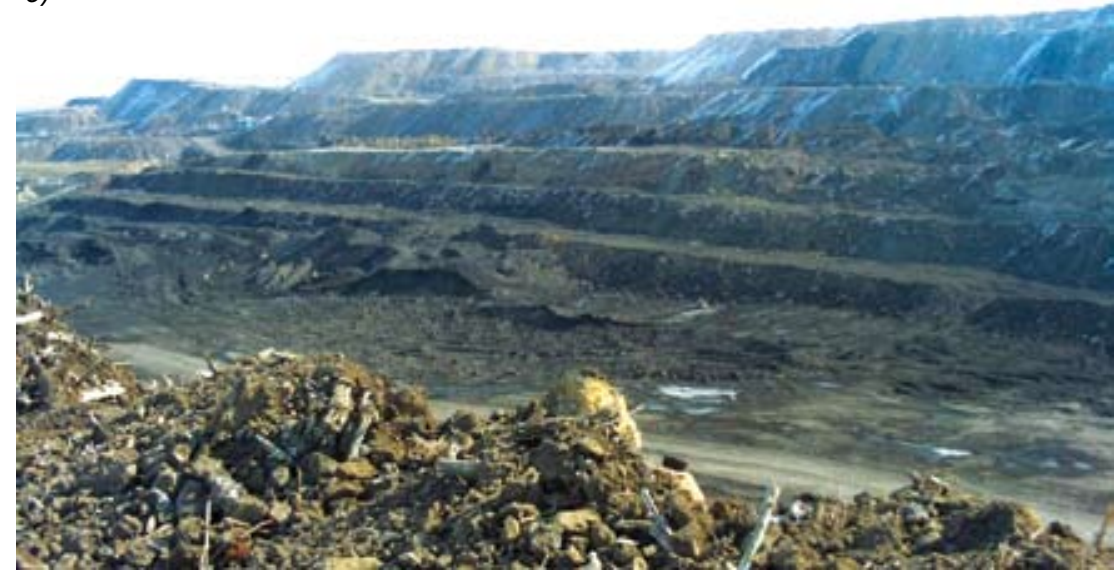

Puс. 2. Выемка угля (а) и сформированные полки для обуривания блока (б) 


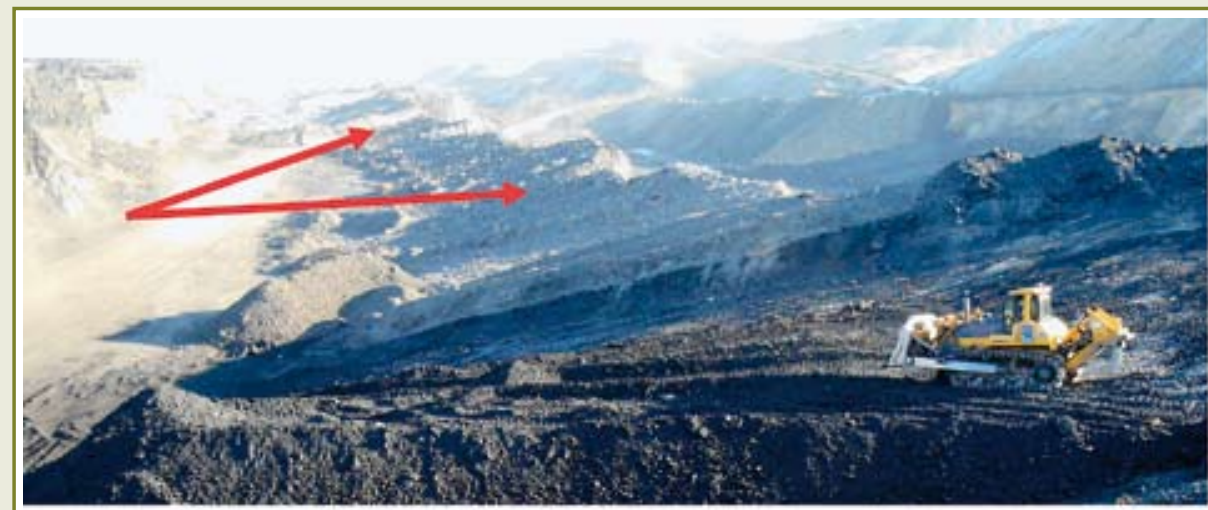

Рис. 3. Породная перемычка, остающаяся при традиционной выемке угольных пластов
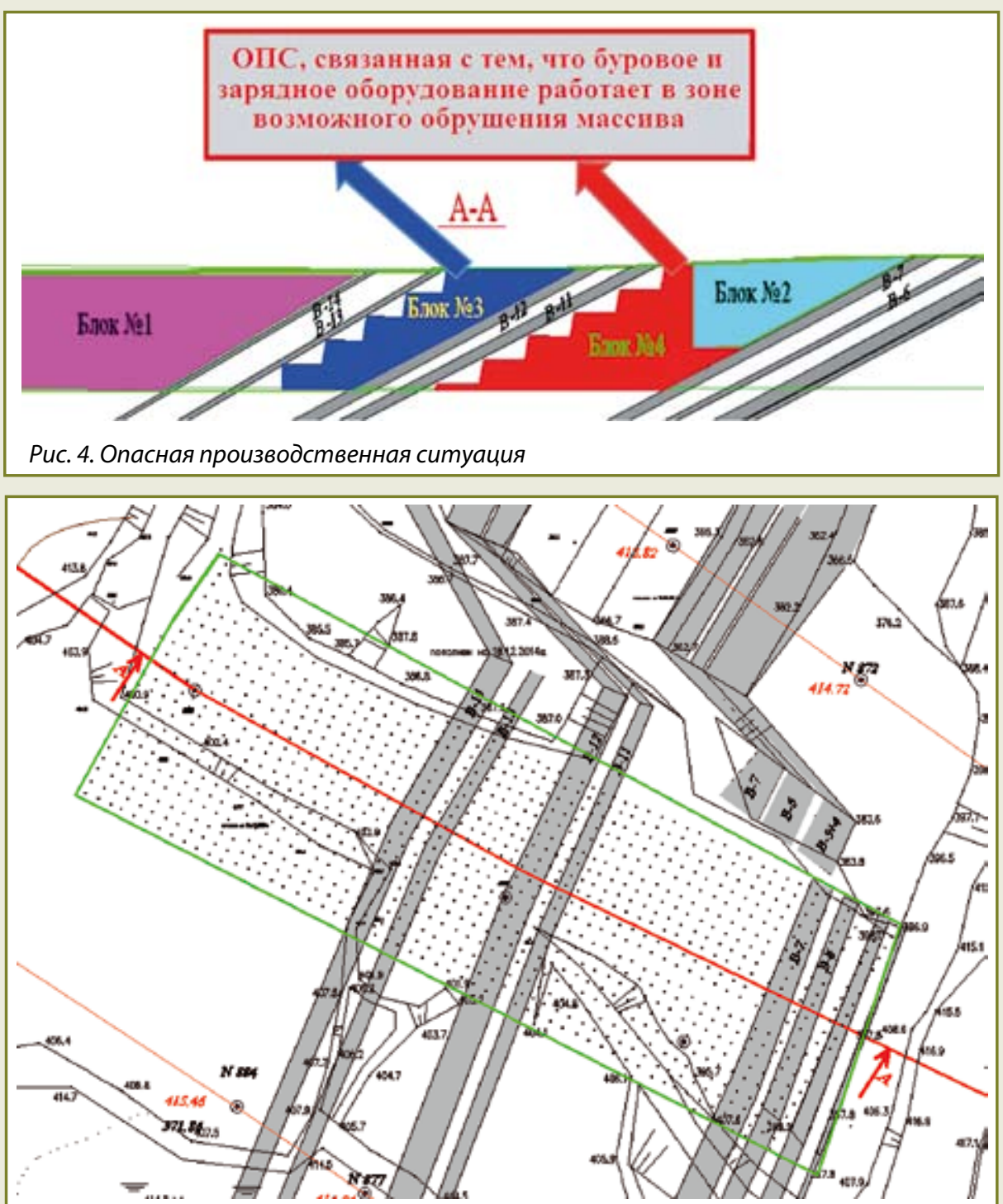

Puc. 5. Расположение скважин на одном из экспериментальных блоков в плане

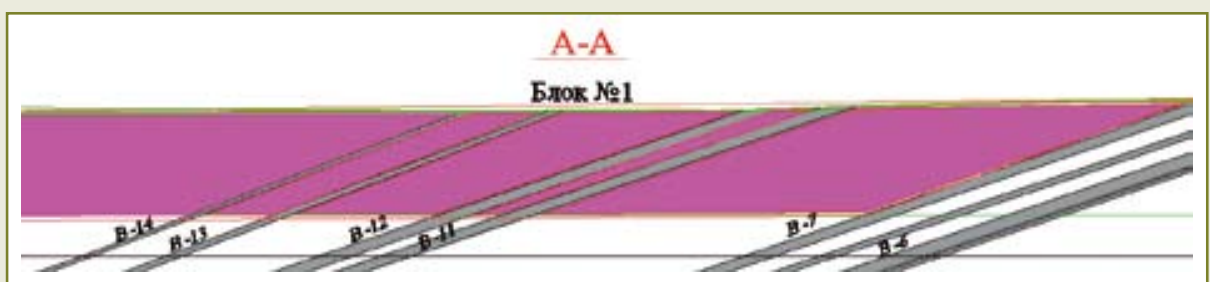

Рис. 6. Рациональная технология выемки пологих угольных пластов селективной выемки, поскольку пласты имеют сложное строение. Такое взрывное рыхление может быть обеспечено камуфлетным взрыванием. За счет этого эффекта происходит разупрочнение угольного пласта под действием волн напряжений при сохранении его пространственного положения, что облегчает дальнейшую селективную выемку угля, при этом не выявлено разубоживание угля. Кроме того, при валовом взрывании исключаются дополнительные технологические процессы по буровзрывным работам на «перемычках» между пластами и связанные с ними ОПС.

Эффект камуфлетного взрывания обеспечивается благодаря высоким запирающим свойствам короткой комбинированной забойки [2].

По результатам проведения пятнадцати экспериментальных массовых взрывов подготовки массива к выемке методом валового взрывания установлено следующее:

- доказано, что методом валового взрывания возможно рационально подготавливать вскрышные породы к выемке без разубоживания и потерь угля. На puc. 8, а показано положение блока до взрыва, на рис. 8, б - после взрыва: видна неубранная горная масса (выделено овалом 1), вспученная горная масса сектора 1 над угольным пластом В-14 (овал 2), недеформированная поверхность пласта В-14 сектора 2 (овал 3);

- установлено, что при такой схеме рациональной подготовки массива к выемке угольный пласт частично разупрочняется, это облегчает селективную выемку угля бульдозером, а также снижает выход крупных кусков угля, что благоприятно сказывается на работе обогатительной фабрики. На рис. 7, а видны трещины по напластованию в угольном пласте B-14, но положение пласта в пространстве сохранено, что позволило отработать его послойно с помощью бульдозера с рыхлителем (см. рис. 7, б); 
- снижен на $38 \%$ удельный расход $\mathrm{BB}$ - с 0,85 до $0,61 \mathrm{kг} / \mathrm{M}^{3}$ (см. табличу);

- одновременное взрывание породы над угольным пластом и под ним позволило исключить ОПС (см. рис. 3,4), связанную с оставлением перемычек между угольными пластами при традиционном способе взрывания;

- за счет снижения удельного расхода ВВ уменьшен радиус воздействия ударной воздушной волны и разлета кусков породы, а также снижена высота развала взорванной горной массы.

Основные показатели экспериментальных массовых взрывов сведены в таблицу, откуда следует, что при пла-

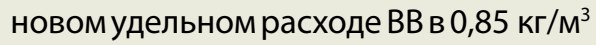
и фактическом 0,61 кг/м³ расход взрывчатых материалов снижен на 587,8 т, а экономический эффект от этого снижения составил 16,57 млн руб.

Удельная экономия по ВГМ составила 7,07 руб. /М³. Ориентировочный экономический эффект за счет исключения поэтапного взрывного рыхления с нарезанием полок под бурение составил 7,07·2442 = 17,262 млн руб.

Переход с поэтапного взрывного рыхления на валовое позволил исключить:

— подготовительные бульдозерные работы (нарезание полок) для отдельного производства БВР в секторе №2 (лежачий породный бок относительно угольного пласта В14 на рис. 1) и сектора №3 (лежачий породный бок относительно угольного пласта В12 на рис. 1);
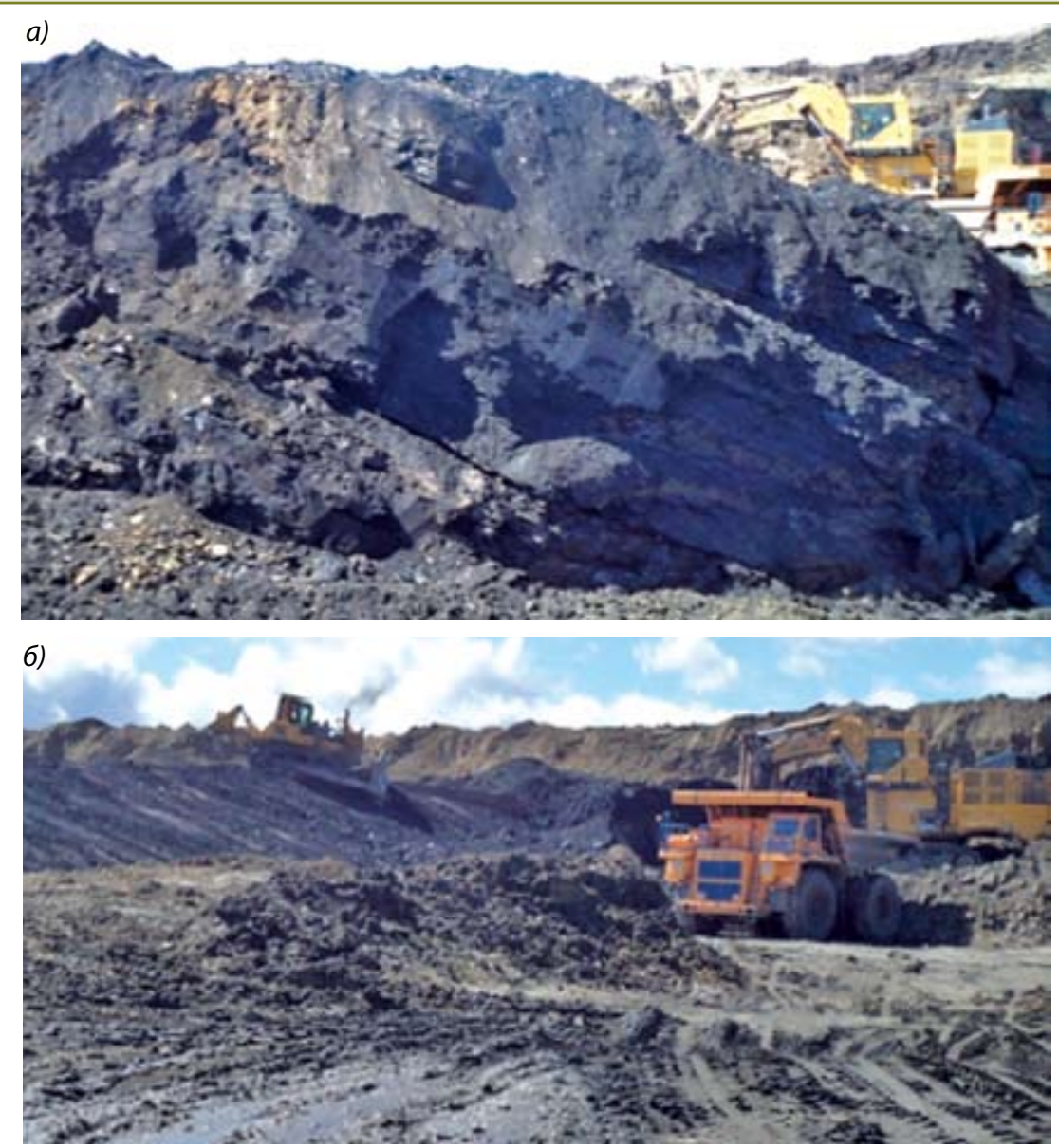

Puc. 7. Вид пласта B-12 после взрыва (а) и его отработка (б)
- операции по подготовке забоя от развала породы взрывами двух секторов в разное время (поскольку три сектора взорваны одновременно, соответственно, исключается разброс кусков породы от отдельных взрывов двух секторов);

\section{Показатели экспериментальных массовых взрывов}

\begin{tabular}{|c|c|c|c|c|c|c|c|}
\hline $\begin{array}{c}\text { № } \\
\text { взрыва }\end{array}$ & $\begin{array}{c}\text { Дата } \\
\text { взрыва }\end{array}$ & $\begin{array}{c}\text { Объем ВГМ, } \\
\text { тыс. } \text { м }^{3}\end{array}$ & $\begin{array}{c}\text { Расход } \\
\text { ВВ, T }\end{array}$ & 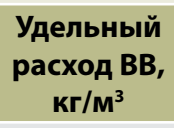 & $\begin{array}{c}\text { Затраты } \\
\text { на ВМ, } \\
\text { тыс. руб. }\end{array}$ & $\begin{array}{c}\text { Средний размер } \\
\text { фракции куска } \\
\text { ВГМ, м }\end{array}$ & $\begin{array}{c}\text { Воздействие } \\
\text { на угольный пласт, } \\
\text { разубоживание \% }\end{array}$ \\
\hline 1 & 21.05 .2015 & 85 & 48,4 & 0,57 & 1198 & 0,35 & 0 \\
\hline 2 & 27.05.2015 & 143 & 74,5 & 0,52 & 2111 & 0,33 & 0 \\
\hline 3 & 29.06.2015 & 232 & 103,4 & 0,45 & 2932 & 0,32 & 0 \\
\hline 4 & 10.07.2015 & 173 & 74,8 & 0,43 & 2309 & 0,37 & 0 \\
\hline 5 & 25.07.2015 & 179 & 92,2 & 0,52 & 2695 & 0,31 & 0 \\
\hline 6 & 28.07.2015 & 103 & 44,1 & 0,43 & 1715 & 0,29 & 0 \\
\hline 7 & 06.08.2015 & 133 & 76,5 & 0,58 & 1898 & 0,25 & 2,1 \\
\hline 8 & 18.08.2015 & 68 & 50,2 & 0,74 & 1545 & 0,23 & 0,5 \\
\hline 9 & 28.08.2015 & 517 & 291 & 0,56 & 8126 & 0,25 & 0 \\
\hline 10 & 18.09.2015 & 82 & 54,5 & 0,66 & 1384 & 0,23 & 0 \\
\hline 11 & 25.09 .2015 & 45 & 29,4 & 0,65 & 848 & 0,23 & 0 \\
\hline 12 & 05.10 .2015 & 131,5 & 76,4 & 0,58 & 2870 & 0,27 & 0 \\
\hline 13 & 15.10 .2015 & 116,5 & 83,8 & 0,72 & 2541 & 0,22 & 0 \\
\hline 14 & 21.10 .2015 & 213 & 166,7 & 0,78 & 3971 & 0,21 & 0 \\
\hline 15 & 27.10 .2015 & 221 & 222 & 1,00 & 5803 & 0,25 & 0 \\
\hline Итого: & & 2442 & 1487,9 & 0,61 & 41946 & 0,27 & - \\
\hline
\end{tabular}


- отвод техники за пределы опасной зоны радиусом 650 м и общий простой карьера на проведение двух массовых взрывов (в секторах 2 и 3).

Суммарный экономический эффект от проведения пятнадцати экспериментальных взрывов составил 33,8 млн руб.

\section{вывод}

Рациональный метод подготовки массива к выемке путем взрывания породных перемычек под угольным пластом позволил снизить общие затраты на выемке горной массы и БВР, а также устранить ОПС, связанные с дополнительным рыхлением данных перемычек буровзрывным способом.

\section{Список литературы}

1. Карта боя с опасными производственными ситуациями. Приложение №1 к практическому пособию «Безопасность производства (организационный аспект)»/ В.Б. Артемьев, В.А. Галкин, И.Л. Кравчук и др. // Горный информационно-аналитический бюллетень (научно-технический журнал). 2015. №5 (спец. выпуск 21). 40 с.

2. Шевкун Е.Б., Лещинский А. В. Комбинированная забойка взрывных скважин на карьерах. Хабаровск: Изд-во Тихоокеанского государственного университета, 2013. 201 c.
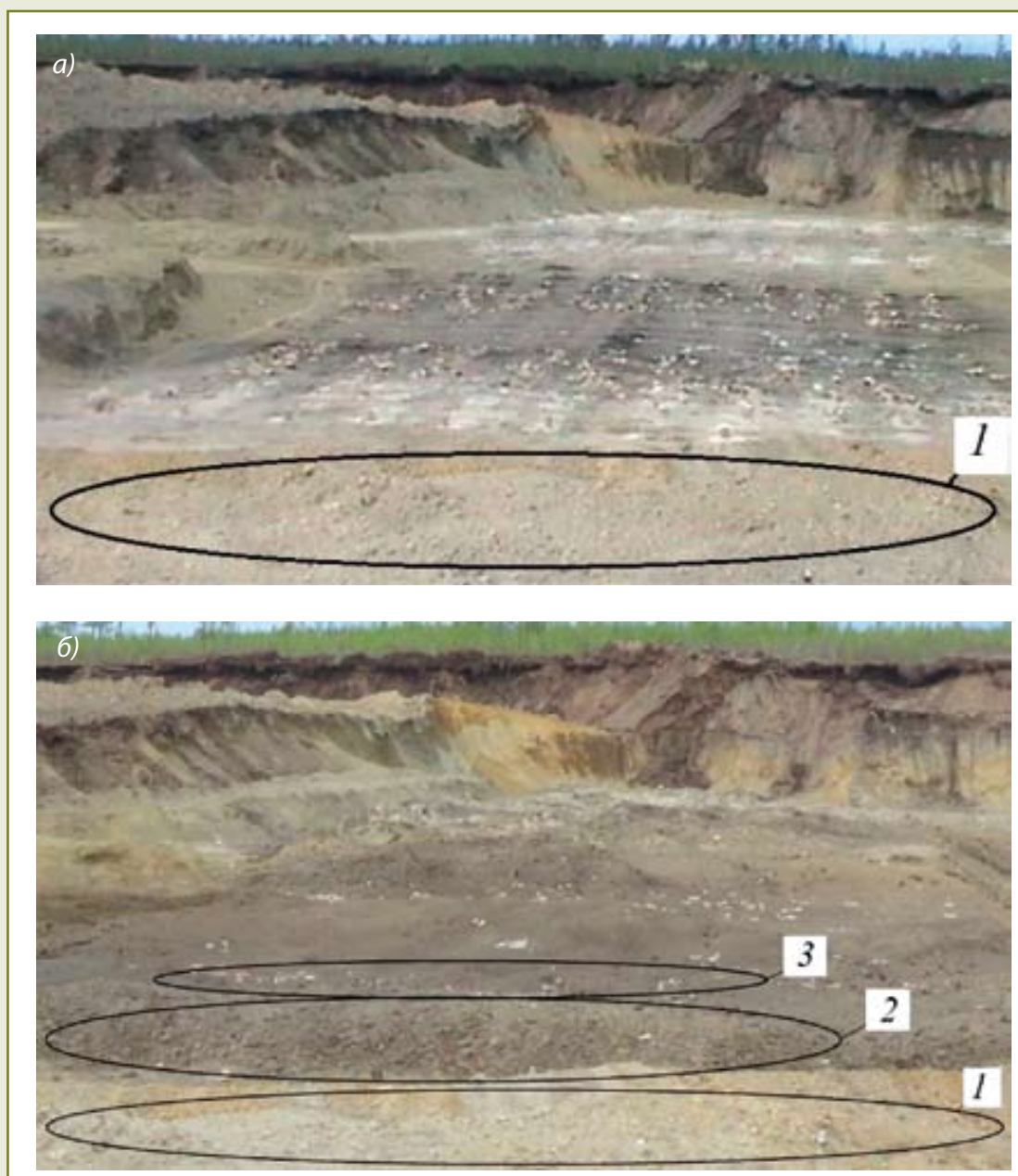

Puс. 8. Экспериментальный блок до взрыва (а) и после (б)

UDC 622.271:622.235 @ A.I. Dobrovolsky, A. A. Galimyanov, E. B. Shevkun, A.V. Leschinsky, 2015

SURFACE MINING

ISSN 0041-5790 (Print) • ISSN 2412-8333 (Online) • Ugol' — Russian Coal Journal, 2015, № 12, pp. 34-38

\section{Title}

\section{DEVELOPMENT OF A GROUP OF COAL SEAMS WITH GROSS EXPLOSIVE LOOSENING OVERBURDEN}

DOI: http://dx. doi. org/10.18796/0041-5790-2015-12-34-38

\section{Authors}

Dobrovolsky A.I. ${ }^{1}$, Galimyanov A. A. ${ }^{1}$, Shevkun E. B. ${ }^{2}$, Leschinsky A.V. ${ }^{2}$

${ }^{1}$ Urgalugol OJSC, set. Chegdomyn, Khabarovsk Region, 682030, Russian Federation

${ }^{2}$ Pacific State University, Khabarovsk, 680035, Russian Federation

\section{Authors' Information}

Dobrovolsky A. I., PhD (Engineering), executive director, tel.: +7 (42149) 5-17-68, e-mail: DobrovolskiyAl@suek.ru

Galimyanov A. A., mining engineer, tel.: +7 (42149) 5-23-38,

e-mail: Galimyanovaa@suek.ru

Shevkun E. B., doctor of engineering Sciences, Professor of the Department "Transport and technological systems in the construction and mining", tel.: +7 (4212) 375-202, e-mail: ev. shevkun@yandex.ru

Leschinsky A.V., doctor of technical Sciences, to the penny, Professor of the Department "Transport and technological systems in the construction and mining", tel.: +7 (4212) 375-202, e-mail: lesch@sdm.khstu.ru

\section{Abstract}

The experimental results of a massive explosion with simultaneous explosive loosening overburden above a coal bed, and under it while maintaining the position of the layer in space. Gross blasting can reduce costs with the exception of the cutting sites for the re-drilling and the decline in the consumption of explosive materials

\section{Keywords}

Gross blasting, blast, coal seam.

\section{References}

1. Artemyev V. B., Galkin V. A., Kravchuk I. L., Makarov A. M., Galkin A.V. Karta boya s opasnymi proizvodstvennymi situatsiyami. Prilozhenie № $1 \mathrm{k}$ prakticheskomu posobiyu “Bezopasnost' proizvodstva (organizatsionnyy aspekt)" [Map of the battle with dangerous production situations. Appendix No. 1 to the practical guide "Safety of production (organizational dimension)"]. Gornyy Informatsionno-Analiticheskiy Byulleten - Mining Information-Analytical Bulletin, 2015, no. 5 (spec. issue 21), $40 \mathrm{p}$.

2. Shevkun E. B., Leschinsky A.V. Kombinirovannaya zaboyka vzryvnykh skvazhin na kar'erakh [Combined tamping blast holes at quarries]. Khabarovsk, the Pacific State University Publ., 2013, 201 p. 


\section{УВАЖАЕМЫЕ КОЛЛЕГИ! \\ От лица многотысячного коллектива холдинговой компании «СДС-Уголь» поздравляем Вас с Новым, 2016 годом!}

Новый год обычно связывают с надеждами на лучшее, поэтому пускай все хорошее, что радовало Вас в уходящем году, непременно найдет свое продолжение в году наступающем.

2015 год был непростым для мира, для России, для Кузбасса, для всей угольной отрасли. К сожалению, не обошли нас стороной глобальные экономические проблемы. Но самое главное - были добрые дела, созидательный труд, общие успехи и победы.

Подводя итоги года уходящего, можно сказать: в целом мы прожили его достойно. За всеми успехами и достижениями нашей отрасли стоят Ваш самоотверженный труд, золотые руки горняков и шахтеров, трепетное отношение к любимому делу и высочайший профессионализм!

В связи со сложнейшими проблемами на мировом рынке 2016 год будет очень напряженным. Но если мы все будем едины, будем помогать друг другу, сохраним выдержку и взаимопонимание, мы пройдем и этот этап. Угольная отрасль и не такое переживала! Главное - верить, что справимся! И тогда черная полоса проблем превратится во взлетную!

По старой горняцкой традиции новогоднюю елку можно зажигать тогда, когда выполнен годовой план. Желаем,

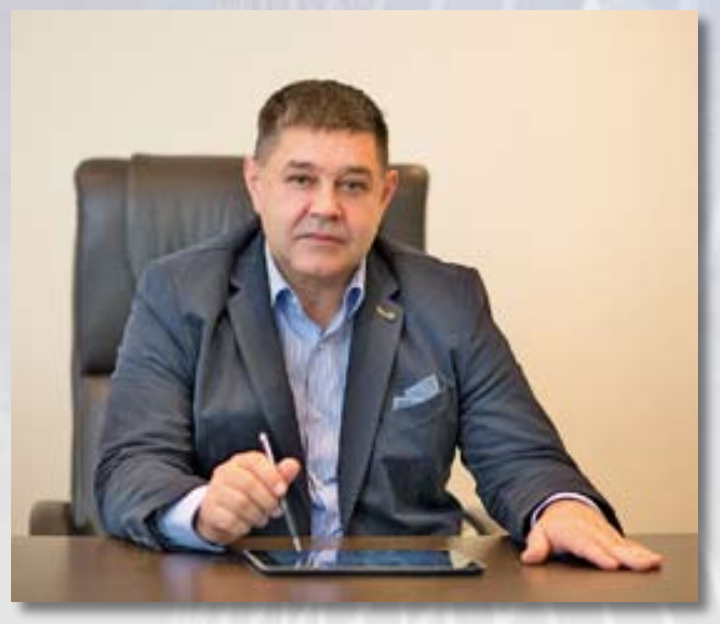
чтобы во Всех трудовых коллективах Новый год прошел под яркий свет символа праздника!

Ю.С. Дерябин, генеральный директор АО ХК «СДС-Уголь»

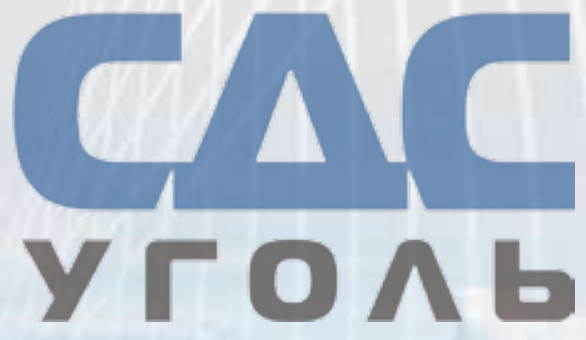

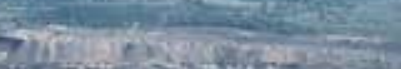
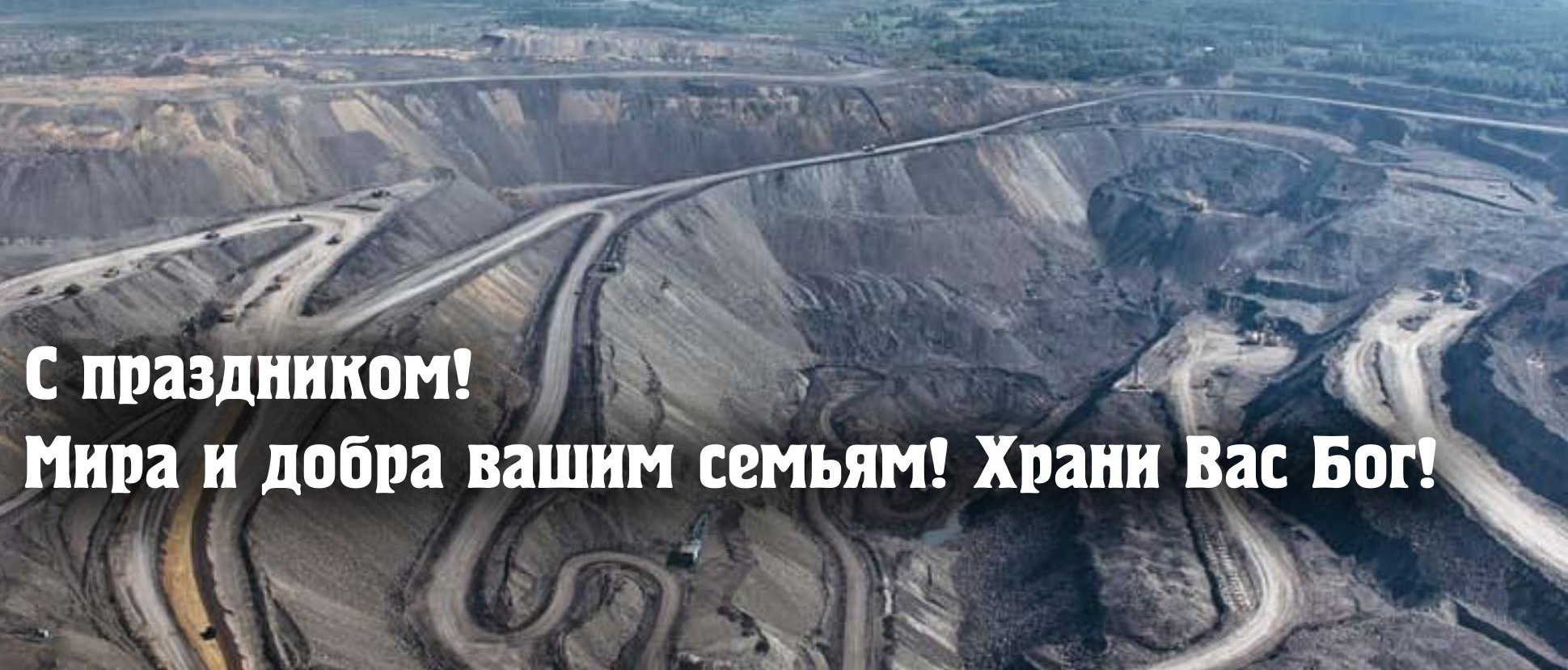


\section{Развитие угледобывающих предприятий Дальнего Востока (за период с 1965 по 2015 г.)}

DOI: http://dx. doi. org/10.18796/0041-5790-2015-12-40-43

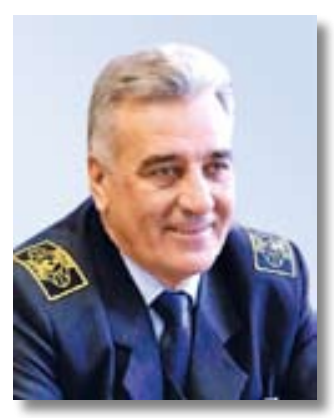

\section{КУРБАНОВ \\ Нурали Хайдарович}

Директор Института экономико-правовых основ недропользования, ФГБОУВПО «Российский государственный геологоразведочный университет имени Серго Орджоникидзе» (МГРИ-РГГРУ), доктор экон. наук, профессор, 117997, г. Москва, Россия

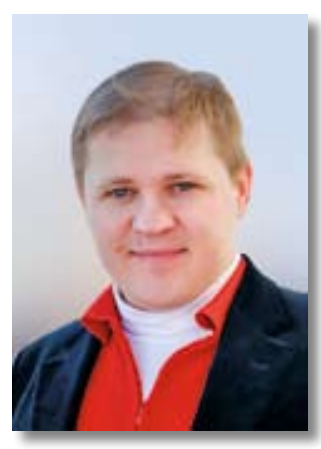

\section{РАФИЕНКО}

\section{Владимир Алексеевич}

Генеральный директор НПП «Фильтроткани», заведующий лабораторией ФГБОУ ВПО «Российский государственный геологоразведочный университет имени Серго Орджоникидзе» (МГРИ-РГГРУ), канд. техн. наук, канд. экон. наук,

117335, 2. Москва, Россия, e-mail:npp-f@yandex.ru

В статье проведен анализ производственных показателей угледобывающих предприятий за период с 1965 по 2015 г., преимущественно характеризующий динамику объемов добычи угля на Дальнем Востоке. Показан потенциал для развития угледобывающих предприятий отдельных областей Дальнего Востока.

Ключевые слова: добыча угля, угольная промышленность, экономическое развитие Дальнего Востока, ТЭК России, рачиональное недропользование.

Угольная промышленность как составляющая ТЭК является основополагающей отраслью народного хозяйства и имеет большое значение в формировании экономического потенциала [1].

Россия занимает второе место после США в мировых запасах угля [1]. Уголь среди твердых полезных ископаемых в секторе ТЭК России занимает первое место [2], угольная промышленность имеет достаточный потенциал для развития. Несмотря на это, уголь как топливо уступает его альтернативным источникам, но все еще остается стратегическим сырьем не только как топливо, но и как сырье металлургической, химической промышленности.

Дальний Восток всегда имел важное экономико-социально-политическое значение и обладает огромным природным, ресурсным и промышленным потенциалом.

Наиболее интенсивный и благоприятный период развития угольной промышленности Дальнего Востока приходится на 1950-1970гг.
Это время характеризовалось ростом объемов добычи угля, совершенствованием процессов разработки месторождений, добычи и переработки, непрерывным наращиванием производственных мощностей и рационализацией организации производства и охраны труда [3].

На рис. 1 представлена динамика объемов добычи угля Дальнего Востока, которая за период с 1965 по 1990 г. выросла на 60,5\% [4].

В 1988 г. она стала максимальной в регионе, тогда былодобыто 57,2 млн т угля. А с началом перестройки в СССР начался резкий спад, и уже к 1989 и 1990 гг. добыча сократилась до 53 и 49 млн т соответственно. Среднегодовые темпы прироста в отрасли в этот период составляли порядка 2,5\%.

Таким образом, период с 1965 по 1985 г. характеризуется как благоприятный период интенсивного развития угольной отрасли, формирования привлекательного социально-экономического положения при освоении территорий в регионе. Анализ данных этого периода свидетельствует о том, что именно в этот период была проведена крупномасштабная работа стратегического значения, которая и по сей день служит мощной основой стабильного развития угольных предприятий Дальнего Востока [3].

Основным поставщиком топлива на Дальнем Востоке до 1980 г. была Амурская область, где добывалось более 14 млн т вгод. Такой объем давали разрезы Райчихинского буроугольного месторождения, а затем Бикинское (Приморье) и Нерюнгринское (Республика Саха (Якутия)) месторождения. До 1990 г. Приморье и Республика Саха (Якутия) добывали 


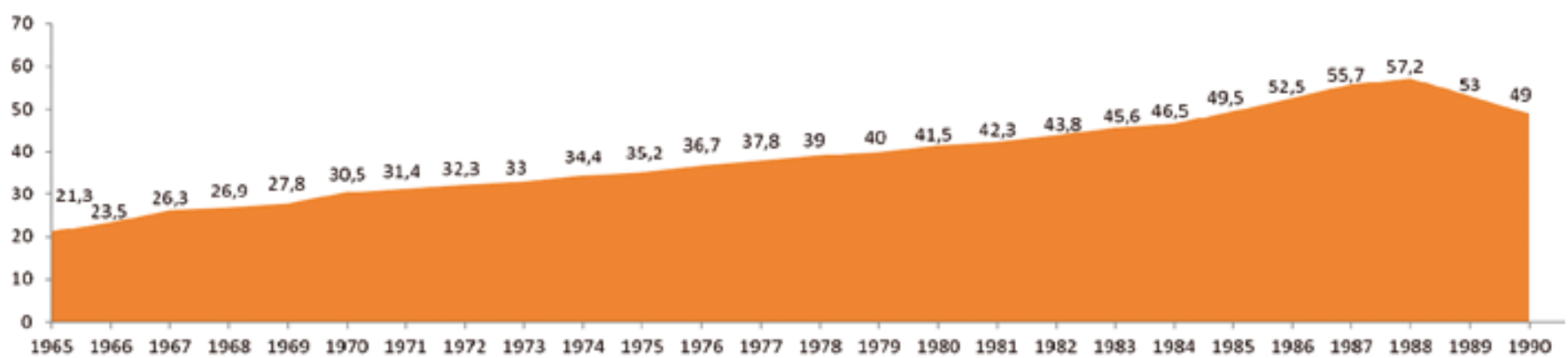

Puс. 1. Динамика добычи угля на Дальнем Востоке за 1965-1990 г2., млн m

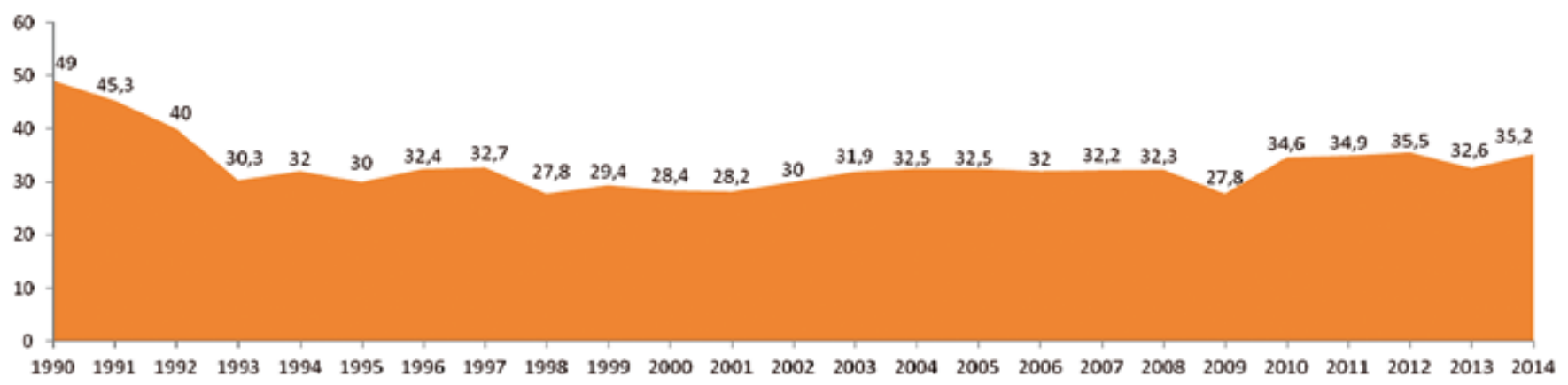

Puc. 2. Динамика добычи угля на Дальнем Востоке за 1990-2014 г2., млн $m$

более 32 млн т угля, их суммарная добыча на Дальнем Востоке составляла $63 \%$ К К 2000 г. суммарная добыча угля в Приморье и Якутии снизилась примерно до 18 млн т, при этом вследствие сильного спада в других регионах их общая составляющая добычи угля выросла до 70\% [5].

Начавшееся в 1988 г. падение объемов добычи угля на Дальнем Востоке и в целом по России положило начало технологическому кризису в угольной промышленности, что привело к обострению социально-экономической обстановки в отрасли.

За период с 1990 по 1998 г. добыча снизилась более чем в 1,5 раза, были закрыты многие шахты. Необходимо

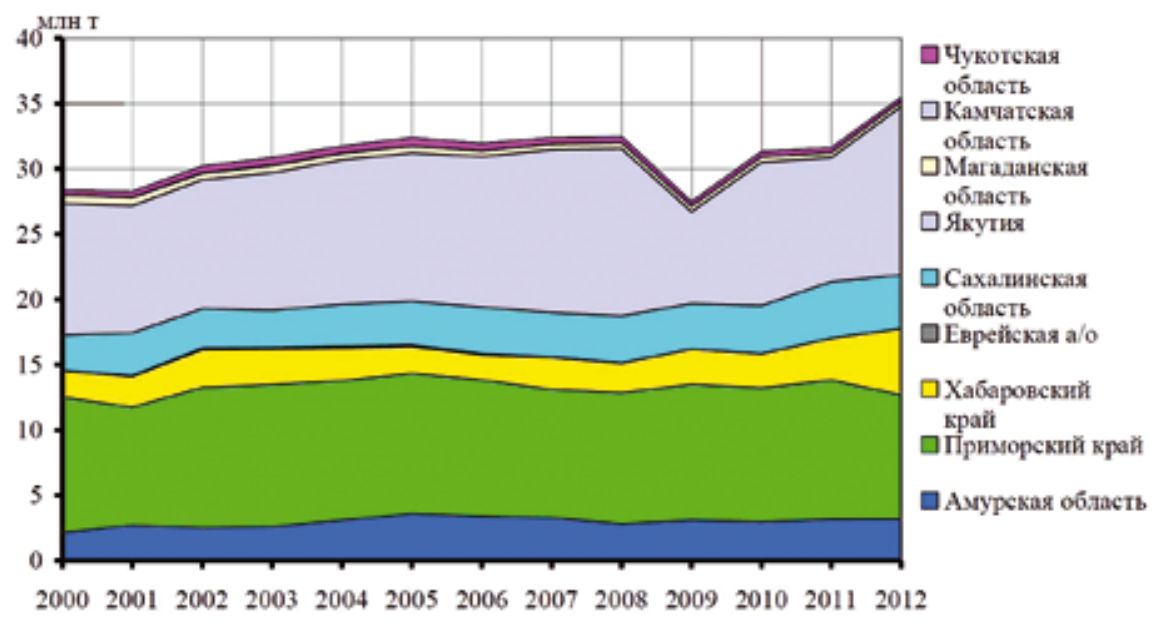

Pис. 3. Динамика изменения добычи угля на Дальнем Востоке за 2000-2012 г2. по областям [7]

отметить, что темпы сокращения добычи угля на Дальнем Востоке были ниже, чем в других регионах России. Это позволило региону сохранить относительно высокий уровень в общероссийской добыче угля ( 12\%).

Спад добычи угля на Дальнем Востоке продолжался до 2000 г. (рис. 2), затем положение в угольной промышленности региона стабилизировалось, появилась положительная динамика в сторону роста добычи угля в регионе.

Особенно стоит отметить период с 2000 по 2010 г., когда наблюдался ежегодный рост, в 2005 г. наблюдается максимум по объемам добычи угля - 32,5 млн т, а с 2005 по 2009г. наблюдается незначительное снижение. В 2009 г. зафиксирован минимальный показатель, что сравнимо только с показателями начала 2000-хгг. С 2010 по 2013 г. объемы добычи возобновили рост с 34,6 до 35,5 млн т соответственно. Показатели в 35,2 млн т в 2014 г. и 17,9 млн т в первом полугодии 2015 г. (на 2,3\% больше, чем за аналогичный период прошлого года) свидетельствуют о положительной динамике в настоящее время [6].

В 2012 г. темп роста к уровню 2000 г. составил 125,1\% (puc. 3) $[6,7]$.

На территории Дальневосточного федерального округа (ДВФО) сосредоточено $26 \%(1,2$ трлн т) запасов и ресурсов углей от общероссийских $[7,8]$. Сырьевая база угольной промышленности ДВФО представлена бурыми (60\%), коксующимися (20,8\%) и каменными (19,2\%) углями, балансовые запасы которых по категориям $\mathrm{A}+\mathrm{B}+\mathrm{C} 1$ составляют от общероссийских около $10 \%$ (20,2 млрд т) $[1,8]$. Большая часть ценных углей, залегает в Республике Саха (Якутия), это более $30 \%$ запасов России [1, 7, 8], известно около 900 угольных месторождений, $60 \%$ 
основных запасов пригодно к разработке открытым способом.

На северо-западе Якутии, в Ленском угольном бассейне имеется максимальная концентрация угольных залежей, однако недостаточно развитая инфраструктура в районе бассейна реки Лены сдерживает наращивание объемов добычи в этом районе, и его перспективы будут связаны, в частности, с его демографической ситуацией. Примерно такая же ситуация в угольной отрасли сложилась в северо-восточной части Якутии - Зырянском районе.

Как уже было отмечено, главной минерально-сырьевой базой угольной отрасли Дальнего Востока является Республика Саха (Якутия), суммарные запасы которой составляют порядка $36,7 \%$ по округу [1]. На эту долю приходятся высококачественные энергетические и коксующиеся угли.

Большой минерально-сырьевой потенциал имеет угольная отрасль Амурской области, на которую приходится 22,5\% [1], известно более 90 месторождений каменного и бурого угля.

В центральной и южной части Сахалинской области сосредоточено около $9 \%$ учтенных запасов ДВФО, известно более 60 месторождений. Около половины запасов углей залегает на глубине менее 300 м, но экономическую эффективность их освоения снижают горно-геологические условия их залегания и достаточно сильная тектоническая подверженность.

Хабаровский край имеет также достаточные запасы (14-15\% суммарных запасов округа) и развитую угольную базу в районах бассейна реки Бурея и чуть менее в долине реки Горин севернее Комсомольска-на-Амуре. Небольшие угольные залежи имеются и в других районах области.

Около 100 угольных месторождений и проявлений расположено в Приморском крае, это почти десятая часть территории региона и $20 \%$ округа. За исключением Синегорского и Пуциловского практически все месторождения каменных углей классифицируются как мелкие (буроугольное месторождение Бикинское является крупным, 13 средних и не менее 20 малых).

Наименьшим минерально-сырьевым потенциалом ДВФО обладают Магаданская область, Еврейская автономная область, Корякский и Чукотский автономные округа. Однако запасов местных углей здесь достаточно для полного покрытия собственных региональных потребностей при условии введения в эксплуатацию новых разведанных месторождений. Дефицитную минеральносырьевую базу для топливно-энергетической промышленности на Дальнем Востоке сегодня имеет Камчатская область. В связи с приоритетами Камчатки по развитию рыбной промышленности следует обратить особое внимание на экологическую безопасность работ при добыче, разработке и обогащении на угольных предприятиях и месторождениях.
Таким образом, все районы Дальнего Востока, Якутии в частности, имеют возможность самообеспечения отраслей региона угольной продукцией преимущественно энергетического сектора. В настоящее время предприятия работают достаточно устойчиво и при развитии региона могут увеличить производительность на 20-30\%, достигнув максимального уровня добычи и переработки. Эта производительность может быть увеличена путем замены на более производительное горнодобывающее оборудование. Инфраструктура в районах действующих предприятий достаточно развита.

Для удовлетворения потребности Камчатки необходимо произвести поиски новых месторождений угля.

В районах Магаданской области и Еврейской автономной области, а также Корякского и Чукотского автономных округов запасов местного сырья достаточно для развития местной угольной промышленности. Продолжение работ, направленных на развитие добычи в этих районах, требует капитальных затрат и совершенствования ин $\phi$ раструктуры.

С развитием угольной промышленности практически все отрасли Дальнего Востока, связанные с потреблением продукции угольного сектора, получат импульс развития. Возможности региона оцениваются высоко.

\section{Список литературы}

1. Козловский Е. А. Минерально-сырьевые ресурсы в экономике мира и России. М.: ВНИИгеосистем, 2014. 606 с.

2. Лисов В.И. Ассоциация геологических Организаций. URL: http://www. asgeos. ru/article/480.html (дата обращения 01.10.2015).

3. Платонов Н. М. Российский Дальний Восток в 19651985 годы: специфика промышленного развития. Хабаровск: ДГУПС, 2015. С. 1-12.

4. Угольная промышленность Приморья. Владивосток: Издательство ТАНЭБ, 1997. 296 с.

5. Деревянко А. П. Угольная промышленность Приморья. Страницы истории / Уголь Приморья. Материалы научно практической конференции. Владивосток: 1993. C. 20-72.

6. Статистика угольной промышленности. М.: Министерство энергетики РФ, 2015. URL: http://www. minenergo. gov. ru/activity/coalindustry (дата обращения 01.10.2015).

7. Современное состояние и перспективы развития добычи угля в период до 2030 г. в основных бассейнах и месторождениях, расположенных в Дальневосточном ФО / Л.С. Плакиткина URL: http://www. eriras. ru/files/statja_dal. vost. 25.11.2013.pdf (дата обращения 01.10.2015).

8. Кузнецова Г. А. Методология формирования социально-инновационной составляющей стратегии развития угольной промышленности Дальнего Востока:дис.... докт. техн. наук. Москва: ОАО «ЦНИЭИуголь», 2012. 284 с. 
UDC 332.1:622.33(571.6) ๔ N. Kh. Kurbanov, V.A. Rafienko, 2015

ISSN 0041-5790 (Print) • ISSN 2412-8333 (Online) • Ugol' - Russian Coal Journal, 2015, № 12, pp. 40-43

\section{Title}

DEVELOPMENT OF COAL PRODUCERS OF THE FAR EAST / DAL'NIY VOSTOK REGION/ (1965-2015)

DOI: http://dx. doi. org/10.18796/0041-5790-2015-12-40-43

\section{Authors}

Kurbanov N. Kh. ${ }^{1}$, Rafienko V. A. ${ }^{2,1}$

1 Sergo Ordzhonikidze Russian State Geological Prospecting University (MGRI-RGGRU), Moscow, 117997, Russian Federation

${ }^{2}$ Scientific-production enterprise «Filtrotkani», Moscow, 117335, Russian Federation

\section{Authors' Information}

Kurbanov N. Kh., Doctor of Economic Sciences, Professor,

Director Economical and Legal Basis of Resource Management Institute, tel.: +7 (495) 433-64-11, e-mail: epon@mgri-rggru.ru

Rafienko V. A., PhD (Engineering), PhD (Economic), General Manager,

Head of laboratory MGRI-RGGRU, tel.: +7 (495) 979-49-07,

e-mail: npp-f@yandex.ru

\section{Abstract}

The article presents an analysis of process performance of coal producers from 1965 to 2015, characterizing mainly the evolution of coal production in the Far East. It demonstrates the potential of development of coa producers in certain regions of the Far East.

\section{Keywords}

Coal Production, Coal-Mining Industry, Economical Development of the Far East, Fuel and Energy Complex of Russia, Sustainable Resource Management.

\section{References}

1. Kozlovsky E. A. Mineral'no-syr'evye resursy vekonomike mira i Rossii [Mineral Resources in the Global and Russian Economy]. Moscow, VNIlgeosystem Publ., 2014, 606 p.

2. Lisov V.I. Assotsiatsiya Geologicheskikh Organizatsiy [Association Geological Organizations]. Available at: http://www.asgeos.ru/article/480.html (accessed 01.10.2015).
3. Platonov N. M. Rossiyskiy Dal'niy Vostok v 1965-1985 gody: spetsifika promyshlennogo razvitiya [Russian Far East in 1965-1985. Particularities of the Region's Industrial Development]. Khabarovsk, DGUPS Publ., 2015, pp. 1-12.

4. Ugol'naya promyshlennost' Primor'ya. [Coal-mining Industry of the Primorye]. Vladivostok, TANEB Publ., 1997, $296 \mathrm{p}$.

5. Derevyanko A.P. Ugol'naya promyshlennost' Primor'ya. Stranitsy istorii. Ugol'Primor'ya [Coal-Mining Industry of the Primorye. Pages of History. Coal of Primorye]. Materials of the research and practice conference. Vladivostok, 1993, pp. 20-72.

6. Statistika ugol'noy promyshlennosti [Coal-Mining Industry Statistics]. Moscow: RF Ministry of Energy, 2015. Available at: http://www. minenergo.gov. ru/activity/coalindustry (accessed 01.10.2015).

7. Plakitkina L.S. Sovremennoe sostoyanie i perspektivy razvitiya dobych uglya $v$ period do 2030 goda $v$ osnovnykh basseynakh i mestorozhdeniyakh, raspolozhennykh v Dal'nevostochnom Federal'nom Okruge [Modern State and Perspective of Coal Production Development in the Period until 2030 in Main Basins and Deposits, Situated in the Far Eastern Federal District]. Available at: http://www.eriras.ru/files/statja_dal.vost.25.11.2013.pdf (accessed 01.10.2015)

8. Kuznetsova G. A. Metodologiya formirovaniya sotsial'no-innovatsionnoy sostavlyayushchey strategii razvitiya ugol'noy promyshlennosti Dal'nego Vostoka. Diss. dokt. techn. nauk [Methodology of Establishing a Social and Innovative Component of the Development Strategy of the Coal-Mining Industry Development. Dr. eng. sci. diss. ]. Moscow, JSC "TSNIElugol" Publ., $2012,284 \mathrm{p}$

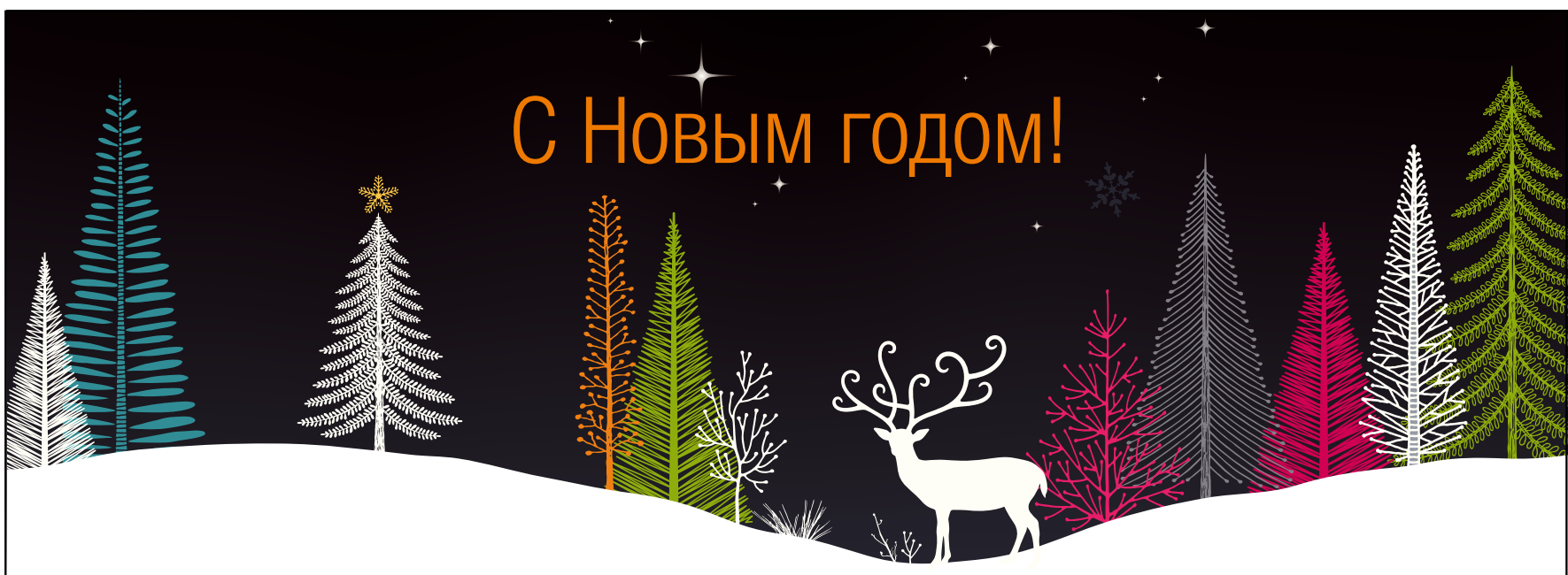

Уважаемые коллеги, партнеры и друзья

Поздравляем Вас с самым волшебным и долгожданным праздником - Новым Годом!

Желаем Вам успехов во всех делах, финансового благополучия, побольше улыбок и здоровья!

Пусть наступающий 2016 год принесет Вам много радости и положительных эмоций!

С уважением, коллектив компании БАРТЕК Зихерхайтс-Шальтаналген ГмбХ и 000 «БАРТЕК СБ»

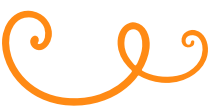




\section{Концептуальные подходы к стратегии освоения} Элегестского месторождения

\section{Улуг-Хемского угольного бассейна Республики Тыва}

DOI: http://dx. doi. org/10.18796/0041-5790-2015-12-44-46

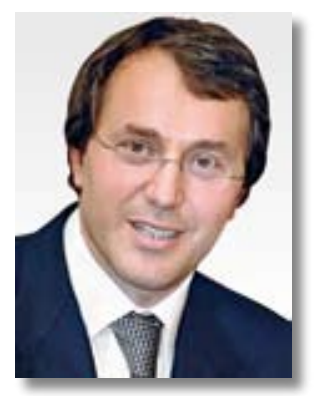

БАЙСАРОВ

Руслан Сулимович

Генеральный директор

ЗАО «Тувинская Энергетическая

Промышленная Корпорация» (ТЭПК),

667000, г. Кызыл,

Республика Тыва, Россия

тел.: +7 (495) 514-15-57,

e-mail: tepk@tepk-invest.ru

Предложены концептуальные подходы к освоению Элегестского месторождения каменного угля Улуг-Хемского угольного бассейна в Республике Тыва на основе реализации крупного инфраструктурного проекта $3 A O$ «Тувинская Энергетическая Промышленная Корпорация» (ТПК) - «Строительство железной дороги Элегест - Кызыл - Курагино и угольного портового терминала на Дальнем Востоке в увязке с освоением минерально-сырьевой базы Республики Тыва».

Ключевыеслова:концептуальныеподходы, инфраструктурный проект, лицензионный участок, государственночастное партнерство, транспортная логистика.

Элегестское месторождение каменного угля находится в западной части Улуг-Хемского угольного бассейна Республики Тыва. Общая площадь бассейна составляет порядка 2300 кв. км, площадь Элегестского месторождения - около 83 кв. км. Месторождение расположено на лево - и правобережье нижнего течения р. Элегест, левого притока р. Верхний Енисей в наиболее экономически освоенной центральной части республики, в 30 км от ее столицы г. Кызыла (рис. 1).

В административном отношении северная часть месторождения расположена на территории Кызылского кожууна, южная - на территории Тандинского кожууна. Непосредственно на площади Элегестского месторождения населенных пунктов нет, а в устьевой части р. Элегест находится с. Усть-Элегест с населением до 2000 человек.

Поверхность Элегестского месторождения представляет собой всхолмленную равнину с абсолютными отметками 600-900 м. Относительные превышения - до 100 м, крутизна склонов - 5-10 , редко до $30^{\circ}$.

В 2006-2009 гг. была проведена детальная разведка Элегестского месторождения каменного угля.

С апреля 2013 г. право пользования недрами с целью разведки и добычи каменного угля на лицензионном участке Элегестского месторождения, удостоверенное лицензией
КЗЛ 15564 ТЭ, было предоставлено ООО «Тувинская Энергетическая Промышленная Корпорация» (ООО «ТЭПК») какпобедителю конкурса на право пользования участками недрс последующим переоформлением на ЗАО «ТЭПК» (лицензия КЗЛ 00469 ТЭ от 29.08.2014 сроком до 20.05.2033).

В результате проведенных геологоразведочных работ на лицензионном участке подсчитаны запасы коксующихся углей марки Ж по шести угольным пластам по категориям $\mathrm{A}+\mathrm{B}+\mathrm{C}_{1}+\mathrm{C}_{2}$ в объеме 855089 тыс. т, из них запасы для разработки подземным способом составляют по категории $A+B+C_{1}+C_{2} 837327$ тыс. т, а для разработки открытым способом - 15100 тыс. т [1].

Угольные пласты Элегестского месторождения по мощности относятся к мощным, средней мощности, тонким и весьма тонким. По сложности строения они относятся к пластам преимущественно простого строения, реже сложного, по степени выдержанности - к выдержанным, относительно выдержанным и невыдержанным. По углам залегания относятся к пологозалегающим (до $18^{\circ}$ ) и наклонным (19-35) пластам.

Республика Тыва до сих пор не имеет связи с железнодорожной сетью страны и транспорт, обеспечивающий экономические связи как внутри Тывы, так и с другими регионами, представлен автомобильным, внутренним водным (речным) и авиационным видами. Еще в 2000-е годы возник проект строительства первой в республике железной дороги по маршруту от г. Кызыла до железнодорожной станции Курагино на юге Красноярского края, основной целью которого являлся вывоз каменного угля с Улуг-Хемского месторождения, а также приближение ее к месторождениям железной руды в Красноярском крае. Строительство планировалось начать в 2009 г., но в связи с финансово-экономическим кризисом в России основные объемы финансирования были перенесены на 2012 г., однако в течение всего года велись лишь разработка рабочей документации и изыскания на маршруте будущей железной дороги.

Возможность реального воплощения в жизнь этот проект получил только в последние годы, когда его инициатором, инвестором и ответственным исполнителем выступило 3 АО «ТЭПК». Предприятием предложена концепция единого комплексного инфраструктурного проекта освоения минерально-сырьевой базы Республики Тыва в части освоения Элегестского месторождения и одновременного развития мультимодальной логистики транспортировки угля на экспорт по железной дороге Элегест - Кызыл - Курагино с выходом через Транссиб и БАМ до порта Ванино с последующей транспортировкой морем в страны АзиатскоТихоокеаского региона (АТР) [1] (рис. 2). 
При реализации инфраструктурного проекта «Строительство железной дороги Элегест - Кызыл - Курагино и угольного портового терминала на Дальнем Востоке в увязке с освоением минерально-сырьевой базы Республики Тыва» приняты следующие концептуальные подходы к стратегии освоения Элегестского месторождения Улуг-Хемского угольного бассейна:

- данный инвестиционный инфраструктурный проект следует рассматривать как межрегиональную производственно-логистическую систему, реализуемую на принципах государственно-частного партнерства и состоящую из трех взаимосвязанных звеньев (подпроектов):

- строительство горно-обогатительного комплекса «Элегест» производственной мощностью 15 млн т концентрата коксующегося угля в год в Республике Тыва, включая вахтовый поселок;

- строительство железной дороги Элегест - Кызыл - Курагино на территориях Республики Тыва и Красноярского края протяженностью 410 км с плановой пропускной способностью 15 млн т угля и 3 млн т народнохозяйственных грузов в год;

- строительство глубоководного морского терминала мощностью по перевалке 15 млн т угля в год в районе мыса Бурный (порт Ванино в Хабаровском крае);

- в основе стратегии прежде всего должна лежать научно обоснованная концепция развития всей минерально-сырьевой базы Республики Тыва, определяющая не только основные направления воспроизводства ресурсов и технологического развития, но и программирование социально-эконо-

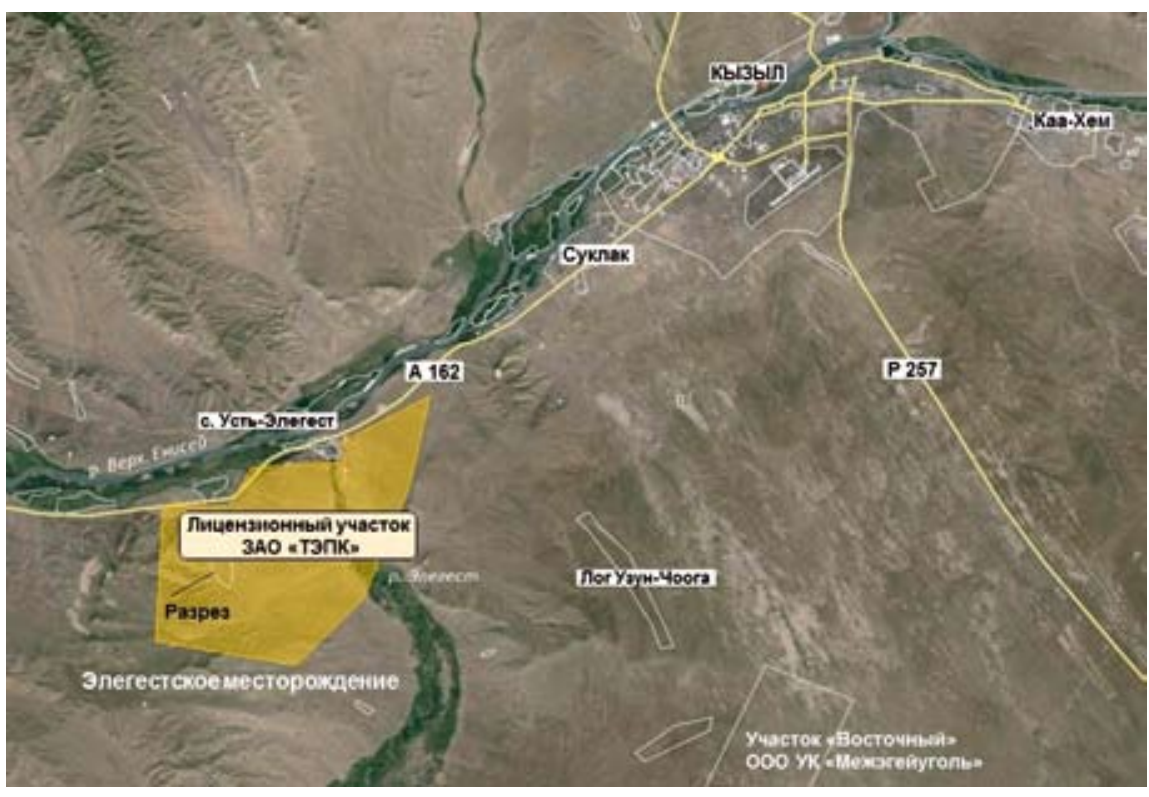

Рис. 1. Ситуационный план расположения лицензионного участка 3 АО «ТЭПК» на Элегестском месторождении Улуг-Хемского угольного бассейна

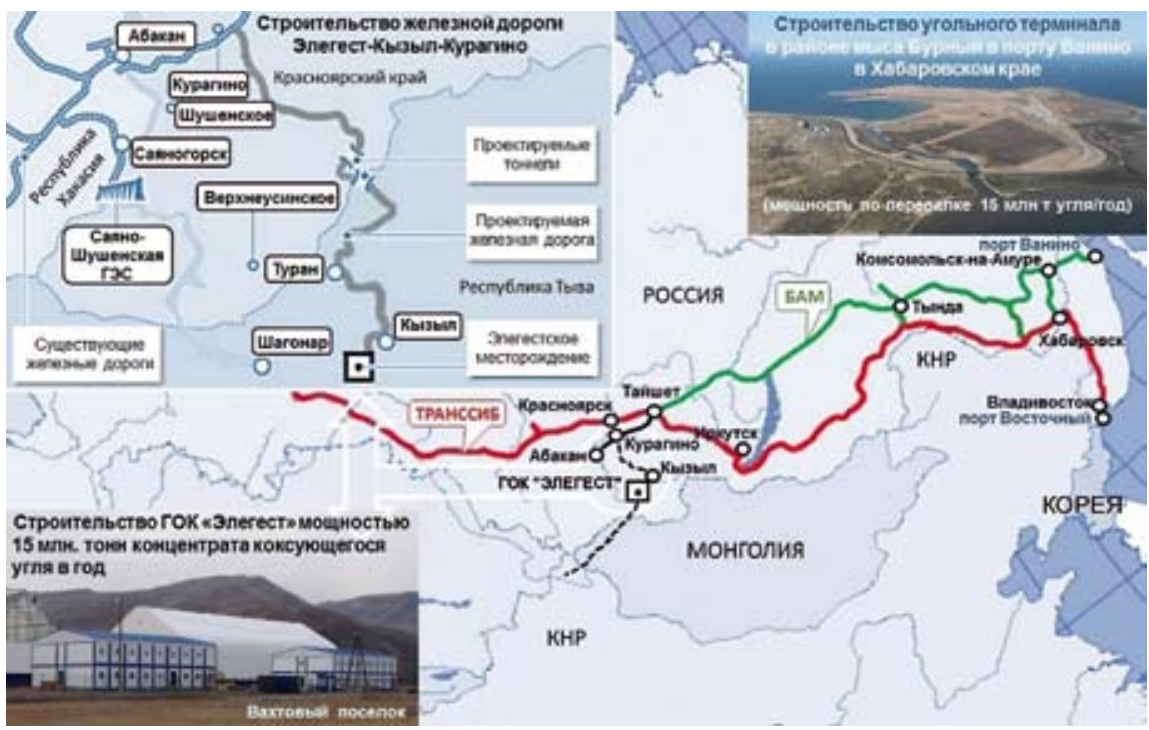

Puс. 2. Карта-схема расположения объектов инфраструктурного проекта «Строительство железной дороги Элегест - Кызыл - Курагино и угольного портового терминала на Дальнем Востоке в увязке с освоением минерально-сырьевой базы Республики Тыва» мического развития региона. При этом темпы и масштабы освоения минеральных ресурсов в экономике региона должны определяться с позиций бюджетных, коммерческих и общественных эффектов, в основе которых лежат социальные и экологические результаты деятельности предприятий горнопромышленного комплекса;

- освоение Элегестского месторождения на всех его этапах, нацеленное на повышение рентабельности угольного производства, должно быть также социально ориентированным при условии своевременного обеспечения достойной социальной поддержки всех слоев населения углепромышленных территорий, интересы которых негативно затрагиваются в процессе недропользования в форме его социально-экономических и экологических последствий;

- стратегия освоения Элегестского месторождения в части реализации угольных и транспортных проектов должна опираться на комплексный подход к решению межрегиональных проблем и гармонично встраиваться в стратегические программы социально-экономического развития Республики Тыва, Красноярского и Хабаровского краев, а также в федеральные целевые программы на принципах государственно-частного партнерства;

- строительство железной дороги Элегест — Кызыл Курагино и угольного портового терминала на Дальнем Востоке должны стать важными звеньями в стратегическом развитии интермодального транспортного общеевропейского коридора «Запад - Восток» («Транссиб») транзитных российских перевозок, включая мультимодальную доставку угля в страны АTP;

- стратегические перспективы освоения Элегестского месторождения и минерально-сырьевой базы Тывы в целом в сфере железнодорожной транспортной логистики должны быть связаны со строительством Тувинско-Монгольской железной дороги через Западную Монголию в Северо-Западный Китай в увязке с разработкой попут- 
ных месторождений полезных ископаемых. Транзит через Туву позволит сократить перевозки в Монголию и Китай на 1,5-2 тыс. км, что будет иметь немаловажное значение для логистической стратегии развития российской экономики в целом;

- стратегия освоения Элегестского месторождения должна сформировать научно-обоснованные методические подходы к стратегическому программированию социально-экономического территориального развития при реализации крупных межрегиональных инвестиционных инфраструктурных проектов на принципах государственно-частного партнерства, обеспечить внедрение инноваций в рациональное недропользование и обосновать выбор наиболее оптимального использования сырьевых активов, а также обеспечить эффективное и устойчивое развитие ряда смежных проектов в базовых отраслях промышленности Республики Тыва и модернизации транспортной инфраструктуры.

Предложенные концептуальные подходы к стратегии освоения Элегестского месторождения легли в основу разработки паспорта инвестиционного проекта «Строительство железной дороги Элегест - Кызыл - Курагино и угольного портового терминала на Дальнем Востоке в увязке с освоением минерально-сырьевой базы Республики Тыва», утвержденного распоряжением Правительства Российской Федерации от 16 июня 2014 г. № 1059-р [2].

С учетом этих подходов ООО «Сибгеопроект» (г. Кемерово) был также разработан рабочий проект горно-обогатительного комплекса «Элегест» на Элегестском месторождении, получивший положительное заключение Главгосэкспертизы России в мае 2015 г. [3].

С учетом изложенных основных концептуальных подходов к стратегии освоения Элегестского месторождения Улуг-Хемского угольного бассейна актуальной первооче- редной научной задачей является разработка организационно-экономического механизма производственно-логистической системы его комплексного освоения, основанной на принципах государственно-частного партнерства и позволяющего сбалансировать и скоординировать действия всех участников (операторов) этого процесса на уровне федеральныхи региональныхорганов государственнойвласти, отраслевых организаций в области добычи и обогащения угля, а также транспортной логистики угольных потоков с учетом требований социальной, экологической и энергетической безопасности каждой конкретной территории.

\section{Список литературы}

1. Байсаров Р.С. Комплексное освоение Элегестского месторождения коксующегося угля на основе государственно-частного партнерства / Антикризисное управление: производственные и территориальные аспекты: сб. ст. / под общ. ред. И.Г.Степанова, Д.Г. Вержицкого; Министерство образования и науки Российской Федерации; Новокузнецкий институт (филиал) Кемеровского государственного университета. Новокузнецк: НФИ КемГУ, 2015. С. 7-17.

2. Распоряжение Правительства Российской Федерации от 16 июня 2014 г. № 1059-р «О внесении изменений в распоряжение Правительства РФ от 05.11.2013 № 2044-р и утверждении паспортов инвестиционных проектов». [Электронный ресурс]. Режим доступа: http://www.garant. ru/products/ipo/prime/doc/70580440/.

3. Горно-обогатительный комплекс «Элегест» на Элегестском месторождении Улуг-Хемского угольного бассейна Республики Тыва производственной мощностью 15 млн. т концентрата коксующегося угля в год. - Проектная документация. Раздел 1. Пояснительная записка. Часть 1 - Общая пояснительная записка 1 - 2014/П-Г/1-П31. Том 1.1. Кемерово: ООО «Сибгеопроект». 86 с.

UDC 332.1:622.33(571.52) @ R.S. Baysarov, 2015

ISSN 0041-5790 (Print) • ISSN 2412-8333 (Online) • Ugol' — Russian Coal Journal, 2015, № 12, pp. 44-46

Title

THE CONCEPTUAL APPROACHES TO THE ELEGESTSKY FIELD OF ULUGH-KHEM COAL BASIN IN THE REPUBLIC OF TYVA DEVELOPMENT STRATEGY

DOI: http://dx.doi.org/10.18796/0041-5790-2015-12-44-46

Author

Baysarov R.S.'

${ }^{1}$ Tuva Energy Industrial Corporation CJSC (TEIC), Kyzyl, 667000, the Republic of Tyva, Russian Federation

Authors' Information

Baysarov R.S, General Director, tel.: +7 (495) 514-15-57,

e-mail: tepk@tepk-invest.ru

\section{Abstract}

The conceptual approaches to the Elegestsky coalfield of Ulugh-Khem coal basin in the Republic of Tyva development based on the implementation of major infrastructural project of Tuva Energy Industrial Corporation CJSC (TEIC) - "The Elegest-Kyzyl-Kuragino rail road and coal port terminal construction in the Far East in the context of mineral resources base of the Republic of Tyva development".

\section{Keywords}

Conceptual approaches, infrastructural project, license area, public-private partnership, transportation logistics.

\section{References}

1. Baysarov R.S. Kompleksnoe osvoyenie Elegestskogo mestorozhdeniya koksyuschegosya uglya na osnove gosudarstvenno-chastnogo partnerstva [Integrated Elegestsky metallurgical coal field development on the basis of public-private partnership]. Anti-crisis management: industrial and territorial aspects: Col- lection of articles under the general editorship of Stepanov I.G., Verzhitskiy. Ministry of Education and Science of the Russian Federation, Novokuznetsk Institute (branch) of Kemerovo State University. Novokuznetsk, NFI KemGU Publ., 2015, pp. 7-17.

2. Rasporyazhenie Pravitelstva Rossiyskoy Federatsii ot 16 iyunya $2014 \mathrm{~g}$ no. 1059-r "O vnesenii izmeneniy v Rasporyazhenie Pravitelstva RF ot 05.11.2013 no. 2044-r i utverzhdenii passportov investitsionnykh proektov" [Regulation of Russian Federation Government no. 1059-r of June 16, 2014 "On the amendments in the regulation of RF Government no. 2044-r of 05.11.2013 and investment projects certificates approval procedure"]. Available at: URL: http://www.garant.ru/products/ipo/prime/doc/70580440/. 3. Gorno-obogatitel'nyy kompleks "Elegest" na Elegestskom mestorozhdenii UlugKhemskogo ugol'nogo basseyna Respubliki Tyva proizvodstvennoymoshchnost'yu $15 \mathrm{mln}$. $t$ kontsentrata koksuyushchegosya uglya $v$ god ["Elegest" mining and processing complex in the Elegestsky coalfield of Ulugh-Khem coal basin in the Republic of Tyva with production capacity of $15 \mathrm{mln}$. $t$ of metallurgical coal concentrate]. Proektnaya dokumentatsiya. Razdel 1. Poyasnitel'naya zapiska. Chast' 1: Obshchaya poyasnitel'naya zapiska 1-2014/P-G/1-PZ1 [Design documentation, Chapter 1, Explanatory note, Part 1: General explanatory note 1-2014/P-G/1-PZ1. Vol. 1.1. Kemerovo, "Sibgeoproekt" Publ., 86 p. 


\section{Шахта «Имени 7 Ноября» встретила свой юбилей досрочным выполнением производственных планов}

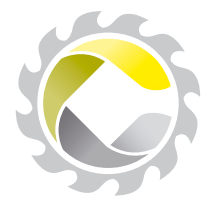

32

СИБИРСКАЯ УГОЛЬНАЯ ЭНЕРГЕТИЧЕСКАЯ КОМПАНИЯ

\section{5-летний юбилей торжественно отметил коллектив Шахты «Имени 7 Ноября» (г. Ленинск-Кузнецкий), входящей в состав компании «СУЭК-Кузбасс»。}

Это первое угледобывающее предприятие Кольчугинского рудника, сооруженное в советское время. В ноябре 1930 г. была принята в эксплуатацию шахта «Байкаимская». Спустя ровно год по решению коллектива она названа именем 7 Ноября.

За свою историю предприятие не раз достигало выдающихся производственных результатов. В 1960-1970-е годы очистные бригады Дмитрия Придаченко и Алексея Попова были в числе лидеров угольной отрасли страны по уровню производительности труда на механизированных комплексах. Оба бригадира удостоены высокого звания Герой Социалистического Труда. В 1980-е годы на шахте одной из первых в Кузбассе появились бригады«миллионеры». За наивысшие показатели в выполнении планов пятилетки и проявленную трудовую доблесть коллектив шахты награжден орденом Трудового Красного Знамени.

Новый виток в развитии начался с вхождения предприятия в 2003 г. в состав Сибирской угольной энергетической компании. Совет директоров компании под руководством Андрея Мельниченко принял решение модернизировать предприятие до стандартов мирового уровня. Для технического перевооружения было приобретено самое современное оборудование. Только за последние четыре года в шахту инвестировано почти 2 млрд руб., из них более 200 млн руб. - непосредственно в программы безопасности.

Сегодня Шахта «Имени 7 Ноября» по уровню производительности входит в число лидеров мировой угольной отрасли. Добываемый уголь отличается высоким качеством и практически полностью отгружается на экспорт. Закономерным результатом грамотной технической и кадровой политики стало установление 10 декабря 2014 г. бригадой Героя Кузбасса Василия Ватокина нового российского рекорда добычи за год из одного очистного забоя 4 млн 661 тыс. т.

В 2015 г. этот же очистной коллектив первым в отрасли добыл двухмиллионную тонну угля. В честь празднования Великой Победы силами Шахты «Имени 7 Ноября» совместно с областными и городскими властями сооружен мемориальный сквер. А к своему юбилею предприятие досрочно выполнило производственные планы как по добыче, так и по проходке.

В рамках торжественных юбилейных мероприятий большая группа горняков Шахты «Имени 7 Ноября» была награждена ведомственными, областными, городскими и корпоративными наградами. Памятные подарки вручены ветеранам предприятия. Наградой для всего коллектива стал сертификат от компании на один миллион рублей.
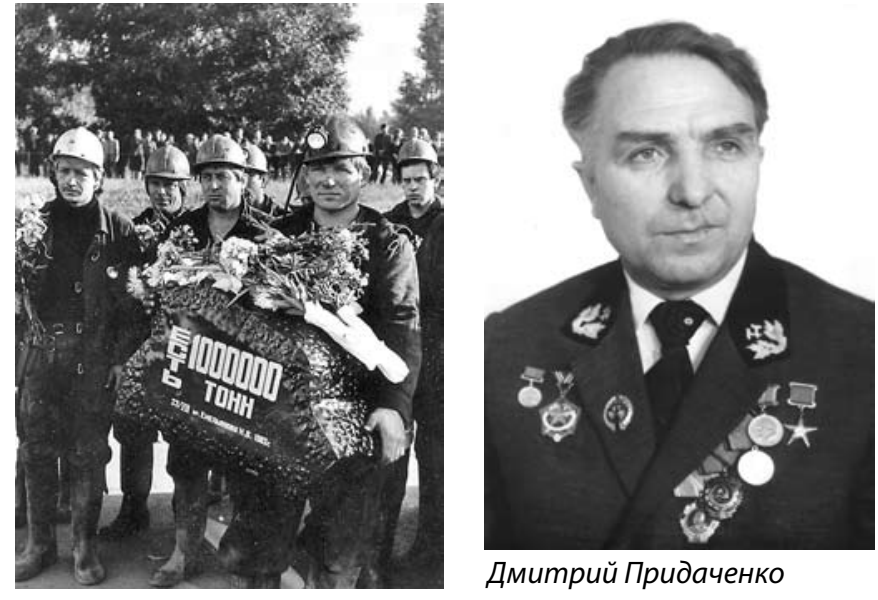

Дмитрий Придаченко

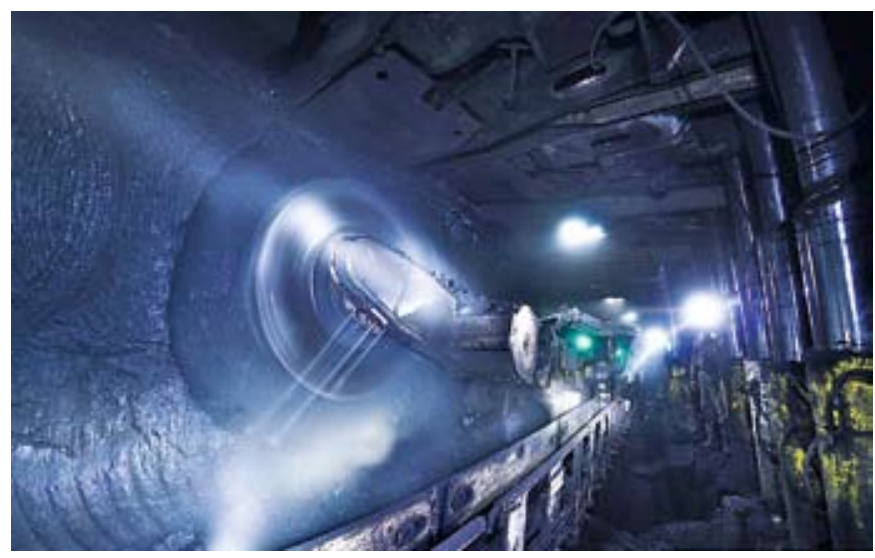

С юбилеем коллектив предприятия поздравил губернатор Кемеровской области Аман Тулеев: «Благодаря вашим ярким профессиональным подвигам складывается шахтерская история Земли Кузнецкой, сохраняется и преумножается бесценный опыт лучших достижений наших шахтеров. И сегодня Шахта «Имени 7 Ноября» является рекордсменом угольной отрасли России. Спасибовам за созидательный труд, упорство, глубокое понимание своего профессионального долга», - говорится в поздравительной телеграмме.

Генеральный директор ОАО «СУЭК» Владимир Рашевский отметил: «Сегодня славные традиции предприятия получают новое развитие. Эстафету своих отцов достойно перенимают новые поколения шахтеров. Это челеустремленные профессионалы, трудолюбивые, полные инициативы и созидательной энергии, каждый из которых вносит большой вклад в наше общее дело. Нет сомнений в том, что удружного коллектива Шахты «Имени 7 Ноября» впереди еще очень много выдающихся и славных побед, которые золотыми буквами будут вписаны в будущую историю предприятия и всей угольной отрасли страны!» 


\section{В Разрезоуправлении «Новошахтинское» ОАО «Приморскуголь» введен в эксплуатацию новый экскаватор НІТАСНI}

В РУ «Новошахтинское» приступил к работе электрогидравлический экскаватор HITACHI EX 2600 №8 с вместимостью ковша 15 куб. м с рабочим оборудованием «прямая лопата». Новая единица техники
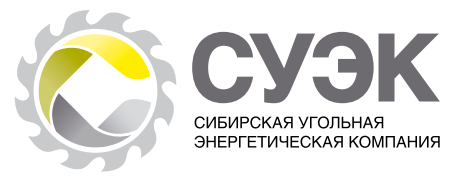

Перед экипажем нового HITACHI EX 2600 №8 поставлена задача достичь уровня переработки горной массы в объеме 600 тыс. куб.м в месяц.

Разрезоуправление «Новошахтинспоступила по инвестиционной программе СУЭК, направленной на модернизацию оборудования и перспективное развитие предприятия. В рамкахэтой программы производится замена экскаваторов с мехлопатой на гидравлические экскаваторы, увеличивается парк большегрузных машин, внедрена конвейерная технология доставки угля из забоя на пункты отгрузки угля. Первые два гидравлических экскватора высокой производительности (НITACHI EX 2500, «обратная лопата») поступили на разрез в 2010-2012 гг. Достигнутая месячная производительность каждой машины составила более 500 тыс. куб.м вскрыши. Внедрение новых технических мощностей позволило предприятию в 2011 г. выйти на максимальный уровень добычи 4,5 млн т угля в год. кое» - самое крупное предприятие ОАО «Приморскуголь» - годовой план по добыче и отгрузке угля выполнило уже в августе 2015 г. В первом квартале 2015 г. коллектив разрезоуправления установил производственный рекорд, впервые в истории предприятия преодолев 1,5-миллионный уровень добычи и отгрузки угля.

Как ранее отмечал в интервью журналу «Эксперт» основной владелец АО «СУЭК» Андрей Мельниченко, «компания активно развивает добычу и обогащение угля на Дальнем Востоке и в Восточной Сибири, что позволяет опережающими темпами наращивать сбыт на приоритетных азиатских рынках. Одновременно идут инвестиции в оптимизацию стоимости доставки продукта к потребителю».

\section{Бородинский ремонтно-механический завод освоил выпуск инновационных двигателей для БелАЗов}

ООО «Бородинский ремонтно-механический завод» (БРМЗ), сервисное предприятие Сибирской угольной энергетической компании, освоило выпуск инновационных двигателей для автомобилей БелАЗ.

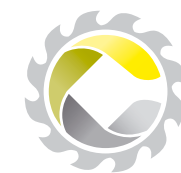

Новые вентильно-индукторные двигатели представляют собой сложную комплексную систему, сочетающую свойства нескольких различных видов преобразователей энергии. Такие устройства обладают высокой динамикой, отличаются надежностью и износостойкостью. Благодаря тому, что в них отсутствуют движущие части, использование вентильно-индукторных двигателей возможно во взрывоопасной агрессивной среде.

Подобными двигателями, произведенными на БРМЗ, уже оснащено несколько участков уникального ленточного конвейера, связывающего Березовский разрез и Березовскую ГРЭС в г. Шарыпово. Теперь специалисты завода адаптировали вентильно-индукторные устройства к использованию их на большегрузах БелАЗ.

«Проект реализуется совместно с разработчиками данного двигателя, - поясняет исполнительный директор ООО «Бородинский РМЗ» Сергей Козубов, - это их ноу-хау. Двигатель обладает улучшенными тяговымихарактеристиками. Экономическийэффектот егоустанов-

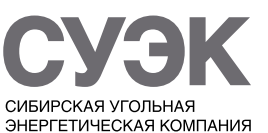

ки - этоувеличение скорости перевозок и сокращение затрат на ГСМ. Это принципиально новый вид продукции, двигателитакого принципа действия в России и за рубежом еще не производились».

«Приизготовлениидвигателейунасзадействованы все цехазавода - механический, литейный, горный, электроремонтный, плазменной резки, - рассказывает технолог ООО «Бородинский РМЗ» Анастасия Куницина. - Только катушки к нам приходили готовые, все остальное, вплоть до болтов, изготовлено и собрано на заводе. Работа проделана очень маситабная».

Два вентильно-индукторных двигателя для БелАЗов уже готовы и ждут отправки в Бурятию, на Тугнуйский разрез, также входящий в состав СУЭК. Еще два экземпляра бородинцы должны изготовить до конца года.

\section{Наша справка.}

АО «СУЭК» —однаиз ведущихугледобывающихкомпаний мира, крупнейщий в России производитель угля, крупнейший поставщик на внутренний рынок и на экспорт. Добывающие, перерабатывающие, транспортные и сервисные предприятия СУЭК расположены в семи регионах России. На предприятиях СУЭК работают более 33 тыс. человек. Основной акционер - Андрей Мельниченко (92,2%). 


\section{Организационные и технологические}

\section{решения по обеспечению \\ жизнеспособности разреза «Изыхский»}

DOI: http://dx. doi. org/10.18796/0041-5790-2015-12-49-51

В статье представлены условия, обусловившие обострение необходимости повышения инвестиционной привлекательности разреза. Приведены мероприятия по повышению жизнеспособности разреза и результаты их реализации.

Ключевые слова: жизнеспособность, инвестичионная привлекательность, разрез, организация, технология, решения по обеспечению.

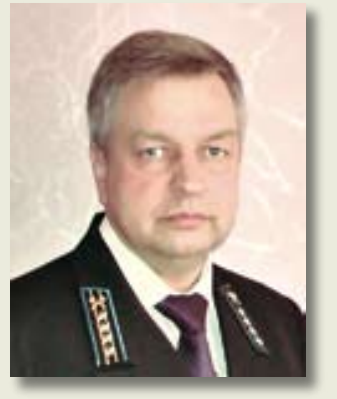

\section{ОШАРОВ}

Алексей Владимирович Исполнительный директор ОАО «Разрез Изыхский», 655650, с. Белый Яр, Республика Хакасия, Россия, тел.: +7 (39041) 2-92-00
В условиях ужесточающейся конкуренции на рынке угля для разреза «Изыхский» задача обеспечения инвестиционной привлекательности, оцениваемой по матрице

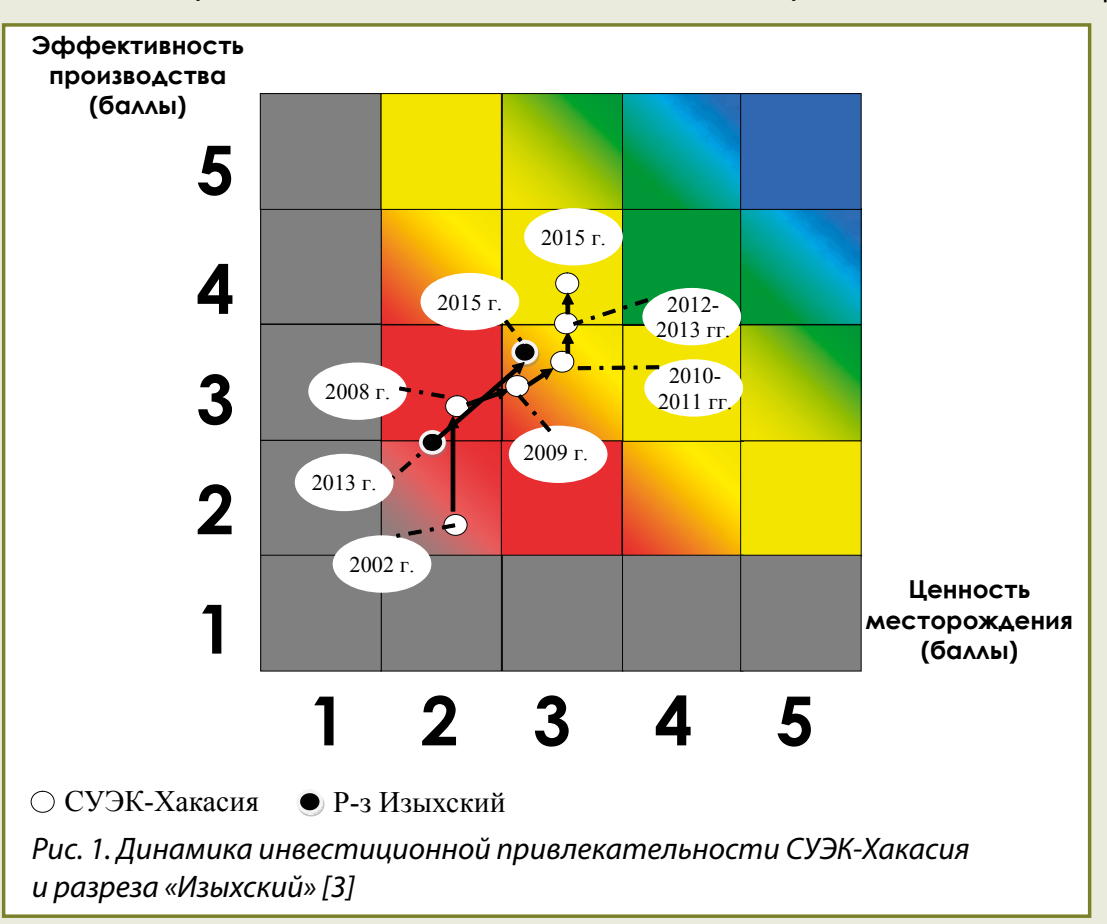

В.Б. Артемьева [1], — как одного из основных показателей жизнеспособности, обостряется ввиду относительно невысокой ценности разрабатываемого месторождения (рис. 1, см. таблицу).

Объемы реализации угля начиная с 2005 r. характеризуются нестабильностью на фоне устойчивого роста добычи и реализации угля как в СУЭКе в целом, так и в СУЭК-Хакасии (рис. 2).

В 2013 г. спрос на угольную продукцию разреза «Изыхский» стал настолько мал, что разрез стал убыточным и, соответственно, появилась необходимость найти путь сохранения его жизнеспособности.

Управляемым фактором, влияющим на ценность конкретного месторождения $\left(\bigsqcup_{M}\right)$, согласно формуле (1), является коэффициент вскрыши, который можно изменить на основе изменения технологии отработки.

$$
\bigsqcup_{M}=F\left(K y, 3 y, k_{\text {вскр }}, \Gamma p\right) \text {, [2] }
$$

где: $K y-$ качество угля; $3 y-$ запасы угля; $k_{\text {вскр }}$ - коэффициент вскрыши; Гр - география региона.

\section{Оценочная шкала инвестиционной привлекательности угледобывающего предприятия [1]}

\begin{tabular}{|c|c|c|}
\hline Балл & $\begin{array}{c}\text { Ценность } \\
\text { месторождения }\end{array}$ & эффективность производства \\
\hline $\mathbf{5}$ & Очень высокая & Рекордная («лидерская») \\
\hline $\mathbf{4}$ & Высокая & Высокая \\
\hline $\mathbf{3}$ & Средняя & Средняя \\
\hline $\mathbf{2}$ & Низкая & Низкая \\
\hline $\mathbf{1}$ & Очень низкая & Очень низкая \\
\hline
\end{tabular}

Инвестиционная привлекательность предприятия

Чрезвычайно высокая

Очень высокая

Средняя

Очень низкая

Непривлекательное 


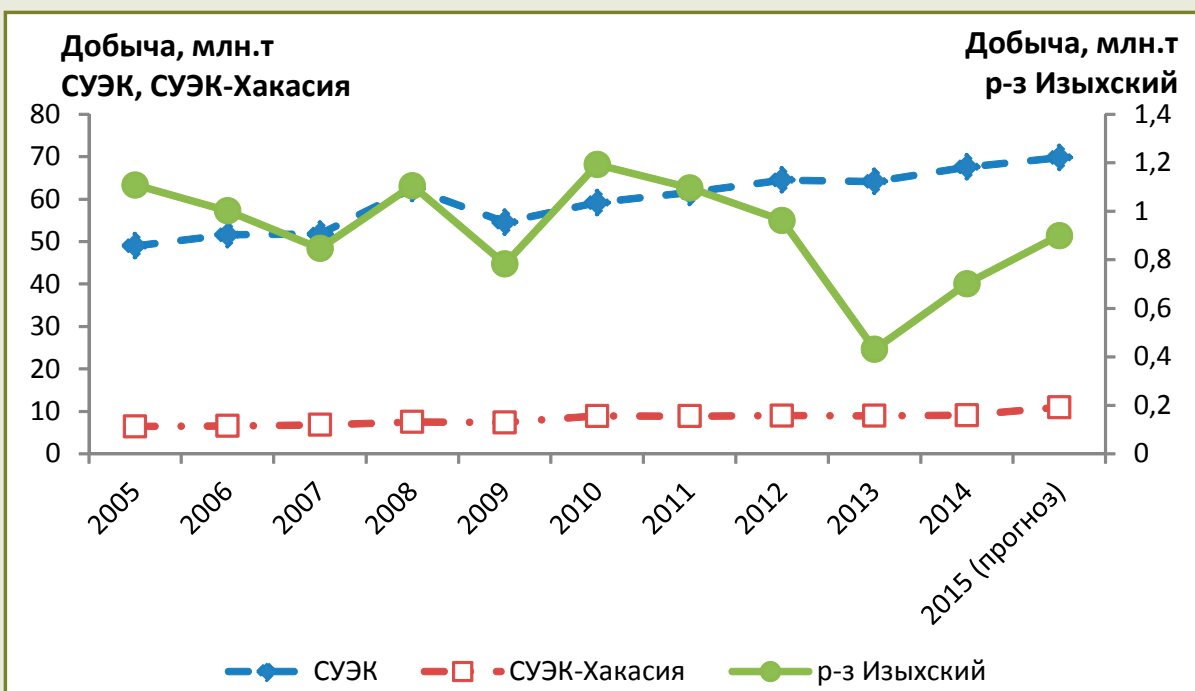

Puс. 2. Объем добычи угля открытым способом в 2005-2015 г2.

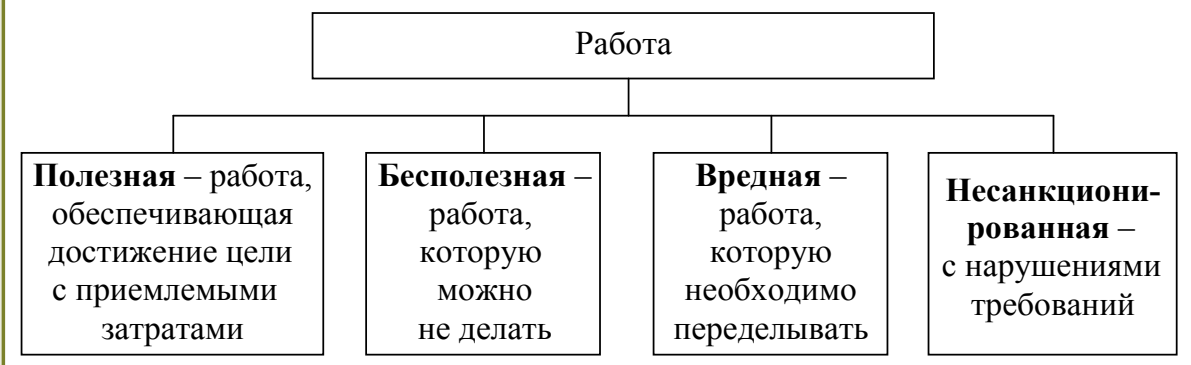

Puс. 3. Виды работы

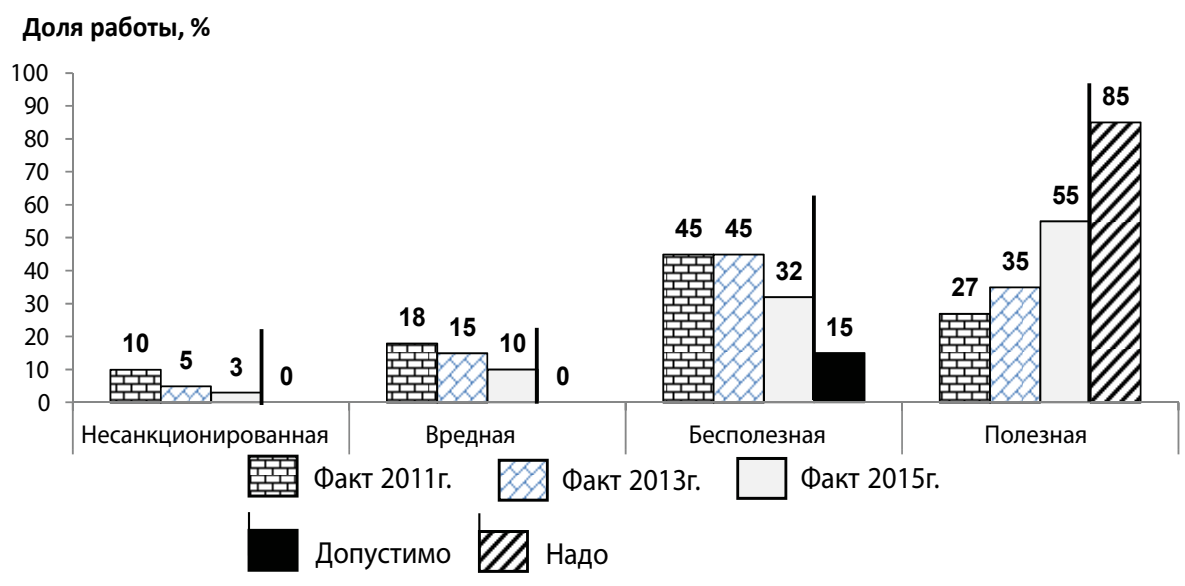

Puс. 4. Структура работы на примере разреза «Изыхский»

На эффективность производства (Э ) влияют безопасность, технология и организация производства:

$$
\ni_{\Pi}=f\left(Б_{\Pi}, T_{\Pi}, O_{\Pi}\right),[2]
$$

где: $5_{\Pi}-$ безопасность производства; $T_{\Pi}$ - технология производства; $O_{\Pi}$ - организация производства.

Анализ сложившейся ситуации позволил найти необходимые технологические и организационные решения с целью сокращения издержек производства. На их основе выработана программа антикризисных мер, включающая в части технологии следующее:

- ликвидирована железнодорожная вскрыша;

- временно приостановлена автомобильная вскрыша;

- определены участки месторождения, на которых была возможна подготовка запасов угля по бестранспортной вскрыше, что позволило снизить коэффициент вскрыши по разрезу с 5,1 до 2,6;

- основное горнотранспортное оборудование было частично законсервировано (два экскаватора ЭКГ-8И, один экскаватор ЭШ 10/70, один экскаватор ЭШ 13/50, три локомотива ТЭМ-7, три единицы вспомогательной железнодорожной техники), а частично передано на разрез «Черногорский» (один экскаватор РС-1250, один погрузчик WA-900, три автосамосвала БелАЗ75131).

\section{В части организации:}

- на внутрифирменный аутсорсинг передан погрузочно-транспортный цех (два локомотива ТЭМ-7, три единицы вспомогательной железнодорожной техники, 34 км железнодорожных путей);

- осуществлены: частичная передача персонала на профильные предприятия компании АО «СУЭК», а также сокращение штата с выплатой предусмотренного законом выходного пособия на основе составленных в 2014 г. мероприятий по оптимизации численности;

- минимизированы затраты на материальные ресурсы.

Выполненные мероприятия позволили снизить себестоимость 1 т угля более чем в два раза.

При оптимизации численности персонала было необходимо изменение организации производства. Показателями качества организации производственных процессов являются: структура рабочего времени персонала, структура выполняемой им работы и доля производительного времени труда персонала и работы оборудования. С этой целью автором начато исследование структуры рабочего времени работы персонала по критерию полезности [4]. Структура рабочего времени - это соотношение затрат времени работника на выполнение работ.

Анализ деятельности персонала показал, что в совершаемой им работе можно выделить четыре вида, которым соответствует определенная структура рабочего времени (рuс. 3).

Вид выполняемой работы обусловливает расход ресурсов и, соответственно, эффективность производства.

Изменение структуры рабочего времени персонала разреза, достигнутое на основе реализации разработанных 


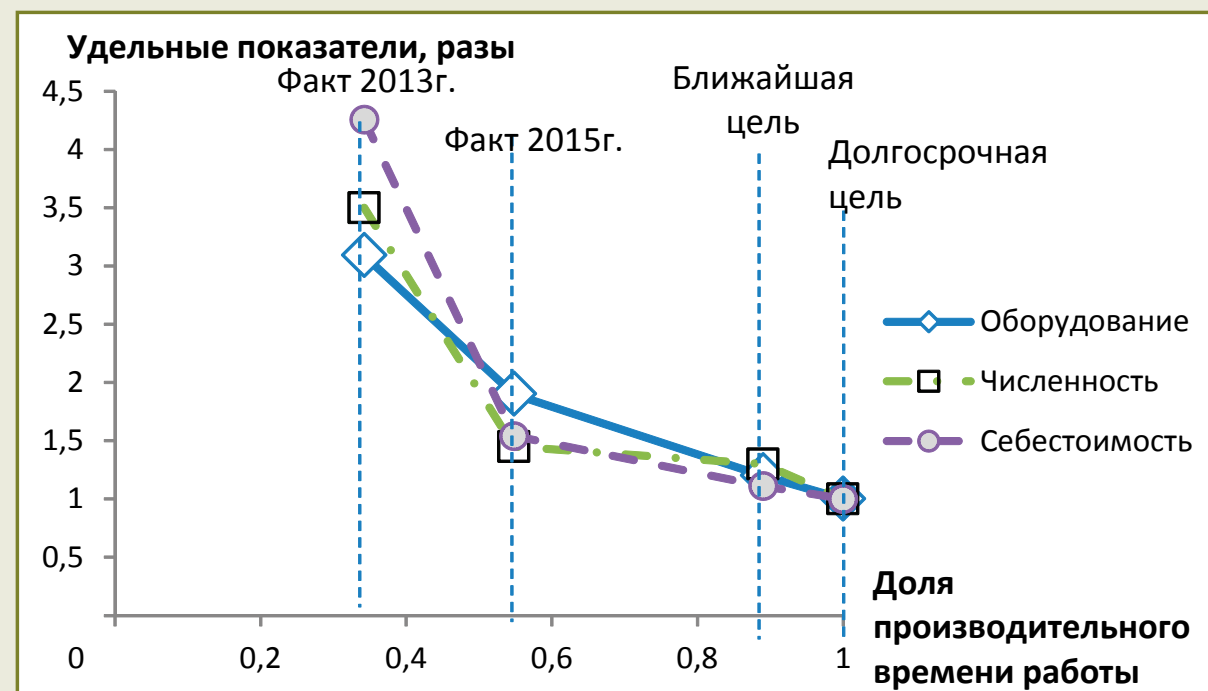

Pис. 5. Основные показатели разреза «Изыхский» в 2013-2015 22. со структурой работы, а также с результатами функционирования разреза.

\section{Список литературы}

1. Артемьев В.Б. Стратегия организационно-технологического развития угледобычи в ОАО «СУЭК» // Уголь. 2008. Спецвыпуск. С. 11.

2. Галкин В.А. Созидательный и разрушительный потенциал организации производства // Горный информационно-аналитический бюллетень (научно-технический журнал). 2015. №10. Спец. выпуск №45.

3. Килин А.Б., Костарев А.С., Полещук М.Н. Роль конкордации в инвестиционной деятельности организационных и технологических решений, представлено на рис. 4.

Динамика показателей по результатам изменений, проведенных в этот период, а также целевые значения представлены на рис. 5.

Между структурой работы и структурой рабочего времени персонала есть связь, установление и применение которой позволит управлять рабочим временем персонала для повышения безопасности и эффективности производства. Поэтому в качестве следующего шага необходимо установление связи структуры рабочего времени угледобывающих предприятий ООО «СУЭК-Хакасия» // Организация и управление горным предприятием: Отдельный выпуск Горного информационно-аналитического бюллетеня (научно-технического журнала). 2014. № OB5. C. 48-59.

4. Ошаров А. В., Захаров С.И. Анализ структуры рабочего времени руководителей на угольном разрезе // Организация и управление горным предприятием: Отдельный выпуск Горного информационно-аналитического бюллетеня (научно-технического журнала. 2014. № OB5. С. 159-167.

UDC 658.5:622.33.012.3"Izykhskiy" @ A.V. Osharov, 2015

PRODUCTION SETAP

ISSN 0041-5790 (Print) • ISSN 2412-8333 (Online) • Ugol' — Russian Coal Journal, 2015, № 12, pp. 49-51

\section{Title}

ORGANIZATIONAL AND TECHNOLOGICAL SOLUTIONS FOR “IZYKHSKIY” OPEN-PIT MINE SUSTAINABILITY ASSURANCE

DOI: http://dx.doi.org/10.18796/0041-5790-2015-12-49-51

\section{Author}

Osharov A.V. ${ }^{1}$

1"Izykhskiy" open-pit mine OJSC, Belyi Yar, 655650, the Republic of Khakassia, Russian Federation

\section{Authors' Information}

Osharov A.V., Executive Director, tel.: +7 (39041) 2-92-00

\section{Abstract}

The article explains the conditions that determined the urgent necessity for investment attractiveness of coal mine. The measures for coal mine sustainability enhancement and results of their implementation were reviewed.

\section{Keywords}

Sustainability, investment attractiveness, coal strip mine, organization, technology, assurance solutions.

\section{References}

1. Artemyev V.B. Strateghiya organizatsionno-tekhnologicheskogo razvitiya ugledobychi v OAO "SUEK" [Strategic policy of organizational and technological development of coal production in "SUEK" OJSC]. Ugol' - Russian Coal Journal, 2008, Special issue, p. 11.

2. Galkin V.A. Sozidateknyi i razrushitelnyi potential organizatsii proizvodstva [Creative and destructive potential of facility management]. Gornyy Informatsionno-Analiticheskiy Byulleten - Mining Information-Analytical Bulletin, 2015, no. 10, Special issue, no. 45.

3. Kilin A.B., Kostarev A.S. \& Poleschuk M.N. Rol konkordatsii v investitsionnoy deyatelnosti ugledobyvayuschikh predpriyatiy OOO"SUEK-Khakassia". Organizatsiya i upravlenie gornym predpriyatiem [The role of concordance in the investment activities at coal mining enterprises of "SUEK-Khakassia" LLC. Organization and management of coal mining enterprise]. Gornyy Informatsionno-Analiticheskiy Byulleten - Mining Information-Analytical Bulletin, 2014, no. OB5, pp. 48-59.

4. Osharov A.V. \& Zakharov S.I. Analiz struktury rabochego vremeni rukovoditeley na ugolnom razreze. Organizatsiya i upravlenie gornym predpriyatiem [Analysis of coal mine managers working time breakdown structure]. Gornyy Informatsionno-Analiticheskiy Byulleten - Mining Information-Analytical Bulletin, 2014, no. OB5, pp. 159-167. 


\section{Энергетическая стратегия России ЭС-2030,}

\section{ее приоритеты и новые ответы внешним вызовам (аспект специфики стратегий региональных ТЭК)}

DOI: http://dx. doi. org/10.18796/0041-5790-2015-12-52-54

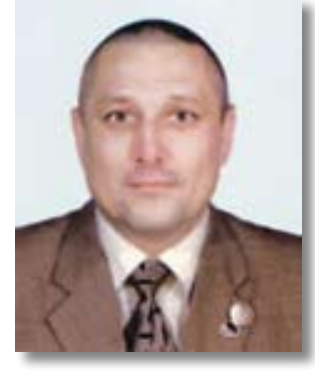

\section{НОВОСЕЛОВ}

Сергей Вениаминович

Академик МАНЭБ, канд. экон. наук, 650000 , г. Кемерово, Россия,

тел.: +7 (950) 273-31-86,

e-mail:nowosyolow.sergej@yandex.ru

В статье приведена характеристика современного ТЭК России, раскрыты проблемы, возникающие в сфере ТЭК в связи с кризисными явлениями в мировом сообществе. Показаны цели энергетической политики России ЭС-2020, ЭС-2030. Предложены основные направления развития региональных ТЭК России и их реализация и оценка на период 2020-2030 гг.

Ключевые слова: энергетическая стратегия, внешние вызовы, адаптация к внешней среде, логистика главных потоков энергоресурсов, технологическая парадигмаразвития производства, классификация региональных ТЭК.

Если рассматривать эволюцию развития энергетики России начиная с результатов плана ГОЭЛРО ${ }^{*}$ (1920г., предусматривалось сооружение 30 районныхэлектростанций мощностью 1,75 млн кВт при выработке 8,8 млрд кВт.ч), который был реализован к 1931 г. и до настоящего времени, когда уже функционируют 600 электростанций общей установленной мощностью 218145,8 МВт с выработкой электроэнергии порядка 1037 млрд кВт.ч, то, безусловно, очевиден рост энергетики страны в 118 раз за сто лет. Для абсолютного сравнения производства электроэнергии в России с некоторыми странами можно привести следующий ряд: в США - 4110 трлн кВт.ч, Китай - 3451 трлнкВт.ч, Япония - 957 трлнкВт.ч, Индия - 793 трлн кВт.ч, Германия - 593 трлн кВт.ч, Франция - 535 трлнкВт.ч, Украина - 172 трлнкВт.ч, Эстония - 11,4 трлн кВт.ч, Грузия - 7,97 трлн кВт.ч, Казахстан 78 трлн кВт.ч, Беларусь - 29 трлн кВт.ч в год [1]. Очевиден факт порядкового разрыва в производстве электроэнергии четырех лидеров - США, Китая, России и Японии с любыми другими странами (Евросоюз дает порядка 3080 трлн кВт.ч, но сравнивать его с Россией некорректно, так как это группа стран). Кроме того, для достоверного сравнения кроме абсолютных величин, нужны и относительные показатели, характеризующие качественные характеристики энерго-

* ГОЭЛРО - план государственной электрификации России. М.:БЭС, 1991. С. 331 потребления. Следующий важный факт — Россия находится на лидирующих позициях по добыче нефти, газа и угля, что говорит обуникальности ее топливно-энергетического комплекса (ТЭК).

Существующие энергетические стратегии ЭС-2020 и ЭС-2030 являются принципиально новыми документами стратегического планирования, носящими, не директивный характер, как план ГОЭЛРО и последующие пятилетние планы, а характер стратегических приоритетов и ориентиров, включая механизмы государственной энергетической политики на отдельных этапах ее реализации, обеспечивающих достижение намеченных целей $[2,3]$.

Однако развитие современных политических и экономических процессов иногда вносит неожиданные коррективы как в тактическое, так и в стратегическое управление ТЭК России, включая его региональные составляющие (региональные ТЭК).

В ходе последних событий в виде санкций ЕС и США относительно России ее правительством активно проводится адекватная политика в рамках БРИКС и ШОС, в этом видится диверсификация энергетической стратегии России как в видах энергоресурсов, технологиях, таки в логистике основныхэнергетических потоков на мировом рынке: запад — юг — восток. Северный и Южный потоки направлены в Турцию и страны Европы, а Восточный - в Китай и другие страны Азии.

Северный поток, трасса Nord Stream (Выборг-Грайфсвальд), две нити длиной 1204 км - имеют мощность 55 млрд куб. м газа в год [1]. Южный поток в Турцию - 63 млрд куб. м газа в год [1]. Восточный нефтепровод (трубопроводная система «Восточная Сибирь - Тихий океан», Тайшет - Козьмино) соединяет месторождения Западной и Восточной Сибири с рынками Китая и других стран Азии, мощность нефтепровода составляет до 58 млн т в год. Объем поставок газа в Китай по западному и восточному вариантам составит суммарно около 70 млрд куб.м [4]. Очевидна логистика главных потоков энергоресурсов государственной энергетической стратегии России с центром в Сибири.

Стратегия поставок Россией энергоносителей на внешний рынок напрямую связана с развитием регионов, где проходят данные потоки (магистральные трубопроводы), во многом определяет развитие региональных ТЭК России. Следует учесть, что логистику стратегии, определяют различные факторы политической, экономической, технологической и экологической сред, а для регионов имеется своя специфика формирования транспортных систем, в основном это климат и освоенность территорий.

Согласно ЭС-2030 целью энергетической политики России является максимально эффективное использование природных энергетических ресурсов и потенциала энергетического сектора для устойчивого роста экономики, по- 
вышения качества жизни населения страны и содействия укреплению ее внешнеэкономических позиций. В свою очередь стратегической целью региональной энергетической политики является создание устойчивой и способной к саморегулированию системы обеспечения региональной энергетической безопасности с учетом оптимизации территориальной структуры производства и потребления топливно-энергетических ресурсов [3].

Исходя из этого, направленность региональной энергетической политики должна быть максимально ориентирована на приоритеты государственной энергетической стратегии. В свою очередь региональную энергетическую стратегию формируют как факторы внешней среды (главенствующие со стороны федеральных целей), так и внутренние факторы, определенные интересами региона. Следует отметить, что для конкурентоспособной экономики приоритет отдается целям самого государства, хотя в настоящее время многие страны в аспекте энергобезопасности зависимы от внешней среды (например, Греция, Украина и другие) и зависимы не только в технологическом плане, но и в финансовом.

Напряженная конкуренция на мировом рынке углеводородов влияет и на Россию, однако «рублевая зона» внутри страны стабилизирует экономические процессы, а продуманная, умеренная финансово-экономическая политика сдерживает инфляцию, что поддерживает цены на энергоносители в России на одном уровне, и дает лишь незначительное сокращение спада ВВП. Так снижение роста ВВПРФ за июнь 2015 г. составило 4,2\% при инфляции 8,5\% (которая снизилась на 0,2\%), а индекс физического объема ВВП снизился лишь на 2,2\% [5]. Следует учесть, что к России применены санкции, снизилась цена на нефть со 121,4дол. США за баррель в 2012 г. до 50,83 дол. США за баррель в июле 2015 года [6], также, снизился курс рубля, плюс Крым вошел в состав России.

Благодаря проводимой экономической политике центра регионам удалось максимально снизить падение объемов ВРП в кризисных условиях. Относительно развития региональных ТЭК - базы экономик регионов, необходим учет современных требований энергетического рынка и новой технологической парадигмы развития производства, которые предопределяют трансформацию энергоемких региональных ТЭК в энергоэффективные. По региональной дифференциации региональные ТЭК можно классифицировать на: энергоизбыточные, энергодефицитные и стратегические. Поэтому при разработке стратегий региональных ТЭК основной упор должен делаться на его территориальную специфику и классификационный признак.

По результатам научного поиска и исследований, проводимых с момента реформирования ТЭК РФ, автор выделяет

\section{Направления стратегического развития региональных ТЭК на период 2020-2030 гг.}

Наименование
направления развития ТЭК
Поиск и освоение новых ре-
сурсных месторождений ТЭР
Строительство новых энерге-
тических производств регио-
нального ТЭК
Расширение транспортно-
коммуникационной системы
Расширение экспорта энергоре-
сурсов из региона
Формирование новых форм
организационно-технологи-
ческих систем

Формирование высокорентабельных энергопроизводств

Формирование технологий
замкнутого цикла
Формирование экологически
чистых производств

Оптимизация энергетических Создание оптимальной секторов регионального ТЭК структуры регионального

Комплексное использование Создание диверсифициронескольких вышеперечислен- ванной структуры регионых направлений ТЭК

\begin{tabular}{l}
\multicolumn{1}{c}{ Негативы } \\
Интенсивнови \\
вание месторождений \\
ТЭР \\
Высокие капитальные
\end{tabular}

Создание новых энерготех- Высокие капитальные нологий

Увеличение пропускной способности транспортной системы регионального ТЭК

валютных поступлений в регион

Повышение КПД генерации Дс электро - и теплоэнергии

\section{Создание энерготехно-} логий с расширенным ассортиментом продукции и добавленной стоимостью Минимизация отходов при производстве энергопродукции

Снижение антропогенной нагрузки на экологию

нального ТЭК с высокой адаптацией к внешней среде затрать

Увеличение затрат на

транспорт энергии

Дополнительные

затраты на транспорт энергоресурсов

Дополнительные финансовые затраты на реализацию инновационных проектов энергопроизводств Дополнительные финансовые затраты на реализацию безотход-

ных технологий

Дополнительные финансовые затраты на реализацию технологий замкнутого цикла

-

\section{Оценка
направления \\ Экстенсивная}

Модернизация

регионального ТЭК

Экстенсивная модернизация

Конкурентная

Инновационная Формирование высокоэффективных энергопредприятий

Прогрессивная Повышение рентабельности энергопредприятий

Прогрессивная Ресурсосбережение Социально-на-
правленная

Формирование системы экологической безопасности в региональном ТЭК

Прогрессивная Максимальная экономия ресурсов

Высоко-адапта- Максимальная прибыль в ционная кризисных условиях 
следующие основные специфические направления развития региональных ТЭК России, приемлемые для реализации на период 2020-2030 гг. (см. таблицу).

Резюмируя, можно отметить, что на современном этапе развития для региональных ТЭК стратегические тенденции определены инновационным развитием, связанным с требованием конъюнктуры энергетического рынка и энергетической безопасностью страны. При учете последних событий в мире (санкции, скачки цен на нефть, падение курса рубля) при разработке региональныхэнергетических стратегий необходимо создание оптимального резерва финансов и организационных действий для обеспечения гибкой адаптации стратегических действий к внешним вызовам.

Для обеспечения решения таких задач необходим системный мониторинг конъюнктуры как мирового энергетического рынка, так и внутреннего, который включает основные элементы: финансовый мониторинг, маркетинговый, технологический, организационный, экологический.

\section{Список литературы}

1. Сайт: http://informatsiya. ru/tabl/27.

2. Энергетическая стратегия России на период до 2020 года. Распоряжение Правительства Российской Федерации от 28 августа 2003 г. №1234-р.

3. Энергетическая стратегия России на период до 2030 года. Распоряжение Правительства Российской Федерации от 13 ноября 2009 г. №1715-р.

4. Сайт: http://minenergo. gov. ru.

5. Сайт: http://economy. gov. ru/minec/resources/

6. Российская газета, 4 августа 2015 г. №170 (6741)
UDC 338.1.620.9:658.012 @ S.V. Novoselov, 2015 ISSN 0041-5790 (Print) • ISSN 2412-8333 (Online) • Ugol' — Russian Coal Journal, 2015, № 12, pp. 52-54

Title

ENERGY STRATEGY OF RUSSIA - ES-2030, IT PRIORITIES

AND NEW RESPONSES TO THE EXTERNAL CHALLENGES

(SPECIFICS OF REGIONAL FUEL AND ENERGY SECTOR STRATEGIES)

DOI: http://dx.doi.org/10.18796/0041-5790-2015-12-52-54

Author

Novoselov S.V.'

${ }^{1}$ MANEB Academy, Kemerovo, 650000, Russian Federation,

tel.: +7 (950) 273-31-86, e-mail: nowosyolow.sergej@yandex.ru

Authors' Information

Novoselov S.V., member of MANEB Academy, PhD (Economics)

\section{Abstract}

The article characterizes the present-day fuel and energy sector of Russian Federation, exposes the problems which occur in the FEC field as related to the signs of crisis in the world community. The targets of energy policy of Russia, ES-2000, ES-2030 are presented. The principal directions of regional FECs development and their implementation and assessment in 2020-2030 are proposed.

Keywords

Energy strategy, external challenges, adaptation to the external environment, logistics of major flows of energy resources, technological paradigm of industrial development, classification of regional FECs.

\section{References}

1. Available at: http: //informatsiya.ru/tabl/27 (accessed 12.10.2015).

2. Energeticheskaya strategiya Rossii na period do 2020 goda [Energy strategy of Russia for the period up to 2020]. Decree of the Russian Federation Government, no. 1234-r of August 28, 2003.

3. Energeticheskaya strategiya Rossii na period do 2030 goda [Energy strategy of Russia for the period up to 2030]. Decree of the Russian Federation Government no. 1715-r of November 13, 2009.

4. Available at: http: //minenergo.gov.ru (accessed 12.10.2015).

5. Available at: http://economy.gov.ru/minec/resources/ (accessed 12.10.2015).

6. Rossiyskaya Gazeta, August 04, 2015, no. 170 (6741).
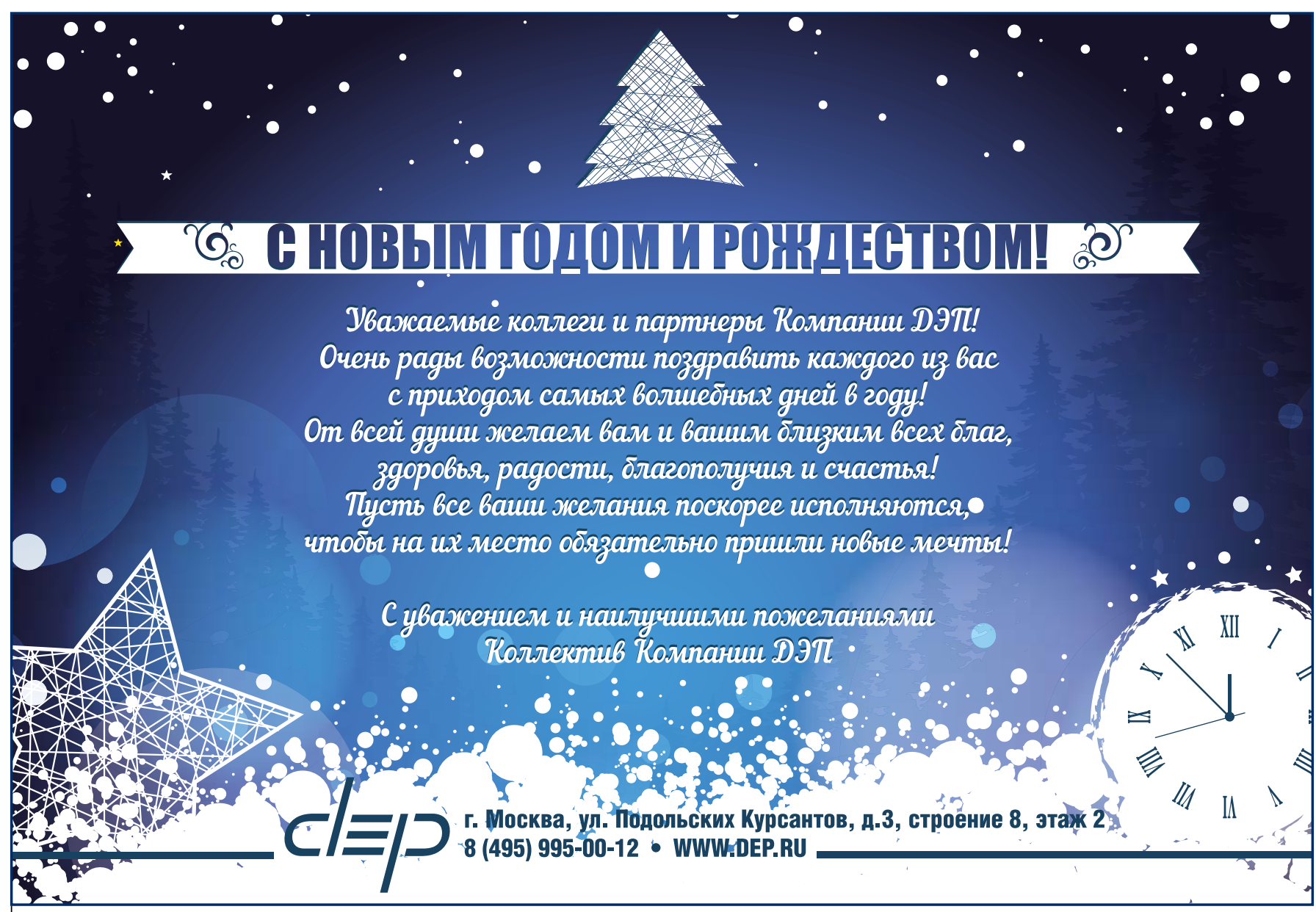


\section{досрочно выполнил годовой план}

В конце ноября 2015 г. коллектив разреза «Восточный» (ЗАО «Салек», АО ХК "СДС-Уголь») досрочно рапортовал о выполнении годового плана по угледобыче. Горняки предприятия добыли 3 млн 772 тыс. $m$ угля. Это наивысший показатель добычи с момента запуска предприятия.

Утреннюю смену горняков, рапортовавшую о выполнении годового плана, на предприятии встретили огнями новогодней елки и праздничными фейерверками. Производственное достижение на предприятии стало возможным благодаря слаженным действиям коллектива. В первую очередь это заслуга всей инженерно-технической службы $3 \mathrm{AO}$ «Салек». Весомый вклад внесли экипажи и бригады под руководством Евгения Бочарова (Hitachi EX 3600), Александра Самарина (БелАЗ 75306), Сергея Жукова (CAT9R). Особо стоит отметить профессионализм начальников: участка АРM - Алексея Гуляева, дренажного участка - Алексея Хузина, смены - Михаила Никулина, управления горных работ - Дмитрия Манаенкова.

Разрез «Восточный» запущен в эксплуатацию 19 августа 2010 г. В 2015 г. коллектив разреза отметил 5-летний юбилей. Со дня запуска предприятия в эксплуатацию горняки отгрузили потребителям более 20 млн т угля.
До конца 2015 года коллектив разреза «Восточный» планирует добыть еще более 400 тыс. т и выйти на проектную мощность 4,2 млн т угля в год.

\section{Наша справка.}

АО ХК «СДС-Уголь» входит в тройку лидеров отрасли в России. По итогам 2014 года предприятия компании XК «СДС-Уголь» добыли 28,5 млн т угля. 88\% добываемого угля поставляется на экспорт. АО ХК «СДС-Уголь» является отраслевым холдингом АО ХК «Сибирский Деловой Союз». В зону ответственности компании входят 16 предприятий, расположенных на территории Кемеровской облас-

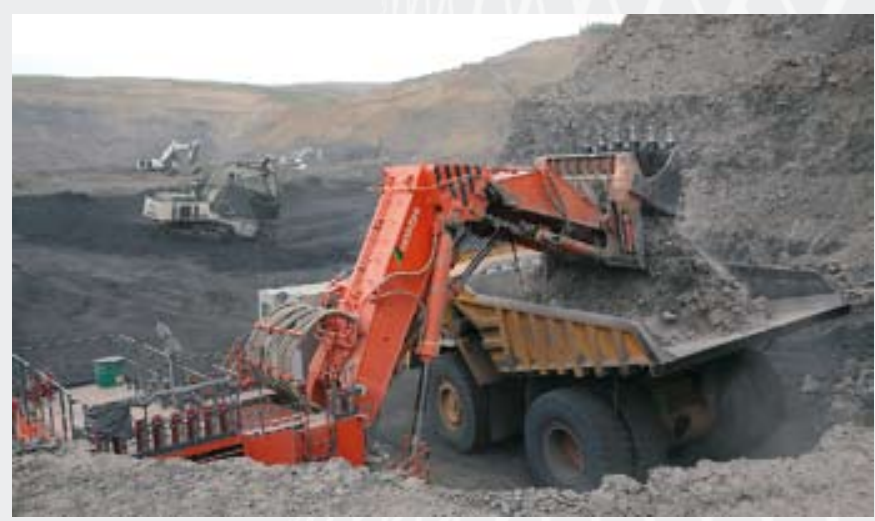

\section{Шахта «Комсомолец» ОАО «СУЭК-Кузбасо» достигла рекордного показателя добычи в своей истории}

18 ноября 2015 г. бригада Кирилла Куксова участка №4 (начальник Алексей Огнев) шахты "Комсомолец» ОАО «СУЭК-Кузбасс» добыла с начала года двухмиллионную тонну угля. Такой результат достигнут впервые за всю 82-летнюю историю предприятия. В этот же день коллектив обогатительной фабрики шахты «Комсомолец» досрочно выполнил годовой производственный план 2 млн 247 mыс. $m$.

Достичь таких результатов предприятию удалось благодаря реализации масштабных инвестиционных проектов в рамках долгосрочной стратегической программы СУЭК по развитию предприятий ОАО «СУЭК-Кузбасс», утвержденной Советом директоров под руководством Андрея Мельниченко.

В частности, только за последние три года в развитие обогатительной фабрики шахты «Комсомолец» вложено более 750 млн руб. Приобретено новое оборудование, построены дополнительные здания и галереи. Технологический цикл теперь осуществляется с замкнутой водно-

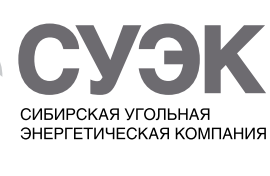

шламовой схемой, что позволяет избежать воздействия на окружающую среду за счет отказа от сброса шламовых вод.

Значительные инвестиции вложены компанией в модернизацию транспортной цепочки, обновление горношахтного оборудования, оснащение современными системами безопасности. Как результат, увеличилась нагрузка на очистной забой - до 8-10тыс. т в сутки. Фактически, двухмиллионного рубежа бригада Кирилла Куксова в 2015 г. достигла за восемь месяцев - два месяца занял перемонтаж из лавы в лаву забойного оборудования - 174 секции комплекса Glinik (Польша), комбайн SL-300 и лавный конвейер SH PF-4/1032 (Германия).

Митинг в честь исторического рекорда очистников состоялся непосредственно в устье ствола шахты. Директор Василий Стецик, поблагодарив горняков за высокий профессионализм и организованность, выразил уверенность В том, что к новогодним праздникам достижение бригады станет весомей еще на полмиллиона тонн. А в недалекой перспективе шахта-лава способна выйти на годовой уровень добычи и в три миллиона тонн. 


\section{Защита органов дыхания работников добывающих предприятий}

DOI: http://dx. doi. org/10.18796/0041-5790-2015-12-56-59

\section{БАРКАЛОВА Нина Юрьевна}

Старший технический спечиалист отдела средств индивидуальной защиты

ЗАО «ЗМ Россия», 121614, г. Москва, Россия, тел.: +7 (495) 784-74-74, e-mail: nbarkalova@3M.com

Рабочие добывающих предприятий подвержены влиянию многочисленных вредных факторов, приводящих к профессиональным заболеваниям органов дыхания. В статье рассмотрены заболевания и профпатологии, к которым приводит повышенный уровень АПФД на рабочих местах шахтеров и горняков. Единственный способ профилактики - избегать контакта с пылью, то есть использовать СИЗОД. В статье представлен обзор различных средств защиты органов дыхания: фильтрующих полумасок, полумасок и полнолицевых масок из изолирующих материалов, систем с подачей воздуха.

Ключевые слова: защита органов дыхания, СИЗ, СИЗОД, средства защиты органов дыхания, безопасность, профессиональные заболевания.

\section{ПРОБЛЕМА. КАКИЕ ОПАСНОСТИ ПОДСТЕРЕГАЮТ РАБОТНИКОВ ДОБЫВАЮЩИХ ПРЕДПРИЯТИЙ?}

Шахтеры-угольщики, горняки, занятые в добыче каких бы то ни было полезных ископаемыхподвержены влиянию многочисленных вредных факторов, приводящих к профессиональным заболеваниям, в том числе и нарушениям функции легких.

Для шахт и рудников к таким вредным факторам относятся повышенная концентрация аэрозолей, измененный состав воздуха (снижение содержания кислорода, повышение концентраций углекислого газа, газов, образующихся при взрывных работах, выхлопных газов от работающей под землей техники). Высокая пылевая нагрузка на легкие проходчиков и горнорабочих обусловливается также тем, что проведение проходческих работ, любые процессы бурения, шахтостроительные работы технологически связаны с выделением большого количества пыли - измельченной породы, что на фоне гипервентиляции легких (из-за измененного состава воздуха с пониженным уровнем кислорода и активного физического труда) приводит к высокому уровню профессиональных заболеваний органов дыхания.

При открытой добыче угля и руды все технологические процессы также сопровождаются выделением аэрозолей преимущественно фиброгенного действия (АПФД) и газов от взрывных работ, газов от работающей в карьере техники, так как они тяжелее воздуха, то они также опускаются на дно карьера. Показатели запыленности разнятся в зависимости от рабочих мест - для машинистов экскаваторов и машинистов бульдозеров среднее значение - около 3 ПДК, для машинистов тепловозов - 4,7 ПДК, для водителей технологического транспорта - около 4 ПДК, для машинистов железнодорожного транспорта - до 6,7 ПДК.

Рассмотрим подробнее заболевания и профпатологии, к которым приводит повышенный уровень АПФД на рабочих местах шахтеров и горняков.

- Пневмокониоз (антракоз, силикоз)

Пневмокониоз - это заболевание, которое возникает вследствие воспалительной и фиброзной реакции легких на АПФД. Данное заболевание опасно тем, что выявляется рентгенографически не сразу - патологические изменения могут присутствовать в легких задолго до их обнаружения. Опасность пневмокониозов состоит еще и в том, что они имеют хроническое бессимптомное течение. На сегодняшний день не существует эффективного лечения, останавливающего фиброзный процесс в легких. Способы, которые используются сейчас (ингаляция алюминиевого порошка, полный лаваж легких) имеют большое количество рисков и осложнений.

- Прогрессивный выраженный фиброз

При дальнейшем развитии пневмокониоза он переходит в прогрессивный фиброз, причем развитие болезни не останавливается при прекращении действия АПФД и часто приводит к потере трудоспособности и смерти. На данный момент способов лечения данной профпатологии нет. Медицинская помощь направлена только на улучшение текущего состояния и борьбу с сопутствующими инфекциями легких, что предотвращает появление осложнений. Единственный способ профилактики - избегать контакта с пылью, то есть использовать СИЗОД.

- Хронический пылевой бронхит

Такие респираторные симптомы, как постоянный кашель и образование мокроты также связывают с воздействием АПФД, они часто являются профзаболеваниями в горнодобывающей промышленности (рис. 1).

\section{- Эмфизема}

Статистика подтверждает более высокую вероятность возникновения эмфиземы у горняков по сравнению с другими контрольными группами.

Кроме этого, необходимо упомянуть и то, что многие вещества в рабочей зоне, как при работе в шахтах и карьерах, так и при открытой добыче, являются канцерогенами (бензопирены, кремнезем и т. д.). Кроме этого, канцерогенной может быть и сама руда (никелевая, урановая и т.д.). По статистике выявленных онкозаболеваний, проходчик и горнорабочий всегда входят в пятерку зарегистрированных случаев профзаболеваний. 
ВЕДУЩИЕ ПРОФЕССИИ РАБОТНИКОВ, У КОТОРЫХ БЫЛ ВЫЯВЛЕН ХРОНИЧЕСКИЙ ПЫЛЕВОЙ БРОНХИТ (\%)

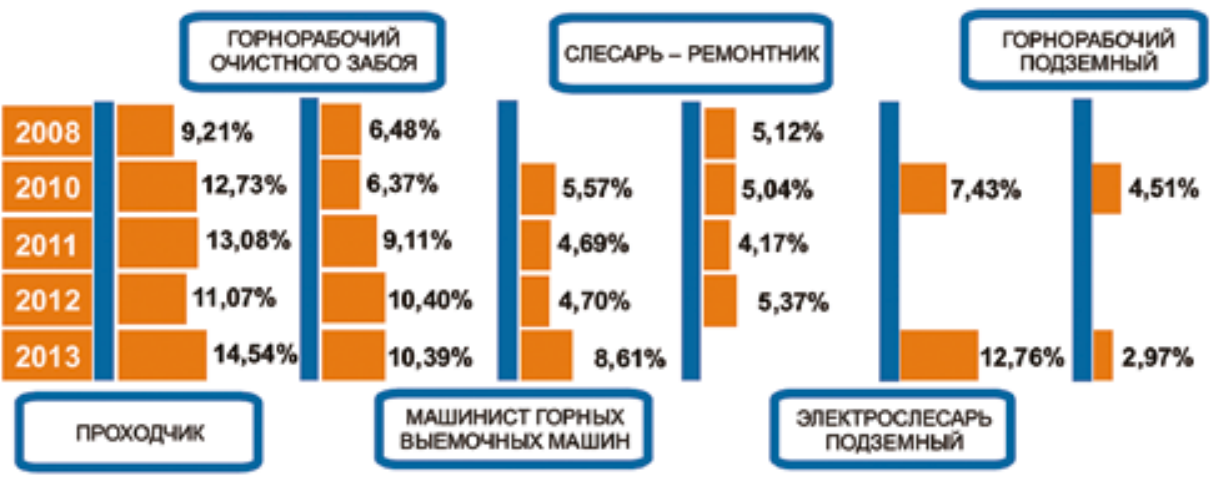

Рис. 1. Работники ведущих профессий,

у которых был выявлен хронический пылевой бронхит, \%

\section{РЕШЕНИЕ. СРЕДСТВА ИНДИВИДУАЛЬНОЙ ЗАЩИТЫ ОРГАНОВ ДЫХАНИЯ ПРИ РАБОТЕ НА ДОБЫВАЮЩИХ ПРЕДПРИЯТИЯХ}

Сегодня на российском рынке представлено огромное количество различных средств защиты органов дыхания - фильтрующие полумаски (респираторы), полумаски и полнолицевые маски из изолирующих материалов, системы с подачей воздуха. При этом важно понимать, что не существует универсальных средств для защиты органов дыхания при работах любого уровня сложности и подбирать СИЗ необходимо в соответствии с видами деятельности предприятий и особенностями условий труда конкретных работников.

Фильтрующие полумаски могут быть различной формы и конструкции - складные, чашеобразные. Респираторы могут быть как одноразового использования (маркировка NR), так и иметь, например, специальную зону обтюрации материала, который можно гигиенически обрабатывать и, таким образом, использовать более чем одну смену (маркировка R). Респираторы бывают следующих степеней защиты - FFP1, FFP2, FFP3 (до 4, 12, 50 ПДК соответственно). Также респираторы могут иметь различные конструктивные особенности, например язычки для более удобного одевания в загрязненных условиях, потовпитывающие прокладки на переносице, металлические зажимы для более плотной посадки респиратора в зоне переносицы и так далее, но очень важной особенностью, в значительной степени влияющей на комфорт работника, является наличие клапана выдоха.

Компания 3М как эксперт в области средств индивидуальной защиты работает на российском рынке уже более 20 лет, предлагая предприятиям самые современные и качественные СИЗОД. В 2008 г. компания открыла собственное производство фильтрующихполумасокв Волоколамске. В 2012 г. в Волоколамске начала работу научно-исследовательская лаборатория, которая обеспечивает контроль качества производимой продукции и занимается разработкой новых продуктов и решений с учетом специфики российского рынка.

В портфеле компании присутствует широкий ассортимент складных и формованных респираторов всех степеней защиты.

Фильтрующие полумаски Aura серии 9300+ имеют уникальную трехпанельную конструкцию, впервые разработанную и запатентованную компанией $3 \mathrm{M}$ (рис. 2).

Уникальность трехпанельной конструкции - в обеспечении надежного прилегания фильтрующей полумаски к лицу рабочего, в большей площади фильтрующей поверхности, благодаря чему респиратор «работает» значительно дольше и обеспечивает комфортное низкое сопротивление дыханию (особенно важно при работе в условиях высокой запыленности).

В процессе производства большинства современных респираторов используются фильтры электростатического действия, которые долго сохраняют заряд, не повреждаются водой и растворителями. Дополнительный механизм улавливания частиц, помимо механической фильтрации, обеспечивает более эффективную защиту при минимальном сопротивлении воздушному потоку. Фильтрующий материал полумасок $3 \mathrm{M}^{\mathrm{TM}}$ также является фильтром электростатического дейс-

Puc. 3. Клапан выдоха $3 M^{\mathrm{TM}} \mathrm{Cool}^{\text {Flow }^{\mathrm{TM}}}$

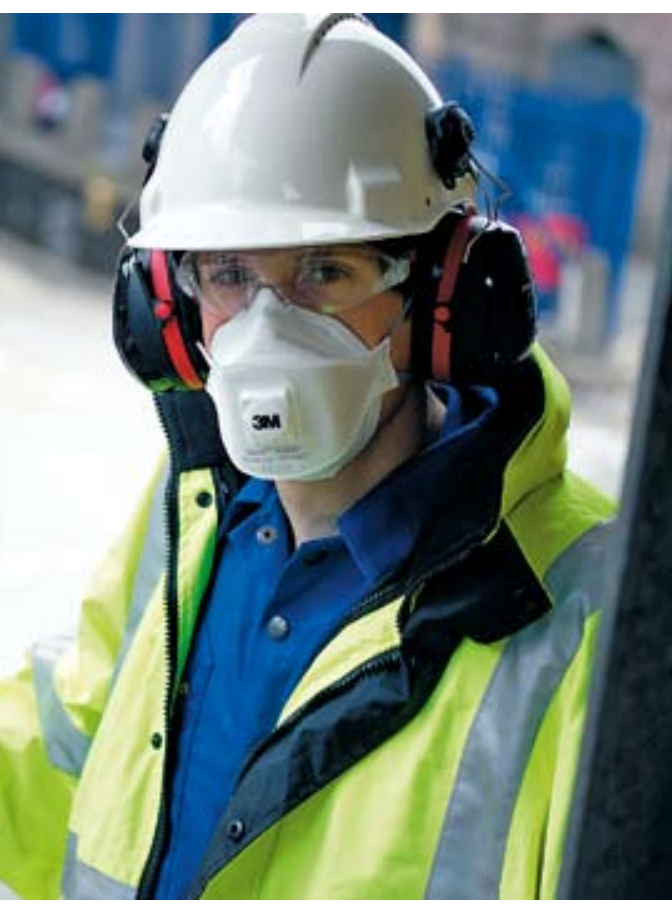




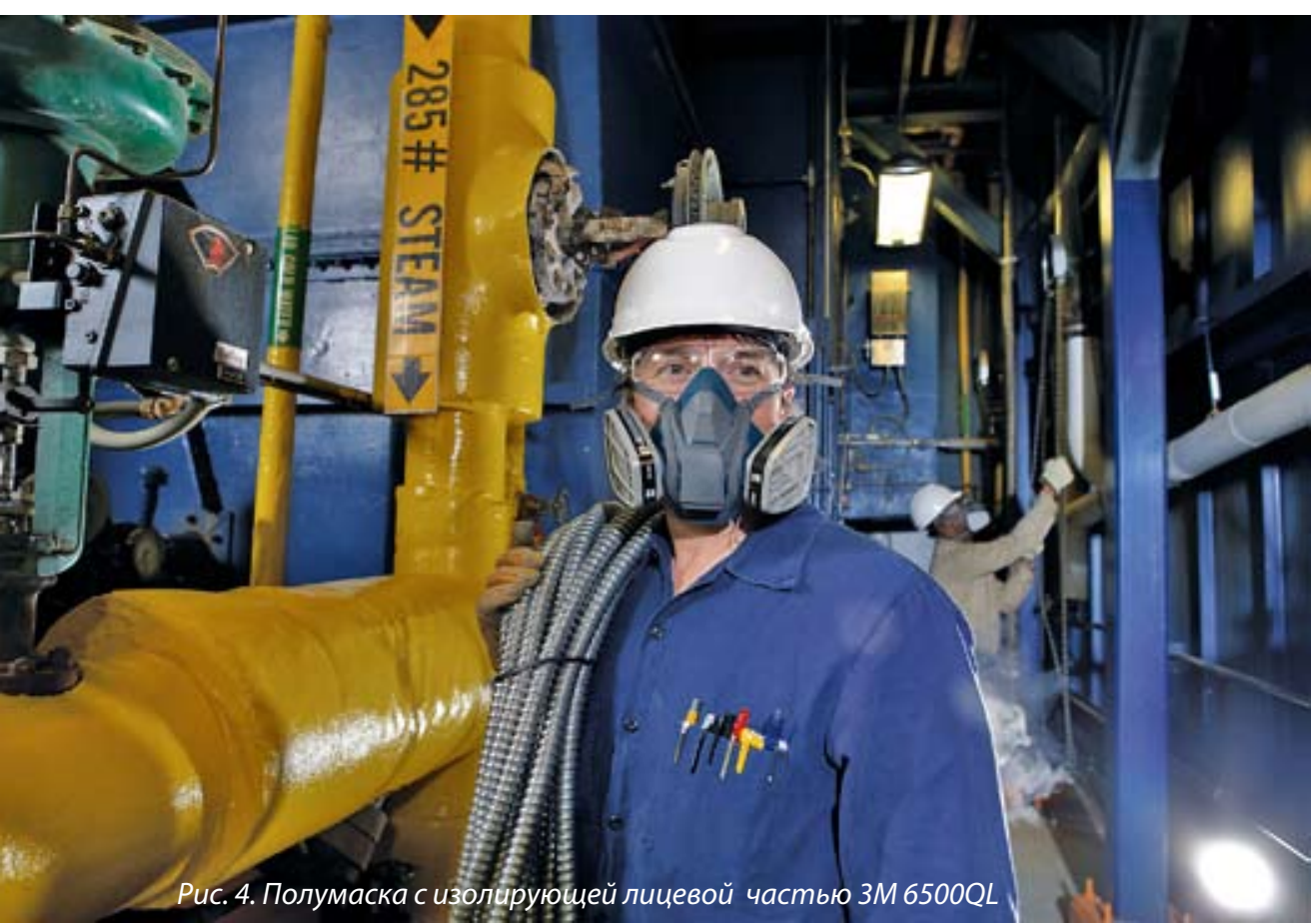

пресса. Поэтому основное «сопротивление дыханию», которое ощущается работником при использовании фильтрующих СИЗОД как раз происходит на выдохе.

Благодаря своей конструкции клапан $3 \mathrm{M}^{\mathrm{TM}}$ Cool Flow ${ }^{\mathrm{TM}}$ позволяет быстро и в большом объеме отвести воздушные массы из подмасочного пространства, что обеспечивает легкость дыхания. Кроме этого, воздух, выходящий из легких, нагрет до температуры, близкой к температуре тела - около $30^{\circ} \mathrm{C}$ и имеет высокую влажность. А клапан выдоха позволяет снизить температуру в подмасочном пространстве, что обеспечивает высокий уровень комфорта, что в свою очередь напрямую влияет на снижение утомляемости работника, повышение уровня его концентрации и производительности труда.

Очень важно также, чтобы респира-

твия, однако процесс его производства принципиально отличается от всех других методом нанесения заряда и является уникальной разработкой компании $3 \mathrm{M}$.

В респираторах 3М, а именно в клапанных моделях се-

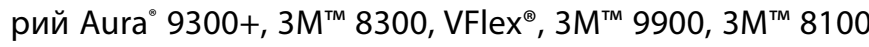
установлен запатентованный клапан выдоха $3 M^{\text {тм }}$ Cool Flow $^{\text {TM }}$ (рис. 3).

Именно респираторы с клапаном выдоха рекомендуется использовать при работе на шахтах и рудниках, в зависимости от концентрации и ПДК вредных веществ.

В чем заключается работа клапана выдоха? Мы знаем, что вдох осуществляется человеком за счет активной работы дыхательных мышц, а выдох происходит пассивно - в результате расслабления диафрагмы и спадения легких, кроме случаев активного выдоха с участием мышц

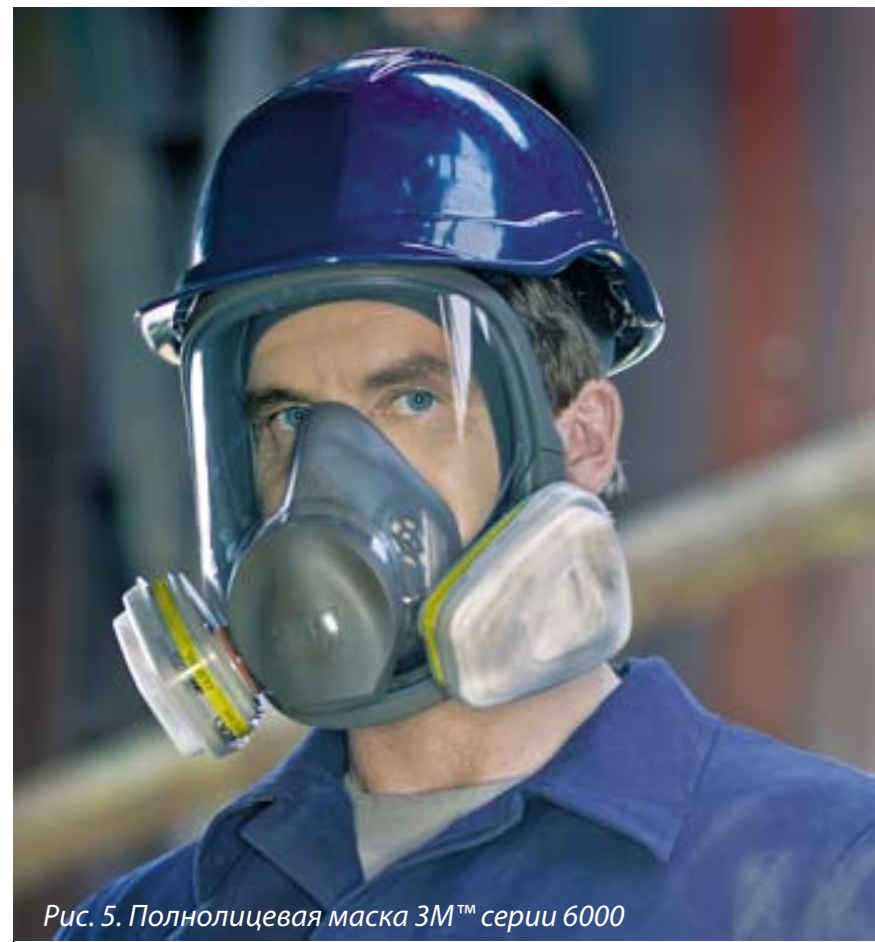

тор имел хорошее прилегание по зоне обтюрации, был в достаточной степени универсален при использовании работниками с различными типами и размерами лиц. Используемые в респираторах $3 \mathrm{M}^{\mathrm{TM}}$ носовые металлические зажимы позволяют им плотно прилегать к лицу вне зависимости от его типа и формы, не допуская щелей.

При наличии в рабочей зоне наряду с пылью и аэрозолями различных газов в пределах ПДК (или выше для некоторых газов) могут использоваться респираторы $3 \mathrm{M}^{\mathrm{TM}}$ 9914P (с защитой от органики) и $3 \mathrm{M}^{\mathrm{TM}} 9926 \mathrm{P}$ (с защитой от кислых газов) с дополнительной противогазовой защитой. В них наряду со слоем противоаэрозольного фильтра используется слой угольного фильтра.

Кроме этого, при работе в зоне с сильной запыленностью, при сложных климатических условиях рекомендуется использовать полумаски из изолирующих материалов $3 \mathrm{M}^{\mathrm{TM}}$ серии 7500 или 6500QL (рuс. 4), которые в зависимости от условий могут быть оснащены как противоаэрозольными или противогазовыми фильтрами, так и комбинированными фильтрами, например противогазовым фильтром с предфильтром, защищающим от пыли и аэрозолей. Защита может быть до 50 ПДК.

В сложных условиях возможно использование полнолицевой маски $3 \mathrm{M}^{\mathrm{TM}}$ серии 6000 (рис. 5), которая в комбинации с фильтрами может обеспечить защиту органов дыхания работника до 200 ПДК от газов или пыли (или в комбинации до 200 ПДК от газов и до 50 ПДК от пыли и аэрозолей).

Кроме этого, использование полнолицевой маски обеспечивает комплексную защиту работника - как органов дыхания, так и органов зрения.

Все вышеупомянутые СИЗОД имеют общую особенность - они имеют зону прилегания к лицу, таким образом, человек должен быть гладко выбрит, не иметь нарушений кожного покрова, шрамов и т.д. Однако существуют СИЗОД $3 \mathrm{M}^{\mathrm{Tm}}$ с принудительной подачей воздуха, которые обеспечивают как очень высокий уровень защиты органов дыхания работника, так и высокий уровень комфорта, не 
имея зоны обтюрации. Это могут быть как различные капюшоны, так и шлемы, обеспечивающие комплексную защиту лица и головы, которые используются совместно с блоком подачи воздуха $3 \mathrm{M}^{\mathrm{TM}}$ AdFlo (puc. 6).

Блоки, обеспечивающие принудительную подачу воздуха с одновременной фильтрацией (как аэрозолей, так и газов) могут быть оснащены различными головными частями - сварочным щитком с автоматически затемняющимся светофильтром Speedglasं, шлемом, лицевым щитком, капюшоном. В зависимости от выбора головной части защита от аэрозолей и пыли может составлять до 500 ПДК, таким образом, данные СИЗОД можно рекомендовать на самые сложные проходческие рабочие места. Кроме этого, постоянная подача воздуха в пространство под капюшон или щиток обеспечивает дополнительный комфорт для работника.

Осознание работником необходимости использования СИЗ и использование их в течение всей рабочей смены, на что в значительной степени влияют комфортность СИЗ и знание их корректного использования, являются, несомненно, основополагающими факторами в защите здоровья шахтера.

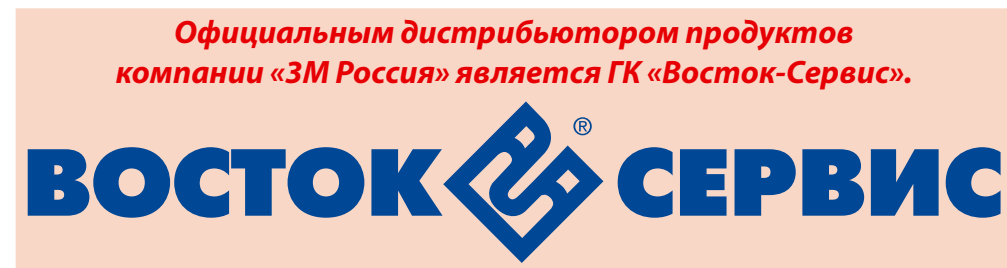

Центральный офис ГК «Восток-Сервис» в Москве

ЗАО «Восток-Сервис-Кузбасс» 109518, Москва,

2-й Грайвороновский проезд, д.34

Тел: +7 (495) 665-7-665

E-mail: td@vostok.ru

www.vostok.ru

\section{ЗМ Россия}

121614, Москва, ул. Крылатская, д. 17, стр. 3

Бизнес-парк «Крылатские холмы»

тел.: +7 (495) 7847474 (многоканальный)

www. 3mrussia. ru/mining

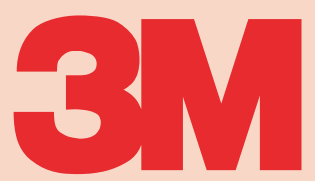

Специалисты отдела материалов для горнодобывающей промышленности:

\section{Москва}

\section{Вадим Васильев}

Директор по продажам

Отдела решений

для горнодобывающей

промышленности и металлургии моб. тел.: +7 (985) 818-14-62

\section{Кемерово}

Регион: Кузбасс,

Кемеровская область

Николай Булатов

моб. тел.: +7 (913) 301-57-40

\section{Челябинск}

Регион:

Башкирия, Южный Урал

Сергей Пшеничный

моб. тел.: +7 (912) 893-23-71

\section{Екатеринбург}

Регион: Урал, Северный Урал Андрей Кузьмин моб. тел.: +7 (912) 647-71-11

Алексей Красноперов моб. тел.: +7 (912) 610-20-15

Санкт-Петербург

Регион: Архангельская область, Республика Коми, Санкт-Петербург

\section{Михаил Попков}

моб. тел.: +7 (921) 849-97-11

\section{Красноярск}

Регион:

Сибирь и Дальний Восток

\section{Андрей Зоммер}

моб. тел.: +7 (983) 077-53-6

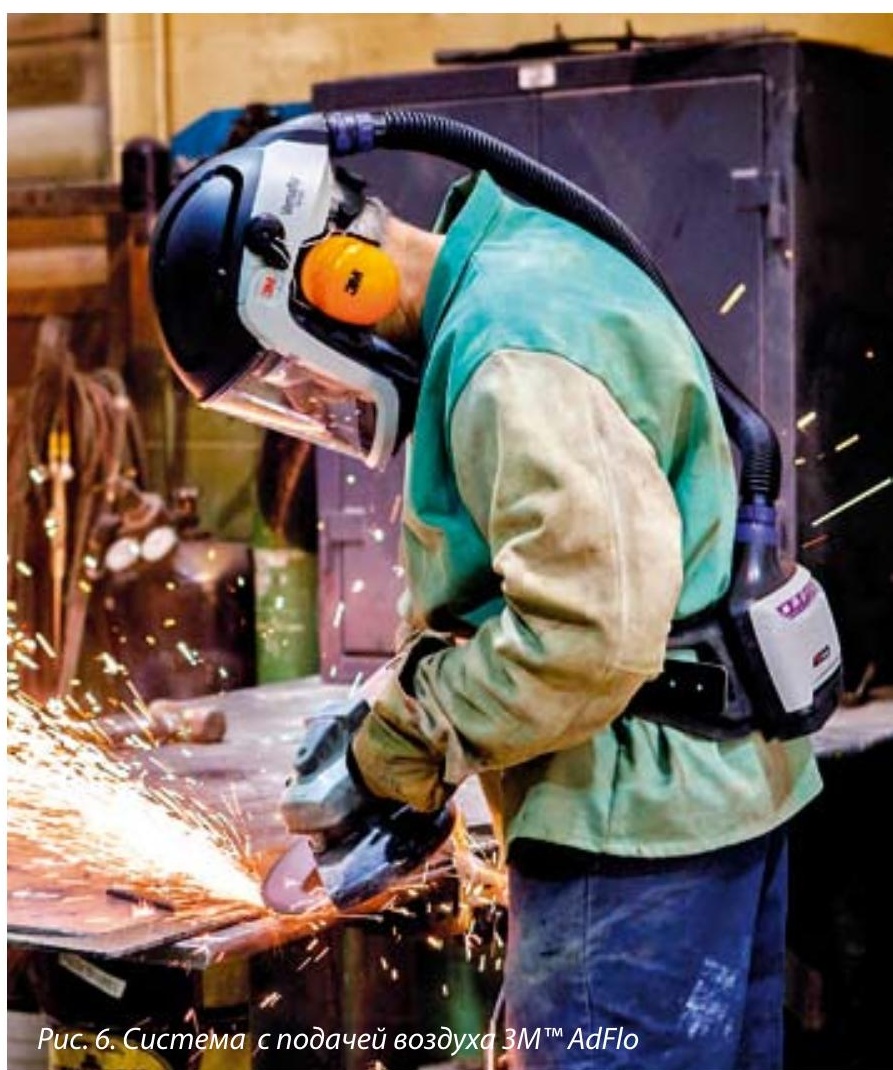

SAFETY

UDC 622.867.32:614.894 @ N. Yu. Barkalova, 2015 ISSN 0041-5790 (Print) • ISSN 2412-8333 (Online) • Ugol' — Russian Coal Journal, 2015, № 12, pp. 56-59

\section{Title}

\section{RESPIRATORY PROTECTION FOR MINING WORKERS}

DOI: http://dx. doi. org/10.18796/0041-5790-2015-12-56-59

\section{Author}

Barkalova N. Yu.

${ }^{1}$ 3M Russia, JSC, Moscow, 121614, Russia

\section{Authors' Information}

Barkalova N. Yu., snr. technical service engineer 3M LAB TS OH\&ES Local, tel.: +7 (495) 784-74-74,

e-mail: nbarkalova@3M.com

\section{Abstract}

Surface mining work presents a host of risks, and airborne contaminants can be one of the most dangerous. Contaminants in the air create respiratory hazards that can lead to severe and even fatal illness.

The article deals with respiratory ailments, which are common in the surface mining industry. The only way of prevention is to avoid contact with dust and use respiratory protective equipment. The article presents an overview of a variety of respiratory protective equipment - respirators, half masks and full face masks with insulating materials, powered and supplied air respirators.

\section{Keywords}

Respiratory protection, PPE, personal protective equipment, respiratory protective equipment, safety, occupational diseases. 


\section{С НОвЬМ ГОДОМ:}

\section{ООО НАУЧНО-ПРОИЗВОДСТВЕННОЕ ПРЕДПРИЯТИЕ «ЗАВОД МОДУЛЬНЫХ ДЕГАЗАЦИОННЫХ УСТАНОВОК»}

ООО «НПП «ЗавоА МАУ» было основано в 2009 году как завод-изготовитель модульных Аегазационных установок.

Основное направление 000 "НПП "Завод МАУ" производство оборудования Аия преАварительной дегазации разрабатываемых угольных пластов и откачивания метановозАушной смеси (MBC) из выработанного пространства шахты. Концентрация метана при этом может колебаться в пределах от 0\% AO $100 \%$.

ООО "НПП "ЗавоА МАУ" произвоАит МоАУАьНые Аегазационные установки (МАУ) на базе ротационных и водокольцевых насосов итальянской фабрики ROBUSCHI (Gardner Denver S.r.l.-Divisione ROBUSCHI). При изготовлении МАУ используются инновационные технологии с применением комплектующих самого высокого качества.

Установки типа МАУ с автоматизированной системой управления отвечают всем требованиям "Инструкции по Аегазации угольных шахт", "Инструкции по применению схем проветривания выемочных участков шахт с изолированным отводом метана из выработанного пространства с помощью газоотсасывающих установок".

За период с 2009 года по настоящее время произведено и введено в экспиуатацию около 100 еАиниц Аегазационных установок. Нашими клиентами являются ведущие угольные компании, такие как "СУЭК", "Южкузбассуголь", "Кузбассразрезуголь", "Сибуглемет", "Распадская", "ЗапСибУголь", "Заречная", "Белон", "ТопПром".

\section{0 «НПП «Завод МАУ» производит:}

Модульны е Аегаза ционны е (газоотсасывающие) установки Авух типов:

- на базе ротационных насосов;

- на базе водокольцевых насосов

Когенерационные установки (выработка электроэнергии и тепца из извлекаемого шахтного метана):

Высокотемпературные факельные установки закрытого типа с возможностью последующего использования тепиа;
Автоматизированные системы управления Аегазационными, газоотсасывающими насосными и вентиляторными установками; $1500 \mathrm{MM}$

Аегазационные трубы Аиаметром от 300 Ао

06 ору А ван ие, обеспечив а юе е непрерывный мониторинг параметров газовой среды (концентрация метана, концентрация оксиАа углерода, концентрация кислорода, разрежение в трубопроводе, расходи температура метановозАушной смеси) на всем пути её прохождения от скважины (подземная дегазационная сеть) до вакуум-насосной станции;

Аиафрагмы Аиаметром от 80 до 1000 мм Ая измерения каптируемой метановозАушной смеси;

Метамлоконструкции и контейнеры поА технологическое оборудование.

000 «НПП «Завод МАУ» предоставляет услуги

Монтаж, проведение пусконаладочных работ и ввод оборудования в эксплуатацию;

Инструктаж персонала компаний-заказчиков по работе с Аегазационными установками (в том числе выезА специалистов на завод компании Robuschi, г. Парма, Италия).

Сервисное обслуживание, гарантийный и послегарантийный ремонт поставляемого оборудования;

Строительные работы на поверхности поА установку МАУ;

Комплекс работ по бурению Аегазационных скважин, вкиючающий в себя:

- бурение дегазационных скважин;

- герметизацию дегазационных скважин;

-монтаж Аегазационного трубопровода и подкАючение его К модуАьным Аегазационным установкам.

Завод находится на территории Кемеровской области. Общая площадь преАприятия насчитывает

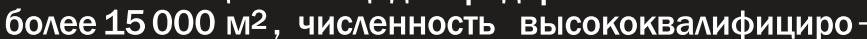
ванных специалистов более 180 человек. 


\section{САДОВ Анатолий Петрович}

Директор управления дегазации и утилизации метана ОАО «СУЭК-Кузбасс», 652518 , г. Ленинск-Кузнецкий, Россия, тел. /факс: +7 (38456) 9-34-20, e-mail: SadovAP@suek.ru

\section{КОСТЕРЕНКО Виктор Николаевич}

Начальник управления противоаварийной устойчивости предприятий $A O$ «СУЭК», канд. физ. -мат. наук, 115054, г. Москва, Россия, тел. / факс: +7 (495) 795-25-38,

e-mail: Kosterenkovn@suek.ru

\section{ТАЙЛАКОВ Олег Владимирович}

Заведующий лабораторией ресурсов и технологий извлечения угольного метана Института угля СО РАН, доктор техн. наук, профессор, 650065, г. Кемерово, Россия, тел. / факс: +7 (3842) 57-50-85, e-mail:Tailakov@uglemetan.ru

\section{УТКАЕВ Евгений Александрович}

Научный сотрудник Института угля СО РАН, канд. техн. наук,

650065, г. Кемерово, Россия, тел. /факс: +7 (3842) 57-50-85, e-mail:utkaev@uglemetan.ru

\section{ЗАСТРЕЛОВ Денис Николаевич}

Старший научный сотрудник Института угля СО РАН, канд. техн. наук, 650065, г. Кемерово, Россия, тел. /факс: +7 (3842) 57-50-85, e-mail: zastrelov@uglemetan.ru

\section{СМыслОВ Алексей Игоревич}

Младший научный сотрудник Института угля СО РАН, 650065, г. Кемерово, Россия, тел. /факс: +7 (3842) 57-50-85, e-mail:smyslov@uglemetan.ru
При разработке угольных месторождений подземным способом выделяется значительное количество метана, который выносится на поверхность системами проветривания и дегазации угольных шахт и оказывает существенное влияние на безопасность ведения горных работ, а также окружающую среду. В статье рассмотрены технологии утилизации низкоконцентрированного вентиляционного метана, представлен опыт разработки проектной документации и внедрения технологического комплекса извлечения и утилизации шахтного метана (ШМ) с низкой и высокой концентрацией. Приведена технологическая схема утилизации метана на примере одной из угольных шахт. Обсуждаются основные показатели работы комплекса в условиях Кузбасса, включая объем утилизированного при этом ШМ, особенности эксплуатации газоутилизационной установки. Обсуждается методологический подход к оценке объемов сокращения выбросов парникового газа (шахтного метана) при его утилизации в газомоторной установке.

Ключевые слова: извлечение шахтного метана, вентиляционный метан, утилизация, газомоторная установка, метановоздушная смесь, выбросы парниковых газов.

Необходимость повышения безопасности и энергоэффективности ведения горных работ, а также смягчения изменения климата предопределяет современные глобальные тенденции развития технологий извлечения и переработки угольного метана. В результате этих мероприятий снижаются его поступление в горные выработки и выбросы в атмосферу. При этом угольный метан является одним из основных парниковых газов, который по степени воздействия на климат превышает углекислый газ в 21 раз, что отмечается, например, в распоряжении Правительства Российской Федерации от 2006 г. о формировании российской системы антропогенных выбросов (кадастров парниковых газов), направленной на оценку объемов антропогенных выбросов и абсорбции парниковых газов. При этом наибольшие объемы эмиссии угольного метана наблюдаются при подземной добыче угля. Поскольку метановоздушная смесь (МВC) при известных концентрациях метана взрывоопасна, проветривание горных выработок и дегазация угольных пластов обязательны для обеспечения безопасного ведения горных работ. Так, шахты Кузбасса ежегодно выбрасывают в атмосферу 1-2 млрд куб. м метана, из них 100-200 млн куб. м составляет дегазационный метан с концентрацией от 3 до 90\% [1]. Вместе с тем в соответствии с «Инструкцией по дегазации угольных шахт» допускается использование MBC на факельных установках при содержании метана не ниже $25 \%$, в качестве топлива: для котельных установок - не ниже $30 \%$, на газомоторных установках - не ниже $25 \%$ и с содержанием не ниже $50 \%$ - для бытовых нужд. Концентрация метана в МBC, извлекаемой газоотсасывающими установками, не превышает 3,5\%. Как правило, такой метан 
не используется, а выбрасывается в атмосферу. При этом существуют различные технологии его утилизации, которые успешно внедряются за рубежом. Так, компаниями Megtec и Biothermica разработаны и внедрены на угольных шахта Австралии и США технологии переработки вентиляционного метана в реверсивных термореакторах для получения тепловой энергии. В 1996 г. в Австралии впервые реализован проект использования вентиляционного метана в качестве дополнительного топлива в двигателях внутреннего сгорания для выработки электроэнергии в 94 газомоторных установках, мощность каждой из которых составляет 1 МВт [2].

В России в основном используется метан, извлекаемый системами дегазации. При этом он применяется в качестве топлива в котельных и контейнерных теплоэлектростанциях, а также для сжигания в факельных установках. Вместе с тем в 2012 г. на шахте «Комсомолец» ОАО «СУЭККузбасс» при поддержке Европейской Седьмой Рамочной Программы (7РП / FP7) выполнен научно-исследовательский проект «CoMeth» (шахтный метан - новые решения использования, сокращения выбросов парниковых газов) $[3,4,5]$. Суть проекта заключалась в демонстрации возможности совместного использования МВС с высокой концентрацией (более 35 \%) и низкой концентрацией (менее 3,5\%) метана в качестве топлива для энергетических установок, а также снижения выбросов парниковых газов. В рамках программы при совместном участии авторов и Pro-2, Anlagentechnik GmbH разработана проектная документация по строительству модифицированного испытательного комплекса для извлечения и утилизации ШМ с низкой и высокой концентрацией. Комплекс оборудова- ния, включающий контейнерную теплоэлектростанцию типа NC 842-TF (КТЭС) и две контейнерные газоутилизационные установки КГУУ-8 (КГУУ), предназначен для выработки электрической и тепловой энергии, а также снижения выбросов парниковых газов в атмосферу.

Комплекс размещен на горном отводе шахты в 15 метрах от скважины с низкой концентрацией метана 1 и в 130 метрах от скважины с высокой концентрацией 2 (рис. 1).

Скважины пробурены с поверхности в выработанное пространство блоков ранее отработанных выемочных участков. При помощи сухих ротационных насосов 7, установленных в КГУУ 5 и 6, метановоздушная смесь извлекается и транспортируется к КТЭС 10. Основные элементы комплекса имеют блочно-модульное исполнение, что повышает его мобильность и сокращает время на монтаж и демонтаж оборудования при смене площадок. Отличительной особенностью данного комплекса является наличие газовых смесителей 11, установленных в КГУУ 6 и КТЭС. Смеситель, установленный в КГУУ, предназначен для поддержания концентрации метана в нагнетательном трубопроводе менее 3,5\%, причем в случае повышения концентрации во всасывающем трубопроводе автоматически открывается клапан для добавления воздуха в систему. Смеситель 11, установленный в КТЭС, предназначен для получения готовой газовоздушной смеси без добавления воздуха. В данный смеситель одновременно подается МВС из скважин с высокой и низкой концентрацией, а также при необходимости добавляется воздух. Готовая горючая смесь поступает для сжигания в двигатель внутреннего сгорания 12, который приводит в действие генератор постоянного тока мощностью 0,4 МВт. Произ-

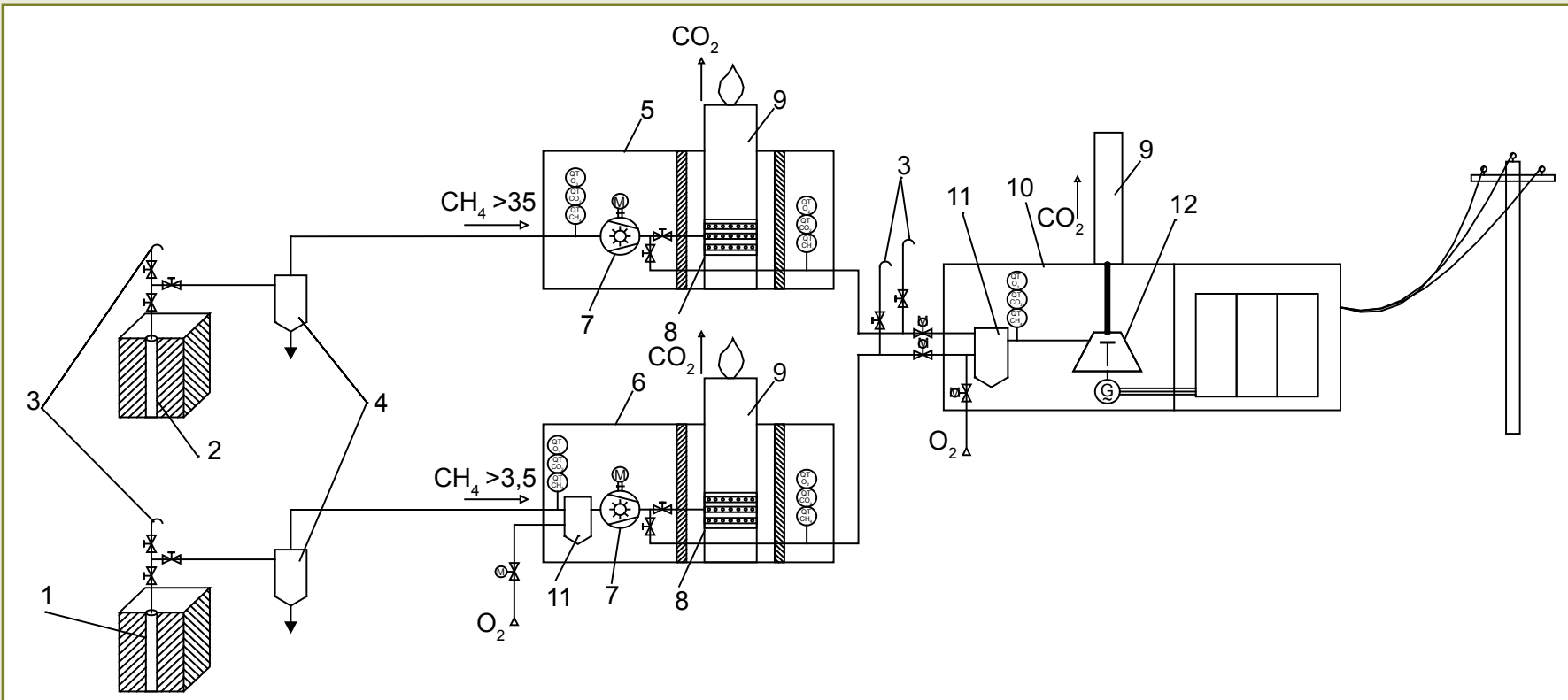

Puс. 1. Технологическая схема утилизации МВС на шахте «Комсомолец»: 1 - скважина с низкой концентрацией метана; 2 - скважина с высокой концентрацией метана; 3 - сбросная свеча; 4 - влагоотделитель; 5 - контейнерная газоутилизационная установка для подачи метановоздушной смеси с высокой концентрацией метана; 6 - контейнерная газоутилизационная установка для подачи метановоздушной смеси с низкой концентрацией метана; 7 - ротационный насос; 8 - камера сжигания; 9 - дымовая труба; 10 - контейнерная теплоэлектростанция; 11 - смеситель; 12 - двигатель внутреннего сгорания

Fig. 1. Process flow schematic of methane-air mixture (MAM) utilization at "Komsomolets" coal mine: 1 - well with low concentration of methane; 2 - well with high concentration of methane; 3-waste gas flare; 4 - moisture separator; 5 - packaged gas recovery plant for methane-air mixture with high concentration of methane feed; 6 - packaged gas recovery plant for methane-air mixture with low concentration of methane feed; 7 - rotary pump; 8 - combustion chamber; 9 - flue gas stack; 10 - packaged heat power-station; 11 - mixing chamber; 12 - internal combustion engine 
Pис. 2. Технологическая схема утилизации МВС на шахте «Комсомолец»: 1 - влагоотделитель; 2 - трубопровод обогрева; 3 - теплоизоляция; 4 - циркуляционный насос; 5 - электроводонагреватель; 6 - блок управления; 7-расширительный бак; 8 - контейнерная газоутилизачионная установка of methane-air mixture (MAM) utilization at "Komsomolets" coal mine: 1 - moisture separator; 2 - heating pipeline; 3 - heat insulation; 4 - circulating pump; 5 - electric water heater; 6 - control unit; 7 - expansion tank; 8 - packaged gas recovery plant
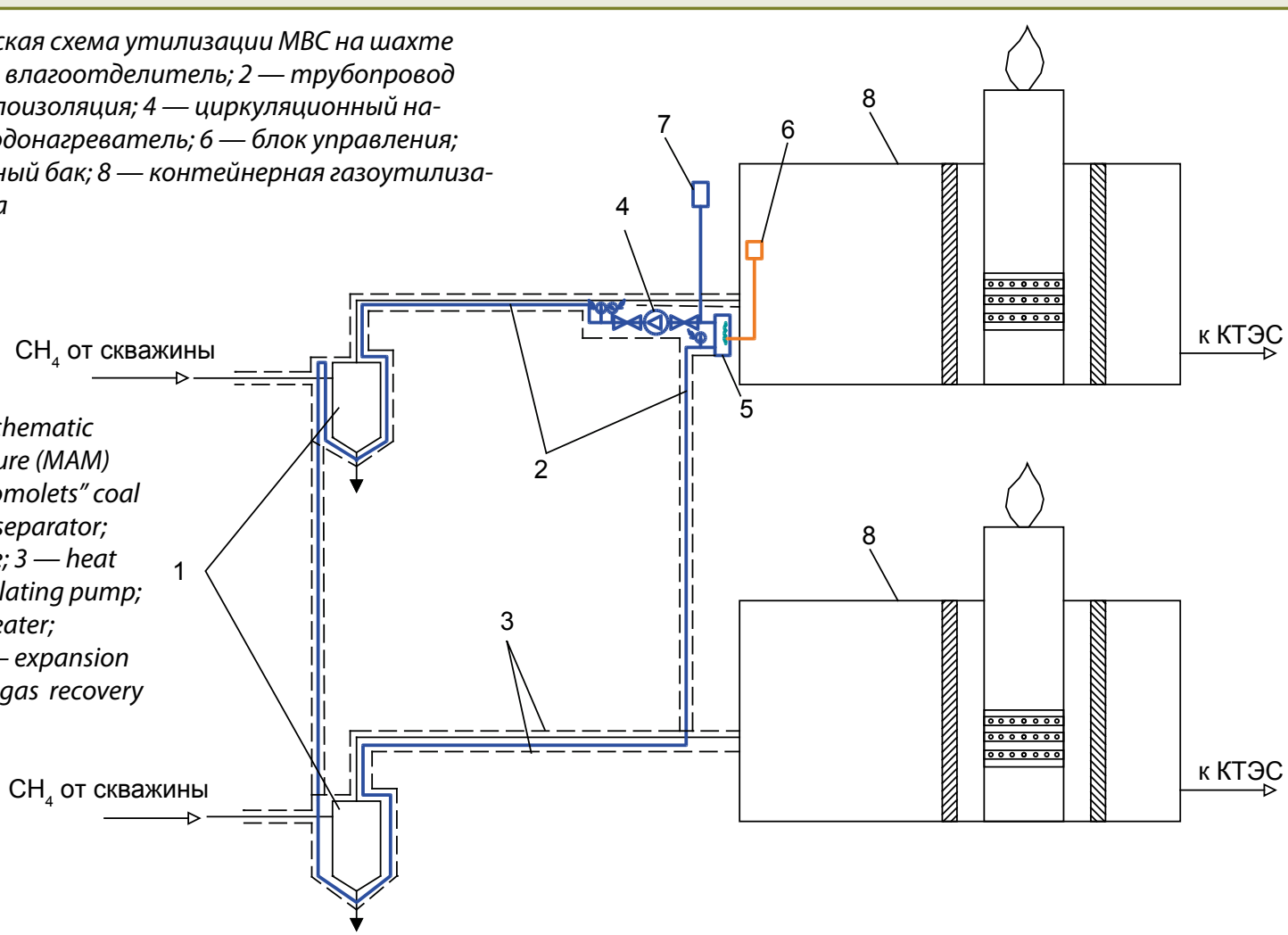

водимая при этом электрическая энергия подается через трансформаторную станцию, расположенную на площадке, для внутреннего потребления или в общую сеть электроснабжения. Тепло охлаждающей жидкости двигателя, формируемое в процессе его эксплуатации, отбирается через пластинчатый теплообменник и используется для обогрева рабочего оборудования, либо отводится в атмосферу.

С учетом опыта эксплуатации ранее установленных утилизационных установок на угольных предприятиях ОАО «СУЭККузбасс» для бесперебойной эксплуатации комплекса и восстановления его после остановок в зимнее время года в составе оборудования предусмотрено применение теплоизоляционного покрытия 3 (рис. 2) и системы спутникового обогрева 2 трубопроводов и влагоотделителей 1.

В качестве теплоносителя в системе

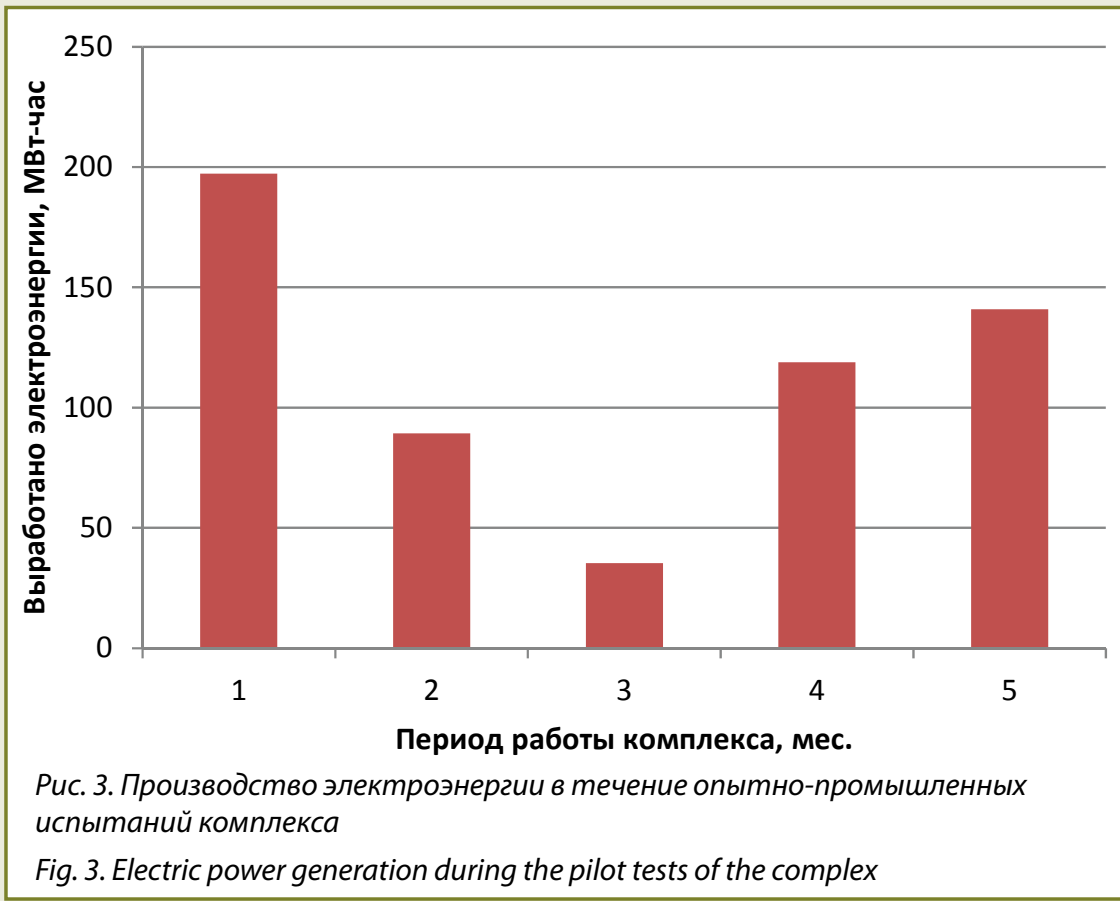
используется незамерзающая жидкость.

Для постоянной циркуляции теплоносителя установлен насос 4 типа ВРН. Резервный насос не предусматривается, так как установлены отсекающие краны, позволяющие отключить его от системы на период ремонта или замены. Для контроля работы системы обогрева, отслеживания режима работы электроводонагревателя 5 и обеспечения функционирования системы аварийной сигнализации, расположенной в блоке управления 6, устанавливаются электроконтактные манометры и термометры.

В течение пяти месяцев опытно-промышленных испытаний комплекс отработал 1999,8 ч. При этом выработано 581,5 МВт.ч электроэнергии (рис. 3). За период работы комплекса переработано 181544 куб. м метана в пересчете на его $100 \%$-ную концентрацию (рис. 4). При этом средняя концентрация метана в рабочей метановоздушной смеси составила $62 \%$ в дополнительной $-2,5 \%$.

В период испытаний происходили аварийные остановки при срабатывании защиты, связанные с недостаточным количеством газа с высокой концентрацией. Для устранения простоев оборудования в дальнейшем была подключена дополнительная скважина с высокой концентрацией. Также в соответствии с установленным регламентом выполнялись плановые остановки, связанные с проведением осмотра и технического обслуживания запорно-регули- 
рующей арматуры и оборудования. Общая продолжительность простоя комплекса составила 1648 ч.

Для оценки объемов выбросов парниковых газов использовалась методология АСМ0008 [6], одобренная Исполнительным комитетом по проектам механизмов чистого развития (CDM Executive board). В соответствии с методологией выбросы по проекту (проектная эмиссия) определены как:

$$
P E_{y}=P E_{M E}+P E_{M D}+P E_{U M^{\prime}}
$$

где: $P E_{M E}$ - проектная эмиссия от использования энергии для каптации и утилизации метана, $\mathrm{TCO}_{2}{ }^{{ }^{1 *}} ; P E_{M D}-$ проектная эмиссия от сжигания метана, $\mathrm{TCO}_{2}$; $P E_{U M}$ - проектная эмиссия от несожженного метана, $\mathrm{TCO}_{2}$ э.

Выбросы по проекту от использования электроэнергии для каптации и утилизации метана рассчитывались по формуле:

$$
P E_{M E}=C O N S_{E L E C, P J} \cdot C E F_{E L E C, P J^{\prime}}
$$

где: $C O N S_{E L E C, P J}$ - дополнительное потребление электроэнергии для каптации, утилизации или сжигания метана, МВт.ч; $C E F_{E L E C, ~ P J}-$ коэффициент углеродной эмиссии для электроэнергии, потребляемой шахтой, $\mathrm{TCO}_{2} / \mathrm{MBT} \cdot 4$.

Выбросы по проекту от сжигания метана в $\mathrm{TCO}_{2}$ э оценивались как:

$$
\begin{aligned}
& P E_{M D}=\left(M D_{F L}+M D_{E L E C}+M D_{H E A T}\right) \times \\
& \times\left(C E F_{\text {CH4 }}+r \times C E F_{\text {NMHC }}\right),
\end{aligned}
$$

где: $r=P C_{\text {NMHC }} / P C_{\text {Сн4 }}-$ соотношение между неметановыми углеводородами и метаном (данные взяты по результатам лабораторного анализа проб метановоздушной смеси); $M D_{F L}-$ количество метана, сжигаемого в высокотемпературных факельных установках, $\mathrm{TCH}_{4} ; M D_{E L E C}$ - количество метана, сжигаемого для производства элект-

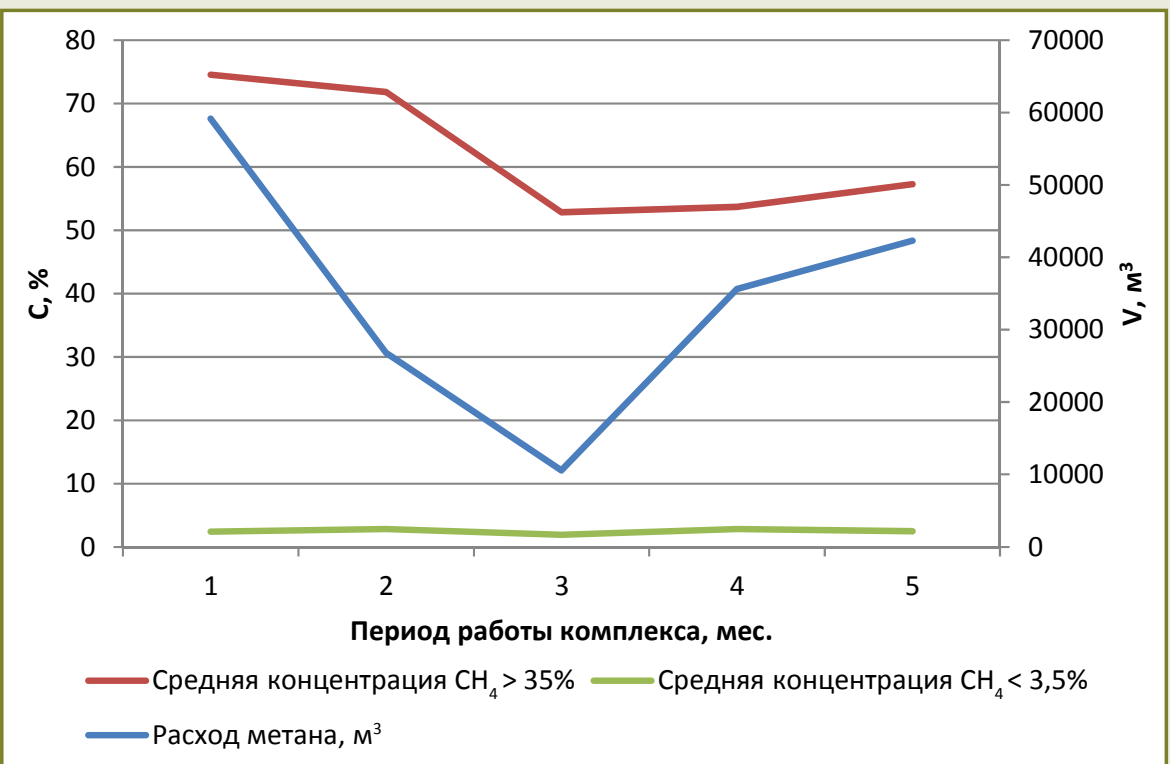

Pис. 4. Объем метана V, переработанного в КТЭС, и средняя концентрация C рабочей и дополнительной $M B C$

Fig. 4. Volume of methane, $V$, processed in the packaged heat-and-power plant and average concentration, $C$, of working and additional MAM

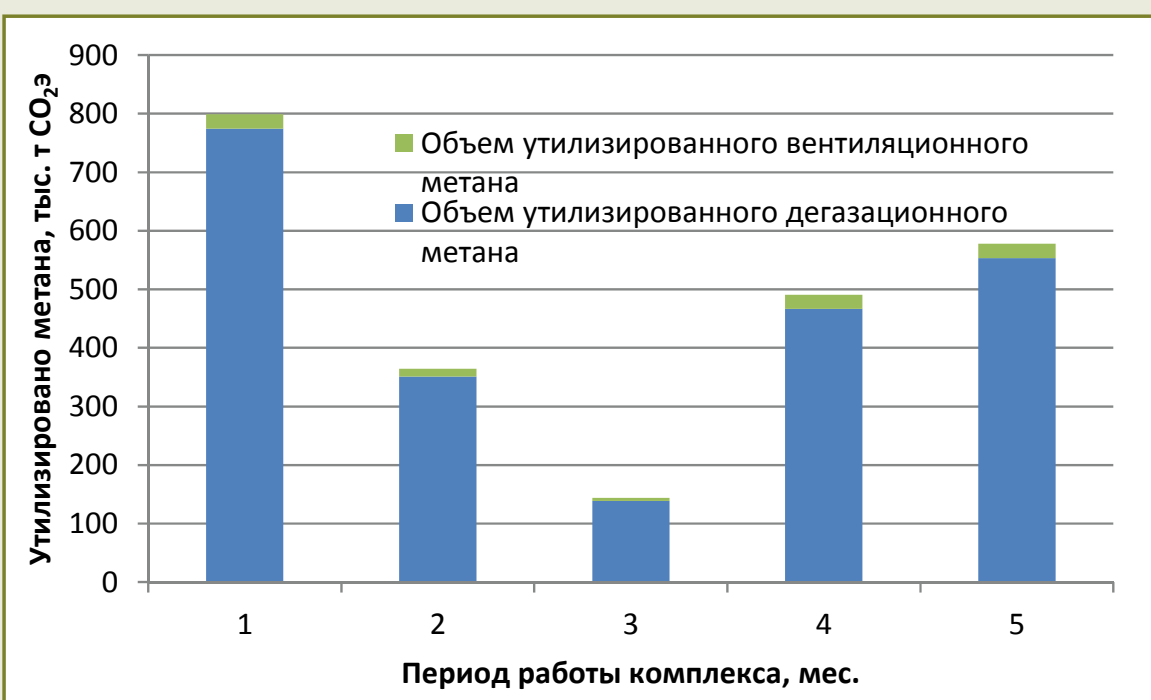

Puc. 5. Утилизация шахтного метана в процессе работы комплекса

Fig. 5. Utilization of coalmine methane in the complex process of operation роэнергии; $M D_{\text {HЕAT }}$ - количество метана, сжигаемого для производства тепла; $C E F_{C H 4}-$ коэффициент выбросов $\mathrm{CO}_{2}$ для сжигаемого метана $\left(2,75 \mathrm{TCO}_{2}{ }^{\ni} / \mathrm{TCH}_{4}\right) ; C E F_{\text {NмHC }}-$ коэффициент выбросов $\mathrm{CO}_{2}$ для сжигаемых неметановых углеводородов, $\mathrm{TCO}_{2}$ э/т; $P c_{C H 4}-$ концентрация метана (по массе) в извлеченном газе, \%; $P c_{N M H C}$ - концентрация не метановыхуглеводородов (по массе) в извлеченном газе, \%.

Метан, не переработанный в результате проектной деятельности, определялся по формуле:

$$
P E_{U M}=\left[G W P_{\mathrm{CH} 4} \cdot \sum M M_{i} \cdot\left(1-E f f_{i}\right)\right]+P E_{\text {Flare, }}
$$

где: $G W P_{\text {сн4 }}$ - потенциал метана в глобальном потеплении, $21 \mathrm{TCO}_{2} э / \mathrm{TCH}_{4} ; i$-утилизация метана (производство тепла и электроэнергии); $M M_{i}$ - замеренный объем метана, направленный на утилизацию в $i, \mathrm{TCH}_{4^{\prime}} ; E f f_{i}$ - эффективность сжигания метана при утилизации в $i, \% ; P E_{\text {Flare }}$ - эмиссия

'Примечание: э-эквивалент.

по проекту от несожженного метана $\mathrm{CH}_{4}$ при сжигании в факеле остаточного газа, $\mathrm{TCO}_{2}$ э.

На основании выполненных расчетов общий объем сокращенных выбросов парниковых газов в результате реализации проекта составил $2375,56 \mathrm{TCO}_{2}$ э. Изменение объемов утилизированного метана в течение работы комплекса представлено на рис. 5.

Проведенные испытания комплекса для извлечения и утилизации шахтного и вентиляционного метана позволили установить, что метановоздушная смесь с концентрацией метана менее 3,5\% может быть эффективно использована совместно с высококонцентрированным метаном в качестве топлива в двигателях внутреннего сгорания для выработки тепловой и электрической энергии на угледобывающих предприятиях Кузбасса. Применение предложенного подхода позволит существенным образом увеличить объемы переработки вентиляционного метана. 


\section{Список литературы}

1. Исламов Д.В., Тайлаков В.О., Застрелов Д.Н. Инвестиционные возможности развития извлечения и использования шахтного метана в угольной промышленности России (на примере Кузбасса). // Горный информационноаналитический бюллетень. 2006. Тематич. прилож. Метан. C. 43-49.

2. [Электронный ресурс]. Режим доступа: http:// www. prospector. su/vyistavki/avstraliya-proizvodstvoelektroenergii-shm-mvs-vut/ (дата обращения 12.10.2015).

3. Садов А.П. Единственные в России // Уголь. 2014. №9. C. 4-5.

4. Мазаник Е. В., Садов А.П., Могилева Е. М., Коликов К.С. Утилизация низкоконцентрированных метановоздушных смесей // Уголь. 2014. №9. С. 86-87.
5. Tailakov O.V., Zastrelov D. N., Utkaev E. A., Smyslov A. I., Kormin A. N. Experience for Coal Mine Methane Utilization to Generate Thermal and Electric Power // Taishan Academic Forum - Project on mine Disaster Prevention and Control Mining 2014. Qingdao, China, 2014. pp. 450-454.

6. «Consolidated baseline methodology for coal bed methane and coal mine methane capture and use for power (electrical or motive) and heat and/or destruction by flaring» (Консолидированная методология расчета базовой линии для извлечения и использования метана угольных пластов и шахтного метана для производства энергии (электрической или двигательной) и тепла и/или сжигания в факеле) // Large-scale Consolidated Methodology Abatement of methane from coal mines / Version 08.0. Sectoral scope (s): 08 and 10. 2014. p. 38. [Электронный ресурс]. Режим доступа: http://cdm. unfccc. int/goto/MPappmeth (дата обращения 12.10.2015).

UDC 622.817.47:662.767.1 @ A.P. Sadov, V.N. Kosterenko, O.V. Tailakov, E.A. Utkaev, D.N. Zastrelov, A.I. Smyslov, 2015

RESURCES

ISSN 0041-5790 (Print) • ISSN 2412-8333 (Online) • Ugol' - Russian Coal Journal, 2015, № 12, pp. 61-65

\section{Title}

\section{EXPERIENCE OF VENT AIR METHANE USE AS SUPPLEMENTARY FUEL FOR INTERNAL-COMBUSTION ENGINES}

DOI: http://dx.doi.org/10.18796/0041-5790-2015-12-61-65

\section{Authors}

Sadov A.P. ${ }^{1}$, Kosterenko V.N. ${ }^{2}$, Tailakov O.V. ${ }^{3}$, Utkaev E.A. ${ }^{3}$, Zastrelov D.N. ${ }^{3}$, Smyslov A.I. ${ }^{3}$

1 "SUEK-Kuzbass" OJSC, Leninsk-Kuznetski, 652518, Russian Federation

2 "SUEK" OJSC, Moscow, 115054, Russian Federation

${ }^{3}$ The Coal Institute of SB RAS, Kemerovo, 650065, Russian Federation

\section{Authors' Information}

Sadov A.P., Director of Methane removal and utilization department, tel.: +7 (38456) 9-34-20, e-mail: SadovAP@suek.ru

Kosterenko V.N., Head of emergency tolerance Department, PhD (Physics and Mathematics), tel.: +7 (495) 795-25-38, e-mail: Kosterenkovn@suek.ru Tailakov O.V., Doctor of Engineering Sciences, Professor, Head of coal bed methane resources and technologies Laboratory, tel.: +7 (3842) 57-50-85, e-mail:Tailakov@uglemetan.ru

Utkaev E.A., PhD (Engineering), research scientist, tel.: +7 (3842) 57-50-85, e-mail: utkaev@uglemetan.ru

Zastrelov D.N., PhD (Engineering), senior research scientist, tel.: +7 (3842) 57-50-85, e-mail: zastrelov@uglemetan.ru

Smyslov A.I., junior research scientist, tel.: +7 (3842) 57-50-85, e-mail: smyslov@uglemetan.ru

\section{Abstract}

During the coal fields development by underground methods the significant amount of methane is released and carried out to the surface by the systems of coal mines venting and degassing, which heavily impacts the mining works and environment safety. The article addresses the technologies of low concentration vent air methane utilization, presents the experience of design documentation development and recovery and utilization of coalmine methane (CM) with low and high concentration. The process flow diagram of methane utilization is explained by the example of one coal mine. The key performance indicators of complex operation in Kuzbass conditions, including the recovered CM volume and specific features of gas recovery plant operation, are discussed. The methodological approach to the assessment of greenhouse gas (coalmine methane) volume reduction during its utilization in the gas-engine unit is presented.

Figures

Fig. 1. Process flow schematic of methane-air mixture (MAM) utilization at "Komsomolets" coal mine: 1 - well with low concentration of methane; 2 - well with high concentration of methane; 3 - waste gas flare; 4 - moisture separator; 5 - packaged gas recovery plant for methane-air mixture with high concentration of methane feed; 6 - packaged gas recovery plant for methane-air mixture with low concentration of methane feed; 7 - rotary pump; 8 - combustion chamber; 9 - flue gas stack; 10 - packaged heat power-station; 11 - mixing chamber; 12 - internal combustion engine
Fig. 2. Process flow schematic of methane-air mixture (MAM) utilization at "Komsomolets" coal mine: 1 - moisture separator; 2 - heating pipeline; 3 - heat insulation; 4 - circulating pump; 5 - electric water heater; 6 - control unit; 7 - expansion tank; 8 - packaged gas recovery plant

Fig. 3. Electric power generation during the pilot tests of the complex

Fig. 4. Volume of methane, $V$, processed in the packaged heat-and-power plant and average concentration, $C$, of working and additional MAM

Fig. 5. Utilization of coalmine methane in the complex process of operation

\section{Keywords}

Coalmine methane recovery, vent air methane, utilization, gas engine plant methane-air mixture, greenhouse gases emissions.

\section{References}

1. Islamov D.V., Tailalov V.O. \& Zastrelov D.N., Investitsionnye vozmozhnosti razvitiya izvlecheniya I ispolzovaniya shaktnjgo metana v ugolnoy promyshlennosti Rossii (na primere Kuzbassa [Investment potential of coalmine methane recovery and utilization development in the coal industry of Russian Federation (by example of Kuzbass)]. Gornyy Informatsionno-Analiticheskiy Byulleten - Mining Information-Analytical Bulletin, 2006, Thematic supplement Methane, pp. 43-49.

2. Available at: http://www.prospector.su/vyistavki/avstraliya-proizvodstvoelektroenergii-shm-mvs-vut/ (accessed 12.10.2015).

3. Sadov A.P. Edinstvennye v Rossii [Unique in Russia]. Ugol' - Russian Coal Journal, 2014, no. 9, pp. 4-5.

4. Mazanik E.V., Sadov A.P., Mogileva E.M., Kolikov K.S. Utilizatsiya nizkokontsentrirovannykh metanovozdushnykh smesey [Utilization of low concentration methane-air mixtures]. Ugol' - Russian Coal Journal, 2014, no. 9, pp. 86-87.

5. Tailakov O.V., Zastrelov D.N., Utkaev E.A., Smyslov A.I., Kormin A.N. Experience for Coal Mine Methane Utilization to Generate Thermal and Electric Power // Taishan Academic Forum - Project on mine Disaster Prevention and Control - Mining 2014. Qingdao, China, 2014. pp. 450-454.

6. Konsolidirovannaya metodologhiya rascheta bazovoy linii dlya izvlecheniyal ispolzovaniya metaa ugolnykh plastov / shakhtnogo metana dlya proizvodstva energii (elektricheskoy ilb dviganelnoy) i tepla i/ili szhiganiya v fakele) [Consolidated baseline methodology for coal bed methane and coal mine methane capture and use for power (electrical or motive) and heat and/or destruction by flaring]. Large-scale Consolidated Methodology Abatement of methane from coal mines, Version 08.0. Sectoral scope(s): 08 and 10. 2014. p. 38. Available at: http: //cdm.unfccc.int/goto/MPappmeth (accessed 12.10.2015). 


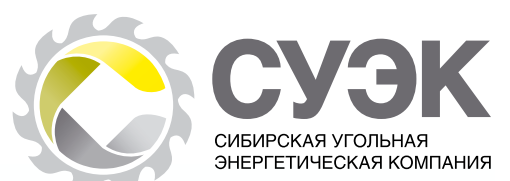

\section{Один из самых современных в стране комплексов по обогащению угля запущен в ОАО «СУЭК-Кузбасс»}
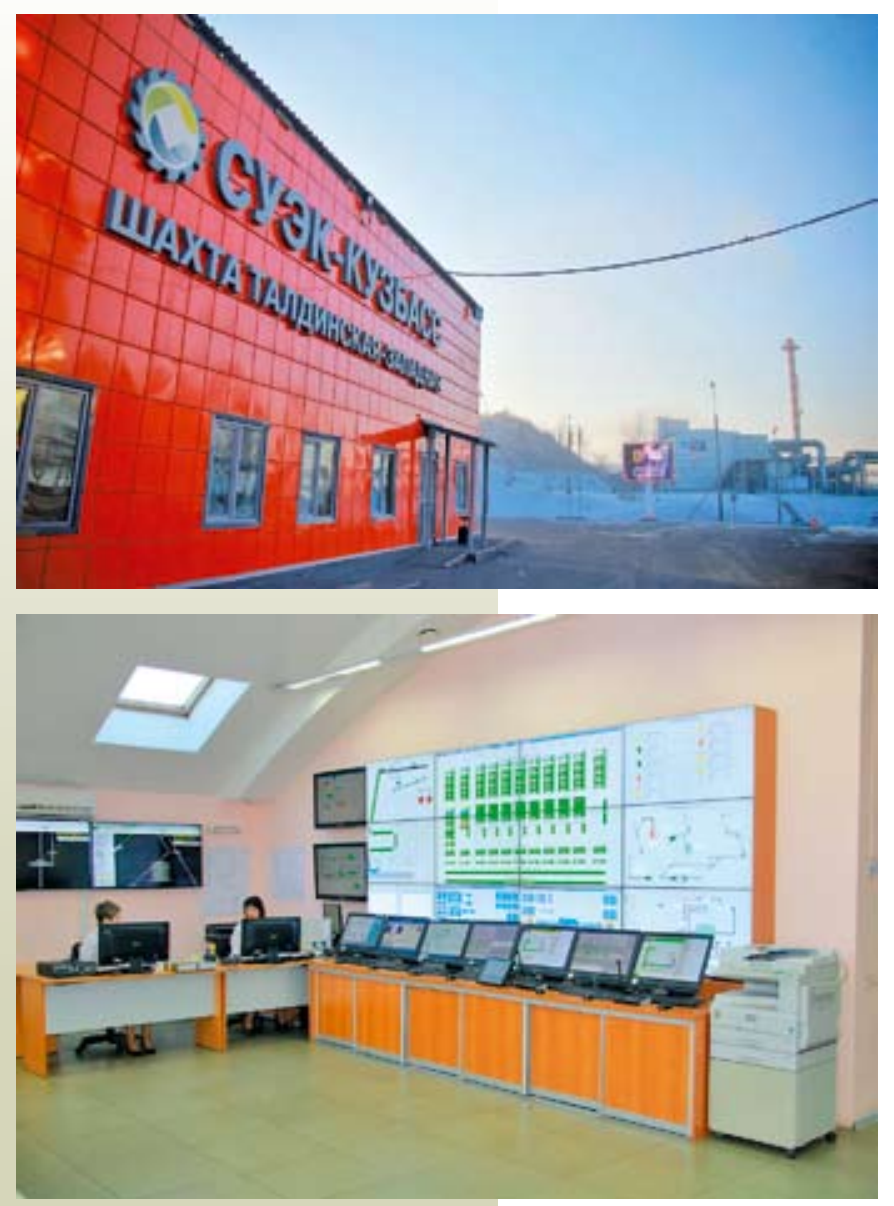

17 ноября 2015 г. губернатор Кемеровской области Аман Тулеев и генеральный директор АО «Сибирская угольная энергетическая компания» Владимир Рашевский торжественно запустили в опытно-промышленную эксплуатацию реконструированный обогатительный модуль шахты «Талдинская-Западная - 1» ОАО «СУЭК-Кузбасс» проектной мощностью 2,7 млн т в год.

Новаторской особенностью модуля является его компактность. Здесь применена целая серия инновационных технологических решений, что позволило отказаться от строительства дополнительного здания, как это предусмотрено в классических схемах. При небольших габаритах модуля он достигает мощности, которую вырабатывают обогатительные фабрики, занимающие минимум в два раза большую площадь.

Еще одна особенность нового промышленного объекта: значительная часть применяемого здесь оборудования - российского производства. При этом контроль и управление технологическим процессом максимально автоматизированы.

В обшей сложности в реализацию проекта $\mathrm{AO}$ «СУЭК» инвестирован 1 млрд руб. Реконструкция была проведена менее чем за один год. При этом создано 104 новых рабочих места.

Данный проект реализован в рамках долгосрочной стратегической программы АО «СУЭК» по развитию обогатительных мощностей, утвержденной советом директоров компании под руководством Андрея Мельниченко в целях наращивания опережающими темпами сбыта на приоритетных азиатских рынках.

В рамках этой программы только в Кузбассе уже реконструированы три обогатительных фабрики ОАО «СУЭК-Кузбасс». В результате доля обогащаемого угля за четыре года на предприятиях ОАО «СУЭК-Кузбасс», с учетом вводимой мощности, возросла в два раза.

Сейчас обогатительный модуль шахты «Талдинская-Западная - 1» выходит на проектный уровень. Его мощности позволяют перерабатывать до 2,7 млн т угля в год с последующей реализацией продукта калорийностью 6500 ккал. При этом модуль может выпускать концентрат экспортного качества двух видов: класса 60-130 мм и класса 0-60 мм, что повышает конкурентоспособность продукции. Энергетический отсев класса 0-6 мм используется для сжигания в кузбасских электростанциях.

Выступая на открытии модуля, губернатор Кемеровской области Аман Тулеев отметил: «Почему мы придаем такое большое значение переработке угля? Прежде всего, обогащенный уголь стоит минимум в два раза дороже, чем рядовой уголь. Прямая экономическая выгода! И давайте честно, если бы мы все эти годы не занимались его переработкой, не взяли бы жёсткий курс на обогащение, то многих наших угольных предприятий в условиях мирового экономического кризиса уже бы просто не было!»

«Новая фабрика - пример того, что в нынешней кризисной ситуации нужны особенные, нестандартные технические и инвестиционные решения, - подчеркнул в своем выступлении генеральный директор АО «СУЭК» Владимир Рашевский. Приходится включать смекалку и мозги. Придумывать, как меньшими ресурсами добиться такой же эффрективности и надежности». 


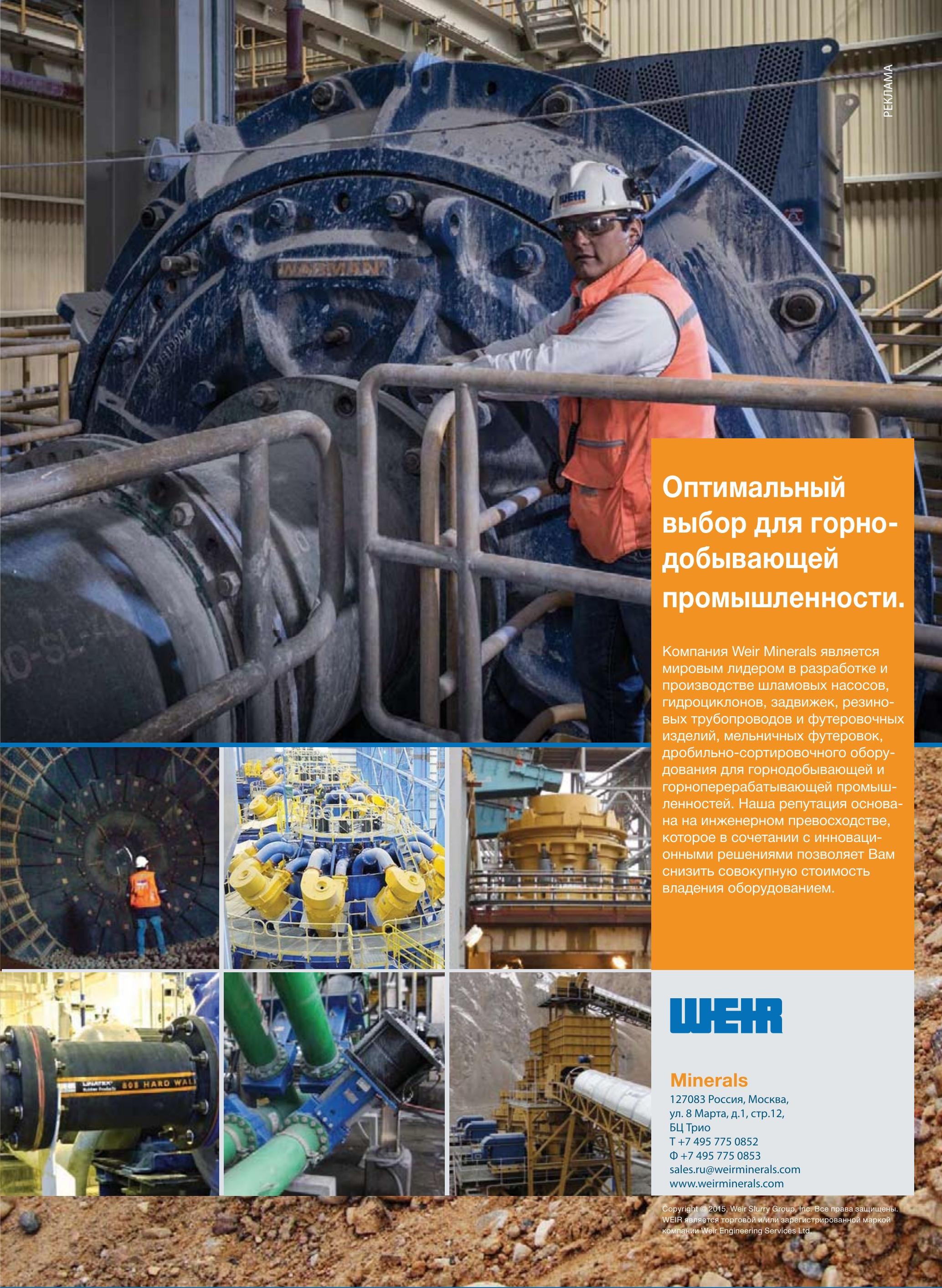




\section{К вопросу о современных технологиях переработки и обогащения угля}

DOI: http://dx. doi. org/10.18796/0041-5790-2015-12-68-71

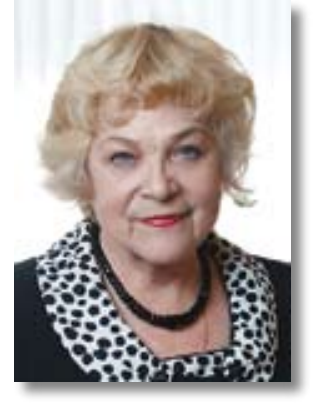

\begin{abstract}
АНТИПЕНКО
Лина Александровна

Научный руководитель

ООО «Сибнииуглеобогащение», доктор техн. наук, профессор, 653000, г. Прокопьевск, Россия, тел.: +7 (3846) 611-858
\end{abstract}

Рассматривается возможность создания автоматизированных предприятий нового поколения с использованием качественно новых технических решений переработки и обогащения угля. ООО «Сибнииуглеобогащение» разработаны технологические схемы для обогащения коксующихся и энергетических марок углей, предусматривающие оборудование для флотации, обезвоживания и сгущения шламов, позволяющее получить высококачественные продукты обогащения с минимальной влагой, не требующие термической сушки. Предлагается архитектурно-строительная конструкция здания главного корпуса обогатительной фабрики - павильонная, с использованием этажерок и антресолей.

Ключевые слова: обогатительная фабрика, переработка, обогащение, технологические схемы для обогащения коксового угля, технологические схемы для обогащения энергетического угля, флотация, обезвоживание, шламы

Согласно прогнозу Международного энергетического агентства, в середине нынешнего столетия в мировом топливно-энергетическом балансе будет преобладать уголь, запасов которого хватит на шесть веков, причем на долю угля приходится около $90 \%$ энергетического потенциала полезных ископаемых органического происхождения, пригодных для промышленной разработки. Мировое потребление энергоресурсов возрастет в 1,4 разадо 17,3 млрд т условного топлива, в том числе угля до 5 млрд т условного топлива (в 1,5 раза).

Современные технологии развития угольной энергетики обусловлены технологиями переработки углей. В настоящее время технологии переработки углей условно подразделяют на два вида: традиционные и инновационные технологии.

К традиционным относятся широко распространенные - сортировка, агломерирование, обогащение, сжигание, полукоксование, коксование. Менее распространены, как относительно новые, газификация, сульфирование, терморастворение, получение водоугольных топлив.
И второй вид, новые - инновационные, то есть требующие определенных инвестиций для их промышленного использования: обогащение до зольности 0,15\% с получением заменителя флотского мазута, получение спецсорбентов, получение новых форм чистого углерода (фуллерены и карбин), получение углеродных материалов (волокна, композиты). Эти технологии в процессе переработки углей предусматривают изменение их химического состава и входят в компетенцию углехимиков.

ООО «Сибнииуглеобогащение» занимается вопросами механической переработки углей, т.е. углеобогащением без изменения их химического состава. Институт входит в состав AО «СУЭК» и по своему профилю решает весь комплекс вопросов, связанных с углеобогащением, качеством продуктов обогащения, разработкой проектов реконструкций и новых угледобывающих и углеобогатительных предприятий.

Отметим, что Россия является одним из мировых лидеров по производству угля. По состоянию на 01.01.2015 в угольной промышленности действуют 193 угледобывающих предприятия, которыми за 2014 г. добыто 358,2 млн т угля. Переработка угля осуществляется на 61 фабрике и установке, объем переработки - 171,6 млн т.

Одной из самых крупных угледобывающих компаний страны является $\mathrm{AO}$ «СУЭК». Анализ деятельности предприятий $\mathrm{AO}$ «СУЭК» позволил запланировать увеличение добычи угля и особенно выпуска продукции обогатительных фабрик. В будущем предполагаются строительство и совершенствование углеобогатительных фабрик производительностью 12-14 млн т в год. Чтобы добиться этих целей, было предложено увеличить объем инвестиций. Увеличение добычи угля и выпуска обогащенного угля приведет к увеличению объемов товарной продукции экспортного качества.

В самом крупном угольном регионе страны - в Кузбассе (здесь объем добычи за 2014 г. составил 210,8 млн т) в эксплуатации находятся 49 обогатительных фабрик и установок, объем переработки которых за 2014 г. составил 105,21 млн т. Требования к качеству угольной продукции со стороны потребителей на внутреннем и мировом рынках постоянно возрастают. В условиях современного отечественного рынка максимальная доходность от производства и продажи угольной продукции обеспечивается за счет экспорта угля.

В планируемой перспективе актуальной задачей является обеспечение требуемых рынком высоких качественных характеристик конкурентоспособной угольной продукции. Решение этой задачи возможно путем обогащения добываемых углей.

На основе детального изучения опыта эксплуатации обогатительных фабрик Кузнецкого бассейна возможно созда- 
ние автоматизированного предприятия нового поколения в области углеобогащения с использованием качественно новых технических решений, позволяющих снизить затраты при освоении новых производственных мощностей.

Создание автоматизированного предприятия нового поколения в области обогащения основано на системе автоматизированного управления (САУ).

Объектами управления являются:

- комплекс технического оборудования, агрегатов и поточно-транспортных систем производства для приема и подготовки к обогащению рядовых углей, транспортировки, складирования и выгрузки из штабелей рядовых углей и концентратов, транспортировки и погрузки концентратов в железнодорожные вагоны, транспортировки, складирования и отгрузки породы;

— комплекс технологического оборудования и агрегатов для реализации технологического цикла обогащения рядовых углей - классификации, обогащения в тяжелых средах или отсадки, флотации, фильтрации и обезвоживания продуктов обогащения, транспортировки шламов, фильтратов, фугатов;

- вспомогательное оборудование и системы бесперебойного энергоснабжения, аспирации и дымоудаления, откачки дренажных вод и др.

Создание систем автоматического управления производственным комплексом обогатительной фабрики позволяет сократить сроки вывода ОФ на проектную мощность, повысить производительность, сократить затраты на текущее обслуживание и ремонт технологического оборудования.

До последнего времени в зависимости от пространственного расположения оборудования применялись следующие варианты компоновочных решений схем: многопролетный, многоэтажный, павильонный и антресольно-павильонный.
При высотной схеме компоновки увеличивается высота зданий и усложняется проведение ремонтных работ. Многоэтажность требует значительного количества обслуживающего персонала, что увеличивает себестоимость процесса обогащения.

Павильонная схема компоновки оборудования обеспечивает удобное, рациональное опробование и контроль работы оборудования. Недостатком павильонной компоновки является увеличение площади производственных зданий.

Для проектирования и строительства 15 обогатительных фабрик применены безэтажные схемы компоновки. При этом в здании отсутствуют межэтажные перекрытия. Оборудование монтируется на металлоконструкциях. Обслуживающие площадки изготавливаются из просеченного железа. Преимуществами являются отсутствие межэтажных бетонных перекрытий, простота обслуживания и ремонта оборудования, возможность применения оборудования большего размера.

Сложившаяся практика обогащения коксующихся углей сводится в основном к использованию для переработки углей трудной и очень трудной обогатимости тяжелых сред и для углей легкой и средней обогатимости - отсадочных машин.

Исследование новейших технологий позволяет усовершенствовать сложившуюся структуру обогатительной фабрики, ее компоновочные решения и создать по форме и содержанию предприятие нового поколения.

В технологической схеме обогатительной фабрики нового поколения необходимо увеличить глубину обогащения углей до нуля (мм).

Институтом «Сибнииуглеобогащение» предлагается принципиально новая схема обогащения коксующихся углей (рис. 1).

Эта технологическая схема включает следующие основные операции: подготовку углей для обогащения; обо-

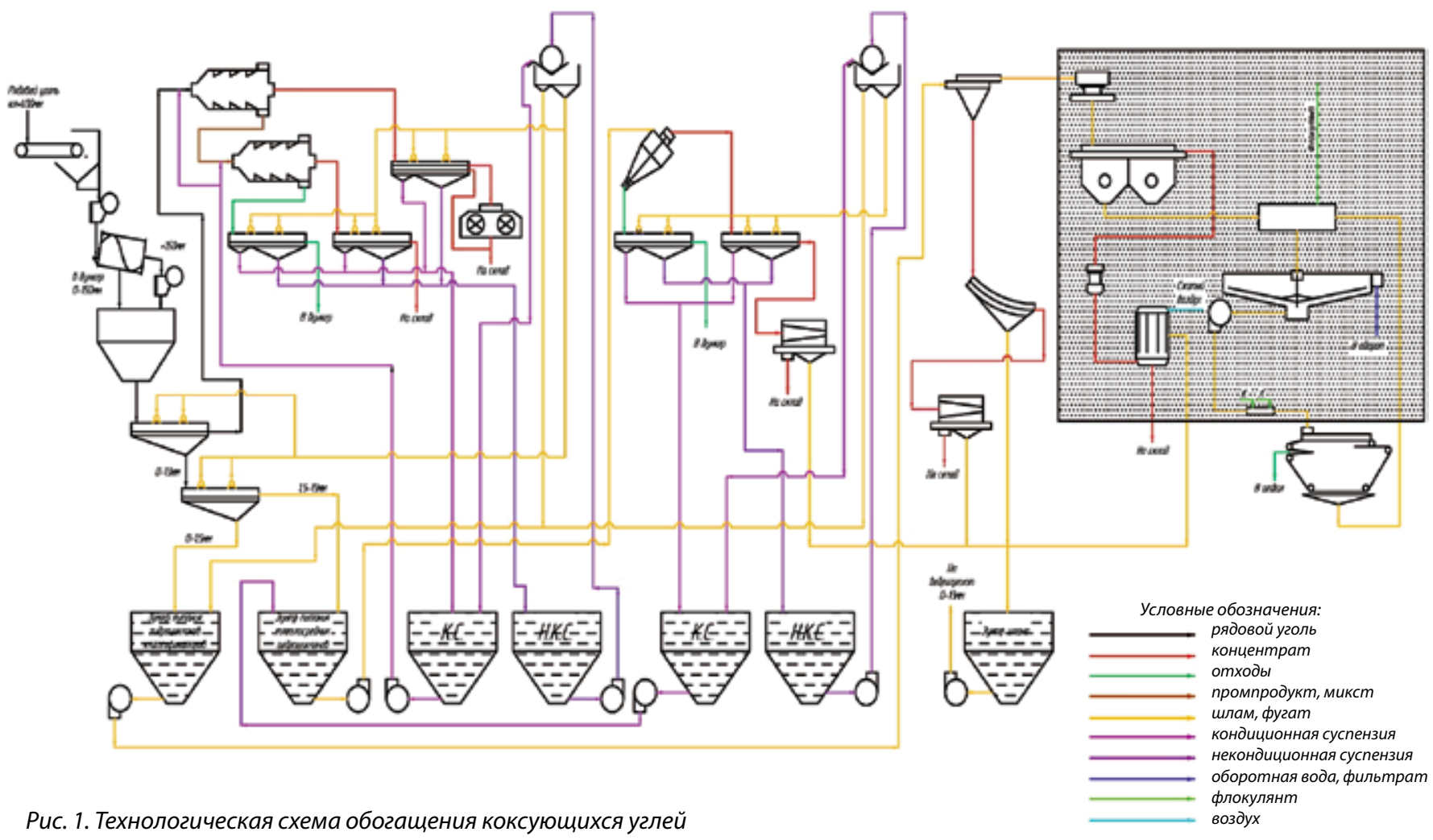




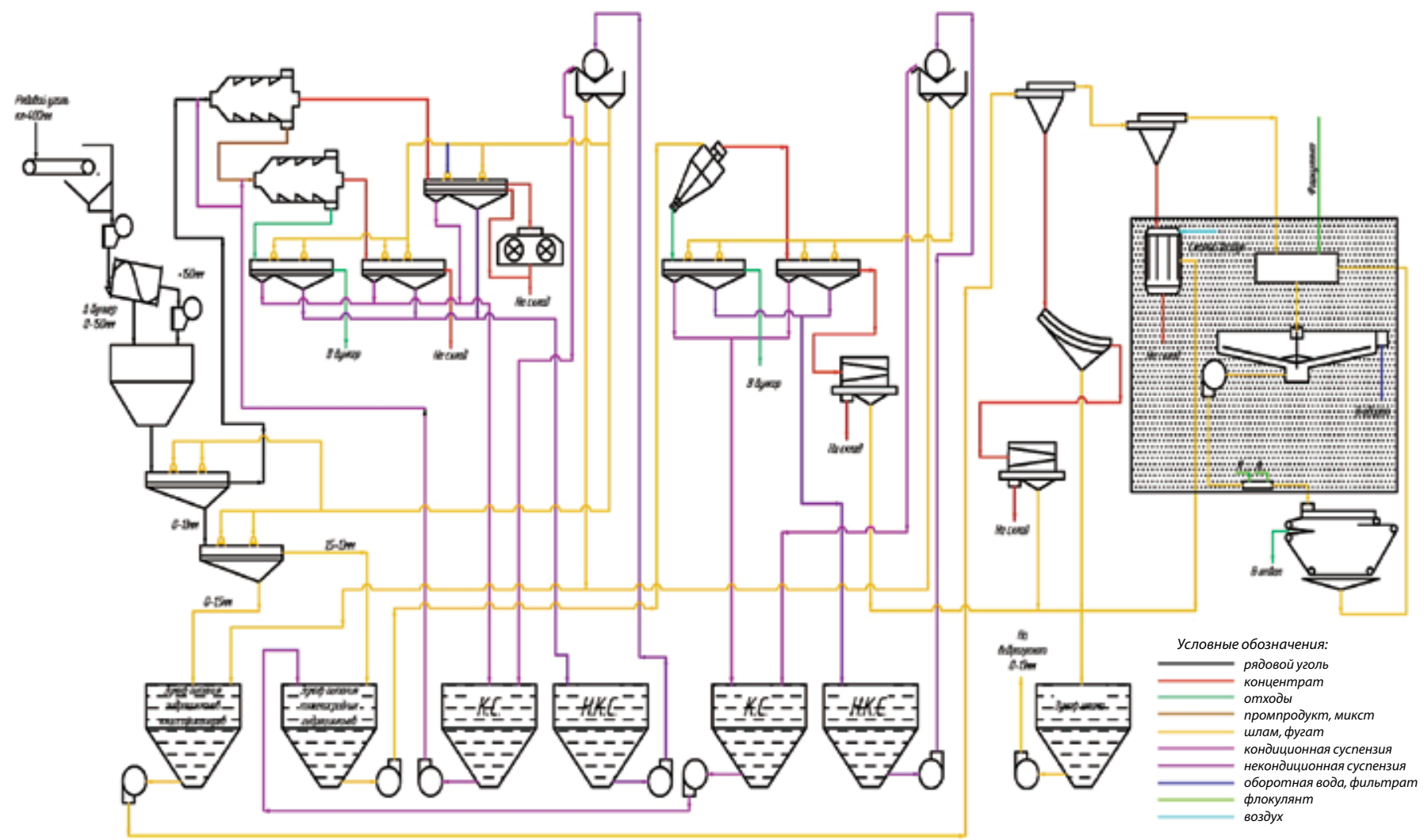

Puс. 2. Технологическая схема обогащения энергетических углей

гащение крупного угля в тяжелосредных сепараторах; обогащение мелкого угля в тяжелосредных циклонах; обогащение тонкого шлама (менее 0,30 мм) в пневматических флотомашинах «Пневмофлот» (разработка «Сибнииуглеобогащение»; обезвоживание флотационного концентрата в патронных фильтрах 6ПТК-10 (разработка Института «Сибнииуглеобогащение»); сгущение шламовых вод в радиальном сгустителе ЦГ-30 перед прессованием шлама (разработка Института «Сибнииуглеобогащение»); обезвоживание отходов флотации в фильтр-прессах; напольный укрытый склад для концентрата с фронтальным погрузчиком без тоннеля.

Применение подобной схемы позволит исключить термическую сушку, получать влажность конечного продукта в пределах норм, обусловленных потребительскими ГОСТами.

Обычно требования к качеству энергетических углей были ниже, чем к качеству коксующихся. Поэтому обогащались в основном крупные (сортовые) классы углей, которые использовались в быту или в топках коммунальных и промышленных котельных. Нижний предел обогащения достигал 6 мм, водно-шламовое хозяйство фабрик было сравнительно простым. Однако в последние годы требования к качеству энергетических углей ожесточились. Технологические схемы и компоновочные решения изменились и стали соответствовать параметрам технологии и техники обогащения применительно к коксующимся углям.

Институтом «Сибнииуглеобогащение» разработана принципиально новая схема обогащения энергетических углей (рис. 2).

В здании главного корпуса обогатительной фабрики, используя имеющийся опыт, следует располагать новое современное оборудование, включая фильтр-прессовое отделение. Водно-шламовая схема должна быть замкнута, без наружных илонакопителей. Каркас здания - павильонного типа с использованием этажерок и антресолей.

В технологических схемах необходимо применять оборудование как отечественного, так и импортного производства.

\section{Выводы}

1. Первостепенная задача - создать автоматизированное предприятие нового поколения с использованием качественно новых технических решений, позволяющих снизить затраты при освоении новых производственных мощностей.

2. Институтом «Сибнииуглеобогащение» разработаны технологические схемы для обогащения коксующихся и энергетических марок углей, предусматривающие оборудование для флотации, обезвоживания и сгущения шламов, позволяющее получить высококачественные продукты обогащения с минимальной влагой, не требующие термической сушки.

Это флотационные машины пневматического типа «Пневмофлот» и механического - «Флотомодерн», патронные фильтры под давлением 6ПТК-10 для обезвоживания концентрата флотации и шламов, новые флотационные реагенты и флокулянты, современные дозаторы реагентов, пеногасители, радиальные сгустители, укрытые склады готовой продукции и др.

Флотационные машины, патронный фильтр под давлением прошли испытания на обогатительных фабриках Кузнецкого бассейна. Получены весьма положительные результаты, которые были представлены на Международ- 
ных конгрессах в Польше, КНР. В настоящее время требуется разработка рабочей документации на изготовление опытных образцов. Получены патенты на изобретения.

3. Предлагается архитектурно-строительная конструкция здания главного корпуса - павильонная с использованием этажерок и антресолей.

4. Компоновочные решения и использование нового современного оборудования позволят получать высококачественные продукты обогащения, удовлетворяющие требованиям рынка и потребительским стандартам.
5. Исключить из технологии обогащения спиральные сепараторы и гидросайзеры. Для обогащения шламов рекомендуется применять тяжелосредные гидроциклоны.

6. Разработать новые методы сушки мелкого угля и шлама.

7. Использовать и внедрить опыт подачи пара на гипербарфильтры (опыт Германии, Bogoba $\mathrm{GmbH}$ ).

8. Производить осушение шлама с помощью керамических шариков (США).

UDC 622.7.012.7 @ L. A. Antipenko, 2015

COAL PREPARATION

ISSN $0041-5790$ (Print) • ISSN 2412-8333 (Online) • Ugol' — Russian Coal Journal, 2015, № 12, pp. 68-71

Title

ON THE ISSUE OF ADVANCED COAL PROCESSING AND BENEFICIATION TECHNOLOGIES

DOI: http://dx. doi. org/10.18796/0041-5790-2015-12-68-71

Author

Antipenko L. A. ${ }^{1}$

'Sibniiugleobogascheniye LLC, Prokopyevsk, 653000, Russian Federation

Authors' Information

Antipenko L.A., Doctor of Engineering Sciences, Professor, Scientific Supervisor, tel.: +7 (3846) 611-858

Abstract

The possibility of creating a new generation of automated enterprises through the use of a qualitatively new technical coal processing and beneficiation solutions is discussed. Sibniiugleobogascheniye LLC has developed process flow diagrams for coking and power-plant coal beneficiation, which envisage equipment for sludge flotation, dewatering and thickening, allowing the production of high quality products with minimal moisture content, which do not require thermal drying. An architectural design of the main building of the concentrator (pavilion with mezzanines and shelving units) is suggested.

Keywords

Concentrator, Processing, Beneficiation, Process Flow Diagrams for Coking Coal Beneficiation, Process Flow Diagrams for Power Plant Coal Beneficiation, Flotation, Dewatering, Sludge.

\section{Бригада Дмитрия Година шахты «Талдинская-Западная-1» первой в России добыла три миллиона тонн угля}

\begin{abstract}
Очистная бригада Дмитрия Година шахты «Талдинская-Западная-1» ОАО «СУЭК-Кузбасс» добыла в начале ноября трехмиллионную тонну угля с начала года. Это первый коллектив в угольной отрасли страны, сумевший в 2015 г. достичь такого рубежа.
\end{abstract}

Успешная работа очистного коллектива позволила шахте «Талдинская-Западная-1» первой в компании выполнить годовой производственный план, выдав на-гора 3,2 млн т угля.

Весь уголь бригадой добыт из лавы № 66-06 с вынимаемой мощностью пласта 4,6 м. Длина лавы составляет 300 м. Забой оборудован 175 секциями крепи DBT 220/480, самым современным и высокопроизводительным комбайном 6LS-7, лавным конвейером и перегружателем SH-PF-6/1142 DBT.

Масштабная программа технического перевооружения шахты «Талдинская-Западная-1» началась в 2011 г. За последние 5 лет Сибирской угольной энергетической компанией в предприятие инвестировано более 8 млрд руб., в том числе около 400 млн руб. - непосредственно в программы промышленной безопасности. Проектная мощность предприятия за счет этого была увеличена с 2,9 млн т до 4 млн т в год.

Напомним, что именно этому коллективупринадлежит всероссийский рекорд по добыче угля вмесяц из одного очистного забоя, установленный в марте 2013 г. Тогда на-гора было выдано 1007 тыс. т.

Бригада Дмитрия Година восемь раз становились победителями еженедельного производственного соревнования «День повышенной добычи» и по этому показателю также является лидером компании.

Наша справка.

АО «СУЭК» —однаиз ведущихугледобывающихкомпаний мира, крупнейщий в России производитель угля, крупнейший поставщик на внутренний рынок и на экспорт. Добывающие, перерабатывающие, транспортные и сервисные предприятия СУЭК расположены в семи регионах России. На предприятиях СУЭК работают более 33 тыс. человек. Основной акционер - Андрей Мельниченко (92,2%). 


\section{Пресс-служба АО ХК «СДС-Уголь» информирует \\ Обогатители ОФ «Прокопьевскуголь» отметили тройной юбилей}

Тройной юбилей отметили обогатители объединения ООО ОФ «Прокопьевскуголь» (АО ХК «СДС») - 10 лет со дня образования общества, 60 лет обогатительной фабрики «Зиминка» и 65-летний юбилей ОФ «Красногорская». С момента запуска предприятий обогатителями переработано более 210 млн т угля.

В 2005 г. фабрики «Зиминка» и «Красногорская» объединились в ООО ОФ «Прокопьевскуголь». В 2010 г. Холдинговая компания «Сибирский Деловой Союз» приступила к комплексной модернизации обогатительных фабрик, предусматривающей капитальный ремонт основных фондов и внедрение современного высокотехнологичного оборудования. Инвестиции в техническое перевооружение фабрики составляют более 980 млн руб.

В результате пятилетних вложений в производство и промышленную безопасность объем выпускаемой продукции вырос на 50\%: с 1,090 млн т в 2010 г. до 1,577 млн т в 2015 г.

Модернизированы практически все этапы производства. Модифицирован процесс переработки: внедрено обогащение углей мелких классов (0,2-1 мм) на спиральных сепараторах. Параллельно на предприятиях установлены современные центрифуги для обезвоживания концентрата. Среди главных технических новшеств - автоматическое управление процессом флотации. Как итог: вырос выход концентрата, снижены потери с отходами и затраты на флотореагент.

Улучшены социально-бытовые условия работников: проведен капитальный ремонт административно-бытовых комбинатов. Отремонтированы галереи, установлены пластиковые окна. Тем самым удалось создать более комфортные по температурному режиму условия труда для работников.

На торжественном мероприятии, посвященном тройному юбилею более 100 обогатителей, пенсионеров и ветеранов ООО ОФ «Прокопьевскуголь»

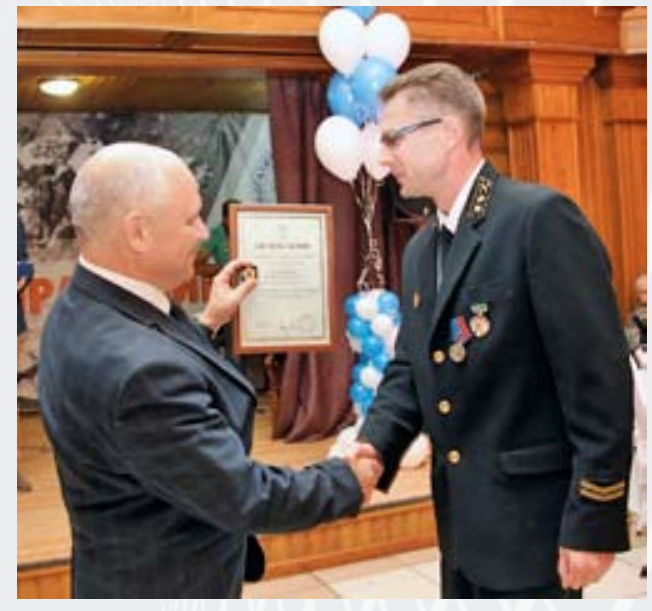

были награждены денежными премиями, ведомственными, региональными и корпоративными наградами.

Наша справка.

АО ХК «СДС-Уголь» входит в тройку лидеров отрасли в России. По итогам 2014 года предприятия компании ХК «СДС-Уголь» добыли 28,5 млн т угля. 88 \% добываемого угля поставляется на экспорт. АО ХК «СДС-Уголь» является отраслевым холдингом АО ХК «Сибирский Деловой Союз». Взонуответственностикомпаниивходят 16 предприятий, расположенных на территории Кемеровской области.

Пресс-служба АО ХК «СДС-Уголь» информирует

\section{ОФ «Зиминка» - новый рекорд обогатителей}

Коллектив обогатительной фабрики "Зиминка» (входит в состав ООО ОФ «Прокопьевскуголь») по итогам октября 2015 2. установил рекорд по переработке и обогащении угля полным ииклом, перевыполнив план на $16 \%$. При плане 126,6 тыс. $\mathbf{m}$ фактически переработано 146,8 тыс. $\mathrm{m}$. Это лучший результат за всю историю предприятий ООО «ОФ «Прокопьевскуголь».

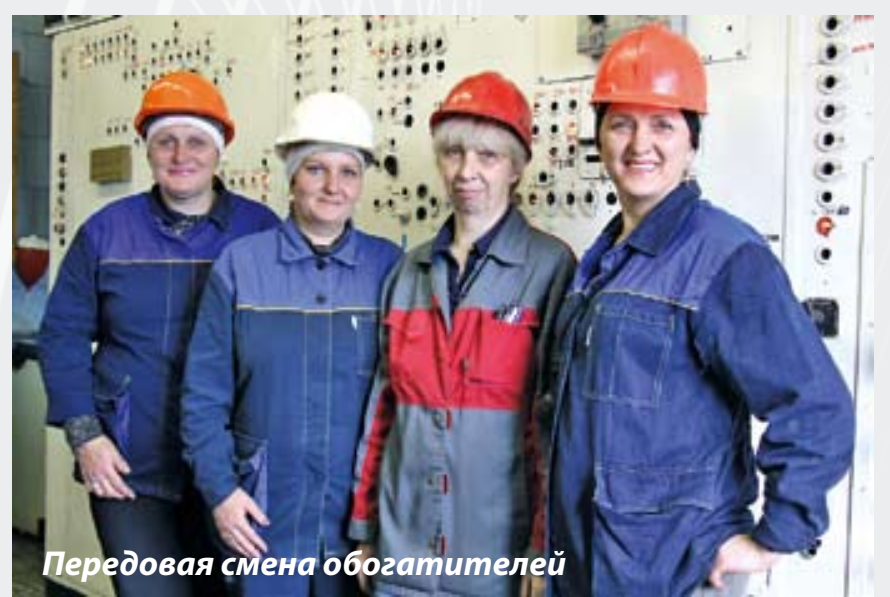

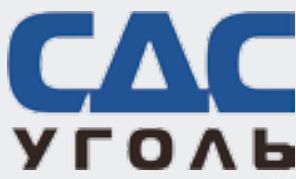

Рекордные показатели - закономерный результат слаженной и грамотной работы коллектива фабрики «Зиминка». Стоит отметить, что по итогам октября особо отличилась смена №3 под руководством начальника Марии Ивановны Корниенко, обогатители которой переработали 42,8 тыс. т рядового угля. Именно эта смена продемонстрировала лучший результат по итогам мая 2015 г., когда был установлен предыдущий рекорд предприятия по переработке и обогащению угля полным циклом - 142 тыс. т угля.

«В очередной раз обогатители ОФ «Зиминка» продемонстрировали высокий профессионализм и умение ударно трудиться, - отметил Владимир Моховиков, генеральный директор ООО ОФ «Прокопьевскуголь». Отличные производственные показатели - это в первую очередь заслуга всего нашего коллектива, стабильных поставок сырья угледобывающими предприятиями компании "СДС-Уголь», а также реализации инвестиционной программы «Сибирского Делового Союза», в рамках которой мы произвели реконструкцию производства».

Всего до конца года обогатители фабрики «Зиминка» планируют переработать 1,48 млн т рядовых углей. 


\title{
Образование отходов производства от предприятий угольной отрасли на территории Кемеровской области
}

\author{
DOI: http://dx. doi. org/10.18796/0041-5790-2015-12-73-76
}

Рассмотрены вопросы обращения с отходами предприятий по добыче полезных ископаемых на территории Кемеровской области, которые при накоплении негативно воздействуют на окружающую среду. Анализ данных по объему образования, использования и размещения отходов производства угледобывающими предприятиями свидетельствует о том, что угольная промышленность является одной из основных отраслей, которые оказывают мощное техногенное воздействие на окружающую среду. Специфичным для угледобычи характером воздействия на природную среду является использование земельных ресурсов, при котором происходит разрушение естественных природных ландшафтов - уничтожаются не только растительный, почвенный покров, почвообразующие слои литосферы, но и геологический фундамент ландшафта на сотни метров в глубину. Это приводит к изъятию из хозяйственного оборота продуктивных земельных площадей. В целях совершенствования единой государственной политики в области обращения с отходами производства и потребления на территории Кемеровской области разработано и действует Положение о порядке ведения регионального кадастра отходов. Проблема утилизации и размещения отходов производства является актуальной не только для Кузбасса, но и для других регионов страны, ведущих разработку полезных ископаемых.

Ключевые слова: добыча, угледобывающее производство, образование отходов, класс опасности отхода.

Кемеровская область является регионом с многоотраслевым хозяйством и высокой концентрацией сырьевых и перерабатывающихпроизводств, что обусловливаетобразование в больших объемах отходов производства и потребления. В связи с этим для Кузбасса актуальными остаются проблемы обращения с отходами на территории области и их негативного воздействия на окружающую среду $[1,2,3,4,5]$.

По данным государственной статистической отчетности, на территории области за 2014 г. образовалось 2640560,661 тыс. т отходов производства и потребления (рис. 1), из них:

- использовано - 1064941,364 тыс. т;

- обезврежено - 347,982 тыс. т.;

размещено на объектах - 1580254,302 тыс. т,

в том числе на собственных объектах:

- на хранение - 1577259,817 тыс. т;

- на захоронение - 2994,459 тыс. т.

За период с 2009 г. наметилась устойчивая тенденция увеличения общего количества отходов. В целом за пять лет объем образования отходов увеличился на 876,142 млн т. Незначительный спад образования отходов производства и потребления наблюдается в 2014 г., на 20,72 млн т.

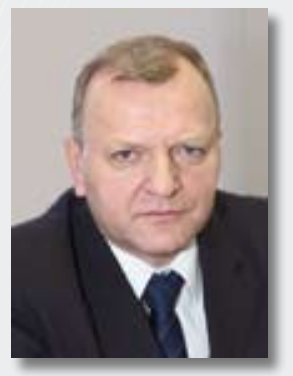

ЕФИМОВ Виктор Иванович

Профессор НИТУ «МИСиС», доктор техн. наук, 119049, г. Москва, Россия, e-mail:v.efimov@sds-ugol.ru

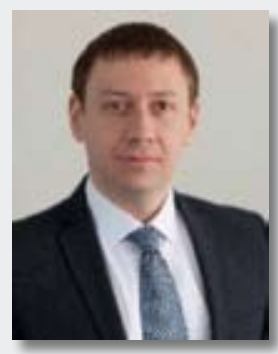

\section{СИДОРОВ}

Роман Владимирович

Директор 000 «Сибирский

Институт Горного Дела», 653066, г. Кемерово, Россия, e-mail: r.sidorov@sds-ugol.ru

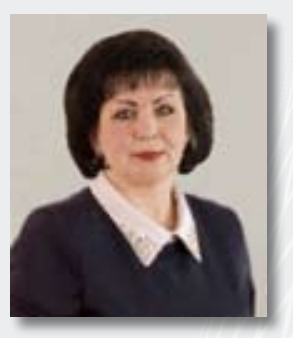

\section{КОРЧАГИНА}

Татьяна Викторовна

Заместитель директора ООО «Сибирский Институт

Горного Дела», канд. техн. наук, 653066, г. Кемерово, Россия, e-mail: t.korchagina@sds-ugol.ru

По сравнению с 2013 г. масса образования отходов IV класса опасности увеличилась на 5,8\%, а отходов I, II, III и $\mathrm{V}$ классов опасности уменьшилась на $11,1 \% ; 16,6 \% ; 10 \%$ и 0,8\% соответственно.

Из общего количества образовавшихся в 2014 г. отходов производства и потребления субъектами хозяйственной деятельности использовано 1064941,364 тыс. т (40,3\%) - и 347,982 тыс. т (0,01\%) обезврежено. По сравнению с 2013 г. объем использованных отходов увеличился на 175404,375 тыс. т (19,7\%), а обезвреженных на 57,025 тыс. т $(19,6 \%)[6,7]$.

Все отрасли промышленности неизбежно отрицательно влияют на состояние природной среды, однако угольная промышленность оказывает негативное влияние в особо крупных масштабах.

На предприятия по добыче полезных ископаемых приходится наибольший объем образования отходов, в 2014 г. он составил 2622947,834 тыс. т (99,3\%).

Количество образования, использования и размещения отходов на собственных объектах предприятий с учетом отнесения предприятий к видам экономической деятельности в 2009-2014 гг. представлено в табл. 1, 2 


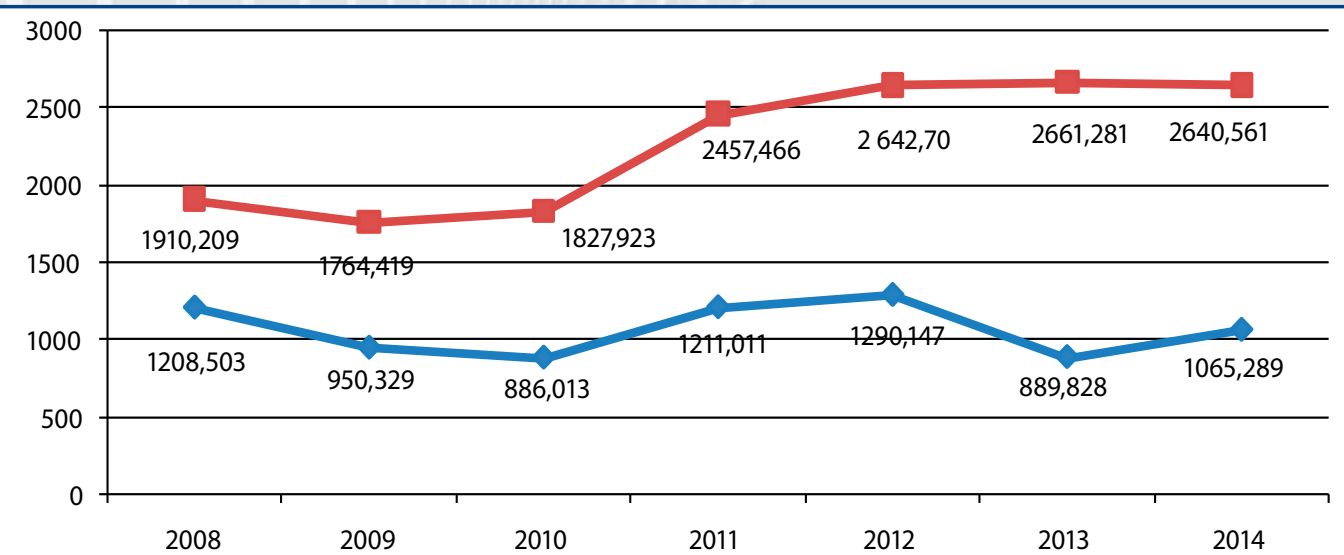

Рис. 1. Динамика образования, использования и обезвреживания отходов производства и потребления за 20082014 г2. на территории Кемеровской области

$\sim$ Объем использования и обезвреживания отходов, млн т - - Образовано отходов, млн т

Основную долю в структуре отходов угледобывающих предприятий составляет вскрышная порода, отнесенная к V классу опасности для окружающей среды. В 2014 г. объем отходов V класса опасности составил 2637,207 тыс. т, или $99,87 \%$ от общего объема отходов. Вскрышная порода используется на выполнение технического этапа рекультивации нарушенных горными работами земель, для отсыпки дамб, технологических дорог.

Предприятиями по добыче полезных ископаемых использовано и обезврежено в 2014 г. 1053813,97 тыс. т отхо- дов, что на 187130,749 тыс. т больше по сравнению с 2010 г. (866683,221 тыс. т), а также объем захоронения и хранения отходов в 2014 г. составил 1567438,586 тыс. т, что на 632848 , 496 тыс. т больше, чем в 2010 г. (934590,098 тыс. т) (рис. 2).

\section{Выводы}

Анализ данных по объему образования, использования и размещения отходов производства угледобывающими предприятиями, систематизированных авторами, свидетельствует о том, что угольная промышленность является

Динамика объемов образования, использования и размещения отходов на собственных объектах предприятий с учетом отнесения к видам экономической деятельности за 2009-2011 гг.

\begin{tabular}{|c|c|c|c|c|c|c|}
\hline \multirow{2}{*}{$\begin{array}{c}\text { Виды экономической } \\
\text { деятельности }\end{array}$} & \multirow{2}{*}{$\begin{array}{l}\text { Образование } \\
\text { отходов за } \\
2009 \text { г., тыс. т }\end{array}$} & \multicolumn{2}{|c|}{ Использовано отходов } & \multicolumn{2}{|c|}{$\begin{array}{l}\text { Размещено отходов на собс- } \\
\text { твенных объектах, тыс. т }\end{array}$} & \multirow{2}{*}{$\begin{array}{c}\text { Доля } \\
\text { образования } \\
\text { отходов, \% }\end{array}$} \\
\hline & & В организации, тыс. т & \% от образовавшихся & Хранение & Захоронение & \\
\hline Всего отходов & 1764418,707 & 950170,890 & 53,9 & 780412,281 & 131932,438 & 100 \\
\hline Сельское хозяйство & 246,416 & 202,810 & 82,3 & 2,263 & - & 0,014 \\
\hline Добыча полезных ископаемых & 1714388,379 & 921862,400 & 53,8 & 758187,447 & 130318,350 & 97,164 \\
\hline Обрабатывающие производства & 26416,972 & 7542,538 & 28,6 & 17157,791 & 681,520 & 1,5 \\
\hline $\begin{array}{l}\text { Производство и распределение } \\
\text { электроэнергии, газа и воды }\end{array}$ & 2710,088 & 56,670 & 2,1 & 2403,546 & 12,807 & 0,15 \\
\hline Строительство & 19617,023 & 19529,642 & 99,6 & 19,300 & 84,190 & 1,112 \\
\hline $\begin{array}{l}\text { Другие виды экономической } \\
\text { деятельности }\end{array}$ & 1039,829 & 976,830 & 93,9 & 2641,934 & 835,571 & 0,06 \\
\hline
\end{tabular}
деятельности

\section{Виды экономической
деятельности}

Образовани 2010 г., тыс. т

Всего отходов

Сельское хозяйство

Добыча полезных ископаемых

Обрабатывающие производства

Производство и распределение электроэнергии, газа и воды

Строительство

Другие виды экономической деятельности

\section{Виды экономической} еятельности

Всего отходов

Сельское хозяйство

Добыча полезных ископаемых

Обрабатывающие производства

Производство и распределение электроэнергии, газа и воды

Строительство

Другие виды экономической деятельности

\begin{tabular}{|c|c|c|c|c|c|}
\hline \multirow{2}{*}{$\begin{array}{c}\text { Образование } \\
\text { отходов за } \\
2010 \text { г., тыс. т }\end{array}$} & \multicolumn{2}{|c|}{ Использовано отходов } & \multicolumn{2}{|c|}{$\begin{array}{c}\text { Размещено отходов на собс- } \\
\text { твенных объектах, тыс. т }\end{array}$} & \multirow{2}{*}{$\begin{array}{c}\text { Доля об- } \\
\text { разования } \\
\text { отходов, \% }\end{array}$} \\
\hline & В организации, тыс. т & \% от образовавшихся & Хранение & Захоронение & \\
\hline 1827923,233 & 885854,587 & 49,2 & 954487,905 & 1042,442 & 100 \\
\hline 0,704 & 0,073 & 10,3 & - & - & 一 \\
\hline 1789924,994 & 866681,144 & 49,2 & 934110,450 & 479,649 & 97,92 \\
\hline 25519,935 & 8774,685 & 34,4 & 17425,463 & 3,015 & 1,39 \\
\hline 2863,951 & 6,12 & 0,2 & 2755,779 & - & 0,16 \\
\hline 8560,504 & 8560,118 & 99,9 & 1,454 & 40,510 & 0,47 \\
\hline 1053,145 & 1777,367 & 168,77 & 194,759 & 519,268 & 0,06 \\
\hline & & & & \multicolumn{2}{|c|}{ Продолжение табл. 1} \\
\hline $\begin{array}{l}\text { Образование } \\
\text { отходов за }\end{array}$ & \multicolumn{2}{|c|}{ Использовано отходов } & \multicolumn{2}{|c|}{$\begin{array}{c}\text { Размещено отходов на собс- } \\
\text { твенных объектах, тыс. т }\end{array}$} & \multirow{2}{*}{$\begin{array}{c}\text { Доля об- } \\
\text { разования } \\
\text { отходов, \% }\end{array}$} \\
\hline 2011 г., тыс. T & В организации, тыс. т & \% от образовавшихся & Хранение & Захоронение & \\
\hline 2457465,656 & 1210315,081 & 49,3 & 1246242,035 & 831,217 & 100 \\
\hline 254,821 & 111,815 & 43,9 & 20 & - & 0,01 \\
\hline 2422311,70 & 1189382,59 & 49,1 & 1230455,128 & 0,101 & 98,57 \\
\hline 20374,446 & 8614,707 & 42,3 & 12986,402 & 171,757 & 0,83 \\
\hline 3009,198 & 36,310 & 1,2 & 2577,56 & 1,895 & 0,12 \\
\hline 9758,861 & 9741,991 & 99,8 & - & - & 0,4 \\
\hline 1756,63 & 2427,689 & 138,20 & 220,945 & 657,464 & 0,07 \\
\hline
\end{tabular}

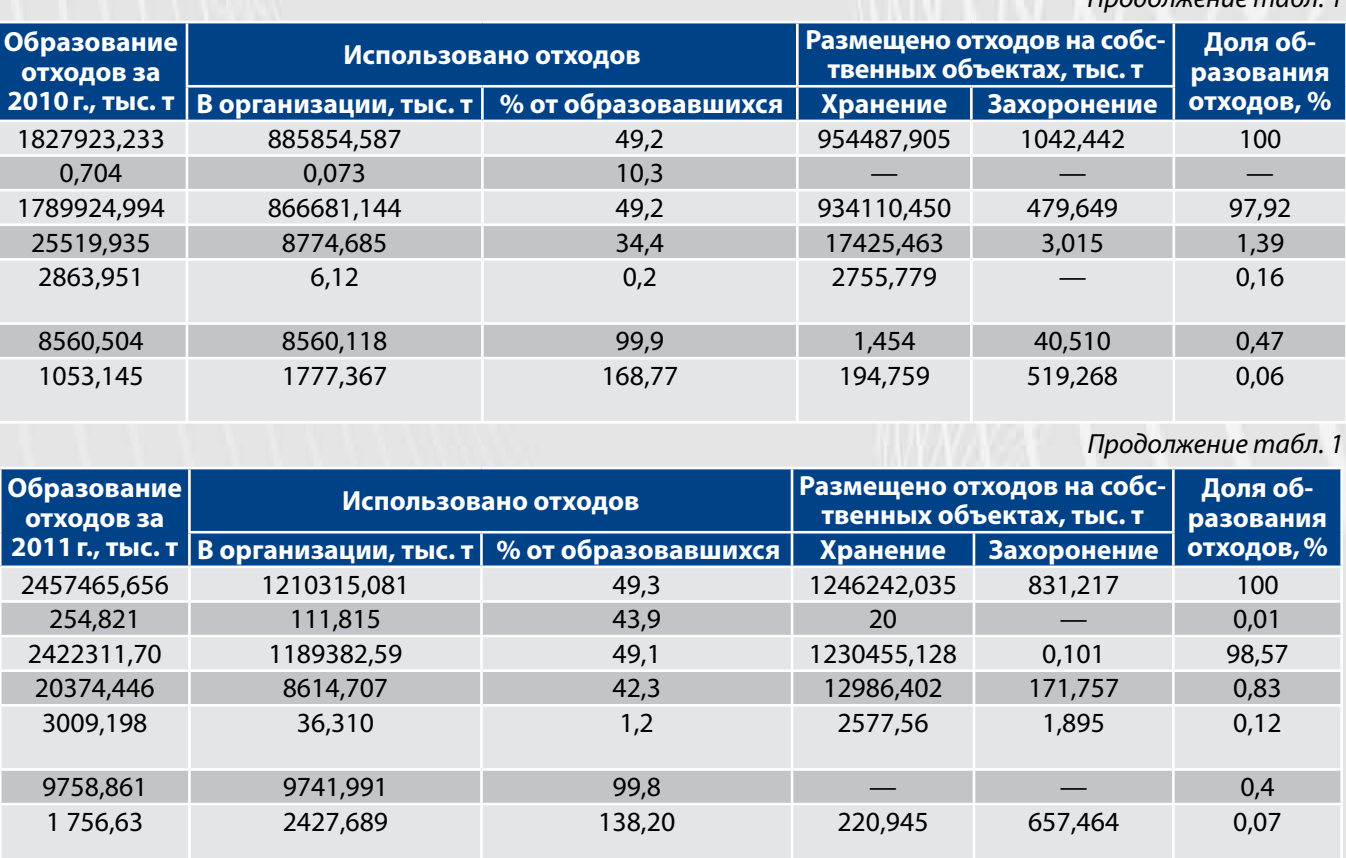

\begin{tabular}{|c|c|c|c|c|c|}
\hline 1827923,233 & 885854,587 & 49,2 & 954487,905 & 1042,442 & 100 \\
\hline 0,704 & 0,073 & 10,3 & - & - & - \\
\hline 1789924,994 & 866681,144 & 49,2 & 934110,450 & 479,649 & 97,92 \\
\hline 25519,935 & 8774,685 & 34,4 & 17425,463 & 3,015 & 1,39 \\
\hline 2863,951 & 6,12 & 0,2 & 2755,779 & - & 0,16 \\
\hline 8560,504 & 8560,118 & 99,9 & 1,454 & 40,510 & 0,47 \\
\hline 1053,145 & 1777,367 & 168,77 & 194,759 & 519,268 & 0,06 \\
\hline & & & & \multicolumn{2}{|c|}{ Продолжение табл. 1} \\
\hline $\begin{array}{c}\text { Образование } \\
\text { отходов за }\end{array}$ & \multicolumn{2}{|c|}{ Использовано отходов } & \multicolumn{2}{|c|}{$\begin{array}{c}\text { Размещено отходов на собс- } \\
\text { твенных объектах, тыс. т }\end{array}$} & \multirow{2}{*}{$\begin{array}{c}\text { Доля об- } \\
\text { разования } \\
\text { отходов, \% }\end{array}$} \\
\hline 2011 г., тыс. T & В организации, тыс. т & \% от образовавшихся & Хранение & Захоронение & \\
\hline 2457465,656 & 1210315,081 & 49,3 & 1246242,035 & 831,217 & 100 \\
\hline 254,821 & 111,815 & 43,9 & 20 & - & 0,01 \\
\hline 2422311,70 & 1189382,59 & 49,1 & 1230455,128 & 0,101 & 98,57 \\
\hline 20374,446 & 8614,707 & 42,3 & 12986,402 & 171,757 & 0,83 \\
\hline 3009,198 & 36,310 & 1,2 & 2577,56 & 1,895 & 0,12 \\
\hline 9758,861 & 9741,991 & 99,8 & - & - & 0,4 \\
\hline 1756,63 & 2427,689 & 138,20 & 220,945 & 657,464 & 0,07 \\
\hline
\end{tabular}


Таблица 2

Динамика объемов образования, использования и размещения отходов на собственных объектах предприятий с учетом отнесения к видам экономической деятельности за 2012-2014 гг.

\begin{tabular}{|c|c|c|c|c|c|c|}
\hline \multirow{2}{*}{$\begin{array}{c}\text { Виды экономической } \\
\text { деятельности }\end{array}$} & \multirow{2}{*}{$\begin{array}{c}\text { Образование } \\
\text { отходов за } \\
2012 \text { г., тыс. т }\end{array}$} & \multicolumn{2}{|c|}{ Использовано отходов } & \multicolumn{2}{|c|}{$\begin{array}{l}\text { Размещено отходов на собс- } \\
\text { твенных объектах, тыс. т }\end{array}$} & \multirow{2}{*}{$\begin{array}{c}\text { Доля о6- } \\
\text { разования } \\
\text { отходов, \% }\end{array}$} \\
\hline & & В организации, тыс. т & \% от образовавшихся & Хранение & Захоронение & \\
\hline Всего отходов & 2642698,721 & 1290037,426 & 48,8 & 1313313,559 & 13271,19 & 100 \\
\hline Сельское хозяйство & 377,930 & 196,052 & 51,9 & - & 0,004 & 0,01 \\
\hline Добыча полезных ископаемых & 2613000,841 & 1270831,512 & 48,6 & 1299307,157 & 12387,6 & 98,9 \\
\hline Обрабатывающие производства & 16986,522 & 7754,056 & 45,6 & 10584,192 & 84,466 & 0,65 \\
\hline $\begin{array}{l}\text { Производство и распределение } \\
\text { электроэнергии, газа и воды }\end{array}$ & 2425,055 & 37,075 & 1,5 & 2199,078 & - & 0,09 \\
\hline Строительство & 8468,468 & 8302,747 & 98,04 & 147,069 & - & 0,3 \\
\hline $\begin{array}{l}\text { Другие виды экономической } \\
\text { деятельности }\end{array}$ & 1439,905 & 2915,984 & 202,5 & 1076,063 & 799,12 & 0,05 \\
\hline
\end{tabular}

Продолжение табл. 2

\begin{tabular}{|c|c|c|c|c|c|c|}
\hline \multirow{2}{*}{$\begin{array}{c}\text { Виды экономической } \\
\text { деятельности }\end{array}$} & \multirow{2}{*}{$\begin{array}{l}\text { Образование } \\
\text { отходов за } \\
2013 \text { г., тыс. т }\end{array}$} & \multicolumn{2}{|c|}{ Использовано отходов } & \multicolumn{2}{|c|}{$\begin{array}{c}\text { Размещено отходов на собс- } \\
\text { твенных объектах, тыс. т }\end{array}$} & \multirow{2}{*}{$\begin{array}{l}\text { Доля о6- } \\
\text { разования } \\
\text { отходов, \% }\end{array}$} \\
\hline & & В организации, тыс. т & \% от образовавшихся & Хранение & Захоронение & \\
\hline Всего отходов & 2661281,133 & 889536,989 & 33,425 & 1693517,562 & 10919,388 & 100 \\
\hline Сельское хозяйство & 348,497 & 140,35 & 40,273 & 0 & 0 & 0,013 \\
\hline Добыча полезных ископаемых & 2644055,844 & 879624,211 & 33,268 & 1681897,799 & 8267,432 & 99,358 \\
\hline Обрабатывающие производства & 14222,762 & 6527,708 & 45,896 & 9723,089 & 287,63 & 0,534 \\
\hline $\begin{array}{l}\text { Производство и распределение } \\
\text { электроэнергии, газа и воды }\end{array}$ & 2229,325 & 55,756 & 2,501 & 1896,61 & 0 & 0,084 \\
\hline Строительство & 29,696 & 2,938 & 9,894 & 0 & 0 & 0,001 \\
\hline $\begin{array}{l}\text { Другие виды экономической } \\
\text { деятельности }\end{array}$ & 395,009 & 3186,026 & 806,57 & 0,064 & 2364,326 & 0,01 \\
\hline
\end{tabular}

Окончание табл. 2

\begin{tabular}{|c|c|c|c|c|c|c|}
\hline \multirow{2}{*}{$\begin{array}{c}\text { Виды экономической } \\
\text { деятельности }\end{array}$} & \multirow{2}{*}{$\begin{array}{c}\text { Образование } \\
\text { отходов за } \\
2014 \text { г., тыс. т }\end{array}$} & \multicolumn{2}{|c|}{ Использовано отходов } & \multicolumn{2}{|c|}{$\begin{array}{l}\text { Размещено отходов на собс- } \\
\text { твенных объектах, тыс. т }\end{array}$} & \multirow{2}{*}{$\begin{array}{c}\text { Доля о6- } \\
\text { разования } \\
\text { отходов, \% }\end{array}$} \\
\hline & & В организации, тыс. т & \% от образовавшихся & Хранение & Захоронение & \\
\hline Всего отходов & 2640560,661 & 1065289,35 & 40,34 & 1577259,817 & 2994,46 & 100 \\
\hline Сельское хозяйство & 464,967 & 379,4 & 81,6 & 0 & 0 & 0,02 \\
\hline Добыча полезных ископаемых & 2622947,834 & 1053813,97 & 40,18 & 1565380,321 & 2058,266 & 99,33 \\
\hline Обрабатывающие производства & 14351,195 & 6534,19 & 45,53 & 9940,733 & 32,824 & 0,54 \\
\hline $\begin{array}{l}\text { Производство и распределение } \\
\text { электроэнергии, газа и воды }\end{array}$ & 2283,251 & 96,45 & 4,22 & 1938,758 & 0 & 0,09 \\
\hline Строительство & 26,783 & 1,78 & 6,65 & 0,004 & 0 & 0,00 \\
\hline $\begin{array}{l}\text { Другие виды экономической } \\
\text { деятельности }\end{array}$ & 486,631 & 4463,56 & 23938,26 & 0,001 & 903,37 & 0,02 \\
\hline
\end{tabular}

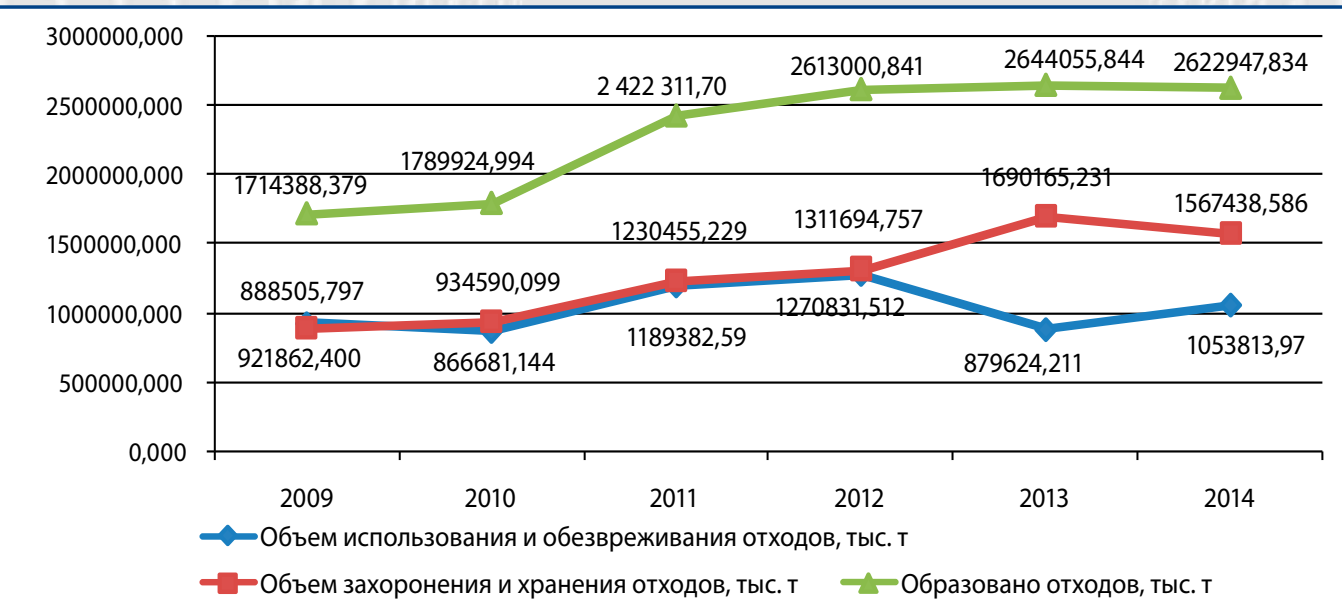

Рис. 2. Динамика объемов образования, использования и обезвреживания отходов производства и потребления за 20102014 г2. предприятиями по добыче полезных ископаемых на территории Кемеровской области

одной из основных отраслей, которая оказывает мощное техногенное воздействие на окружающую среду [8].

Специфичным для угледобычи характером воздействия на природную среду является использование земельных ресурсов, при котором происходит разрушение естественных природных ландшафтов - уничтожаются не только растительный, почвенный покров, почвообразующие слои литосферы, но и геологический фундамент ландшафта на сотни метров в глубину.

В целях совершенствования единой государственной политики в области обращения с отходами производс- тва и потребления на территории Кемеровской области разработано и действует Положение о порядке ведения регионального кадастра отходов Кемеровской области, которое определяет содержание и принципы формирования регионального кадастра отходов. А также создан банк данных инновационных технологий использования и обезвреживания отходов [9].

Однако, проблема утилизации и размещения отходов производства остается актуальной не только для Кузбасса, но и для других регионов страны, ведущих разработку полезного ископаемого. 


\section{Список литературы}

1. Ефимов В.И., Попов С. М., Харченко В. А. Экономическая оценка использования отходов гидродобычи угля. М.: Изд-во МГГУ, 2012. 141 с.

2. Качурин Н.М., Ефимов В.И., Мосина Е.К., Факторович В. В. Перспективы экологически безопасного использования отходов производства на территориях горнодобывающих регионов // Безопасность труда в промышленности. 2014. № 9. C. 81-84.

3. Ефимов В.И., Рыбак Л. В. Производство и окружающая среда. М.: МГГУ, 2012. 301 с.

4. Ефимов В.И., Попов С.М., Федяев П.М. К вопросу о формировании экономических инструментов оценки горнопромышленных отходов. Теория и практика экономического регулирования природопользования и охраны окружающей среды / Сборник трудов 13-й Международной научно-практической конференции Российского общества экологической экономики. RSEE-2015 / РОЭЭ-2015. Казань, 7-11 июля 2015. С. 136-143.
5. Корчагина Т.В., Рыбак В.Л., Рыбак Л.Л. Образование отходов производства и потребления на территории Кемеровской области // Известия Тульского государственного университета. Науки о Земле. 2013. Вып. 1. С. 15-19.

6. О состоянии и охране окружающей среды Кемеровской области в 2014 г.: доклад Департамента природных ресурсов и экологии Кемеровской области. Кемерово: Администрация Кемеровской области, 2015.

7. О состоянии и охране окружающей среды Кемеровской области в 2013 году: доклад Департамента природных ресурсов и экологии Кемеровской области. Кемерово: Администрация Кемеровской области, 2014.

8. Поляков В.В., Ефимов В.И., Корчагина Т. В. Эколого-экономический анализ воздействия предприятий угольной отрасли на окружающую среду: монография. М.: Изд-во МГГУ, 2006. 172 с.

9. Положение о порядке ведения регионального кадастра отходов Кемеровской области (утв. постановлением Коллегии Администрации Кемеровской области от 30.12.2011 № 640) (в ред. От 17.07.2014 № 281).

UDC 622.85:622.872:502.3:661.92(571.17) @ V.I. Efimov, R.V. Sidorov, T.V. Korchagina, G.A., 2015

ISSN 0041-5790 (Print) • ISSN 2412-8333 (Online) • Ugol' - Russian Coal Journal, 2015, № 12, pp. 73-76

Title

GENERATION OF COAL MINING PRODUCTION WASTES IN THE KEMEROVO REGION TERRITORY

DOI: http://dx.doi.org/10.18796/0041-5790-2015-12-73-76

\section{Authors}

Efimov V.I. ${ }^{1}$, Sidorov R.V. ${ }^{2}$, Korchagina T.V. ${ }^{2}$

${ }^{1}$ National University of Science and Technology "MISiS" (NUST "MISiS"), Moscow, 119049, Russian Federation

${ }^{2}$ The Mining Engineering Institute of Siberia LLC, Kemerovo, 653066, Russian Federation

\section{Authors' Information}

Efimov V.I., Doctor of Engineering Sciences, Professor of the Mining Institute, e-mail: v.efimov@sds-ugol.ru

Sidorov R.V., Director, e-mail: r.sidorov@sds-ugol.ru

Korchagina T.V., PhD (Engineering), Deputy Director,

e-mail: t.korchagina@sds-ugol.ru

\section{Abstract}

The issues of wastes disposal at enterprises for useful minerals extraction in the Kemerovo Region territory and their negative environmental impact are reviewed. The analysis of data on wastes volume generation, utilization and disposal gives evidence that the coal mining industry is the one of the principal industries that produces the powerful technogenic impact on the environment. The specific feature of environmental impact for the coal mining is the land resources use with destruction of natural landscapes - not only the vegetative soil cover and soil-forming layers of lithosphere but the geologic foundation of landscape to the hundreds of meter deep are destroyed. This results in the productive lands withdrawal from the economic turnover because of industrial wastes accumulation For the purpose of improving the unified State policy in the field of industrial and consumer wastes disposal in the Kemerovo Region territory the Regulation for procedure of regional waste cadastre maintenance was developed and remains in force. The problem of industrial and consumer wastes utilization and disposal is urgent not only for Kuzbass but for other regions where the useful minerals are mined.

\section{Keywords}

Production, coal mining facility, wastes generation, waste hazard class

\section{References}

1. Efimov V.I., Popov S.M. \& Harchenko V.A. Ekonomicheskaya otsenka ispol'zovaniya otkhodov gidrodobychi uglya [Economic assessment of use of waste of hydrocoal mining]. Moscow, MSMU Publ., 2012, 141 p.

2. Kachurin N.M., Efimov V.I., Mosina E.K., Faktorovich V.V. Perspektivy ekologicheski bezopasnogo ispol'zovaniya otkhodov proizvodstva na territoriyakh gornodobyvayushchikh regionov [Prospects of ecologically safe use of production wastes in territories of mining regions]. Bezopasnost' truda $\mathrm{v}$ promyshlennosti - Safety of work in the industry, 2014, no. 9, pp. 81-84.
3. Efimov V.I. \& Rybak L.V. Proizvodstvo i okruzhayushchaya sreda [Production and environment]. Moscow, MSMU Publ., 2012, 301 p.

4. Efimov V.I., Popov S.M. \& Fedyaev P.M. K voprosu o formirovanii ekonomicheskikh instrumentov otsenki gornopromyshlennykh otkhodov. Teoriya i praktika ekonomicheskogo regulirovaniya prirodopol'zovaniya i okhrany okruzhayushchey sredy [To a question of formation of economic tools of an assessment of mining waste. Theory and practice of economic regulation of environmental management and environmental protection]. Sbornik trudov 13-y Mezhdunarodnoy nauchno-prakticheskoy konferentsii Rossiyskogo obshchestva ekologicheskoy ekonomiki.

[Collection of works of the 13th International scientific and practical conference of the Russian society of ecological economy]. RSEE-2015, Kazan, 7-11 July 2015, pp. 136-143.

5. Korchagina T.V., Rybak V.L. \& Rybak L.L. Obrazovanie otkhodov proizvodstva I potrebleniya na territorii Kemerovskoy oblasti [The industrial and consumer wastes generation in the Kemerovo Region territory]. Izvestiya Tul'skogo gosudarstvennogo universiteta. Nauki o Zemle. - Proceedings of Tula State University. Earth Sciences, 2013, Issue 1, pp. 15-19.

6. Osostoyanii lokhrane okruzhayuschey sredy Kemerovskoy oblastiv 2014 godu: doklad Departamenta prirodnykh resursov l ekologii Kemerovskoy oblasti [On the state and protection of Kemerovo Region environment in 2014: Report of Natural Resources and Ecology Department of Kemerovo Region], Kemerovo, Administration of Kemerovo Region, 2015.

7. O sostoyanii lokhrane okruzhayuschey sredy Kemerovskoy oblastiv 2013 godu: doklad Departamenta prirodnykh resursov l ekologii Kemerovskoy oblasti [On the state and protection of Kemerovo Region environment in 2013: Report of Natural Resources and Ecology Department of Kemerovo Region]. Kemerovo, Administration of Kemerovo Region, 2014.

8. Polyakov V.V., Efimov V.I. \& Korchagina T.V. Ekologo-ekonomicheskiy analiz vozdeystviya predpriyatiy ugol'noy otrasli na okruzhayushchuyu sredu. Monografiya [Ekologo-ekonomichesky analysis of impact of the enterprises of coal branch on environment. Monograph]. Moscow, MSMU Publ., 2006, 172 p. 9. Polozhenie o poryadke vedeniya regionalnogo kadastra otkhodov Kemerovskoy oblasti [Regulations for Kemerovo region waste cadastre maintenance procedure]. Utv. postanovleniem Kollegii Administratsii Kemerovskoy oblasti [Approved by Order of Kemerovo Region Administration Board], no. 640 of 30.12.2011 (as amended by Order no. 281 of 17.07.2014). 

горнорудной промышленности

С 6 по 8 октября 2015 г. в Москве в гостинице «Рэдиссон Славянская» прошел 11-й Горнопромышленный форум МАЙНЕКС Россия 2015. Форум проводился при поддержке федерального агентства по недропользованию Российской Федерации и 19 российских и международных компаний

Форум МАЙНЕКС Россия проводится в Москве с 2005 г. и является одним из самых крупных и представительных международных мероприятий, посвященных актуальным проблемам развития геологоразведки, добычи и переработки твердых полезных ископаемых в России и странах Евразийского экономического сообщества

В этом году, организованный под девизом «Опережающее развитие - перспективы и возможности» форум МАЙНЕКС Россия 2015 собрал свыше 500 руководителей, экспертов и инвесторов из России и 17 стран мира. Впервые в работе форума приняли участие делегации из Китайской ассоциации золота, Всемирного Совета по золоту, министерства энергетики и горной промышленности Республики Куба и компаний — производителей калия из России и Беларуси.

Традиционная встреча профессиональных участников российской горнорудной отрасли проходила в условиях переосмысления векторов развития российской экономики на фоне неопределенности на глобальных рынках, ставшей новой нормой для недропользователей и инвесторов.

Российская экономика глубоко интегрирована в мировую систему производства. В нынешней ситуации неопределенности для России, помимо решения относительно краткосрочных задач «обыгрывания» предкризисных экономических позиций, главным вопросом является формирование принципиально новой модели экономического роста, нацеленной на опережающее развитие и реализацию внутреннего потенциала страны.

В рамках форума МАЙНЕКС Россия 2015 было представлено свыше 100 докладов и презентаций, состоялась открытая дискуссия с участием руководителей российских и международных горнодобывающих компаний; ведущих специалистов-практиков и ученых; руководителей отраслевых министерств и регионов, вошедших в федеральную программу опережающего развития; представителей законодательных органов власти; отечественных и зарубежных инвесторов.

В рамках дискуссий обсуждались:

- Перспективные направления развития горной отрасли в контексте происходящих в России глубоких экономических преобразований.

- Потенциальные возможности и механизмы для стимулирования развития в горной отрасли.

- Новые подходы, стратегии и решения для адаптации предприятий горной отрасли к изменившимся условиям и обеспечения выхода на новый уровень конкурентоспособности и опережающего развития.

На площадке форума было проведено три мастер-класса, двенадцать сессий и три ассоциированных мероприятия, организованных при участии Федерального агентства по недропользованию РФ, экономической секции Общества экспертов России по недропользованию (ОЭРН), компаний IMC Montan и Micromine.

На отраслевой выставке, организованной в ходе форума, были представлены стенды 45 компаний и организаций. Вы- ставку посетили свыше 700 специалистов из российских и международных компаний.

В партнерстве со старт-ап-компанией Me. You. ru оргкомитет форума предоставил участникам форума новые интерактивные возможности для установления знакомств, проведения опросов, просмотра презентаций и фотографий. Новыми услугами воспользовались 96 участников. По хештегу \#Minexforum было подтянуто 554 фотографии (всего 595 твитов). Сервис синхронно проектору показал 75 презентаций в телефонах гостей. Они будут доступны всем участникам через сервис в течение двух лет.

В рамках форума были успешно проведены: девятый международный конкурс «Российская горная награда» и четвертый конкурс любительской фотографии «Россия горная».

Конкурс отраслевых компаний и руководителей «Российская горная награда» ежегодно проводится в рамках форума «МАЙНЕКС Россия» С 2007 г. Цель его проведения - создание независимой и объективной платформы для предоставления выдающихсядостижений российских и международных компаний в области развития и улучшения стандартов и практики.

12-й Горнопромышленный форум МАЙНЕКС Россия состоится 4-6 октября 2016 г. в г. Москве. Если вы планируете принять участие форуме, пожалуйста, пришлите краткое сообщение на адрес admin@minexforum. com. Организаторы вышлют приглашение для регистрации и условия участия.

До следующего года форум МАЙНЕКС Россия 2015 «переезжает» на портал http://minex. club, где можно создать авторский блог, опубликовать новые материалы и пригласить к общению других экспертов. По мере пополнения портал будет развиваться и дополняться новым функционалом.
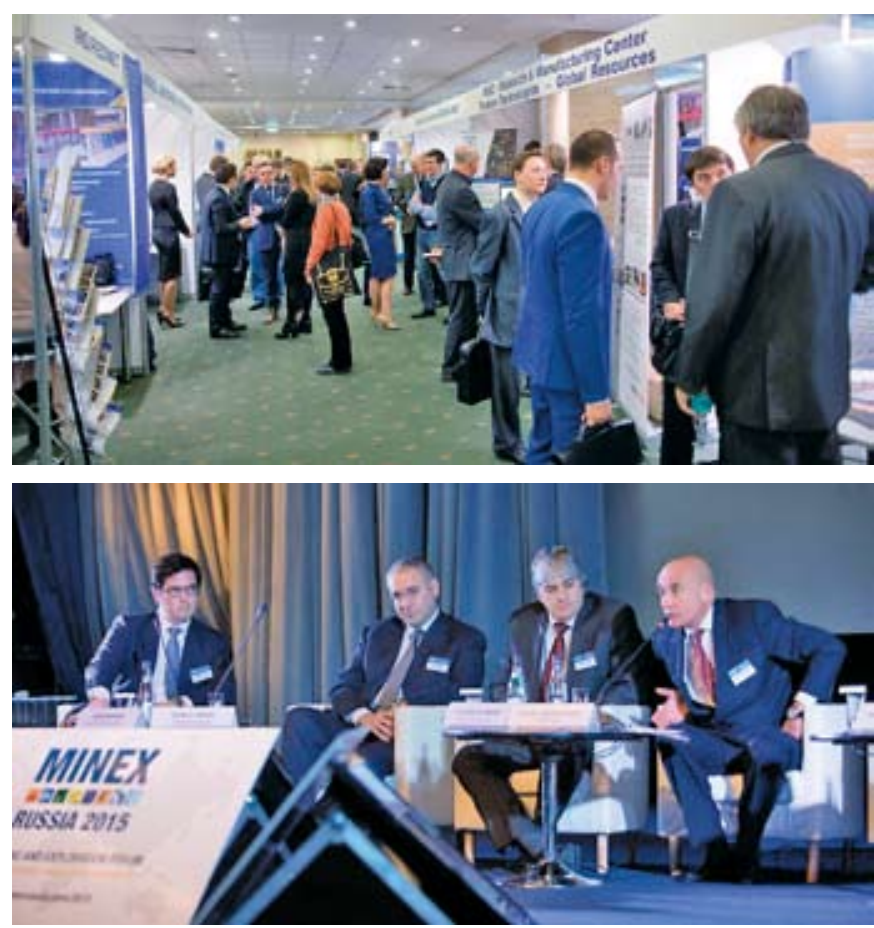


\section{VI Международная конференция «Железнодорожные перевозки горно-металлургических грузов РФ»}

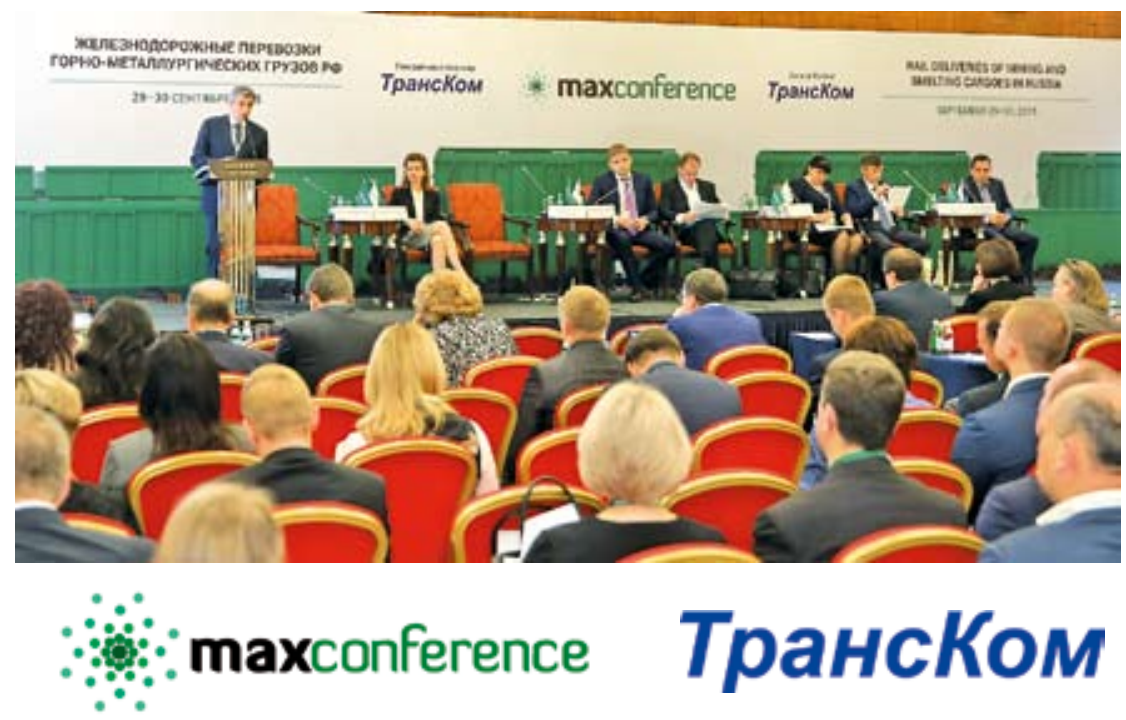

Компания MAXConference провела VI Международную конференцию «Железнодорожные перевозки горно-металлургических грузов РФ" в Москве, 29-30 сентября 2015 г. Генеральным партнером конференции выступила компания «ТрансКом». Мероприятие проводилось при партнерской поддержке «Лестэр Информационные Технологии", "Stena Line», "Rail Commerce», "Nurminen Logistics» u npu yчacmuu "Port of Kokkola», «РЖД Логистика» и «Rauanheimo».

В течение шести лет интерес к конференции не ослабевает, география участников с каждым разом расширяется. В этом году более 150 делегатов из России, Казахстана, Украины, Белоруссии, Финляндии, Норвегии, Латвии, Германии и Польши приняли участие в мероприятии. На одной площадке делились опытом и озвучивали свои предпочтения топ-менеджеры операторских компаний, руководители транспортных управлений крупнейших горно-металлургических предприятий России и стран ближнего зарубежья, представители РЖД, ФАС России, а также вагоностроительных, вагоноремонтных компаний и морских терминалов.

Резюмируя доклады конференции, можно выделить четыре тренда, которые определяют развитие отрасли железнодорожных перевозок горно-металлургических грузов. Первый тренд — клиентоориентированность; второй - эффективность резервных мощностей (IT-решения, повышение эффективности работы персонала, реформирование железнодорожного транспорта, усовершенствование внутризаводской транспортной инфраструктуры); третий - выстраивание партнерских отношений между всеми участниками рынка; четвертый - ставка на долгосрочное планирование.

Мероприятие прошло в формате открытого диалога между представителями ФАС, компаниями-грузовладельцами, операторами и РЖД. Выступление представителей ФАС вызвало большой интерес, в особенности много вопросов касалось разработки методов индексации тарифов и перспектив применения двухступенчатого индексирования. По мнению ФАС, двухступенчатое индексирование направлено в первую очередь на то, чтобы РЖД повысили эффективность, а грузоотправители могли планировать свои отгрузки и понимали, какой будет тариф на железнодорожные перевозки. Анатолий Кужель, заместитель начальника Центральной дирекции управления движением - начальник управления движением РЖД, на просьбу зала прокомментировать ситуацию с тарифами сказал, что «просто взять и изменить тарифную систему - не в компетенции ОАО «РЖД». Сделать это может только го- сударство, а предложения РЖД являются комплексными и направлены на привлечение грузов, однако не всегда учитываются регуляторами. А. Кужель отметил, что в РЖД установлен максимальный и минимальный пределы тарифного коридора, которые применимы в основном для тех грузоотправителей, которые дают гарантированный и стабильный объем перевозок.

Эксперты представили прогноз развития рынка железнодорожных перевозок, отметив, что рынок становится биржевым. Как считают эксперты, изменение рынка требует от компаний-операторов дополнительных компетенций.

Большое внимание было уделено вопросам преодоления инфраструктурных ограничений для перевозки угля. Выступающие считают, что для решения этой проблемы необходимо бюджетное финансирование, особенно для развития портовых мощностей, технологий сокращения времени оборотов вагонов, «расшивки узких мест» и для использования инновационных вагонов.

Спикеры сессии, посвященной экспортным перевозкам горно-металлургической продукции, рассказали о том, как в условиях санкций и сложившейся экономической ситуации оптимизировать транспортировку грузов через территорию Украины, Белоруссии и Финляндии, используя новые транспортные технологии.

Компания MAXConference выражает большую благодарность докладчикам, модераторам и участникам из компаний: ФГК, Thomson Reuters, ТрансКом, ИПЕМ, ОМКСталь, ФАС России, РЖД, Brunswick Rail, ЕВРАЗ НТМК, НЛМК, Промнерудтранс, Мечел-Транс, Трансгарант, Северсталь, РЖД Логистика, ПМХ-Транспорт, Морстройтехнология, ИЭРТ, Лестэр ИТ, Rail Commerce, ТЭК ММК, Укрзализныця, ЛЕМТРАНС ТРАНЗИТ, БелорУсская железная дорога, VR-Group, Серовский завод ферросnлавов, Инфотек-Балтика М, MMI-PRO, Кузбассразрезуголь, Stena Line, ИЭРТ, Восток 1520, Кузбасская топливная компания, Объединение вагоностроителей, ВРК2, Уралвагонзавод, Алтайвагон, ТФМ-Логистик. 


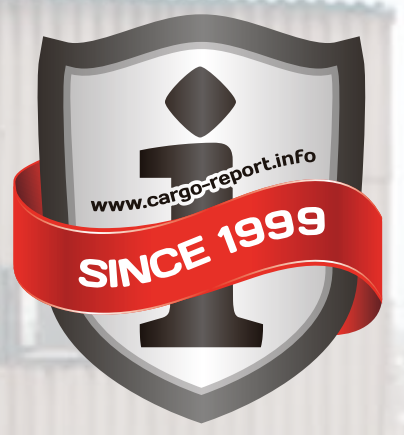

\section{Анализ железнодорожных перевозок}

\section{группы Уголь каменный \\ за ноябрь 2014 г. - октябрь 2015 г., тыс. т \\ ВНУТРИРОССИЙСКИЕ ПЕРЕВОЗКИ}

Динамика объемов

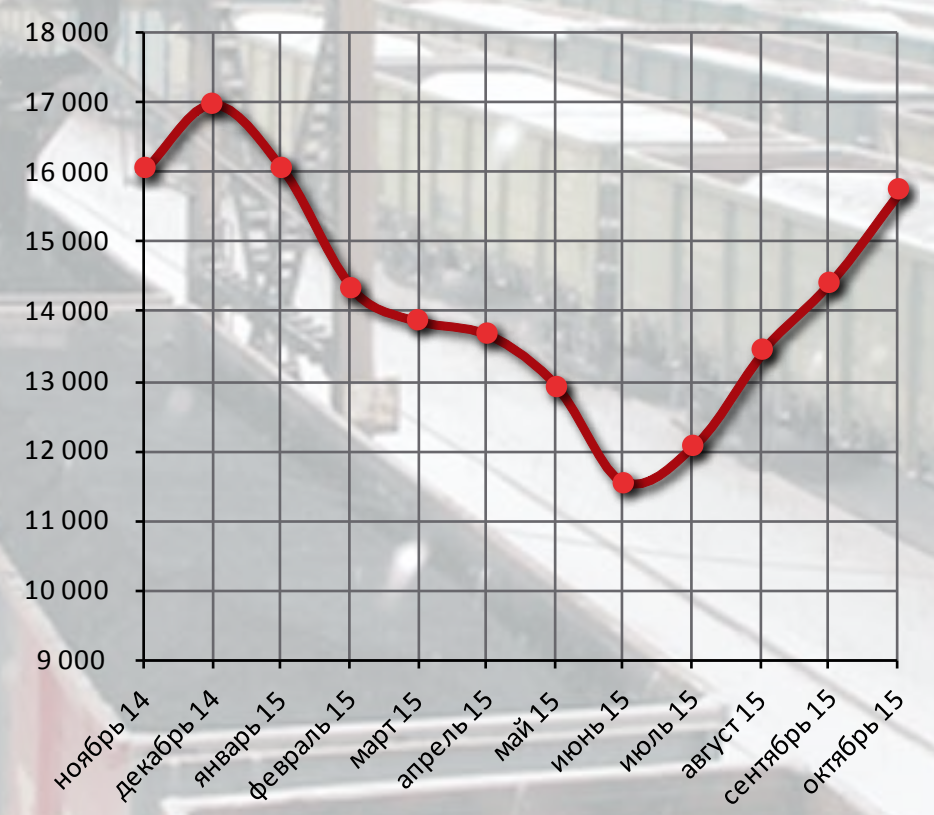

Регионы отправления
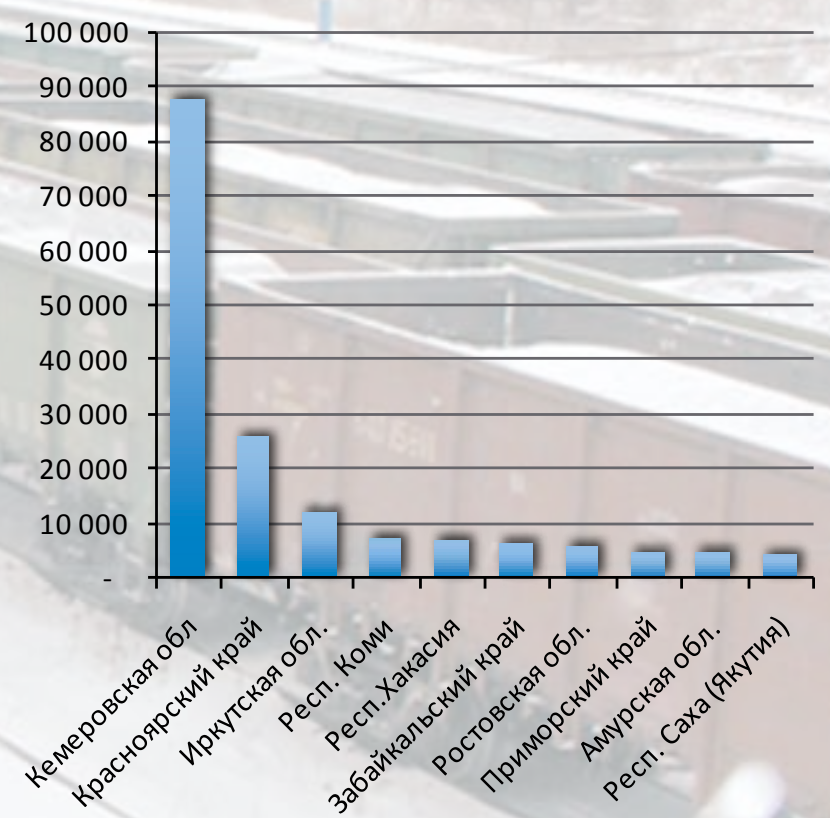

\section{ЭКСПОРТНЫЕ ПЕРЕВОЗКИ}

Динамика объемов

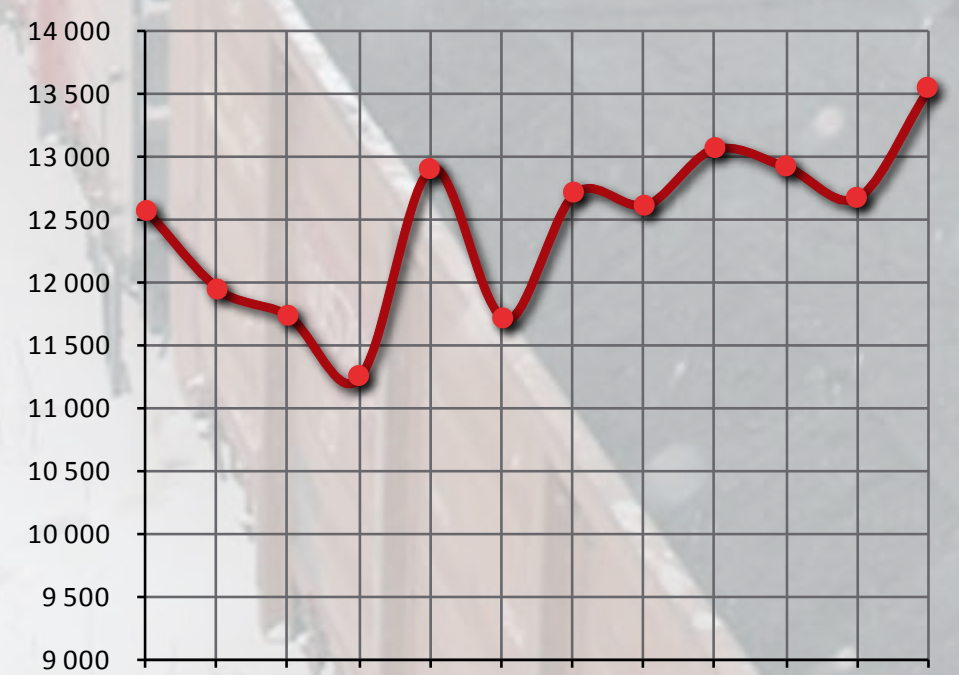

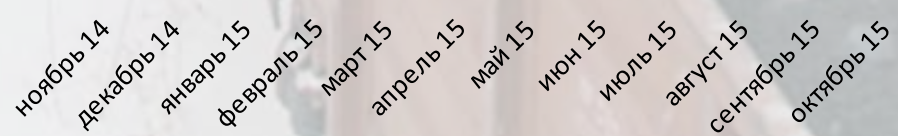

Государства назначения
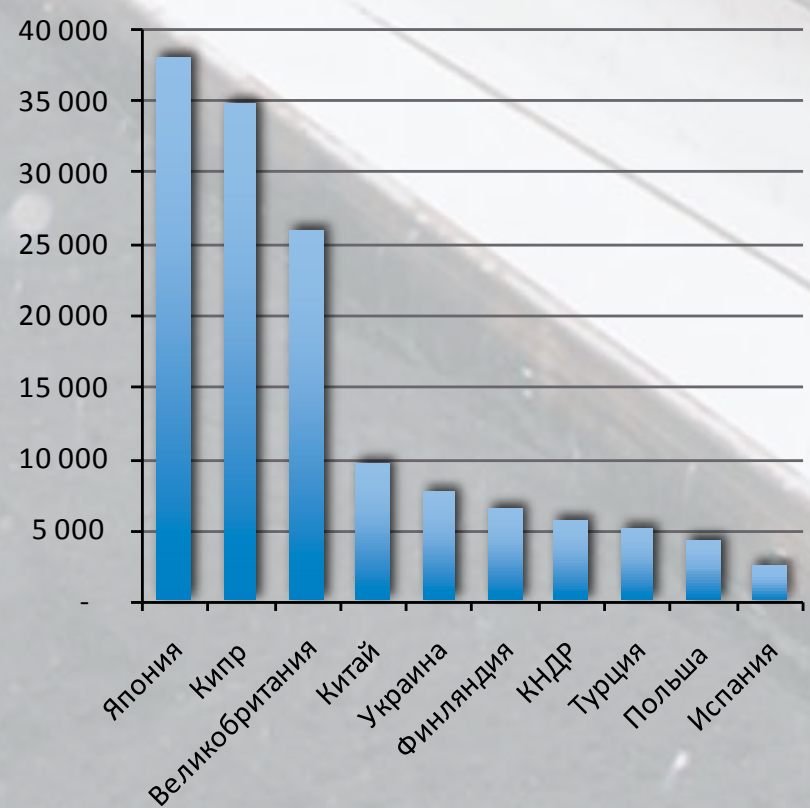

\section{www.cargo-report.info}

информационно-справочный портал - железнодорожные перевозки статистика • справочники • каталоги • консультации 


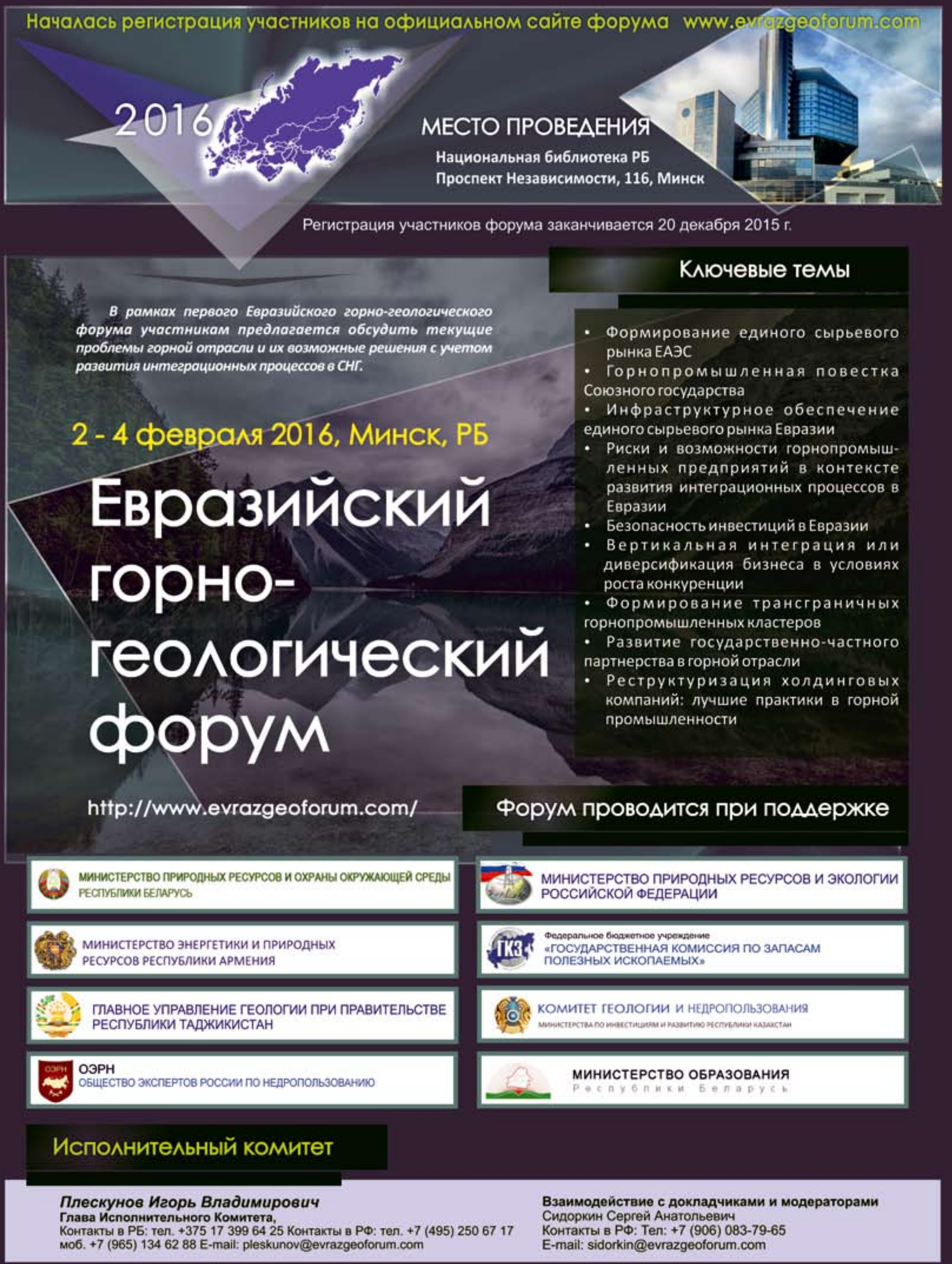




\section{Перечень статей,}

\section{опубликованных в журнале «Уголь» в 2015 году}

\begin{tabular}{|c|c|c|}
\hline & \\
\hline & № & C \\
\hline \multicolumn{3}{|l|}{ ПЕРСПЕКТИВЫ. РЕГИОНЫ. РЫНОК УГЛЯ } \\
\hline $\begin{array}{l}\text { Артемьев В.Б. Наши успехи, достижения и рекорды В } \\
\text { юбилейный год 70-летия Великой Победы }\end{array}$ & 8 & 7 \\
\hline АО «Разрез Березовский» Уникальный юбиляр & 8 & 23 \\
\hline $\begin{array}{l}\text { Байсаров Р. С. Концептуальные подходы к стратегии } \\
\text { освоения Элегестского месторождения Улуг-Хемского } \\
\text { угольного бассейна Республики Тыва }\end{array}$ & 12 & 44 \\
\hline $\begin{array}{l}\text { Борщевич А. М. Холдинг «ТопПром»: «юбилейный» } \\
\text { День шахтера }\end{array}$ & 8 & 56 \\
\hline Бурцев С. В. АО ХК «СДС-Уголь»: уверенное развитие & 8 & 36 \\
\hline $\begin{array}{l}\text { Бурцев С. В., Стихуров В.Е., Субботин С. А. Эффек- } \\
\text { тивное использование системы PreVail’ на предпри- } \\
\text { ятиях компании «СДС-Уголь» }\end{array}$ & 8 & 51 \\
\hline $\begin{array}{l}\text { Гаммершмидт А.А. Состояние и перспективы разви- } \\
\text { тия угольной промышленности Кузбасса }\end{array}$ & 5 & 14 \\
\hline $\begin{array}{l}\text { Глинина О.И. Национальный горнопромышленный } \\
\text { форум }\end{array}$ & 1 & 4 \\
\hline Глинина О.И. Неделя горняка - 2015 & 3 & 8 \\
\hline $\begin{array}{l}\text { Глинина О.И. Неделя Металлов и Горной промыш- } \\
\text { ленности России и СНГ } 2015\end{array}$ & 7 & 30 \\
\hline $\begin{array}{l}\text { Глинина О.И. Рынок угля России: готовность } \\
\text { к биржевой торговле }\end{array}$ & 11 & 66 \\
\hline \begin{tabular}{|l} 
Горбанева Светлана «Южная угольная компания» \\
выходит на новые рубежи развития
\end{tabular} & 8 & 62 \\
\hline \begin{tabular}{|l|} 
Гринвальд К. Ю. Главные слагаемые успеха \\
«Прокопьевского угольного разреза»
\end{tabular} & 8 & 46 \\
\hline $\begin{array}{l}\text { Гушинец В.А. ОАО ХК «СДС-Уголь»: основная } \\
\text { задача - рост добычи угля }\end{array}$ & 3 & 17 \\
\hline Килин А.Б. Рекорды нужны не для гордости & 8 & 26 \\
\hline $\begin{array}{l}\text { Королева А. АО «СУЭК-Красноярск»: рекорды и } \\
\text { инновации }\end{array}$ & 8 & 14 \\
\hline $\begin{array}{l}\text { Курбанов Н.Х., Рафиенко В.А. Развитие угледобыва- } \\
\text { ющих предприятий Дальнего Востока (за период } \\
\text { с } 1965 \text { по } 2015 \text { гг.) }\end{array}$ & 12 & 40 \\
\hline Михалева М. Движение только вперед! & 8 & 30 \\
\hline $\begin{array}{l}\text { НП Горнопромышленники России Итоги Первого } \\
\text { Национального горнопромышленного форума }\end{array}$ & 3 & 4 \\
\hline ОАО «СУЭК-Кузбасс» На крепких позициях & 8 & 12 \\
\hline $\begin{array}{l}\text { ОАО «Приморскуголь» Успехи приморских шахте- } \\
\text { ров }\end{array}$ & 8 & 32 \\
\hline $\begin{array}{l}\text { ОАО «Угольная компания «Северный Кузбасс» } \\
\text { Наши приоритеты: безопасность и здоровье сотруд- } \\
\text { ников, стабильная работа и долгосрочное сотрудни- } \\
\text { чество }\end{array}$ & 8 & 67 \\
\hline $\begin{array}{l}000 \text { «Восточная горнорудная компания» Перспек- } \\
\text { тивы сахалинского угля. Кризис? Забудьте! }\end{array}$ & 3 & 26 \\
\hline \begin{tabular}{|l|} 
Плакиткина Л.С. Анализ развития угольной про- \\
мышленности в Республике Казахстан в период с 2000 \\
по 2014 г. и тенденции перспективного развития \\
\end{tabular} & 4 & 80 \\
\hline $\begin{array}{l}\text { Плакиткина Л.С. Развитие угольной промышлен- } \\
\text { ности в республиках Средней Азии в постсоветский } \\
\text { период и тенденции их перспективного развития }\end{array}$ & 6 & 68 \\
\hline \begin{tabular}{|l|} 
Пресс-служба Минэнерго России В Минэнерго \\
России состоялось заседание Межведомственного \\
координационного Совета по вопросам энергосбере- \\
жения и повышения энергоэффективности
\end{tabular} & 6 & 4 \\
\hline Реутов И.А. АО «Черниговец»: движение вперед & 8 & 40 \\
\hline
\end{tabular}

\begin{tabular}{|l|c|c|}
\hline Рудаков О.Ю. Построенный с нуля & 11 & 4 \\
\hline $\begin{array}{l}\text { Рыжков К.М. Разрез «Киселёвский»: становление и } \\
\text { перспективы }\end{array}$ & 8 & 48 \\
\hline Создание морской горнодобывающей отрасли России & 10 & 80 \\
\hline Степанов С.С. Вместе мы станем сильнее & 3 & 22 \\
\hline $\begin{array}{l}\text { Ужахов Б.А. Стратегия функционирования ОАО } \\
\text { «Русский Уголь» в условиях нестабильности угольных } \\
\text { рынков }\end{array}$ & 8 & 60 \\
\hline Федоров И.Г. Разрез «Восточный» - первый юбилей! & 8 & 44 \\
\hline Јоу Global: надежный партнер, который всегда рядом & 10 & 20 \\
\hline $\begin{array}{l}\text { ThyssenKrupp Industrial Solutions отметил 20-летие } \\
\text { в России симпозиумом для заказчиков }\end{array}$ & 11 & 10 \\
\hline
\end{tabular}

\section{ПОДЗЕМНЫЕ РАБОТЫ}

Баскаков В.П., Розенбаум М. А., Калинин С. И., Семенцов В. В., Добровольский М.С. Отработка мощных угольных пластов, опасных по газодинамическим явлениям, системой коротких забоев \begin{tabular}{|l|c|c|}
\hline Блак Tомас (Blak Thomas) Автоматизация EICKHOFF & 10 & 22 \\
\hline
\end{tabular} гарантирует безопасность и качество - в России ввели в эксплуатацию первую лаву, работающая в автоматическом режиме

Буялич Г.Д., Тарасов В.М., Тарасова Н.И. Эффективность работы лавы в процессе работы новой технологии монтажа и эксплуатации секций механи зированной крепи, где челноковый метод резания угля - не возможность комплекса, а технологическая необходимость

Вартанов А. 3., Петров И. В., Федаш А. В. Научнометадические основы принятия проектных решений по комбинированной отработке пластов длинными и короткими забоями на угледобывающих предприятиях

Кариман С. А. О создании шахты С высокими техникоэкономическими показателями

Климов В. В., Ремезов А. В., Зайнулин Р. Р. Исследование влияния опорного давления очистного забоя 18-8 на конвейерный штрек 18-6, и его крепление на пласте «Толмачевский» в границах шахтного поля шахты «Полысаевская»

\begin{tabular}{|l|l|l|}
\hline Клишин В. И., Опрук Г. Ю., Сентюрев А. В., Николаев & 11 & 12
\end{tabular} А. В. Опыт применения направленного гидроразрыва основной кровли при выводе механизированного комплекса из монтажной камеры

Леконцев Ю. М., Сажин П. В., Хорешок А. А., Салихов А.Ф., Исамбетов В.Ф. Новое решение подготовки монтажной камеры для тонких пластов

Разумов Е. А., Айкин А. В., Гречишкин П. В., Петров В. И., Позолотин А.С. Программное обеспечение РПАК для автоматизации расчета параметров анкерной крепи

Разумов Е. А., Гречишкин П. В., Опрук Г. Ю., Дудин А. А., Венгер В.Г. Опыт поддержания горных выработок при влиянии подработки в условиях шахты «Распадская»

Ремезов А. В., Рябков Н. В., Новоселов С. В., Кочкин P.О. Комплексный подход при формировании паспорта выемочных участков, проведения и крепления подземных выработок

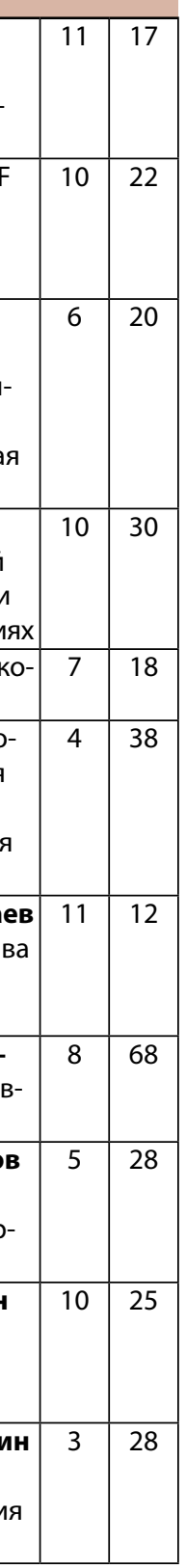




\begin{tabular}{|c|c|c|}
\hline & № & $\mathrm{C}$ \\
\hline $\begin{array}{l}\text { Сластунов С. В., Каркашадзе Г. Г., Ермак Г. П., Ютяев } \\
\text { Е. П. Предварительный и оперативный прогноз до- } \\
\text { пустимых нагрузок на очистной забой при интенсив- } \\
\text { ной отработке газоносных угольных пластов }\end{array}$ & 3 & 30 \\
\hline $\begin{array}{l}\text { Харитонов И.Л., Ремезов А. В., Новоселов С. В., } \\
\text { Кочкин Р. О. Проверка адекватности математической } \\
\text { модели проявления опорного давления в очистных } \\
\text { забоях №1382 и №1384, ее характеристика и реко- } \\
\text { мендации к практическому применению для пласта } \\
\text { «айкаимский» шахты им. } 7 \text { Ноября ОАО «СУЭК-Куз- } \\
\text { басс» в сложных зонах }\end{array}$ & 2 & 22 \\
\hline $\begin{array}{l}\text { Харитонов И.Л., Ремезов А. В., Новоселов С. В., } \\
\text { Кочкин Р. О. Разработка модели проявления опорно- } \\
\text { го давления в массиве горных пород лавы № } 1382 \text { по } \\
\text { пласту «Байкаимский», в зоне взаимовлияния очист- } \\
\text { ного забоя и конвейерного и путевого уклонов № } 31\end{array}$ & 1 & 20 \\
\hline $\begin{array}{l}\text { Яковлев Д. В., Баскаков В. П., Розенбаум М. А., } \\
\text { Калинин С. И. К вопросу отработки удароопасных } \\
\text { угольных пластов короткими забоями }\end{array}$ & 7 & 13 \\
\hline $\begin{array}{l}\text { CATERPILLAR Новая струговая система Cat }{ }^{\circ} \mathrm{H} 800 \mathrm{~B} \\
\text { для разработки длинными забоями обеспечивает вы- } \\
\text { сокую производительность на очень тонких угольных } \\
\text { пластах }\end{array}$ & 7 & 12 \\
\hline
\end{tabular}

\section{ОТКРЫТЫЕ РАБОТЫ}

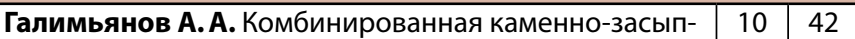
ная забойка

Ганин А. Р., Донченко Т. В., Шибанов Д. А. Развитие ряда экскаваторов класса 20-25 куб. м производства ИЗ-КАРТЭКС для горной промышленности

Глинина О.И. II Международная научно-практическая конференция «Открытые горные работы в XXI веке»: итоги работы

Добровольский А. И., Галимьянов А. А., Шевкун Е. Б., Лещинский А. В. Короткая каменно-засыпная забойка взрывных скважин

Добровольский А.И., Галимьянов А.А., Шевкун

Е.Б., Лещинский А.В. Совместная разработка сбли женных пологих каменноугольных пластов в разнопрочных и мерзлых вмещающих породах

Керопян А. М. Новое в карьерном железнодорожном транспорте

Килин Ю. А., Константинов А.В., Стариков К. А., Дорошенко Д. И., Ковалев Н. В., Думлер А. А., Шаталов В. А., Довженок А.С., Полещук М. Н. Разработка норм организации процесса «железнодорожная вскрыша» в АО «Разрез Назаровский»

Колесниченко Д.С. Увеличение интервалов замены масел на горной технике

Кузнецов В. Г., Кочетов Е. В., Кузнецов И. П. Повышение эффективности использования совместной системы карьерный экскаватор - автосамосвал при работе на увлажненных рыхлых вскрышных породах Ляшенко Павел Добывай с умом!

\section{Матва С. В., Кокин С. В., Литвин Ю.И., Протасов}

С. И., Корнев Г. Н., Федотенко В. С. Совершенствование способов буровзрывной подготовки пород на предприятиях ОАО «УК «Кузбассразрезуголь»

Нецветаев А. Г., Григорян А. А., Пружина Д. И. Оборудование и технология для безлюдной добычи угля из под бортов открытых разработок

ООО «Палл Евразия» Pall Aria Multirack - решение

для очистки сточных вод на угольном разрезе

ОАО «Междуречье», Кузбасс

\begin{tabular}{|c|c|c|}
\hline $\begin{array}{l}\text { Репин Н.Я., Ташкинов А.С., Колесников В.Ф., Про- } \\
\text { тасов С.И., Литвин О.И. Кафедре «Открытые горные } \\
\text { работы» КузГТУ - } 60 \text { лет! }\end{array}$ & 12 & 33 \\
\hline Симагаева Н. От развития к успеху & 8 & 72 \\
\hline $\begin{array}{l}\text { Щукин В.К., Зыкалин А.В. Особенности буровз- } \\
\text { рывных работ на угольных разрезах ТОО «Богатырь } \\
\text { Комир» }\end{array}$ & 12 & 18 \\
\hline $\begin{array}{l}\text { Щукин В. К., Мелехов Д.П. Трансформация тех- } \\
\text { нологий добычи угля на разрезах Экибастузского } \\
\text { месторождения, новые решения - путь к мировым } \\
\text { стандартам }\end{array}$ & 6 & 12 \\
\hline $\begin{array}{l}\text { Экскаватор Cat }{ }^{\circ} \text { 329D2 сочетает в себе конструкцию } \\
\text { мирового класса, высокую производительность, топ- } \\
\text { ливную экономичность и превосходную надежность }\end{array}$ & 4 & 42 \\
\hline
\end{tabular}

\section{НОВОСТИ ТЕХНИКИ. ГОРНЫЕ МАШИНЫ. ТРАНСПОРТ}

Алькема А. А. Качественная выемка угля с применением челноковой углерезной машины

\begin{tabular}{|l|c|c|}
\hline Глинина О.И. Польская Горная Техника - покоряем & 4 & 26
\end{tabular} земные недра

\begin{tabular}{|l|c|c|}
\hline Горячковская Анна SSAB представляет новую марку & 5 & 24
\end{tabular} высокопрочной стали Strenx

Григорьев А. А., Пудов Е. Ю., Хорешок А. А. Об

\begin{tabular}{|l|l|l|l|}
\hline Гигорьев А.А., Пудов Е.Ю., Хорешок А.А.Об & 6 & 28
\end{tabular} шнекового исполнительного органа

\begin{tabular}{|l|l|l|}
\hline Иванов Л.М. Вопросы по нормам безопасности при & 8 & 82
\end{tabular} эксплуатации механических стыковых соединений

конвейерных лент в современных условиях

\begin{tabular}{|l|l|l|}
\hline Компания Corum Рынок выбирает качество и сервис & 5 & 62 \\
\hline
\end{tabular}

\begin{tabular}{|l|l|l|}
\hline Компания ContiTech Эффективно и экономично: & 5 & 54
\end{tabular}

ContiTech представляет ленточные конвейерные сис-

темы для горнодобывающей промышленности

\begin{tabular}{|l|c|c|}
\hline Корпорация «АСИ» Учет материалов, поступающих в & 5 & 48
\end{tabular}

вагонах и выгружаемых вагоноопрокидывателем

\begin{tabular}{|l|l|l|}
\hline Кузиев Д. А., Губенко А. А., Губанов С. Г., Кузнецова & 10 & 85
\end{tabular}

А.А. Анализ жесткостных параметров пневмогидрав-

лического упругодемпфирующего устройства приво-

да ковшового ротора карьерного комбайна

Кутч Ш.М. Прибор управления marco нового

поколения

Макаров И.С. Сила партнерства - в его долгосроч-

ности и надежности

Маянская А.С. ООО «Сибэлектро»

Наливайко А.Б. Увеличение вывозки породы на 3-7\%

ОАО «Мечел» ОАО «БМК» разработало импортозаме-

щающие канаты для карьерных экскаваторов

ОАО «Электромеханика» Контроль тепловозов в

режиме реального времени

ООО «ССАБ Шведская Сталь СНГ» Отвечая на

вызовы времени. Опыт использования сталей Hardox

и Weldox для технического обслуживания оборудова-

ния на угледобывающих предприятиях Кузбасса

ООО «Стар Трак» Грузовик по расчету или как сэко-

номить миллион

\begin{tabular}{|l|l|l|}
\hline ООО «ЦГМ» С новым оборудованием - новые рекорды & 7 & 10 \\
\hline
\end{tabular}

\begin{tabular}{|l|l|l|}
\hline Першин Антон Этап разработки и апробации про- & 5 & 36
\end{tabular}

дуктов - распределённый научный центр

Примачев Ю. В., Дьяконов А. В., Роженко В.В.,

Довженок А.С. Повышение безопасности и эффек-

тивности функционирования автотранспортных

подразделений АО «СУЭК»

Пудов Е. Ю., Хорешок А. А., Животягин И.А. Про-

ектирование и производство новых конструктивных исполнений ковшей с целью импортозамещения 


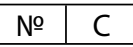

CATERPILLAR Автосамосвалы с шарнирно-сочлененной рамой новой серии С увеличивают потенциальную прибыльность благодаря сниженной продолжительности циклов, топливной эффективности, наличию автоматизированных систем и простоте в эксплуатации

\begin{tabular}{|l|c|c|}
\hline FLEXCO Europe GmbH Для идеально прямой траекто- & 8 & 87
\end{tabular} рии движения и оптимального потока материала

\section{ОХРАНА ТРУДА. БЕЗОПАСНОСТЬ. ДЕГАЗАЦИЯ}

Баркалова Н.Ю. Защита органов дыхания работников добывающих предприятий

Гак Е. И., Спельникова М. И. В чем уникальность фильтрующей полумаски Aura ${ }^{\circledR} 9300$ ? Или Aura ${ }^{\circledR}$ квинтэссенция научной мысли

Глинина О.И. II Международная научно-практическая конференция «Промышленная безопасность предприятий минерально-сырьевого комплекса в XXI веке»

ЗАО «ЗМ Россия», ГК «Восток-Сервис» Комплексный подход к защите шахтеров Каркашадзе Г.Г., Сластунов С. В., Ермак Г.П., Маза- 11 62 ник Е. В. Интенсификация дегазации угольного пласта на основе учета

Кириллов В.Ф., Чиркин А. В. Профилактика профзаболеваний шахтёров при воздействии пыли Колесниченко И.Е., Колесниченко Е. А., Артемьев В. Б., Черечукин В.Г. Физические аспекты определения потерь давления воздуха в вентиляционных трубопроводах

\section{Копылов К.Н., Смирнов О. В., Кулик А. И., Пота-}

пов П.В. Испытания автоматизированной системы акустического контроля состояния массива горных пород

Кочерга В.Н., Сытник И. В., Левчинский Г. С. Ис-

пользование подземных дегазационных установок для повышения производительности дегазационной системы шахты «Краснолиманская» и увеличения угледобычи

Пирогов А.С., Спельникова М.И. Обеспечение эффективности защиты слуха у персонала добывающих предприятий

Плаксин М.С., Родин Р. И., Рябцев А. А., Аль-

ков В. И., Леонтьева Е. В., Непеина Е. С. Гидроразрыв угольного пласта в шахтных условиях как панацея решения газовых проблем шахт (основы разработки и внедрения)

Пучков Л. А., Каледина Н. О., Кобылкин А.С., Смирнов О.В. Локальное формирование параметров вентиляции, подлежащих контролю при автоматизации проветривания

Спельникова М. И., Васильев Е. В., Булгаков С. Н.

Респираторная защита сварщика

Тайлаков О. В., Кормин А.Н., Застрелов Д. Н., Утка-

ев Е.А. Определение газоносности угольных пластов на основе исследования процессов фильтрации и диффузии метана

\section{ЭКОНОМИКА. ОРГАНИЗАЦИЯ ПРОИЗВОДСТВА.} В ПОМОЩЬГОРНЯКУ. СОЦИАЛЬНО-ЭКОНОМИЧЕСКИЙ РАЗДЕЛ. АНАЛИТИКА

Арасланов Е.Р. АО ХК «СДС-Уголь»: на предприятиях компании внедрен контроль за материальными потоками

\begin{tabular}{|l|l|l|}
\hline Артемьев В.Б., Галкин В. А., Макаров А. М. Резервы & 2 & 31
\end{tabular} повышения безопасности и эффективности производства ОАО «СУЭК» в условиях кризиса
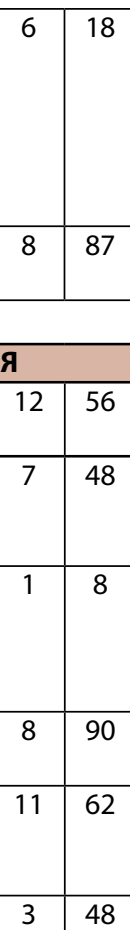

\begin{tabular}{|c|c|}
\hline 12 & 56 \\
\hline 7 & 48 \\
\hline 1 & 8 \\
\hline
\end{tabular}

\section{.}

Мухин Ф. К., Немцова Т. В., Бычков В. А., Захаров

С. И. Разработка системы оплаты труда линейных

руководителей производственных участков

Новоселов С. В. Методические аспекты расчета оптимальных параметров производства и потребления энергетических ресурсов региональным ТЭК Кемеровской области в стратегической перспективе на период 2020-2030 гг.

Новоселов С.В. Энергетическая стратегия России ЭС-2030, ее приоритеты и новые ответы внешним вызовам (аспект специфики стратегий региональных ТЭК) Ошаров А.В. Организационные и технологические решения по обеспечению жизнеспособности разреза «Изыхский»
Балашов В.Н., Ершов Р. В., Матухно А. М., Лапаева

$1 \quad 61$

О.А. Номинирование и оплата труда персонала как

службы угледобывающего предприятия

ев В. А. О структуре функционала главного механика

И.Л., Лапаева О.А. Повышение безопасности и

Буйницкий А. И., Попов Д.В., Сухарьков И.Н., Заха-

Бурцев С. В., Ефимов В.И., Ильин А. С., Попов С. М.

одиеские основы применения маржинального

разрезах «СДС-Уголь» в условиях кризиса

езопасности производства

мышленности

Галиев Ж. К., Галиева Н.В. Экономические и тех-

Дега А.Н., Дряхлов С. В., Кондауров И.Ф., Лунев

Зуев К.Н. О роли Службы внутреннего контроля и

Калачева Л.В. Методика обоснования комплекса мероприятий по стимулированию роста производиных рабочих мест в угольной отрасли

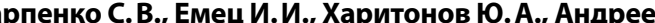
организации деятельности ремонтной службы как

саная составляющая функционала главного механика

О функционале и инструментарии директора

А. М. Подходы к повышению качества связи

Макаров А. М. Развитие функционала главного

Максимов С. Ю., Тушев А.Ю. Основные результаты деятельности ФГБУ «СОЦУГОЛЬ» в 2014 году

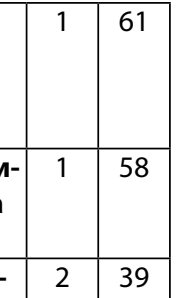

xa-

-

\begin{tabular}{l|l|l}
11 & 37
\end{tabular}

a

,

$+$

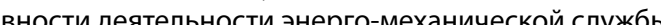




\begin{tabular}{|c|c|c|}
\hline & № & C \\
\hline $\begin{array}{l}\text { Плакиткин Ю.А., Плакиткина Л.С., Дьяченко К.И. } \\
\text { Формирование цен на уголь: отечественная и миро- } \\
\text { вая практика }\end{array}$ & 1 & 52 \\
\hline $\begin{array}{l}\text { Попов В.Н., Грибин Ю.Г., Ефимова Г. А., Гаркавенко } \\
\text { А.Н., Семина Л. Ю. Методические рекомендации по } \\
\text { повышению эффективности управления материаль- } \\
\text { ными и трудовыми ресурсами в условиях модерни- } \\
\text { зации и инновационного развития угледобывающих } \\
\text { организаций }\end{array}$ & 6 & 48 \\
\hline $\begin{array}{l}\text { Приступа Ю.Д., Шишкина С. В., Борблик Е.А., } \\
\text { Смолин А.В. Подготовка персонала при реализации } \\
\text { комплексного подхода к обеспечению безопасности } \\
\text { в Погрузочно-транспортном управлении ОАО «СУЭК- } \\
\text { Кузбасс» }\end{array}$ & 11 & 54 \\
\hline $\begin{array}{l}\text { Рожков А. А., Карпенко М.С. Управление энергосбе- } \\
\text { режением на углепромышленных предприятиях на } \\
\text { основе проектно-процессного подхода }\end{array}$ & 10 & 54 \\
\hline $\begin{array}{l}\text { Соколовский А. В., Черских О.И., Каинов А.И., Пи- } \\
\text { калов В.А. Выбор режима горных работ на разрезе }\end{array}$ & 10 & 77 \\
\hline $\begin{array}{l}\text { Таразанов И.Г. Итоги работы угольной промышлен- } \\
\text { ности России за январь-декабрь } 2014 \text { года }\end{array}$ & 3 & 56 \\
\hline $\begin{array}{l}\text { Таразанов И.Г. Итоги работы угольной промышлен- } \\
\text { ности России за январь-март } 2015 \text { года }\end{array}$ & 6 & 32 \\
\hline $\begin{array}{l}\text { Таразанов И.Г. Итоги работы угольной промышлен- } \\
\text { ности России за январь-июнь } 2015 \text { года }\end{array}$ & 10 & 60 \\
\hline $\begin{array}{l}\text { Чернов А.И., Пахомов А.А., Фомина Т. В., Вьюнов } \\
\text { Е. М., Лапаева О.А. Результаты и оплата труда управ- } \\
\text { ленческого персонала угледобывающего предпри- } \\
\text { ятия }\end{array}$ & 4 & 59 \\
\hline $\begin{array}{l}\text { Шаклеин С. В., Рожков А. А., Рогова Т. Б. Маркшей- } \\
\text { дерско-геологическое обеспечение подготовки пред- } \\
\text { приятий к IPO (первоначальному размещению акций) }\end{array}$ & 1 & 47 \\
\hline $\begin{array}{l}\text { Шаповаленко Г. Н., Тесемников С. В., Косьяненко } \\
\text { Э.А., Довженок А.С. Развитие технологии и органи- } \\
\text { зации производства в условиях кризиса }\end{array}$ & 2 & 36 \\
\hline $\begin{array}{l}\text { Шестаков И.Г., Емец И.И., Ломовцев А. О., Бычков } \\
\text { В.В., Шивырялкина О.С. Совершенствование опла- } \\
\text { ты труда линейных руководителей Разрезоуправле- } \\
\text { ния «Новошахтинское» }\end{array}$ & 4 & 57 \\
\hline
\end{tabular}

\begin{tabular}{|c|c|c|}
\hline \multicolumn{3}{|l|}{ ВОПРОСЫ КАДРОВ } \\
\hline Богатство недр моей страны & 7 & 60 \\
\hline $\begin{array}{l}\text { Всероссийский конкурс «Новая идея» на лучшую } \\
\text { научно-техническую разработку среди молодежи } \\
\text { предприятий и организаций топливно-энергетичес- } \\
\text { кого комплекса }\end{array}$ & 2 & 46 \\
\hline $\begin{array}{l}\text { Всероссийский Чемпионат по решению топливно- } \\
\text { энергетических кейсов: инженерные кейсы входят в } \\
\text { моду }\end{array}$ & 2 & 47 \\
\hline $\begin{array}{l}\text { Первый шаг к победам инженеров. Дан старт Всерос- } \\
\text { сийского Чемпионата по решению топливно-энерге- } \\
\text { тических кейсов }\end{array}$ & 4 & 66 \\
\hline $\begin{array}{l}\text { Студенты-целевики «СДС-Угля» - победители } \\
\text { отборочного этапа Всероссийского Чемпионата по } \\
\text { решению кейсов в области горного дела }\end{array}$ & 4 & 67 \\
\hline $\begin{array}{l}\text { Финал Всероссийского чемпионата по решению } \\
\text { топливно-энергетических кейсов }\end{array}$ & 7 & 54 \\
\hline
\end{tabular}

\section{РЕСУРСЫ. ПЕРЕРАБОТКА УГЛЯ}

\begin{tabular}{|l|l|l|}
\hline Антипенко Л. А. К вопросу о современных технологи- & 12 & 68
\end{tabular} ях переработки и обогащения угля

Булавин Д. О., Козлов В. В. Современные процессь эмульгирования и коалесценции в аппаратах-эмульгаторах
ЗАО «Праксис Инжиниринг» Биметаллические молотки и била с повышенным эксплуатационным ресурсом для всех типов дробильного оборудования роторного типа

Кириллов К. М., Козлов В. А., Чернышева Е.Н. Инновационная сушка «Кронос». Глубокое нетермическое обезвоживание угля и минералов

Масла ЛУКОЙЛ для угольной отрасли: эффективное импортозамещение

Переладов Сергей Эффективный подбор смазочных материалов - ключ к успеху

Пресс-служба ОАО ХК «Якутуголь» На Эльгинском

угольном комплексе обогащен первый миллион тонн угля

Садов А.П., Костеренко В.Н., Тайлаков О.В.,

Уткаев Е. А., Застрелов Д.Н., Смыслов А. И. Опыт использования вентиляционного метана в качестве дополнительного топлива для двигателей внутреннего сгорания

Саркисов Г.Р. Способ и устройство сухого обогащения угольных штыбов

\begin{tabular}{|l|l|l|}
\hline Степанов С. Г., Исламов С. Р. Проблемы производства & 7 & 50
\end{tabular} жидкого топлива из угля

Тюльнин В.А. Технология получения и свойства композиционных материалов на основе углерода

фуллереновых форм шунгитовых пород

\begin{tabular}{|l|l|l|}
\hline Чем заменить импорт обогатительного оборудования & 4 & 68 \\
\hline
\end{tabular}

\begin{tabular}{|l|l|l|}
\hline Чернышева Е.Н. Опыт применения тяжелосредных & 2 & 58
\end{tabular}

гидроциклонов большого диаметра на углеобогати-

тельных фабриках

\begin{tabular}{|l|l|l|}
\hline XVIII Международный Конгресс по обогащению угля & 2 & 56 \\
\hline
\end{tabular}

\section{НЕДРА. ГЕОЛОГИЯ}

Гурин В.П., Сергеев А. В., Деветьярова Е. А., Полухин В.А., Гурин В. В. Управление охраной горных выработок

Демин В.Ф., Демина Т. В., Муртазин С. Д. Аналитическое моделирование деформаций приконтурных пород вблизи горных выработок

\begin{tabular}{|l|l|l|}
\hline Ефимов В. И., Сидоров Р. В., Корчагина Т. В. Актуаль- & 4 & 72
\end{tabular} ные вопросы проектирования консервации (ликвидации) неэффективных угледобывающих производств на примере шахт Прокопьевско-Киселевского района Кузбасса

Ефимов В.И., Сидоров Р. В., Корчагина Т.В.

К вопросу проектирования консервации (ликвида-

ции) неэффективных угледобывающих производств Ефимов В.И., Лермонтов Ю.С., Сидоров Р. В., Корчагина Т.В. Мониторинг ликвидируемых шахт Кузнецкого угольного бассейна Инновационные направления в проектировании горнодобывающих предприятий

\begin{tabular}{|l|l|l|}
\hline Нецветаев А. Г., Григорян А. А., Пружина Д.И. Алго- & 1 & 25
\end{tabular} ритм расчета геомеханических параметров, обеспечивающих безопасность технологии безлюдной добычи угля с применением КГРП

Пак Г. А., Долгоносов В.Н. Шаги обрушения основной кровли и прогноз газовыделения на шахтах Карагандинского бассейна

Ремезов А. В., Климов В. В. Исследование влияния опорного давления от очистного забоя и зон ПГД на горные выработки, оконтуривающие выемочный столб Сидоров Р. В., Корчагина Т. В., Новиков Я. А. Обоснование окончательных границ санитарно-защитной зоны промышленного объекта и производства 


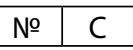

Смирнов О. В., Кулик А. И., Лапин Е. А. Прогноз геологических нарушений по параметрам акустического сигнала

Тайлаков О.В., Коровин Д.С., Макеев М. П., Соколов С.В. Алгоритмическое и программное обеспечение с применением беспилотных летательных аппаратов для оценки остатков угля на открытых складах

\section{ЭКОЛОГИЯ}

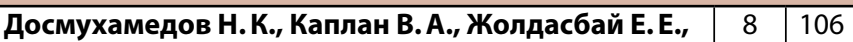

Досмухамедов Д.Н., Любомирский И. Разработка

способа очистки отходящих газов тепловых угольных

электростанций от серы

Ефимов В.И., Сидоров Р. В., Корчагина Т. В., Дятло-

ва Г. А. Воздействие подземной добычи каменного

угля на качество атмосферного воздуха (на примере

ООО «Шахта Листвяжная»)

Ефимов В. И., Сидоров Р. В., Корчагина Т. В. Об-

разование отходов производства от предприятий

угольной отрасли на территории Кемеровской

области

Зеньков И. В., Нефедов Б. Н., Барадулин И. М.,

Вокин В.Н., Кирюшина Е. В. Возникновение и

опасность последствий оползней при деформации

старовозрастных породных отвалов

Зеньков И. В., Нефедов Б. Н., Юронен Ю. П.,

Заяц В. В., Вокин В.Н., Кирюшина Е. В. Информа-

ционное обеспечение мониторинга лесной рекуль-

тивации по данным дистанционного зондирования

и полевых экспедиций на отработанном участке

Ирша-Бородинского буроугольного месторождения

Зеньков И. В., Нефедов Б. Н., Юронен Ю.П.,

Заяц В. В., Вокин В.Н., Кирюшина Е. В. Информа-

ционное обеспечение мониторинга лесной рекуль-

тивации по данным дистанционного зондирования

и полевых экспедиций на отработанном участке

Ирша-Бородинского буроугольного месторождения

Зеньков И. В., Нефедов Б. Н., Юронен Ю. П., Бель-

кович Л. И., Молчанов Ю. А., Вокин В.Н., Кирю-

шина Е. В. Информационное обеспечение оценки наземной экосистемы при разработке Азейского буроугольного месторождения с применением дистанционных средств зондирования Земли

Зеньков И. В., Нефедов Б. Н., Юронен Ю. П., Вокин В.Н., Кирюшина Е. В. Разработка информационного обеспечения мониторинга экосистемы на породных отвалах угольного разреза «Канский» с применением средств дистанционного зондирования

Зеньков И. В., Нефедов Б. Н., Барадулин И. М., Кирюшина Е. В., Вокин В.Н. Результаты геоэкологического обследования породных отвалов на территории Ирша-Бородинского буроугольного месторождения

Зеньков И. В., Нефедов Б. Н., Школьный И.А., Юронен Ю. П. Результаты геоэкологического обследования породных отвалов на территории отработанной части Переяславсокого буроугольного месторождения с использованием средств дистанционного зондирования Земли

Зеньков И. В., Нефедов Б. Н., Юронен Ю. П., Бара-

дулин И. М., Кирюшина Е. В., Вокин В. Н. Результаты горно-экологического мониторинга техногенных ландшафтов на отработанной части Черногорского угольного месторождения с применением средств дистанционного зондирования

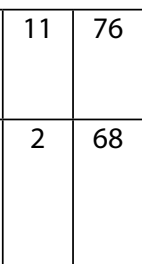

Сидоров Р. В., Корчагина Т. В. Комплексная оценка эколого-экономического риска воздействия техногенных массивов угледобывающих предприятий на компоненты окружающей среды как основа управления риском

Сидоров Р. В., Степанов Ю. А., Корчагина Т. В., Марченко В. А. Моделирование зон загрязнения окружающей среды от техногенного воздействия с использованием ГИС-технологий

Сидоров Р. В., Корчагина Т. В. Обоснование необходимости совершенствования методологии комплексной оценки техногенного воздействия горного производства на окружающую среду

Сидоров Р. В., Степанов Ю. А., Корчагина Т. В., Марченко В.А. Прогнозирование экологической ситуации в угледобывающих регионах

Тургенева Л.А., Манаков Ю.А. Природоохранные мероприятия на угольных предприятиях АО ХК «СДСУголь»

\section{ХРОНИКА. ВЫСТАВКИ. ЗА РУБЕЖОМ}

Глинина О.И. Итоговый обзор 19-й Международной выставки оборудования и технологий для добычи и обогащения полезных ископаемых Mining World Russia-2015

Зарубежная панорама - №2 - 80; №3 - 86; №4 - 86; №7 - 78

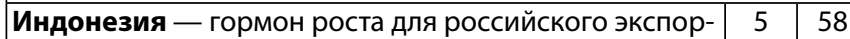
тера

Инновационные направления в проектировании горнодобывающих предприятий Итоги VI Международной конференции «Железнодорожные перевозки горно-металлургических грузов РФ» МАЙНЕКС Россия 2014. Новые рубежи и вызовы в минерально-сырьевом комплексе России

Обозначены векторы развития российской горнорудной промышленности

Перечень статей, опубликованных в журнале «Уголь» $12 \quad 81$ в 2015 году

Хроника. События. Факты. Новости — №1 - 36; №2 - 17; №3 - 38; №4 - 44; №5 - 60; №6 - 6; №7 - 24 ; №8 -78 ;

№9 - 72; №10 - 84; №11 - 8; №12 - №12 - 47

V Международная научно-практическая конференция «Техгормет-21 век»

XIII Московский международный энергетический форум «ТЭК России в XXI веке»

XVII Международная научно-практическая конференция «Энергетическая безопасность России: новые подходы к развитию угольной промышленности» XVIII Международная выставка-ярмарка «ЭкспоУголь-2015»

\section{УГОЛЬ РОССИИИ И МАЙНИНГ}

Глинина О.И.«Уголь России и Майнинг» В новом формате

Глинина О.И. XXII Международная специализированная выставка «Уголь России и Майнинг», VI Специализированная выставка «Охрана, безопасность труда и жизнедеятельности» и I Международная специализированная выставка «Недра России»: итоги, события, факты. Для всех отраслей горнодобывающей промышленности

Приветствия участникам выставки «Уголь России и Майнинг» от губернатора Кемеровской области А.Г. Тулеева и председателя Совета народных депутатов Кемеровской области Е. В. Косьяненко

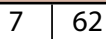

\begin{tabular}{|c|c|}
\hline 6 & 65 \\
\hline 12 & 78 \\
\hline 1 & 78 \\
\hline 12 & 77 \\
\hline 12 & 81 \\
\hline $17 ;$ & \\
\hline $78 ;$ & \\
\hline 2 & 74 \\
\hline 6 & 66 \\
\hline 7 & 6 \\
\hline 7 & 5 \\
\hline 12
\end{tabular}

\begin{tabular}{|c|c|c|}
\hline & 3 & 15 \\
\hline H- $^{-}$ & 8 & 94 \\
\cline { 2 - 3 } & 10 & 46 \\
\cline { 2 - 3 } & 11 & 23 \\
\hline кты. & & \\
\hline н- & 4 & 25 \\
& 5 & 7 \\
\hline
\end{tabular}


XX Международная специализированная выставка технологий горных разработок, обогащения, выемочной и подъемно-транспортной техники «Уголь России и майнинг-2015», VI Международная специализированная выставка «Охрана, безопасность труда и жизнедеятельности», I Международная специализированная выставка «Недра России»

\section{СТРАНИЦЫ ИСТОРИИ. РЕЦЕНЗИИ. ОТКЛИКИ}

80-летие рекорда Алексея Стаханова

\begin{tabular}{|l|c|c|}
\hline К 100-летию Шахтерского маршала. Романов Влади- & 6 & 82 \\
\hline
\end{tabular} мир Павлович (1915 - 2002)

Полезное пособие по оценке освоения курса дисциплин горной технологии в форме обучающих тестов

\section{К 70-ЛЕТИЮ ПОБЕДЫ}

В труде как в бою... (из воспоминаний Б. Ф. Братченко, министр угольной промышленности СССР, 1965-1985 г2.)

Заньков А.П. Подвиг шахтеров Приморья в годы Великой Отечественной войны

$\mathbf{7 0}$ лет со Дня Победы в Великой Отечественной войне 1941-1945 гг.

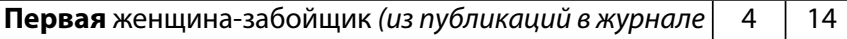
«Уголь» №5-2005)

\begin{tabular}{|l|l|l|l|}
\hline Подвиг солдата, увековеченный в бронзе (nо мате- & 4 & 16
\end{tabular} риалам статьи Олега Назарова)

Поклонимся великим тем годам!

Приближая Победу: взгляд СКвозь годы (nо мате-

риалам воспоминаний М.И. Северина, управляющий

трестом «Гуковуголь», 1941-1945 г2.)

\section{КУЗГТУ - 65 ЛЕТ}

Баканов А. А. Об Институте информационных технологий, машиностроения и автотранспорта

Голофастова Н. Н. КузГТУ 65 лет на службе экономики Кузбасса

Исмагилов 3. Р., Тайлаков О. В., Теряева Т.Н., Хямяляйнен В.А., Мурко В.И., Лазаренко С. Н., Бо гомолов А. Р., Григашкина С. И., Шикина Н. В., Михайлова Е.С. Разработка эффективности технологии снижения загрязненности дымовых газов тепловых электростанций угольной генерации

История создания Кемеровского горного института

Ковалёв В.А. КузГТУ — кузница кадров для предприятий региона

Ковалёв В. А., Макин М. А., Першин В. В. Становле-

ние и развитие кафедры «Строительство подземных сооружений и шахт»

Ковалёв В. А., Хорешок А. А., Герике Б.Л. Диагностика технического состояния проходческих комбайнов избирательного действия

Копытов А. И., Першин В. В., Войтов М.Д., Вети

А. А. Разработка защитных устройств, технологии их сооружения и демонтажа при углубке вертикальных стволов

Поздравления КузГТУ с юбилеем от губернатора Кемеровской области А.Г. Тулеева, генерального директора ОАО «СУЭК-Кузбасс» Е.П. Ютяева, генерального директора АО ХК «СДС-Уголь» Ю.С. Дерябина

Семыкина И. Ю. Институт энергетики КузГТУ: наука для практиков

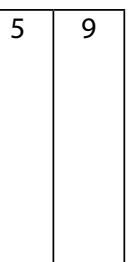

11

\begin{tabular}{|c|c|c|}
\hline 4 & 11 \\
\hline 4 & 18 \\
\hline 4 & 5 \\
\hline 4 & 14 \\
\hline 4 & 16 \\
\hline 4 & 6 \\
\hline 4 & 12 \\
\hline & \\
\hline
\end{tabular}

\begin{tabular}{|c|c|c|}
\hline 4 & 11 \\
\hline 4 & 18 \\
\hline 4 & 5 \\
\hline 4 & 14 \\
\hline 4 & 16 \\
\hline 4 & 6 \\
\hline 4 & 12 \\
\hline & \\
\hline
\end{tabular}

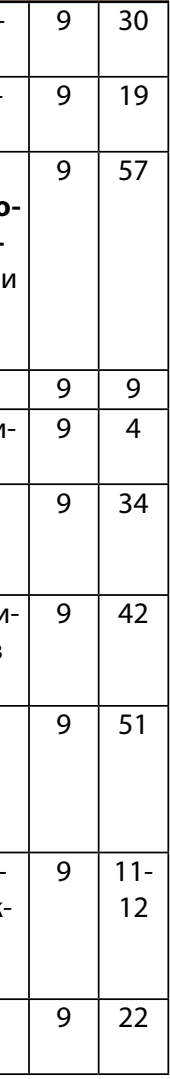

Тайлаков О. В., Григашкина С. И. Международная деятельность Кузбасского государственного технического университета имени Т. Ф. Горбачева

Тациенко В.П., Шевченко Л. А. Подготовка кадров высшей квалификации по промышленной безопасности и охране труда для опасных производственных объектов кузбасса

Хорешок А. А. Горный институт — кузница инженерных кадров для угольной отрасли Кузбасса

Хямяляйнен В. А., Иванов В. В., Пашин Д.С. Общая сейсмическая обстановка и сейсмоопасность шахтных полей в условиях Кузбасса

Черкасова Т. Г., Папин А. В., Неведров А. В. Роль Института химических и нефтегазовых технологий КузГТУ в развитии углехимии в Кузбассе

Шевченко Л.А. О физической модели газодинамики угольного массива в зонах влияния скважин

\section{ЖУРНАЛУ «УГОЛЬ» - 90 ЛЕТ}

Гринько Н. К. Поступательное движение

Задачи журнала «Уголь» при реорганизации его в

печатный орган каменноугольной промышленности страны (исторический экскурс)

Нуждихин Г.И. Наивысший подъем

Таразанов И.Г. 90 лет вместе с читателями (к юбилею 10 6 журнала «Уголь»

\section{ЮБИЛЕИ}

\section{Антипенко Лина Александровна}

(к 85-летию со дня рождения)

Артемьев Владимир Борисович

(к 50-летию со дня рождения)

Бакарак Джон Пол Леонард

(к 80-летию со дня рождения)

\section{Баскаков Владимир Петрович}

(к 60-летию со дня рождения)

Зайденварг Валерий Евгеньевич

к 75-летию со дня рождения)

Казаков Владимир Борисович

(к 75-летию со дня рождения)

Качармин Семен Дмитриевич

(к 95-летию со дня рождения)

Колодяжный Григорий Иванович

(к 80-летию со дня рождения)

Кравчук Игорь Леонидович

(к 50-летию со дня рождения)

Краснянский Георгий Леонидович

(к 60-летию со дня рождения)

Курдин Михаил Петрович

(к 80-летию со дня рождения)

Липилин Степан Захарович

(к 100-летию со дня рождения)

Логов Александр Борисович

(к 70-летию со дня рождения)

Навитний Аркадий Михайлович

(к 80-летию со дня рождения)

Никишичев Сергей Борисович

(к 40-летию со дня рождения)

Новоселов Сергей Вениаминович

(к 55-летию со дня рождения)

Панфилов Феодосий Александрович

(к 60-летию со дня рождения)

Певзнер Леонид Давидович

(к 75-летию со дня рождения)

\begin{tabular}{|c|c|}
\hline 9 & 16 \\
\hline 9 & 61 \\
\hline 9 & 13 \\
\hline 9 & 48 \\
\hline 9 & 27 \\
\hline 9 & 39 \\
\hline
\end{tabular}

\begin{tabular}{|c|c|c|}
\hline & 10 & 16 \\
\hline в & 10 & 14 \\
& 10 & 18 \\
\hline
\end{tabular}

\begin{tabular}{|c|c|c|}
\hline & 7 & 76 \\
\hline & 5 & 74 \\
\hline & 3 & 88 \\
\hline & 4 & 83 \\
\hline & 4 & 84 \\
\hline & 10 & 88 \\
\hline & 2 & 84 \\
\hline & 1 & 88 \\
\hline & 2 & 83 \\
\hline & 9 & 91 \\
\hline & 1 & 86 \\
\hline & 6 & 81 \\
\hline & 3 & 88 \\
\hline & 9 & 92 \\
\hline & 6 & 81 \\
\hline & 4 & 85 \\
\hline & 8 & 116 \\
\hline & 4 & 85 \\
\hline & & \\
\hline & &
\end{tabular}




\begin{tabular}{|l|c|c|c|}
\cline { 2 - 4 } \multicolumn{2}{l|}{} & № & С \\
\hline \begin{tabular}{|l|c|c|} 
Першин Владимир Викторович \\
(к 65-летию со дня рождения)
\end{tabular} & 4 & 83 \\
\hline $\begin{array}{l}\text { Пикалов Вячеслав Анатольевич } \\
\text { (к 50-летию со дня рождения) }\end{array}$ & 2 & 83 \\
\hline $\begin{array}{l}\text { Попов Владимир Николаевич } \\
\text { (к 70-летию со дня рождения) }\end{array}$ & 1 & 87 \\
\hline $\begin{array}{l}\text { Хамлатов Михаил Иванович } \\
\text { (к 80-летию со дня рождения) }\end{array}$ & 2 & 82 \\
\hline $\begin{array}{l}\text { Шкундин Семён Захарович } \\
\text { (к 70-летию со дня рождения) }\end{array}$ & 8 & 115 \\
\hline
\end{tabular}

\title{
НЕКРОЛОГИ
}

Агапов Александр Евгеньевич

(22.07.1961 - 25.08.2015)

\begin{tabular}{|c|c|c|}
\hline & № & $\mathrm{C}$ \\
\hline \begin{tabular}{|l|} 
Виснап Альфред Августович \\
$(06.05 .1922-15.03 .2015)$
\end{tabular} & 4 & 88 \\
\hline \begin{tabular}{|l|} 
Галазов Руслан Алексеевич \\
$(03.11 .1931-11.03 .2015)$ \\
\end{tabular} & 6 & 84 \\
\hline Дьяков Юрий Иванович (30.03.1942 - 31.10.2015) & 12 & 88 \\
\hline \begin{tabular}{|l|} 
Кондрашин Юрий Андреевич \\
$(14.01 .1947-19.09 .2015)$ \\
\end{tabular} & 10 & 92 \\
\hline $\begin{array}{l}\text { Крутилин Владимир Иванович } \\
(15.09 .1931-18.10 .2015)\end{array}$ & 11 & 87 \\
\hline \begin{tabular}{|l|} 
Липилин Степан Захарович \\
$(09.07 .1915-12.11 .2015)$ \\
\end{tabular} & 12 & 87 \\
\hline Панин Иван Михайлович (08.01.1918-21.10.2015) & 11 & 88 \\
\hline $\begin{array}{l}\text { Шибаев Евгений Васильевич } \\
(17.04 .1934-11.03 .2015)\end{array}$ & 7 & 80 \\
\hline
\end{tabular}

\section{НЕКРОЛОГ}

\section{лИПИЛИн Степан Захарович}

\author{
(09.07.1915 - 12.11.2015 гг.)
}

12 ноября 2015 2. в возрасте 100 лет ушел из жизни известный организатор угольной промышленности СССР, горный инженер-шахтостроитель, Заслуженный шахтер Российской Федерации Степан Захарович Липилин.

Степан Захарович родился в Ростове-на-Дону. В 1936 г. окончив с отличием горно-металлургический техникум, поступил в Московский горный институт им. Сталина. Защитил диплом 21 июня 1941 г. по специальности «горный инженер-шахтостроитель».

Началась война, и вместо Донбасса Степан Захарович поехал на Урал, на Дегтярский рудник, где он работал помощником начальника участка по углубке ствола. В октябре 1941 г. был призван в армию, закончил пулеметно-минометное военное училище, был командиром взвода курсантов.

Когда освободили Донбасс, вышло постановление Государственного комитета обороны об отзыве из Красной Армии группы горных инженеров, в том числе и С. 3. Липилина, для восстановления шахт Донбасса. Работал старшим районным инженером, а в 1947 г. был назначен начальником сектора по эксплуатации в отделе по Ворошиловоградской и Ростовской областям Наркомугля.

В 1950 г. по личной просьбе был направлен в Донбасс, на отстающее шахтоуправление № 10 им. Володарского треста «Свердловуголь» начальником шахтоуправления. Проявив незаурядные организаторские и профессиональные способности, он сделал все возможное для повышения дисциплины и выполнения плана по добыче и другим показателям. Дважды шахтоуправление получало переходящее Красное знамя Минуглепрома СССР и ЦК профсоюза угольщиков и постепенно трест «Свердловуголь» вышел на первое место по производственным показателям. В 1952 г. С.3. Липилина назначили управляющим треста.
За девять лет его работы управляющим было построено хозяйственным способом пять дополнительных шахт. В 1960 г. трест стал рентабельным - единственным в Донбассе. В 1957 г. Степан Захарович был награжден орденом Трудового Красного Знамени.

В 1961 г. С. З. Липилина назначили заместителем, затем главным инженером Главного управления угольной и торфяной промышленности Украинского Совнархоза, а в 1965 г. пригласили работать в Минуглепром СССР — заместителем, затем главным инженером производственных, технологических управлений. Все годы работы в министерстве Степан Захарович непосредственно занимался развитием Донбасса и в целом угольной промышленностью Украины, имел тесную связь с руководителями комбинатов, объединений и отдельных крупных шахт.

За многолетний труд и заслуги в развитии угольной промышленности Степан Захарович Липилин награжден орденами и медалями.

\section{Работники угольной промышленности, горнотехническая общественность, друзья и соратники скорбят по случаю смерти Степана Захаровича. Светлая память о нем навсегда останется в наших сердцах.}




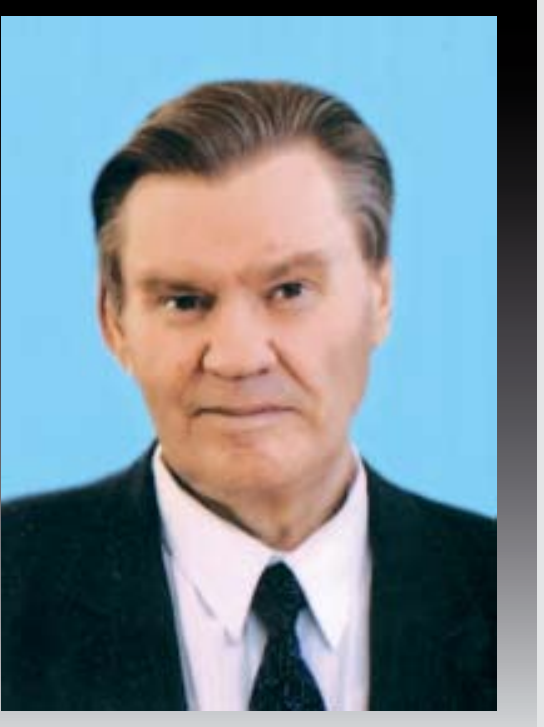

\title{
ДьяКОВ Юрий Иванович
}

\author{
(30.03.1942-31.10.2015 rг.)
}

\begin{abstract}
31 октября 2015 г. на 74 году ушел из жизни один из крупных, талантливых организаторов и руководителей угольной промышленности Кузбасса, Лауреат премии Совета Министров СССР, Почётный горняк России, кавалер медали «За особый вклад в развитие Кузбасса» трех степеней Юрий Иванович Дьяков.
\end{abstract}

Юрий Иванович родился в г. Новосибирске. В 1967 г. окончил Кузбасский политехнический институт по специальности «Горный инженер-маркшейдер», в 1975 г. с отличием окончил Новосибирскую высшую партийную школу. Трудовую деятельность в угольной отрасли Юрий Иванович начал подземным горнорабочим, затем инженерно-техническим работником на шахтах «9-15» треста «Анжероуголь» и «Ягуновская» треста «Кемеровоуголь».

С 1968 г. Юрий Иванович был на партийной работе инструктором, заведующим промышленно-транспортным отделом Рудничного райкома КПСС г. Кемерово. После окончания Высшей партийной школы он был направлен в Кемеровский обком партии, где начал трудиться инструктором, затем заместителем заведующего отделом угольной промышленности, первым секретарем Рудничного райкома партии г. Кемерово, заведующим социально-экономическим отделом Кемеровского обкома КПСС.

В 1994 г. его пригласили на работу в ОАО ХК «Кузбассразрезуголь», где он проработал в течение шести лет вицепрезидентом по социальным вопросам, являлся председателем Советов директоров ОАО «Разрез Калтанский» и ОАО «Разрез Осинниковский».

С 2000 г. до выхода на пенсию Юрий Иванович трудовую деятельность продолжил в Департаменте топливноэнергетического комплекса Администрации Кемеровской области - начальником отдела, начальником управления социально-экономического анализа и прогноза, начальником департамента.

Работая в областном комитете партии и администрации области, Юрий Иванович принимал непосредственное участие в подготовке аналитических материалов, предложений по стратегии развития угольной промышленности Кузбасса с выездом в ЦК КПСС, Совет Министров СССР, Минуглепром СССР, Минэнерго РФ.

После выхода на пенсию в 2004 г. Юрий Иванович несколько лет работал советником заместителя губернатора Кемеровской области по ТЭК. В эти годы им была проведена большая работа по сбору и обобщению архивных материалов по угольной промышленности Кузбасса, которые стали основой для составления угольной летописи края. Авторский коллектив двухтомного историко-документального исследования «Угольный Кузбасс: страницы истории», «Угольный Кузбасс: история шахтерского труда в достижениях и рекордах» под руководством Ю.И. Дьякова был награжден Дипломом Администрации Кемеровской области за I место в конкурсе «Лучшая монография 2007 года» в номинации «Гуманитарные науки».

1 марта 2013 г. Юрий Иванович Дьяков был избран на должность директора Фонда «Шахтерская память» им. В.П. Романова. Создание Фонда происходило при его непосредственном содействии, поэтому, став директором, он отдавал остаток всех своих творческих и физических сил, уникальный талант исследователя, летописца-историка на благо деятельности Фонда «Шахтерская память», направленной на реализацию социальных программ, оказание благотворительной и материальной помощи остронуждающимся ветеранам-угольщикам. Особенно много сил и энергии Юрий Иванович отдавал сохранению памяти истории развития Кузнецкого угольного бассейна и имен выдающихся угольщиков.

Добросовестный, многолетний труд и заслуги Юрия Ивановича Дьякова отмечены орденом «Знак Почета», знаком «Шахтерская слава» трех степеней, золотыми знаками «Горняк России», «Шахтерская доблесть», орденом «Знак почета», медалями: «За особый вклад в развитие Кузбасса» трех степеней, «За веру и добро», «Ветеран труда», «За доблестный труд в ознаменование 100-летия со дня рождения В.И. Ленина», «70 лет Кемеровской области».

Память озамечательном человеке, верном товарище и друге, Юрии Ивановиче Дьякове навсегда сохранится в наших сердцах.

Н. П. Неворотова, С. И. Погребных, М.И. Найдов, В. И. Прозоров, В.Н. Катриченко, В.Н. Коровицын, Л. З. Филимонов, В. Е. Брагин, И. В. Москаленко, Н. С. Приезжев, А.Г. Шварченко, Л. А. Западинский

Редколлегия и редакция журнала «Уголь» разделяют боль тяжелой утраты и выражают искреннее соболезнование родным и близким Юрия Ивановича Дьякова. Неоценим его вклад в развитие угольной промышленности Кузбасса. 


\section{Дальневосточного леопарда назвали в честь губернатора Кузбасса}

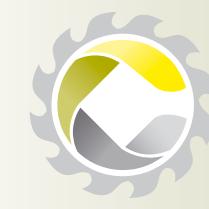

По результатам конкурса, прошедшего среди сотрудников $\mathrm{AO}$ «Сибирская угольная энергетическая компания» (СУЭК) и членов их семей, было принято решение назвать одного из леопардов, обитающего в приморском национальном парке «Земля леопарда» Аманом - в честь губернатора Кемеровской области Амана Тулеева.

Право дать имя леопарду Leo 42M CУЭK получила по результатам благотворительного аукциона, прошедшего в сентябре 2015 г. в ходе Дальневосточного экономического форума. Бережное отношение к окружающей среде - один из базовых приоритетов деятельности $\mathrm{AO}$ «СУЭК», поэтому компания деятельно откликнулась на возможность поддержать сохранение природы парка «Земля леопарда» В Приморском крае, где работает несколько предприятий компании.

Руководство СУЭК приняло решение провести конкурс среди сотрудников и членов их семей на лучшее имя для леопарда. Для участия в конкурсе было подано несколько сотен заявок. Работники предприятий СУЭК предлагали различные имена, среди которых: Забой, Уголек, Стаханов, Ротор, Ургал, Счастливчик, Олимпий и другие. Однако самым распространенным оказалось предложение назвать леопарда Аманом в честь губернатора Кузбасса. Все, кто предлагал это имя, объясняли свой выбор большим вкладом Амана Тулеева в развитие угольной промышленности и региона в целом. «Аман Гумирович - особенный человек для всей угольной отрасли нашей страны, - комментирует сделанный выбор пресс-служба АО «СУЭК», - Во многом благодаря его вере в великое предназначение российского угля, его большой многолетней работе российская угольная промышленность смоглавозродиться на перепутье XX ХXXI веков и сегодня продолжает дальнейшее развитие».

По мнению сотрудников национального парка «Земля леопарда», появление у Кемеровской области «своего» леопарда выгодно расширит границы распространения информации о самой редкой крупной кошке мира. Кроме того, с именем человека, возглавляющего рейтинг губернаторов России, этому зверю обеспечено уважение тысяч жителей Кузбасса. И хотя с учетом значительной площади ареала этих хищников помочь одной конкретной кошке достаточно сложно, первый шаг поддержки всей популяции редкого зверя уже был сделан активным распространением информации о леопарде. Благодаря конкурсу и новому имени сотни человек впервые узнали о существовании в России популяции столь уникального животного, и это только начало сотрудничества между новыми хранителями леопарда и национальным парком.

Леопард Аман, хранителем которого стало АО «СУЭК», самец дальневосточного леопарда, сейчас ему около трёхчетырёх лет, что означает недавнее вступление животного во взрослую самостоятельную жизнь, освоение новых территорий и собственных возможностей. Он обитает на границе с Китаем. Согласно снимкам, сделанным на территории национального парка «Земля леопарда», он изредка покидает российские леса, любит передвигаться по подведомственным ему местам и лишь несколько раз был замечен в КНР.
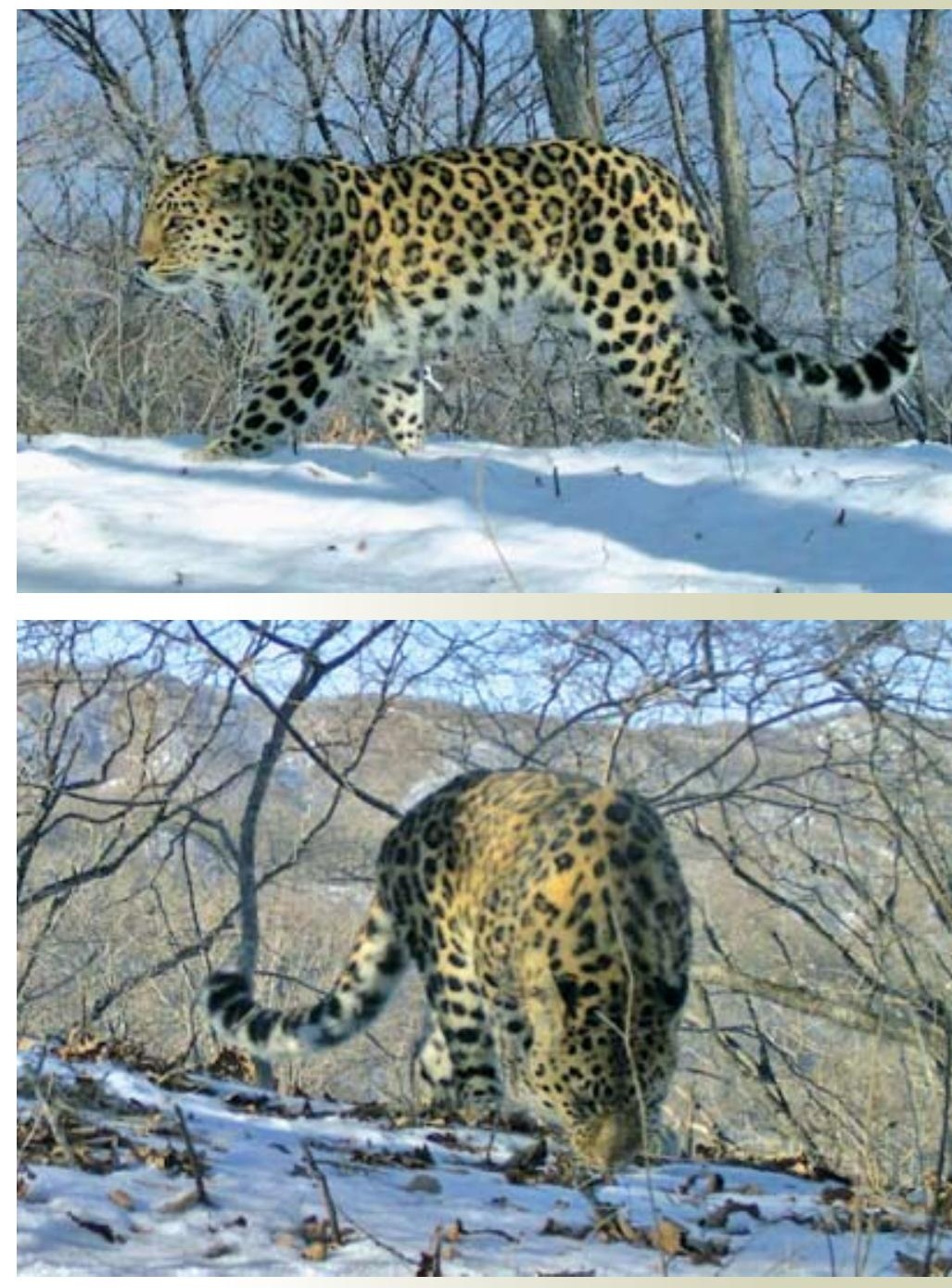

Дальневосточный леопард - одно из редчайших в мире животных на сегодняшний день, находящийся на грани вымирания. По оценке специалистов, в конце XX века численность леопардов снизилась до критической отметки - 3035 особей в мире.

Ситуацию удалось изменить, когда в 2011 г. леопард был взят под защиту. С целью изучения, сохранения и восстановления популяции в России создано АНО «Дальневосточные леопарды». А в 2012 г. постановлением Правительства Российской Федерации в Приморье был образован национальный парк «Земля леопарда». Проект по сохранению редчайшей дикой кошки на планете находится под патронажем руководителя Администрации Президента Российской Федерации Сергея Иванова.

Благодаря национальному парку «Земля леопарда» уничтожение редчайшей кошки на планете удалось остановить, и численность вида начала расти. Сейчас специалисты насчитывают порядка 80 особей дальневосточного леопарда в дикой природе, и большая часть их обитает на территории Приморья.

Фото и nacnopm леопарда Leo 42M по имени Аман - на сайте национального парка «Землялеопарда»: $\mathrm{http} / / /$ leopardland.ru/news/3451 


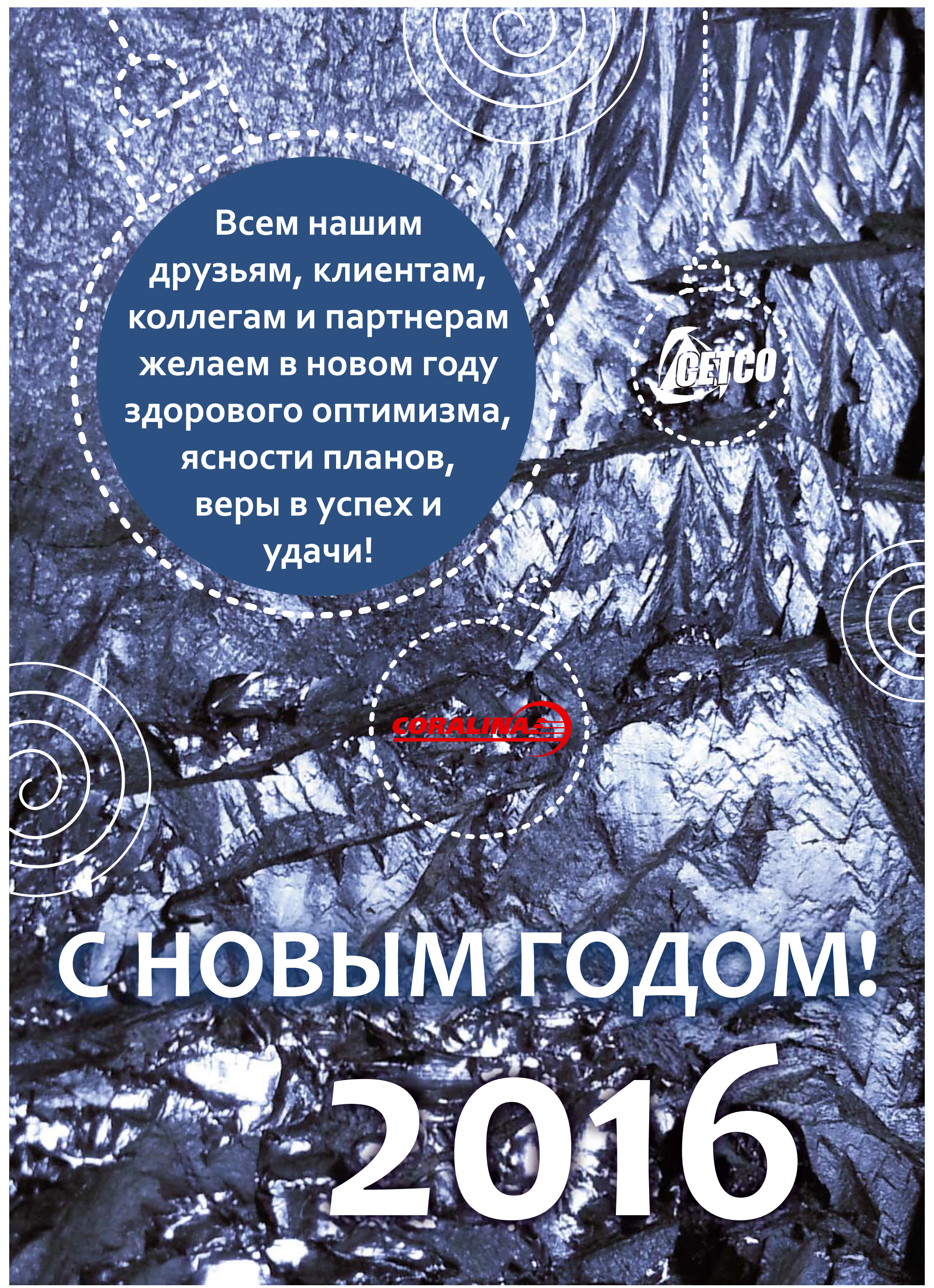

